Prepared in cooperation with the

Southwest Florida Water Management District

\title{
Hydrology, Water Budget, and Water Chemistry of Lake Panasoffkee, West-Central Florida
}

Scientific Investigations Report 2010-5237

U.S. Department of the Interior

U.S. Geological Survey 


\section{Hydrology, Water Budget, and Water Chemistry of Lake Panasoffkee, West-Central Florida}

By W. Scott McBride, Jason C. Bellino, and Amy Swancar

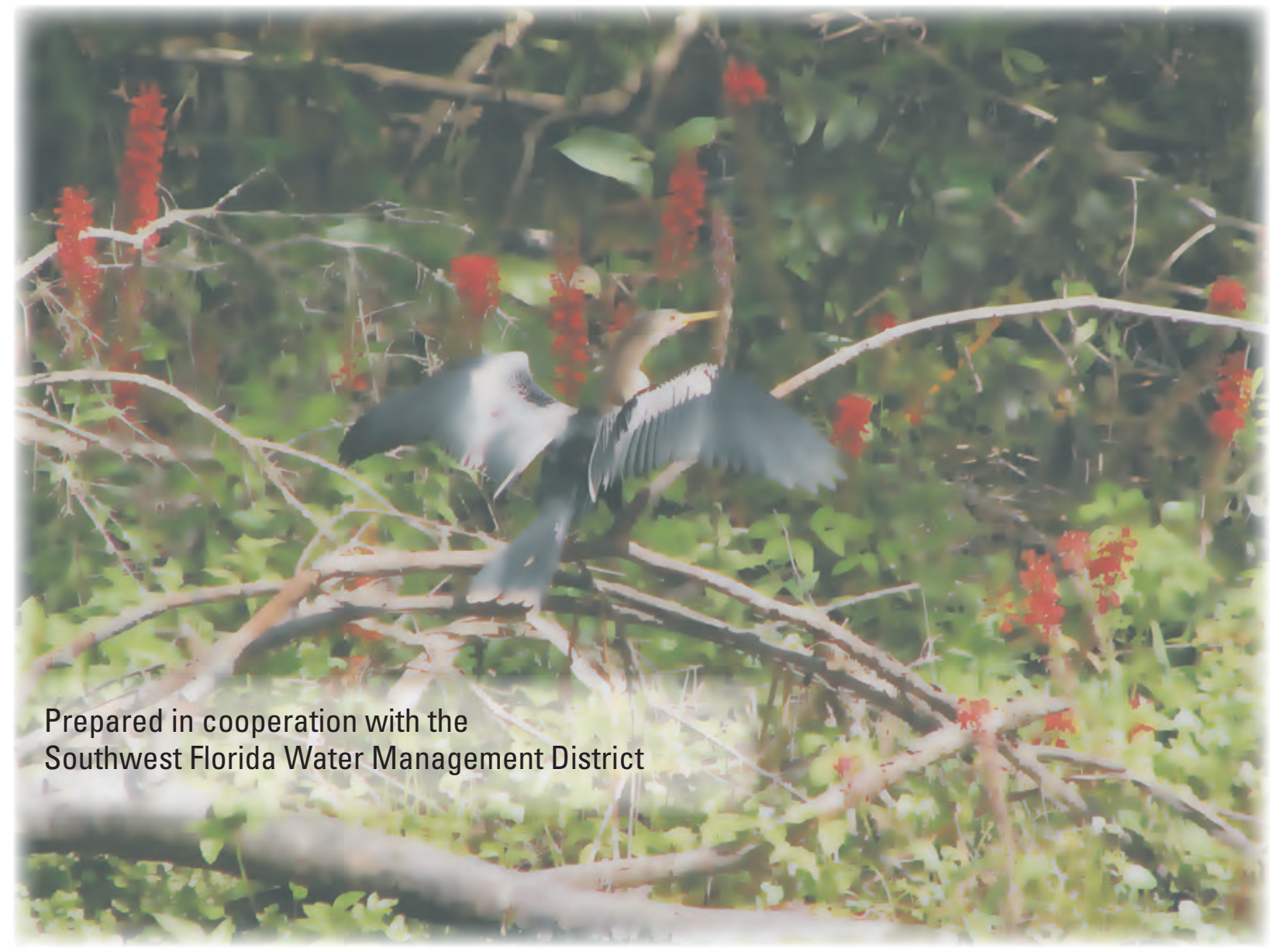

Scientific Investigations Report 2010-5237 


\title{
U.S. Department of the Interior \\ KEN SALAZAR, Secretary \\ U.S. Geological Survey \\ Marcia K. McNutt, Director
}

\section{U.S. Geological Survey, Reston, Virginia: 2011}

\author{
For more information on the USGS — the Federal source for science about the earth, its natural and living resources, \\ natural hazards, and the environment, visit http://www.usgs.gov or call 1-888-ASK-USGS \\ For an overview of USGS information products, including maps, imagery, and publications, \\ visit http://www.usgs.gov/pubprod \\ To order this and other USGS information products, visit http://store.usgs.gov
}

\begin{abstract}
Any use of trade, product, or firm names is for descriptive purposes only and does not imply endorsement by the U.S. Government.

Although this report is in the public domain, permission must be secured from the individual copyright owners to reproduce any copyrighted materials contained within this report.
\end{abstract}

Suggested citation:

McBride, W.S., Bellino, J.C., and Swancar, Amy, 2011, Hydrology, water budget, and water chemistry of Lake Panasoffkee, west-central Florida: U.S. Geological Survey Scientific Investigations Report 2010-5237, 96 p. 


\section{Contents}

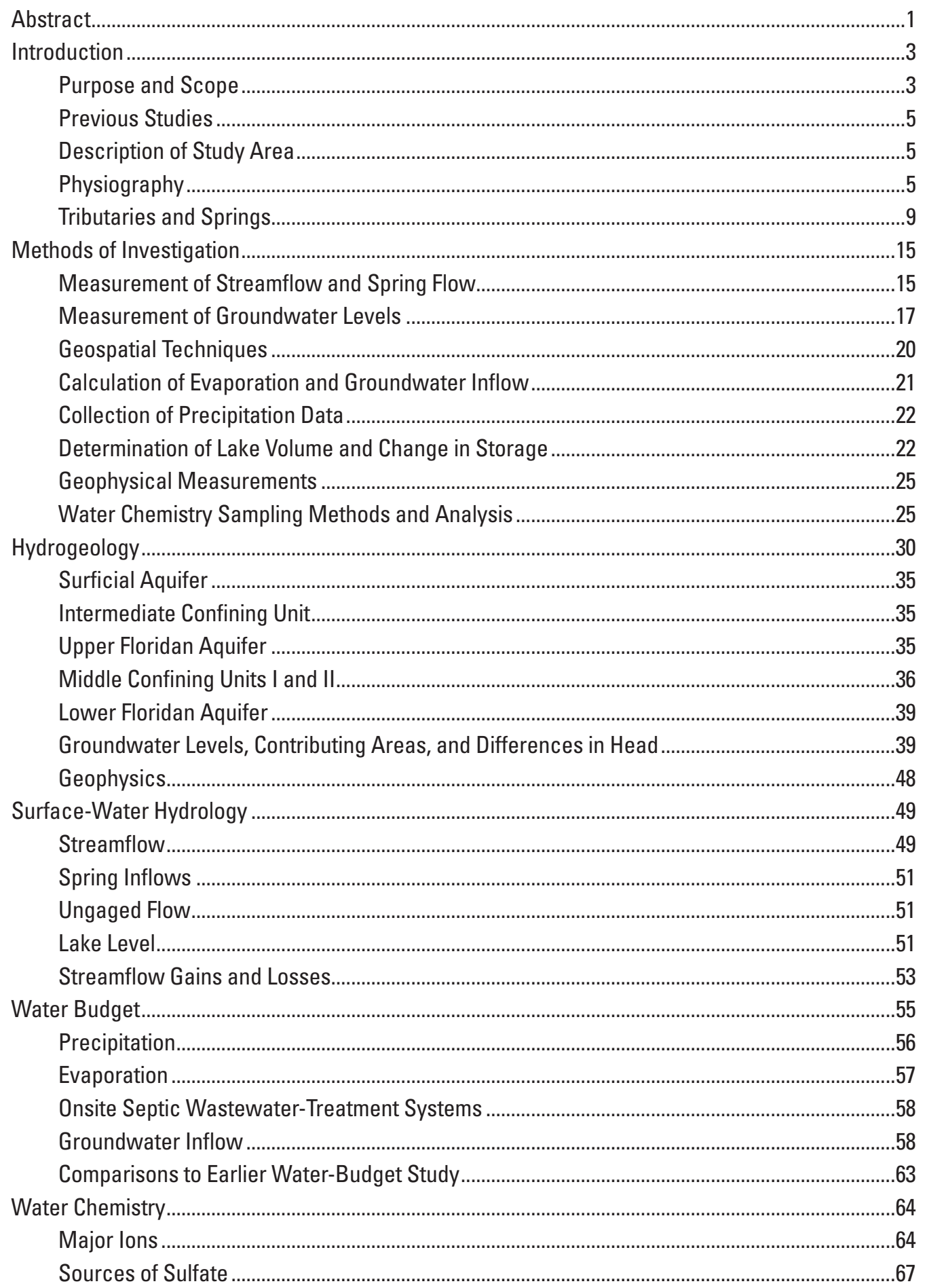




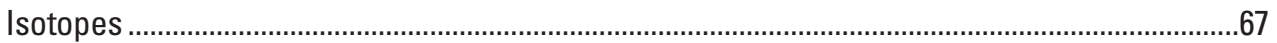

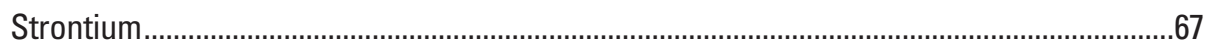

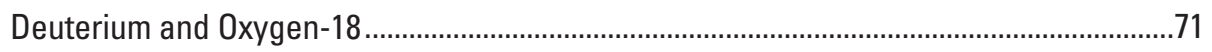

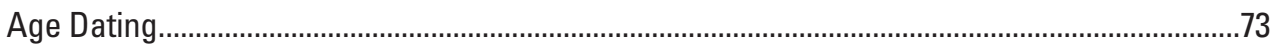

Carbon-14 and Tritium .......................................................................................................... 73

Sulfur Hexafluoride .............................................................................................................. 73

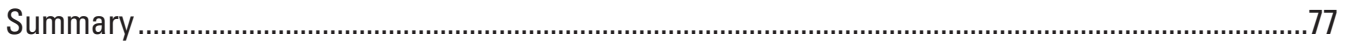

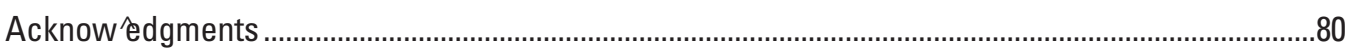

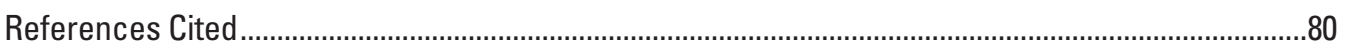

Appendix 1. Elevation of water levels in all wells used to create Upper Floridan aquifer

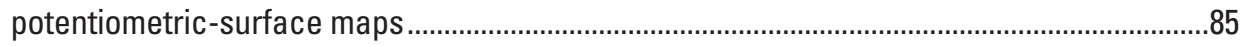

Appendix 2. Major ion, nutrient, and field parameter water-quality data from the Lake Panasoffkee study area, July 2007, and December 2008 through January 2009 ..........93

\section{Figures}

1-5. Maps showing:

1. Location of Lake Panasoffkee in west-central Florida...................................................4

2. Lake Panasoffkee surface-water drainage basin and watershed boundary ............6

3. Physiographic regions of west-central Florida ............................................................

4. Lake regions of north-central Florida ..........................................................................8

5. Location of springs, spring complexes, and sinks in the Lake Panasoffkee

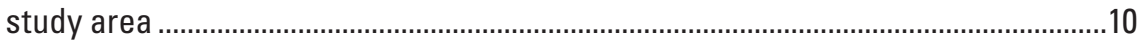

6. Photograph of Fenney Spring pool ...........................................................................................11

7. Map showing location of spring vents and surface-water gaging stations near Melton's Millpond Spring Complex.........................................................................................12

8. Photograph of Maintenance Spring pool.............................................................................13

9-14. Maps showing:

9. Location of springs in the Canal Springs Complex .........................................................14

10. Location of surface-water stations in the Lake Panasoffkee study area .................16

11. Location of wells in the Lake Panasoffkee study area ................................................18

12. Location of rain gages and current and historic lake-stage gages in the

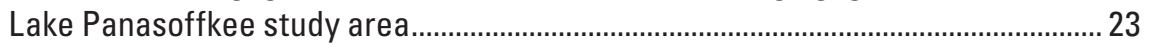

13. Lake Panasoffkee bathymetric model........................................................................... 24

14. Location of water-quality sampling stations in the Lake Panasoffkee study area

15. Chart showing relation of stratigraphic and hydrogeologic units in the Lake Panasoffkee watershed.

16. Hydrogeologic cross sections of the shallow groundwater system near Lake Panasoffkee.

17A. Map showing location of hydrogeologic section lines of the deep groundwater system in the region surrounding Lake Panasoffkee.....

17B. Hydrogeologic cross sections of the deep groundwater system in the region surrounding Lake Panasoffkee.

18. Map showing regional transmissivity of the Upper Floridan aquifer 
19. Hydrostratigraphy at four wells installed in the Lower Floridan aquifer near Lake Panasoffkee

20-25. Maps showing:

20. Areal extent of middle confining units I and II near the Lake Panasoffkee study area with reinterpretation using new hydrogeologic information 40

21. Regional groundwater flow system in the Upper Floridan aquifer, September 2007

22. Generalized potentiometric surface of the Upper Floridan aquifer in the Lake Panasoffkee study area during May 2007 and September 2007. 43

23. Generalized potentiometric surface of the Upper Floridan aquifer in the Lake Panasoffkee study area during May 2008 and September 2008.

24. Areas of recharge and discharge potential between the surficial aquifer and the Upper Floridan aquifer in the Lake Panasoffkee study area for May 2007 and September 2007.

25. Areas of recharge and discharge potential between the surficial aquifer and the Upper Floridan aquifer in the Lake Panasoffkee study area for May 2008 and September 2008

26-27. Graphs showing:

26. Difference in hydraulic head between the surficial aquifer and Upper Floridan aquifer near Lake Panasoffkee LP-6 and Wysong Dam well nests, Big Jones Creek and Little Jones Creek well nests, and LP-4 and LP-5 well nests, October 2006 through September 2008.

27. Lake stage and discharge at Pana Vista Lodge, October 2006 through September 2008.

28. Map showing relative flow contributions from each stream reach to total streamflow during four seepage runs, December 2007 through September 2008 .54

29. Graphs showing hydraulic head data for Shady Brook and Outlet River, October 2006 through September 2008. .55

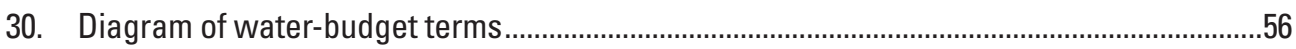

31. Graph showing monthly total rainfall in the Lake Panasoffkee watershed from October 2006 through September 2008 compared to the average monthly rainfall measured at the National Climatic Data Center station at Inverness, Florida, October 1930 through September 2008. .57

32. Map showing location of onsite septic wastewater-treatment systems within 100 meters of Lake Panasoffkee or canals

33. Graph showing summary of monthly water-budget data for Lake Panasoffkee during water years 2007 through 08

34. Trilinear diagram showing water types from water-quality samples collected in the Lake Panasoffkee watershed during July 2007 and December 2008 through January 2009

35-36. Graphs showing relation between:

35. Strontium isotope ratios and the reciprocal of the strontium concentration in water samples from the Lake Panasoffkee study area for July 2007 and December 2008 through January 2009

36. Deuterium and oxygen isotope data in the Lake Panasoffkee study area for July 2007 and December 2008 through January 2009

37. Diagram showing generalized conceptual model of the Lake Panasoffkee

watershed based on geochemical analyses. 


\section{Tables}

1. Location and name of springs in the Lake Panasoffkee study area ...........................................11

2. Location of surface-water stations in the Lake Panasoffkee study area ...................................17

3. Additional wells in the Lake Panasoffkee study area used to augment regional potentiometric-surface and water-table maps

4. Location of water-quality sampling stations in the Lake Panasoffkee study area 27

5. Elevation of land-surface datum, total depth, and depth to various formations for selected wells used in the construction of hydrogeologic cross sections

6. Average monthly surface-water discharge and total volume of monthly discharge to and from Lake Panasoffkee, April 2006 through September 2008

7. Summary of measured discharge at spring and surface-water stations in the Lake Panasoffkee study area during four seepage runs from December 2007 through September 2008

8. Monthly rainfall statistics for the Lake Panasoffkee watershed for water years 2006 through 2008 compared to the average monthly rainfall at Inverness, Florida, 1930 through 2008

9. Summary of energy-budget data for Lake Panasoffkee from October 2006 through September 2008.

10. Summary of monthly water-budget data for Lake Panasoffkee during water years 2007 through 2008

11. Comparison of the May 1992 through April 1993 and May 2007 through April 2008 Lake Panasoffkee water budgets.

12. Strontium, hydrogen, and oxygen isotope data collected from select groundwater, surface-water, and spring sites in the Lake Panasoffkee study area, July 2007 and December 2008 through January 2009

13. Carbon and tritium isotope data with adjusted carbon-14 groundwater data collected from select groundwater sites in the Lake Panasoffkee study area, December 2008

14. Mean concentrations, mean calculated atmospheric mixing ratios, mean piston flow model years of sulfur hexafluoride data and dissolved gas data in groundwater in the Lake Panasoffkee study area, December 2008 through January 2009 


\section{Conversion Factors}

\begin{tabular}{|c|c|c|}
\hline Multiply & By & To obtain \\
\hline \multicolumn{3}{|c|}{ Length } \\
\hline inch (in.) & 2.54 & centimeter $(\mathrm{cm})$ \\
\hline foot $(\mathrm{ft})$ & 0.3048 & meter $(\mathrm{m})$ \\
\hline mile (mi) & 1.609 & kilometer (km) \\
\hline \multicolumn{3}{|c|}{ Area } \\
\hline acre & 0.004047 & square kilometer \\
\hline square mile $\left(\mathrm{mi}^{2}\right)$ & 2.590 & square kilometer $\left(\mathrm{km}^{2}\right)$ \\
\hline \multicolumn{3}{|c|}{ Volume } \\
\hline gallon (gal) & 3.785 & liter $(\mathrm{L})$ \\
\hline million gallons (Mgal) & 3,785 & cubic meter $\left(\mathrm{m}^{3}\right)$ \\
\hline cubic foot $\left(\mathrm{ft}^{3}\right)$ & 0.02832 & cubic meter $\left(\mathrm{m}^{3}\right)$ \\
\hline \multicolumn{3}{|c|}{ Velocity } \\
\hline inch per day (in/d) & 0.0254 & meter per day $(\mathrm{m} / \mathrm{d})$ \\
\hline inch per year (in/yr) & 0.0254 & meter per year (m/yr) \\
\hline \multicolumn{3}{|c|}{ Flow rate } \\
\hline cubic foot per second $\left(\mathrm{ft}^{3} / \mathrm{s}\right)$ & 0.02832 & cubic meter per second $\left(\mathrm{m}^{3} / \mathrm{s}\right)$ \\
\hline cubic foot per year $\left(\mathrm{ft}^{3} / \mathrm{yr}\right)$ & 0.02832 & cubic meter per year $\left(\mathrm{m}^{3} / \mathrm{yr}\right)$ \\
\hline gallon per day (gal/d) & 0.003785 & cubic meter per day $\left(\mathrm{m}^{3} / \mathrm{d}\right)$ \\
\hline \multicolumn{3}{|c|}{ Pressure } \\
\hline millibar (mb) & 0.01450 & pound per square inch $\left(\mathrm{lb} / \mathrm{in}^{2}\right)$ \\
\hline \multicolumn{3}{|c|}{ Energy flux density } \\
\hline $\begin{array}{l}\text { calories per square centimeter per day } \\
\qquad\left(\mathrm{cal} / \mathrm{cm}^{2} / \text { day }\right)\end{array}$ & 0.04187 & megajoules per square meter $\left(\mathrm{Mj} / \mathrm{m}^{2}\right)$ \\
\hline \multicolumn{3}{|c|}{ Transmissivity * } \\
\hline foot squared per day $\left(\mathrm{ft}^{2} / \mathrm{d}\right)$ & 0.09290 & meter squared per day $\left(\mathrm{m}^{2} / \mathrm{d}\right)$ \\
\hline
\end{tabular}

*Transmissivity: The standard unit is cubic foot per day per square foot times foot of aquifer thickness [(ft $\left.\left.\mathrm{ft}^{3} \mathrm{~d}\right) / \mathrm{ft}^{2}\right] \mathrm{ft}$. In this report, the mathematically reduced form, foot squared per day $\left(\mathrm{ft}^{2} / \mathrm{d}\right)$, is used for convenience.

Temperature in degrees Celsius $\left({ }^{\circ} \mathrm{C}\right)$ may be converted to degrees Fahrenheit $\left({ }^{\circ} \mathrm{F}\right)$ as follows: ${ }^{\circ} \mathrm{F}=\left(1.8 \times{ }^{\circ} \mathrm{C}\right)+32$

Temperature in degrees Fahrenheit $\left({ }^{\circ} \mathrm{F}\right)$ may be converted to degrees Celsius $\left({ }^{\circ} \mathrm{C}\right)$ as follows: ${ }^{\circ} \mathrm{C}=\left({ }^{\circ} \mathrm{F}-32\right) / 1.8$

Vertical coordinate information is referenced to the National Geodetic Vertical Datum of 1929 (NGVD 29).

Elevation, as used in this report, refers to distance above the vertical datum.

Specific conductance is given in microsiemens per centimeter at 25 degrees Celsius $\left(\mu \mathrm{S} / \mathrm{cm}\right.$ at $\left.25^{\circ} \mathrm{C}\right)$. 


\section{Acronyms and Additional Abbreviations}

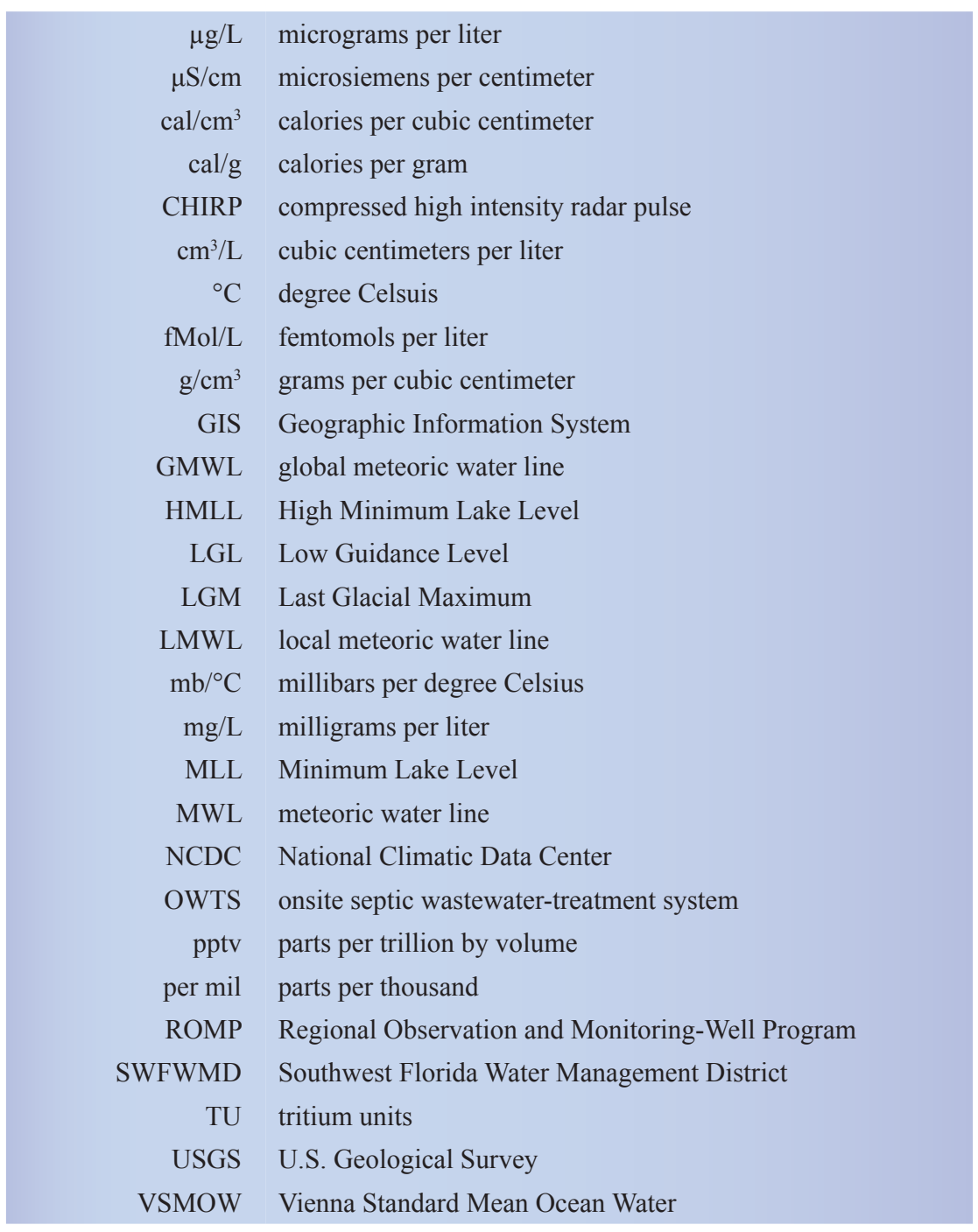




\title{
Hydrology, Water Budget, and Water Chemistry of Lake Panasoffkee, West-Central Florida
}

\author{
By W. Scott McBride, Jason C. Bellino, and Amy Swancar
}

\section{Abstract}

A study of Lake Panasoffkee and the surrounding watershed was conducted between October 2005 and September 2009 to gain a better understanding of how this large lake fits within the regional hydrogeologic setting of west-central Florida. Lake Panasoffkee is part of the headwaters of the Withlacoochee River and has a major influence on the hydrology and ecology of that basin. The study defined the interaction between surface water and groundwater, and the magnitude of lake evaporation and groundwater inflow to the lake and how these relate to the Lake Panasoffkee water budget. Geochemical and isotopic analyses were used with water-budget results to describe water sources for the lake.

Lake Panasoffkee, the underlying surficial aquifer, and the Floridan aquifer system are hydraulically connected. An area of focused groundwater-discharge potential, where groundwater levels are higher than surface-water levels, is present beneath Lake Panasoffkee and extends several miles northwest and southeast of the lake. Although the size and intensity of the discharge area varied with the seasons and with hydrologic conditions, discharging conditions remained constant throughout the study period.

The sandy uplands farther northeast and southeast of Lake Panasoffkee showed the greatest potential for surfacewater to groundwater recharge within the study area. The Lake Panasoffkee watershed lacks a well-developed surface-water drainage system because rainfall rapidly infiltrates the sandy soils in the uplands and recharges the surficial aquifer. The intermediate confining unit is discontinuous in the study area, but even in areas where the confining unit is present, there is a well-developed internal drainage system that compromises the integrity of the unit. The internal drainage system consists of an interconnected network of karst features that includes sinkholes, fissures, and conduits. The discontinuous intermediate confining unit and internal drainage features allow the surficial aquifer to rapidly recharge the Upper Floridan aquifer in recharge areas.

Little Jones Creek and Shady Brook were the primary contributors of surface-water flow to Lake Panasoffkee during the study period. The average monthly discharge from Little Jones Creek to Lake Panasoffkee ranged from 6.56 cubic feet per second in June 2007 to 75.8 cubic feet per second in August 2008, whereas the contribution of Shady Brook to Lake Panasoffkee ranged from 8.28 cubic feet per second in June 2007 to 59.6 cubic feet per second in September 2008. The combined flow from both tributaries accounted for 51 and 47 percent of total input from all sources during water years 2007 and 2008, respectively. The U.S. Geological Survey water year begins October $1^{\text {st }}$ and ends September $30^{\text {th }}$.

Water-budget calculations indicated that Lake Panasoffkee received 29 percent of its total inflow as groundwater inflow during the study period. Groundwater inflow is defined as diffuse flow (or discharge) from the groundwater 
system to Lake Panasoffkee through the lakebed. Monthly groundwater inflow to Lake Panasoffkee ranged from 11 to 50 percent of total inflow during the 2-year data-collection period, excluding 2 months when groundwater inflow was negligible. Comparatively, the volume of surface-water inflow for the 2-year data-collection period was 50 percent of the total inflow, and rainfall accounted for 21 percent. Lake Panasoffkee lost 21 percent of its outflow through evaporation and 79 percent through surface-water outflow. The percentage of total inflow received by Lake Panasoffkee from groundwater is not unusual among central Florida lakes, but the source and volume are atypical. A previous U.S. Geological Survey study showed that most lakes in central Florida receive groundwater inflow from the surficial aquifer, but Lake Panasoffkee primarily receives groundwater inflow from the Upper Floridan aquifer. The large volume of groundwater inflow also is unusual for a lake the size of Panasoffkee, which received 1.4 billion cubic feet of groundwater inflow in water year 2008. In addition, the groundwater flow system also is the source of much of the surface-water flow to Lake Panasoffkee. Four synoptic streamflow measurements completed between December 2007 and September 2008 determined that 60 to 78 percent of the total surfacewater inflow to Lake Panasoffkee during baseflow conditions originated from spring discharge.

The Floridan aquifer system contributes water to, and interacts with, the surface-water system and the surficial aquifer in the Lake Panasoffkee watershed. In the study area, the Floridan aquifer system consists of the Upper Floridan aquifer and the Lower Floridan aquifer, separated by two confining units, middle confining unit I and middle confining unit II. The distribution of the two middle confining units has substantial effect on the availability of potable groundwater in the study area. Middle confining unit I is shallower and leaky and found mostly east of the lake. Middle confining unit II is deeper, less permeable, and found mostly west of the lake. Both confining units are found south of the lake.

Water samples were collected in July 2007 and December 2008 through January 2009 from Lake Panasoffkee, selected tributaries and springs that flow into Lake Panasoffkee, and groundwater wells installed in the surficial, Upper Floridan, and Lower Floridan aquifers in the Lake Panasoffkee watershed. Every water sample collected in the study area was classified either as a calcium-bicarbonate, calcium-sulfate, or mixed calcium-bicarbonate/calcium-sulfate water type. Calcium-bicarbonate type waters form where groundwater dissolves the carbonate limestone of the shallow Upper Floridan aquifer. Calcium-sulfate type waters form through the dissolution of the mineral gypsum; geochemical mass-balance modeling performed in a previous U.S. Geological Survey study of the area indicated that the source of the gypsum (and the high sulfate water) is likely found near the base of the Upper Floridan aquifer. The mixed-water type is found in areas where the calcium-sulfate type water upwells from this unit into the shallow Upper Floridan aquifer, where it mixes with calcium-bicarbonate type water.
The calcium-sulfate and mixed calcium-bicarbonate/ calcium-sulfate type waters were found in samples from Lake Panasoffkee and from the groundwater system south and southwest of Lake Panasoffkee during the 2007 sampling event, but were only found in samples from the groundwater system during the 2008-09 sampling event. The latter sampling event followed a wet period when surface-water levels were higher and aquifer levels in the surficial and Upper Floridan aquifers had recovered slightly from earlier severe drought conditions.

Surface-water and groundwater samples that were analyzed for strontium isotope content confirmed that groundwater from the Upper Floridan aquifer interacts with both the surficial aquifer and surface waters within the Lake Panasoffkee watershed. Strontium isotope data indicated that all of the sampled sites were affected by water from the Upper Floridan aquifer, with the exception of one surficial aquifer site during each sampling event. The observed strontium-87/ strontium-86 ratios of the water samples were between 0.7077 and 0.7085 , which is consistent with the range of strontium isotope ratios found in the Upper Floridan aquifer within the Ocala Limestone and Avon Park Formation.

Water samples analyzed for the stable isotopes of hydrogen and oxygen confirm that rainfall is the primary source of groundwater recharge within the Lake Panasoffkee watershed. Water samples collected from Lake Panasoffkee and its surface-water outflow stream were isotopically enriched from evaporation, but the majority of the groundwater and spring isotope data resemble that of isotopically depleted rainfall, indicating that the watershed drainage is primarily internal. Water samples from some of the deepest wells in the study area, installed in both the Upper and Lower Floridan aquifers, indicate slight isotopic enrichment of hydrogen and oxygen isotopes compared to shallower groundwater. This is probably not an indication that these waters underwent enrichment before recharge, but that they contain a fraction of water recharged during the Last Glacial Maximum. Groundwater deep in the Upper Floridan aquifer is part of a regional flow system that was recharged thousands of years ago.

Deeper, older, and more mineralized groundwater flows upward into shallower aquifers on the west side of Lake Panasoffkee but not on the east side. Adjusted carbon-14 isotope data collected from a 240-foot deep well installed in the Avon Park Formation west of Lake Panasoffkee indicate water that was recharged about 23,485 to 26,455 years before present. Water from two wells at the same location but at different depths 7 miles east of Lake Panasoffkee was younger. Water from the 338-foot-deep Upper Floridan aquifer well installed in both the Ocala Limestone and Avon Park Formation recharged about 7,022 to 7,579 years before present, whereas water from the 1,000-foot-deep Lower Floridan aquifer well installed in the Avon Park Formation below middle confining unit I recharged about 8,703 to 9,413 years before present. 
Lake Panasoffkee is located near the western extent of middle confining unit I and the eastern extent of middle confining unit II. Because no deep exploratory drilling has been performed in the immediate vicinity of Lake Panasoffkee, it is uncertain which of these confining units are present beneath the lake. The high concentration of sulfate and the radiocarbon age of the water sample from the well west of Lake Panasoffkee indicate that the upwelling water probably comes into contact with middle confining unit II somewhere along its flow path. Middle confining unit II is the only formation in the area with a mineral composition capable of producing the high concentration of sulfate (1,700 milligrams per liter) found in the upwelling groundwater west of Lake Panasoffkee. Because middle confining unit II is composed primarily of gypsiferous dolomite, deeply circulating groundwater flowing across, or through, this unit could produce high sulfate groundwater. Water samples from the deep Upper Floridan and Lower Floridan aquifer wells east of Lake Panasoffkee were similar to one another both chemically and in radiocarbon age. These similarities indicate that on the east side of the lake water from the Upper Floridan aquifer mixes with water from the Lower Floridan aquifer through middle confining unit I, which is leaky throughout much of its extent. In the area of these wells, the Upper Floridan aquifer recharges the Lower Floridan aquifer, whereas closer to the lake, heads reflect upward discharge conditions.

\section{Introduction}

Lake Panasoffkee is located in northwestern Sumter County, west-central Florida (fig. 1), and is the largest lake in the county as well as the third largest of about 1,800 lakes in west-central Florida (Lake Panasoffkee Restoration Council, 2008). The area surrounding the lake is predominately rural, with nearly 160,000 acres of land countywide dedicated to agriculture (U.S. Department of Agriculture, 2007). The most highly developed land in the study area is located along the western shoreline of the lake in and near the town of Lake Panasoffkee. The original settlement of Panasoffkee was on the southern end of the lake, where older maps show its location.

The Florida Department of Environmental Protection has designated Lake Panasoffkee as an "Outstanding Florida Water." Only water bodies with exceptional recreational or ecological significance are awarded this status, which is intended to help preserve their existing water quality (Florida Department of Environmental Protection, 2009). To help protect the water quality in Lake Panasoffkee, as well as improve its ecology, the Lake Panasoffkee Restoration Council was formed in 1998. The restoration effort primarily involved dredging the lake bottom to remove sediments and emergent aquatic vegetation, and was completed in 2009.

Water managers and local residents have expressed concern that population growth in the Lake Panasoffkee watershed could affect local groundwater resources (Southwest
Florida Water Management District, 2000). In the past, development of groundwater resources in some parts of Florida was poorly managed because growth was rapid and unplanned. Groundwater is susceptible to contamination in the Lake Panasoffkee watershed and other parts of Florida because of the karstic terrain. Karst features, such as sinkholes, conduits, and swallets, allow surface water to recharge directly to the Upper Floridan aquifer without filtering through the sands of the surficial aquifer. In addition to its filtering capacity, the surficial aquifer supports many microbial and geochemical reactions that break down potentially harmful contaminants before they reach the Upper Floridan aquifer below.

Previous studies have already shown that a hydraulic connection is present between the surface- and groundwater systems in the Withlacoochee River Basin, which includes Lake Panasoffkee (Trommer and others, 2009). In this and other hydraulically connected systems, excessive groundwater withdrawals can result in surface-water drawdowns. As part of the headwaters of the Withlacoochee River, Lake Panasoffkee affects the hydrology and ecology of the river. A better understanding of the interaction between groundwater and surface water and how this relates to Lake Panasoffkee and the Withlacoochee River is essential to water managers for the sound development and management of local water resources, especially as demand for freshwater increases.

In October 2005, the U.S. Geological Survey (USGS) began a cooperative study with the Southwest Florida Water Management District (SWFWMD) to gain a better understanding of the surface-water hydrology, groundwater interactions, water budget, and geochemistry of the Lake Panasoffkee watershed. This study provides information that can be used to better understand spring flow, streamflow, and groundwater levels as future groundwater supplies are developed in the Lake Panasoffkee watershed. Results of the study also provide important information to more effectively manage the surface- and groundwater resources of the Lake Panasoffkee watershed as one integrated system. Studies that include surface- and groundwater interaction, water-supply watersheds, and source-water protection information are a high priority of the USGS Federal Water Cooperative Program, and the investigative methods of this study have transfer value to other watersheds located in karst areas.

\section{Purpose and Scope}

The purpose of this report is to document the surfacewater hydrology, groundwater interactions, water budget, and geochemistry of the Lake Panasoffkee watershed. The interaction between groundwater and Lake Panasoffkee is evaluated using multiple approaches, and the water budget of the lake is refined by incorporating onsite measurement of lake evaporation rates. Geochemical analyses are used to help describe the interaction of surface water and groundwater in the watershed. 


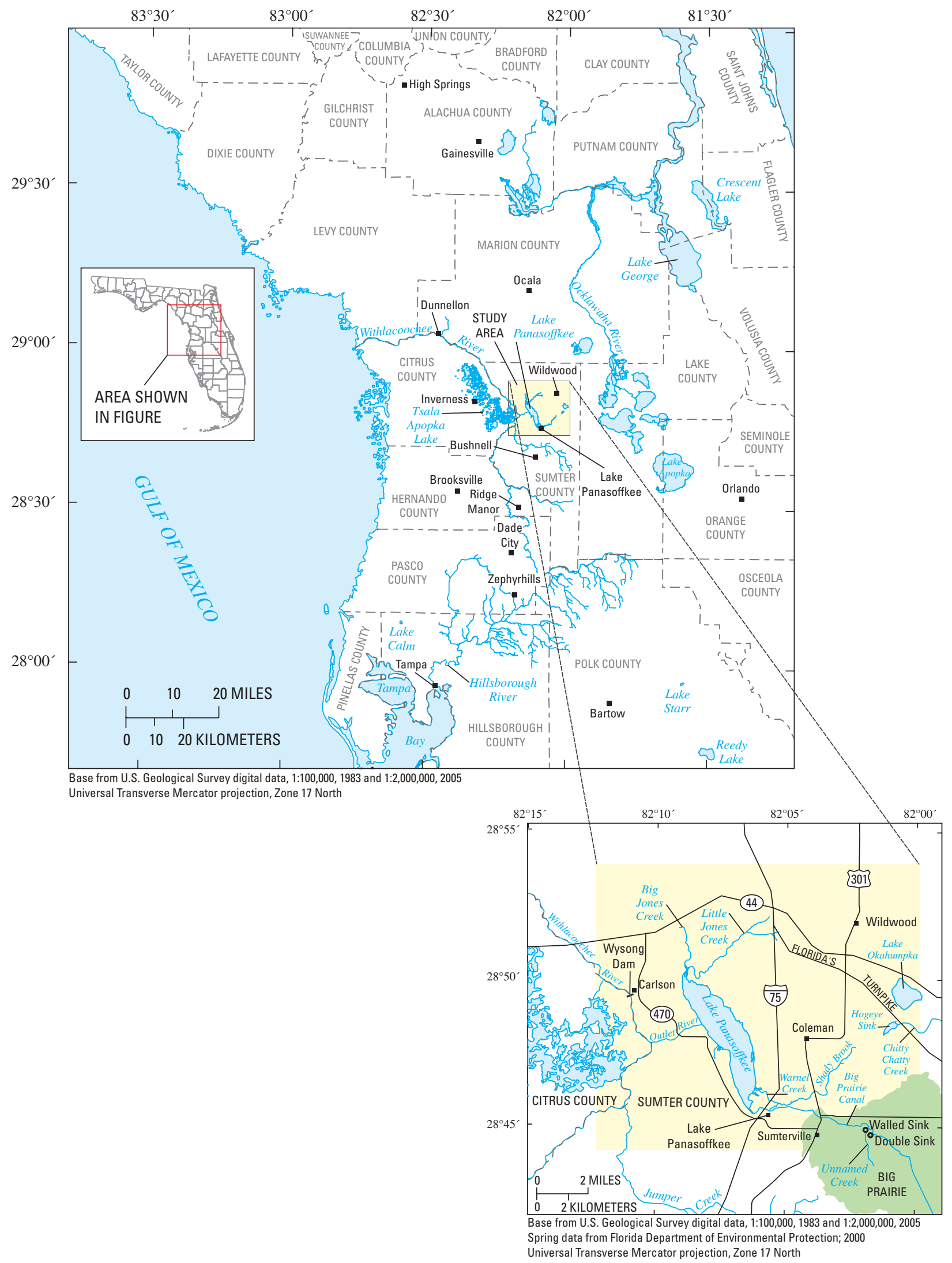

Figure 1. Location of Lake Panasoffkee in west-central Florida. 
Hydrologic and geologic data were collected during the course of the 3.5-year study (April 2006-September 2009), and historical data were compiled from the records of the USGS and the SWFWMD, and from previously published reports. The study required the design and implementation of a surface-water and groundwater level monitoring network, the installation of an open-water evaporation station, and the measurement of surface-water flows and spring flows to quantify the volume of flow reaching Lake Panasoffkee. Surface-water and spring-flow measurements also were used to quantify the exchange rate of surface water and groundwater along stream reaches. Water samples were collected from select surface-water sites, springs, and groundwater wells to define the geochemistry of the area. Seismic-reflection surveys were performed to determine the depth and thickness of geologic units beneath the lake. Continuous groundwaterlevel data were collected in the surficial and Upper Floridan aquifers to define groundwater flow patterns in the watershed.

Although Lake Panasoffkee restoration efforts by the SWFWMD were in progress during this study (Lake Panasoffkee Restoration Council, 2008), the effects of these restoration efforts were considered in data collection and analysis. For example, the water-budget calculations were affected by the removal of sediment from the lake bottom, because large volumes of water were removed with the sediments. This pumpage from the lake was accounted for as a term in the water-budget calculation because accurate records of pumpage were maintained by the dredge operators.

The data in this report are typically discussed in terms of water years. A water year is the 12-month period from October 1 through September 30, and the year is designated by the calendar year in which it ends; for example, October 1 , 2008, through September 30, 2009, constitutes water year 2009.

\section{Previous Studies}

The geology and geomorphology of the Lake Panasoffkee area were described by White $(1958,1970)$ and Campbell (1989). The hydrogeologic framework of the Floridan aquifer system in the Lake Panasoffkee region was defined by Miller (1986). Arthur and others (2001) created lithostratigraphic and hydrostratigraphic cross sections that dissect the Lake Panasoffkee area. The hydrology and hydrogeology of the area have been studied by Taylor (1977), Greiner Engineering Sciences (1978), Adams (1985), Ryder (1985), and Camp and Barcelo (1988). Bays and Crisman (1981) evaluated the water quality of Lake Panasoffkee. CH2M Hill (1995) created a water and nutrient budget for Lake Panasoffkee. Belanger and others (1993) determined the thickness of the bottom sediments in Lake Panasoffkee and analyzed the sediments for chemical composition. Sources of sediment and rates of sediment accumulation in Lake Panasoffkee were evaluated by Belanger and others (1995) using lead-210 as an isotopic dating tool. Sacks (1996) studied the geochemistry and isotopic composition of groundwater near Lake Panasoffkee with special emphasis on potential sources of unusually high sulfate concentrations near the lake. Elliot and others (1998) studied the quality of groundwater around Lake Panasoffkee and calculated the nutrient load to the lake contributed by spring flow. The water quality and hydrology of springs in the Lake Panasoffkee basin have been described by Champion and Starks (2001). Brenner and others (2006) studied the role of submerged aquatic vegetation in the sedimentation of organic matter and phosphorous using carbon/nitrogen ratios and stable isotopes of carbon and nitrogen in Lake Panasoffkee.

\section{Description of Study Area}

The study area primarily encompasses the land around Lake Panasoffkee that directly contributes surface-water runoff to the lake (fig. 2), and is referred to herein as the Lake Panasoffkee watershed (as defined by Taylor, 1977). The Lake Panasoffkee watershed differs from the Lake Panasoffkee basin, which is a much larger area that could theoretically contribute surface-water flow to Lake Panasoffkee based on physiography, but does not because of the karst terrain and its well developed internal drainage system. Some of the analyses performed in this study extend beyond the Lake Panasoffkee watershed boundary, such as the calculations to determine the groundwater contribution area to Lake Panasoffkee, but data were primarily collected inside the watershed boundary.

A vast floodplain swamp is situated between the eastern shoreline of Lake Panasoffkee and Interstate-75 (I-75). The SWFWMD purchased nearly 10,000 acres of the swamp during the 1990s. This purchase helped protect the water quality in Lake Panasoffkee by ensuring the preservation of the land in its undeveloped state (Kelly, 1996).

All four of the tributaries to Lake Panasoffkee (Big Jones Creek, Little Jones Creek, Shady Brook, and Warnel Creek; figs. 1 and 2) traverse the SWFWMD lands for some or all of their lengths. At present, most of this property is managed jointly by the SWFWMD and the Florida Fish and Wildlife Conservation Commission as the Lake Panasoffkee Wildlife Management Area (Kelly, 1996).

The Lake Panasoffkee area has warm, humid summers and cool, dry winters associated with a subtropical climate. The mean annual air temperature is about $72^{\circ} \mathrm{F}$, with summer temperatures that occasionally rise above $95^{\circ} \mathrm{F}$, and winter temperatures that occasionally fall below $32^{\circ} \mathrm{F}$ (National Climatic Data Center, 2009). The rainy season lasts from June through September, with rain events mostly in the form of intense localized thunderstorms and occasional tropical storms. Summer rains account for about 60 percent of the annual rainfall, which averages $54.26 \mathrm{in} / \mathrm{yr}$, although annual totals vary substantially between years (National Climatic Data Center, 2009). The other 40 percent of rainfall is generated by winter frontal systems, primarily from December through March. 


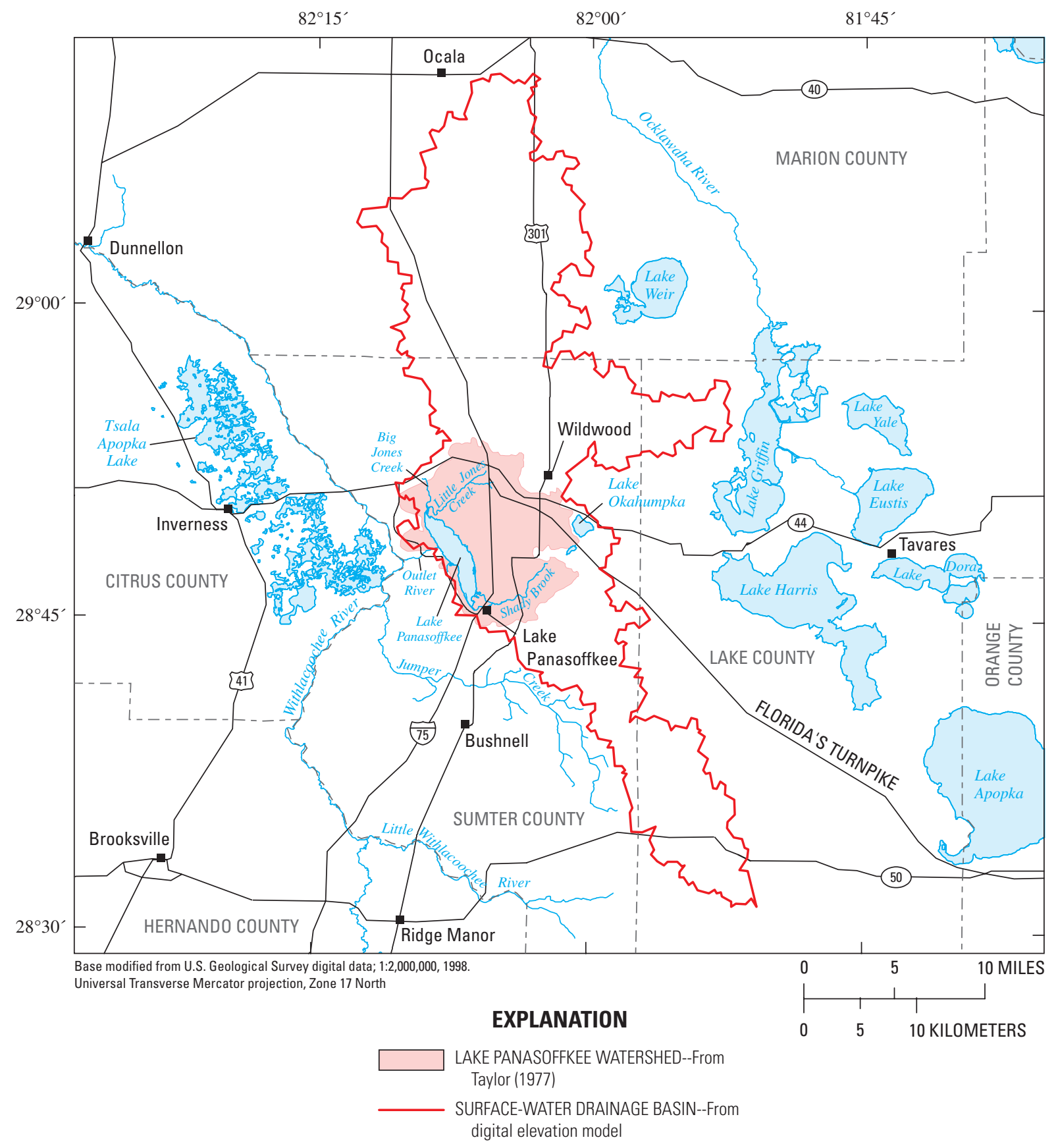

Figure 2. The Lake Panasoffkee surface-water drainage basin and watershed boundary.

\section{Physiography}

Lake Panasoffkee, the Tsala Apopka chain of lakes, and much of the Withlacoochee River are located within the Tsala Apopka Plain (fig. 3), which extends from Dunnellon south to east of Dade City. The Tsala Apopka Plain is a subregion of flat lowlands within the Western Valley physiographic region (White, 1970). The Western Valley parallels the west coast of Florida from High Springs south to Zephyrhills (figs. 1 and 3), and is bounded by the Brooksville Ridge to the west and various distinct upland areas to the east, including both the Sumter and Lake Uplands (figs. 1 and 3) (White, 1970).

White (1958) theorized that the Tsala Apopka Plain is a relict feature of a much larger lake and river system that originally flowed southward into the Hillsborough River, 


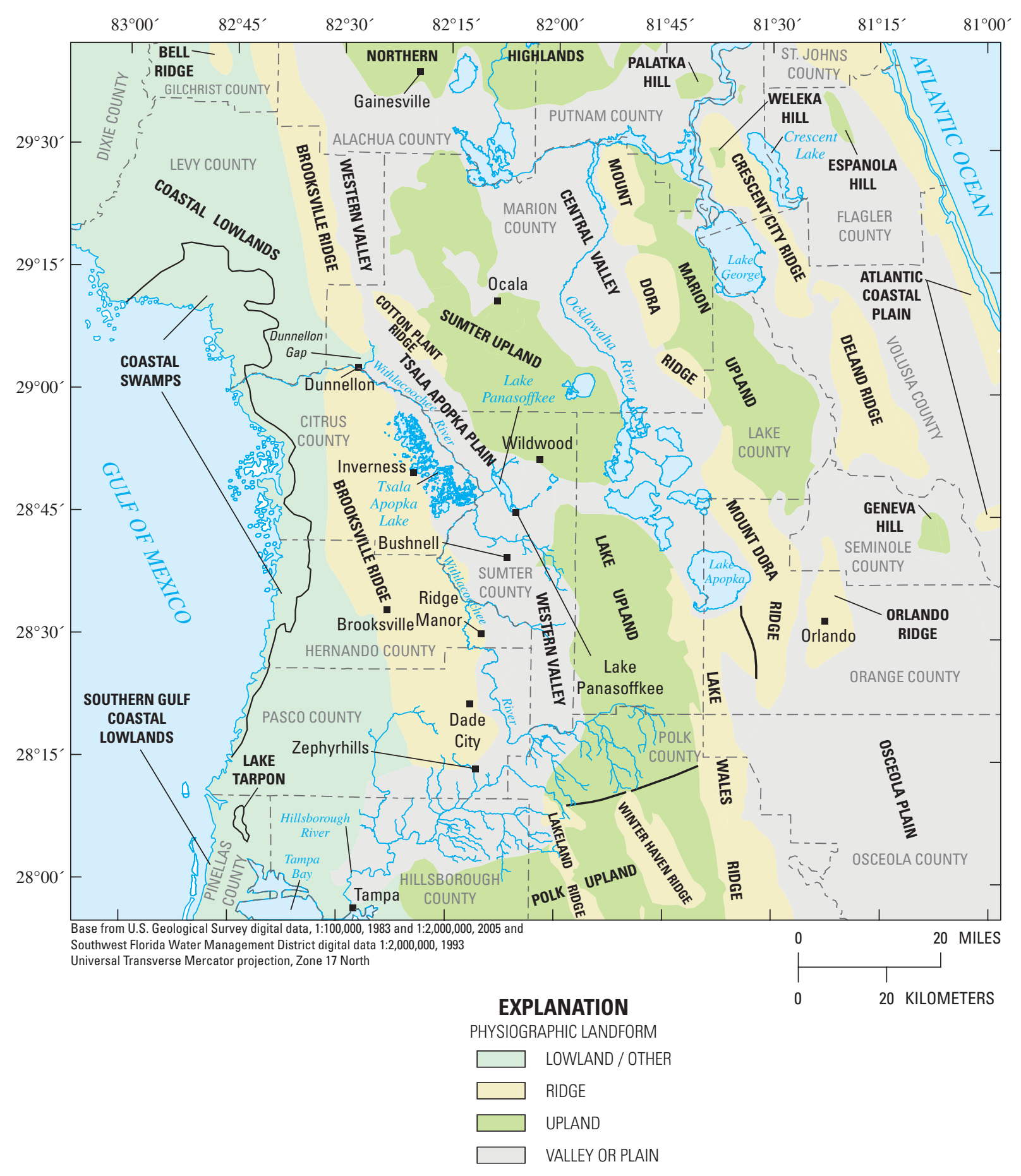

Figure 3. Physiographic regions of west-central Florida (from White, 1970).

and ultimately, into Tampa Bay. The Brooksville Ridge formed the western boundary of this large lake and river system, but as flowing groundwater dissolved the limestone bedrock along a postulated fault line, the Dunnellon Gap was formed across the Brooksville Ridge (Faulkner, 1973). The subterranean passage eventually expanded to the point where the overlying material collapsed into the void, splitting the ridge laterally and forming the gap. Surface-water flow in the river system then reversed and began flowing northward from the present-day headwaters of the Green Swamp (fig. 4) on the route of the modern-day Withlacoochee River, which flows west through the Dunnellon Gap (fig. 3) before emptying into the Gulf of Mexico (White, 1958).

The Sumter Upland and Lake Upland are northeast and southeast of Lake Panasoffkee, respectively (fig. 3), and are up to $150 \mathrm{ft}$ above NGVD 29. To the west of Lake Panasoffkee is 


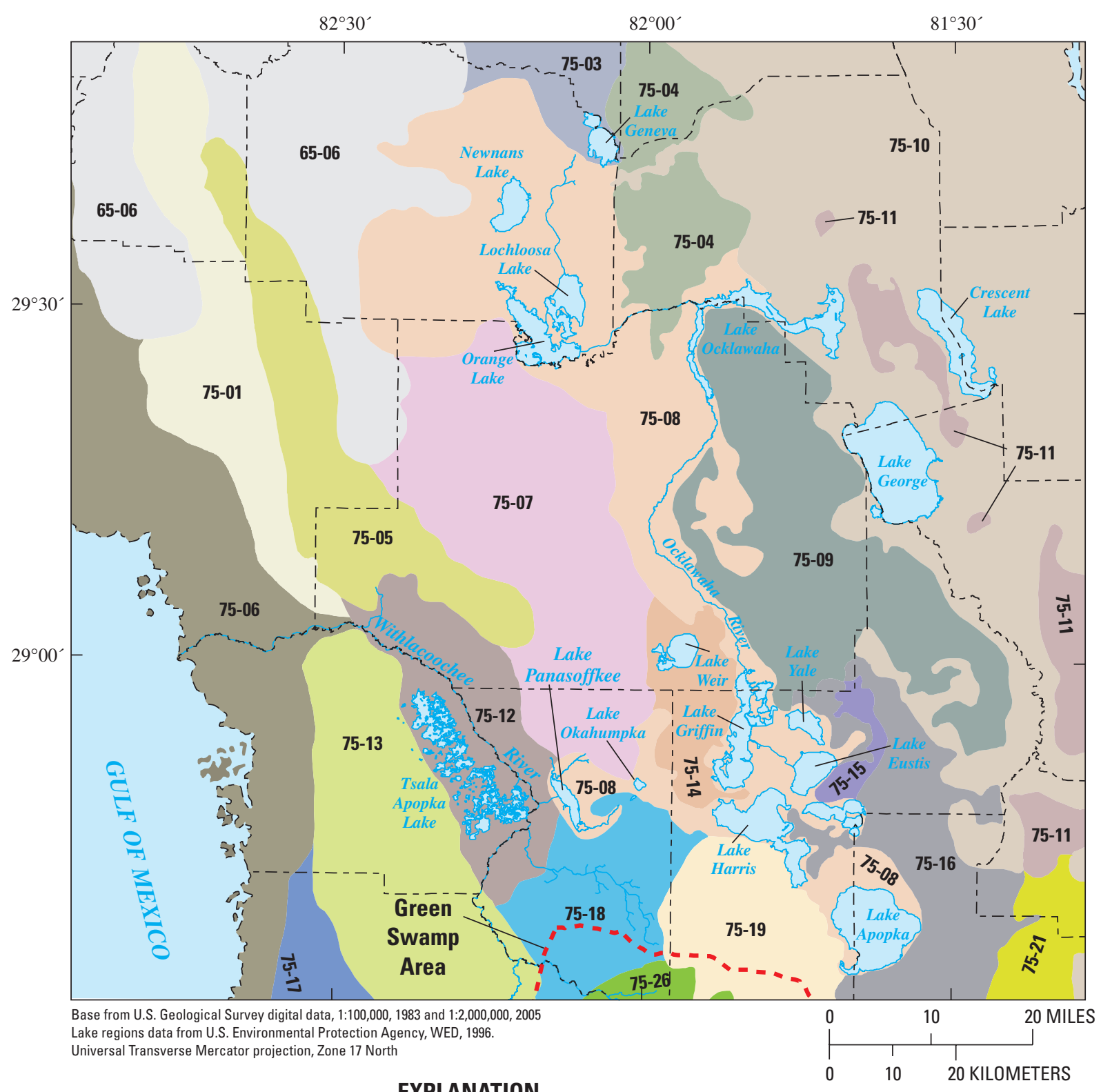

\section{EXPLANATION}

\section{LAKE REGIONS}

Regions shown are based upon water-quality characteristic classification (Griffith and others, 1997)

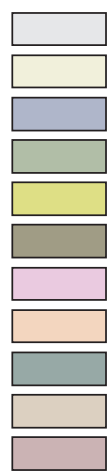
65-06 NORTHERN PENINSULA KARST PLAINS 75-01 GULF COAST LOWLANDS 75-03 UPPER SANTA FE FLATWOODS 75-04 TRAIL RIDGE 75-05 NORTHERN BROOKSVILLE RIDGE 75-06 BIG BEND KARST 75-07 MARION HILLS 75-08 CENTRAL VALLEY 75-09 OCALA SCRUB 75-10 EASTERN FLATLANDS 75-11 CRESCENT CITY/DELAND RIDGES

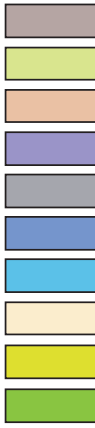
75-12 TSALA APOPKA 75-13 SOUTHERN BROOKSVILLE RIDGE 75-14 LAKE WEIR/LEESBURG UPLAND 75-15 MOUNT DORA RIDGE 75-16 APOPKA RIDGE 75-17 APOPKA UPLAND 75-18 WEBSTER DRY PLAIN 75-19 CLERMONT UPLANDS 75-21 ORLANDO RIDGE 75-26 GREEN SWAMP

Figure 4. Lake regions of north-central Florida (from Griffith and others, 1997). 
the Brooksville Ridge, which has the most irregular surface of any surface feature of comparable size in peninsular Florida. The elevation of the Brooksville Ridge is as high as $200 \mathrm{ft}$ above NGVD 29, but can vary from 70 to $200 \mathrm{ft}$ above NGVD 29 within short distances (White, 1970).

In addition to the physiographic regions described above, Florida has been further divided into lake regions (fig. 4) that reflect differences in water quality, water quantity, and hydrology (Griffith and others, 1997). Lake Panasoffkee is within the Central Valley lake region (fig. 4, region 75-08), which includes the Ocklawaha chain of lakes to the east (Lakes Apopka, Harris, Griffin, Eustis, and Yale) and three lakes to the north (Newnans Lake, Lochloosa Lake, and Orange Lake). Lake Panasoffkee lies at the western end of a conspicuous narrow offshoot of the Central Valley lake region that extends from the Ocklawaha chain of lakes into the eastern part of the Tsala Apopka lake region (region 75-12).

The lakes in the Central Valley region are typically large, shallow, and eutrophic, with abundant macrophytes or algae and low water transparency. Water chemistry varies greatly among the Central Valley group of lakes, although this variation generally reflects the broad range in mineral content of their waters (Griffith and others, 1997). Those lakes with high mineral content waters interact with a source of mineralized groundwater. Lake Panasoffkee, with a high mineral content, receives a large volume of water from the carbonate Floridan aquifer system through both spring discharge and groundwater inflow. Lakes with low mineral content water typically receive a large percentage of their inflow from rainfall or from shallow groundwater that is low in mineral content (Griffith and others, 1997).

The $360-\mathrm{mi}^{2}$ surface-water drainage basin containing Lake Panasoffkee, as defined by topographic maps, is long and narrow. The lake is situated along the west-central boundary of the basin, and is about $6 \mathrm{mi}$ long by $1.5 \mathrm{mi}$ wide (fig. 2). When the lake surface is at an elevation of $41.0 \mathrm{ft}$ above NGVD 29, it covers an area of nearly 5,700 accres, with an average depth of $7 \mathrm{ft}$ and a maximum depth of $10 \mathrm{ft}$ (Taylor, 1977; Southwest Florida Water Management District, 2006). The topographic basin trends in a northwesterly/southeasterly direction, extending from the Ocala area south to an area east of Ridge Manor (fig. 2).

The effective surface-water contribution area to Lake Panasoffkee is substantially smaller than the topographically defined basin because of internal drainage to the groundwater system. The sandy soils overlying the surficial aquifer and the lack of an effective confining unit above the Upper Floridan aquifer allow precipitation to rapidly recharge the groundwater system. Streams (and stream channels) have little opportunity to form under these conditions because surface-water runoff across the landscape is minimal.

\section{Tributaries and Springs}

Lake Panasoffkee has four tributaries, all of which except Big Jones Creek originate at springs. Although local residents have reported that springs were located along Big Jones Creek, none were discovered during this study. The inlet for both Big Jones Creek and Little Jones Creek is located at the northern end of the lake (fig. 5). Big Jones Creek is an intermittent stream that originates in a wetland south of State Road (S.R.) 44 and about 8 mi west of Wildwood. Little Jones Creek is a perennial stream that originates at Henry Green Spring (SP20, fig. 5 and table 1) on private property west of I-75. Wayne Lee Spring (SP19, fig. 5 and table 1), located on private property east of Florida's Turnpike, also forms a run that empties into Little Jones Creek about 1 mi below Henry Green Spring. An unnamed tributary to Wayne Lee Spring run originates in the I-75 median south of the I-75 and Florida's Turnpike junction. The tributary joins Wayne Lee Spring run just west of I-75. Sepulveda (2002) measured flows on the unnamed tributary (where it crosses under I-75) of 8, 5, and $3 \mathrm{ft}^{3} / \mathrm{s}$ between August 1993 and July 1994, and indicated that the flow originated from a spring. The channel at this site was mostly dry during this study, and no flow was observed when the channel was wet. Reconnaissance of the dry channel during the current study did not reveal a spring vent. The most likely source of flow in this channel is groundwater inflow when groundwater levels are above land surface.

Warnel Creek and Shady Brook discharge into the southern end of Lake Panasoffkee. Warnel Creek branches off of Shady Brook and discharges into Lake Panasoffkee northeast of where Shady Brook flows into the lake. Shady Brook originates on private property at Fenney Spring (SP18, fig. 5 and table 1), about 2 mi east of Coleman, and terminates about $5 \mathrm{mi}$ to the southwest. Fenney Spring (fig. 6) is largely undeveloped, although the surrounding banks have been eroded by cattle. Other springs that discharge into Shady Brook, in downstream order, include Blue Spring (SP17, fig. 5 and table 1), Belton's Millpond Spring Complex (SP4-SP8, fig. 5 and table 1), and Maintenance Spring (SP3, fig. 5 and table 1).

Other springs in the lake watershed that appear to discharge into Shady Brook are shown on the Wildwood USGS 7.5-minute topographic quadrangle, which incorporates most of the eastern half of the study area. All of the springs listed on the Wildwood quadrangle were investigated during the course of this study. Dixie Lime and Stone Company Spring (SP1, fig. 5 and table 1) does not directly contribute flow to Lake Panasoffkee, and was therefore not included in the study. Shady Brook Head Spring 4 (SP2, fig. 5 and table 1) was not accessible because it is located on private property and the owner could not be located. Because reconnaissance of adjacent public property did not reveal a spring run, it is unlikely that this spring contributes substantial flow to Shady Brook. Shady Brook Head Spring 3 (SP16, fig. 5 and table 1) 


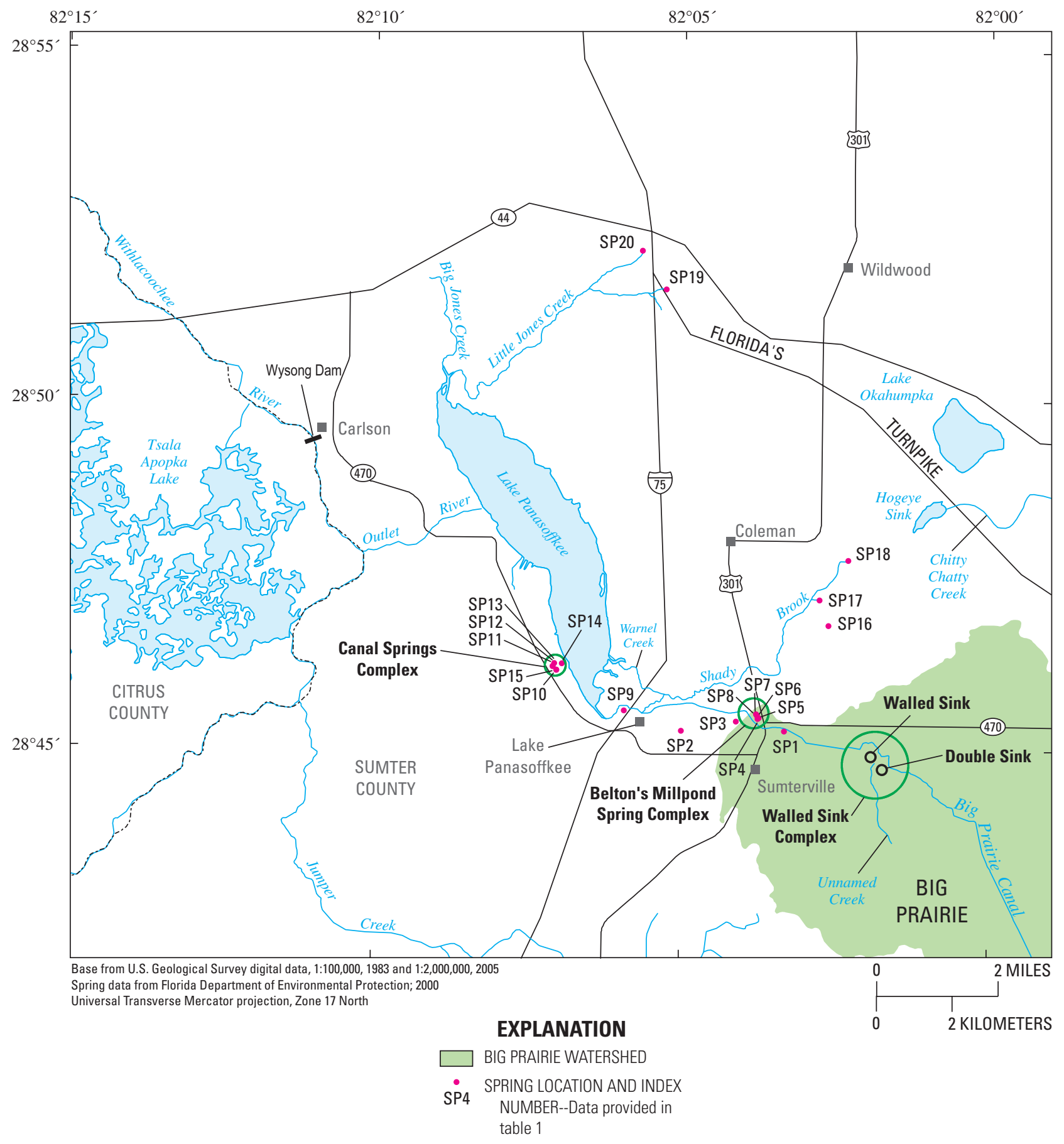

Figure 5. Location of springs, spring complexes, and sinks in the Lake Panasoffkee study area. Site identification numbers and names are given in table 1. 
Table 1. Location and name of springs in the Lake Panasoffkee study area.

[FDEP, Florida Department of Environmental Protection; n/a, not applicable]

\begin{tabular}{|c|c|c|c|c|}
\hline $\begin{array}{c}\text { Reference } \\
\text { number } \\
\text { (fig. 5) }\end{array}$ & $\begin{array}{c}\text { FDEP site } \\
\text { identification } \\
\text { number }\end{array}$ & Spring name & Latitude & Longitude \\
\hline SP1 & 284515082032301 & Dixie Lime \& Stone Co. Spring & $28^{\circ} 45^{\prime} 16^{\prime \prime}$ & $82^{\circ} 03^{\prime} 19^{\prime \prime}$ \\
\hline $\mathrm{SP} 2$ & 284515082050001 & Shady Brook Head Spring 4 & $28^{\circ} 45^{\prime} 15^{\prime \prime}$ & $82^{\circ} 05^{\prime} 00^{\prime \prime}$ \\
\hline SP3 & 284524082040501 & Belton's Millpond (Maintenance Spring) & $28^{\circ} 45^{\prime} 24^{\prime \prime}$ & $82^{\circ} 04^{\prime} 05^{\prime \prime}$ \\
\hline SP4 & 284526082034401 & Belton's Millpond Head Spring 1 & $28^{\circ} 45^{\prime} 26^{\prime \prime}$ & $82^{\circ} 03^{\prime} 44^{\prime \prime}$ \\
\hline SP5 & 284527082034301 & Belton's Millpond Head Spring 2 & $28^{\circ} 45^{\prime} 27^{\prime \prime}$ & $82^{\circ} 03^{\prime} 43^{\prime \prime}$ \\
\hline SP6 & 284528082034801 & Belton's Millpond Head Spring 2a & $28^{\circ} 45^{\prime} 28^{\prime \prime}$ & $82^{\circ} 03^{\prime} 48^{\prime \prime}$ \\
\hline SP7 & 284529082034501 & Belton's Millpond Head Spring 2b & $28^{\circ} 45^{\prime} 29^{\prime \prime}$ & $82^{\circ} 03^{\prime} 45^{\prime \prime}$ \\
\hline SP8 & 284529082034502 & Belton's Millpond Head Spring 3 -main boil & $28^{\circ} 45^{\prime} 29^{\prime \prime}$ & $82^{\circ} 03^{\prime} 45^{\prime \prime}$ \\
\hline SP9 & 284533082055401 & Big Hole (Dead Spring) & $28^{\circ} 45^{\prime} 33^{\prime \prime}$ & $82^{\circ} 05^{\prime} 55^{\prime \prime}$ \\
\hline SP10 & 284607082070101 & Canal 485 Spring 5 & $28^{\circ} 46^{\prime} 07^{\prime \prime}$ & $82^{\circ} 07^{\prime} 01^{\prime \prime}$ \\
\hline SP11 & $\mathrm{n} / \mathrm{a}$ & Canal 485a Spring 1a & $28^{\circ} 46^{\prime} 10^{\prime \prime}$ & $82^{\circ} 07^{\prime} 05^{\prime \prime}$ \\
\hline $\mathrm{SP} 12$ & 284610082070401 & Canal 485a Spring $1 \mathrm{~b}$ & $28^{\circ} 46^{\prime} 10^{\prime \prime}$ & $82^{\circ} 07^{\prime} 05^{\prime \prime}$ \\
\hline SP13 & 284612082070301 & Canal 485a Spring 2 & $28^{\circ} 46^{\prime} 13^{\prime \prime}$ & $82^{\circ} 07^{\prime} 03^{\prime \prime}$ \\
\hline SP14 & $\mathrm{n} / \mathrm{a}$ & Canal 485a Spring 3 & $28^{\circ} 46^{\prime} 13^{\prime \prime}$ & $82^{\circ} 06^{\prime} 56^{\prime \prime}$ \\
\hline SP15 & $\mathrm{n} / \mathrm{a}$ & Canal 485 Spring 4 & $28^{\circ} 46^{\prime} 07^{\prime \prime}$ & $82^{\circ} 07^{\prime} 01^{\prime \prime}$ \\
\hline SP16 & 284646082023701 & Shady Brook Head Spring 3 & $28^{\circ} 46^{\prime} 46^{\prime \prime}$ & $82^{\circ} 02^{\prime} 37^{\prime \prime}$ \\
\hline SP17 & 284708082024401 & Shady Brook Head Spring 2 (Blue Spring) & $28^{\circ} 47^{\prime} 08^{\prime \prime}$ & $82^{\circ} 02^{\prime} 44^{\prime \prime}$ \\
\hline SP18 & 284742082021901 & Fenney Spring & $28^{\circ} 47^{\prime} 42^{\prime \prime}$ & $82^{\circ} 02^{\prime} 19^{\prime \prime}$ \\
\hline SP19 & 285104082051701 & Wayne Lee Spring & $28^{\circ} 51^{\prime} 04^{\prime \prime}$ & $82^{\circ} 05^{\prime} 17^{\prime \prime}$ \\
\hline SP20 & 285138082054001 & Henry Green Spring & $28^{\circ} 51^{\prime} 38^{\prime \prime}$ & $82^{\circ} 05^{\prime} 40^{\prime \prime}$ \\
\hline
\end{tabular}

was investigated and was not flowing during August 2006. The spring vent was silted in and did not appear to have flowed for many years.

Blue Spring (SP17), also called Shady Brook Head Spring 2, is situated in a remote swamp on private property about $0.75 \mathrm{mi}$ southwest of Fenney Spring (SP18) (also called Shady Brook Head Spring 1). An undeveloped pond surrounds the Blue Spring vent, and a spring run less than $0.2 \mathrm{mi}$ in length flows west from the pond and empties into Shady Brook.

Belton's Millpond Spring Complex (SP4-SP8) is located about $0.25 \mathrm{mi}$ northwest of the intersection of U.S. 301 and S.R. 470 at Sumterville (figs. 5 and 7). The complex consists of four springs (one spring has two vents) that form a pond that flows west over a gated spillway. Maintenance Spring (SP3) is located about $0.25 \mathrm{mi}$ southwest of Belton's Millpond, and forms a circular pool (figs. 5 and 8) that overflows through a culvert pipe installed in a berm on the northwestern side of the pool. Both Belton's Millpond Spring Complex and

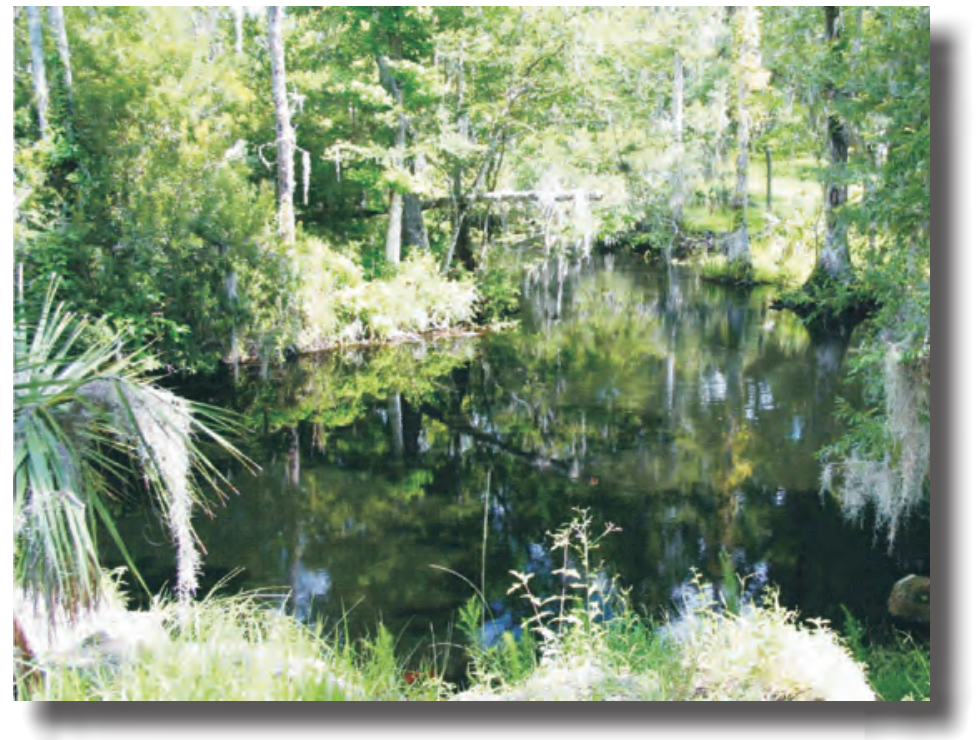

Figure 6. Fenney Spring pool; photo by W. Scott McBride. 


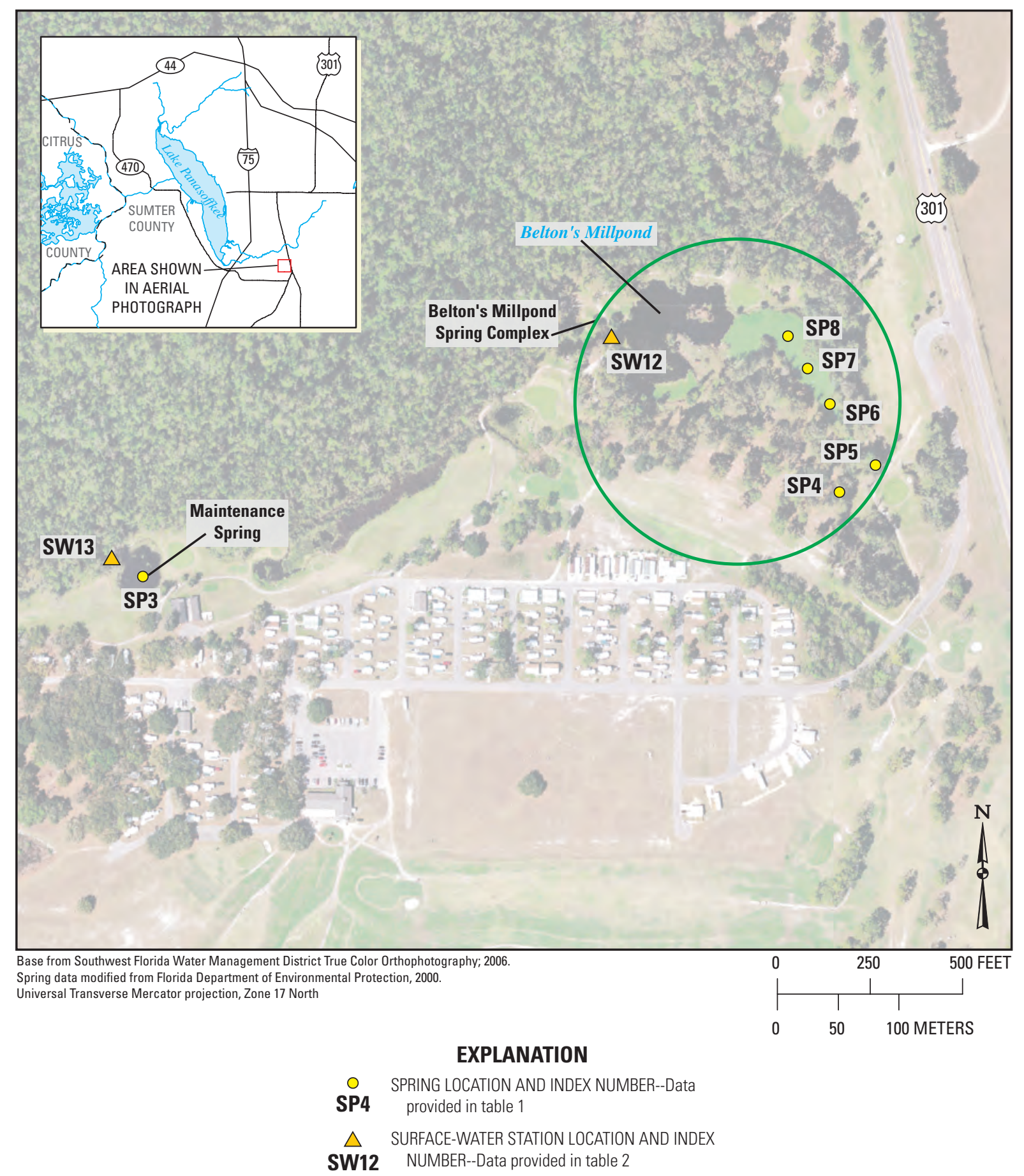

Figure 7. Location of spring vents and surface-water gaging stations near Belton's Millpond Spring Complex. Site identification numbers and names are given in tables 1 and 2.

Maintenance Spring have been substantially modified from their undeveloped states by the addition of berms to increase the size of the pools around the spring vents.

The runs formed by both Belton's Millpond and Maintenance Spring flow northwestward into a large lowland swamp south of Shady Brook near the intersection with Lake Panasoffkee. Near their respective springs, Belton's Millpond Spring run and Maintenance Spring run are well defined, but the channels quickly lose their definition as they flow through the swamp. Ultimately, water from these springs reaches Shady Brook by way of diffuse overland flow through the neighboring swamplands. 


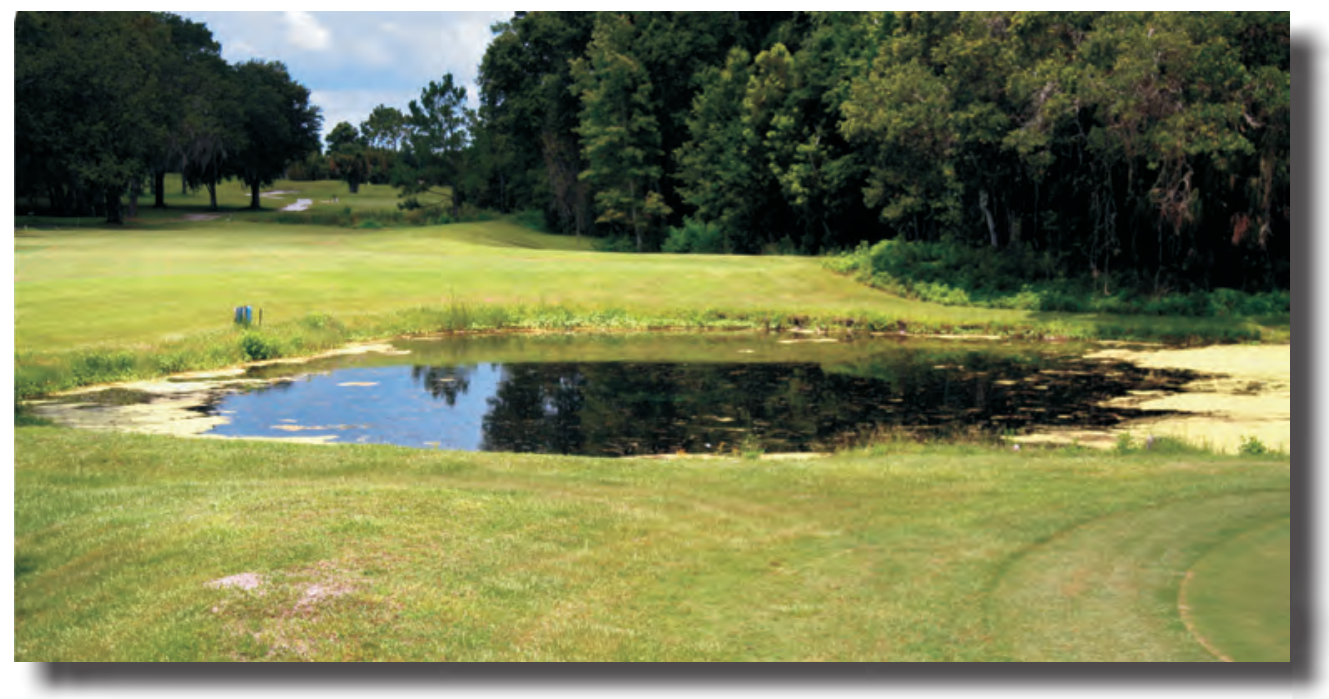

Introduction

Figure 8. Maintenance Spring pool; photo by W. Scott McBride.

Dead Spring (SP9, fig. 5 and table 1), also called Big Hole, is located about $0.1 \mathrm{mi}$ west of $\mathrm{I}-75$ and $0.1 \mathrm{mi}$ south of Shady Brook. No spring flow was detected at Dead Spring during this study, but drought conditions prevailed during the data-collection period and this spring may flow under wetter conditions. Elliot and others (1998) suggest that Dead Spring may be a karst window rather than a spring. A karst window is a subterranean passage exposed at land surface. Karst windows may be wet or dry, but no groundwater discharges from them because the potentiometric surface of the aquifer containing the karst window is below land surface.

Other notable karst features in the Lake Panasoffkee study area include Hogeye Sink, Walled Sink, and Double Sink (fig. 5). Hogeye Sink is located about 1 mi northeast of Fenney Spring (SP18) near the southwest shore of Lake Okahumpka. Hogeye Sink intercepts all or part of the water flowing in Chitty Chatty Creek toward Lake Okahumpka when the potentiometric surface of the Upper Floridan aquifer is below land surface. Hogeye Sink may be a source of water to Lake Okahumpka when the potentiometric surface is above land surface (Simonds and German, 1980). Hogeye Sink is probably hydraulically connected to Fenney Spring (SP18, fig. 5) through subterranean passageways based upon their proximity and the orientation of both features along a northeast/ southwest trending axis. During the study it was observed that after heavy rains, the color of the water emanating from Fenney Spring changes from blue to brown. The blue water is typical of discharge from the Upper Floridan aquifer, whereas the brown tannic-stained water is probably recently recharged surface water. Hogeye Sink and its associated karst features are a probable source of the tannic water, but further study would be needed to confirm this hypothesis.

Walled and Double Sinks, plus at least two other unnamed sinks collectively referred to herein as the Walled Sink Complex, are located near Sumterville about $2.5 \mathrm{mi}$ east-southeast of the intersection of U.S. 301 and S.R. 470 (fig. 5). A 2-mi long unnamed creek flows northward into the sink complex where it recharges directly to the Upper Floridan aquifer. In the late 1960s or early 1970s, a network of canals was dug along the Lake and Sumter County border to drain parts of the Big Prairie watershed (Inwood Consulting Engineers, 2006). Big Prairie Canal flows northwestward out of the Big Prairie watershed and intersects the Walled Sink Complex. Big Prairie Canal probably only flows after excessive rainfall during flooding conditions, because most of the Big Prairie watershed appears to be internally drained. In recent years, mining activities around the Walled Sink Complex have affected the hydrology of the area. Satellite imagery indicates that mining activities have encroached on the sinks and may eventually eliminate them altogether (Southwest Florida Water Management District, 2010). A dry channel crosses under U.S. 301 just south of the intersection with S.R. 470 downstream from the sink complex; it is unclear whether this channel is natural or part of the Big Prairie Canal. In the past, water was likely conveyed along this channel during periods of high water

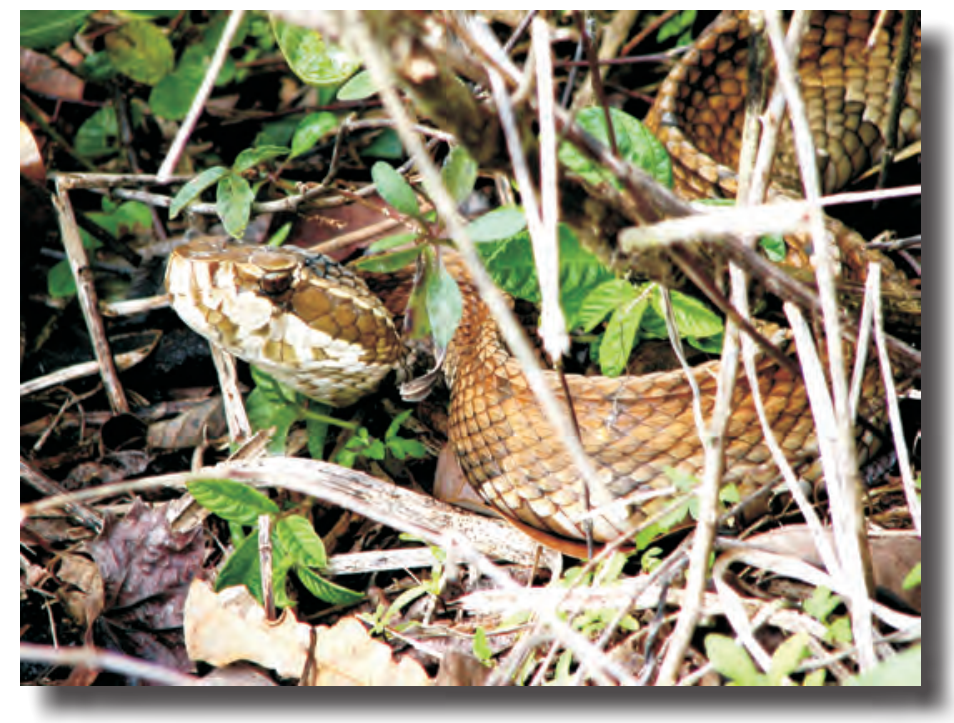

Eastern cottonmouth moccasin; (Agkistrodon piscivorus piscivorus) at Maintenance Spring near Sumterville, Fla.; photo by W. Scott McBride 


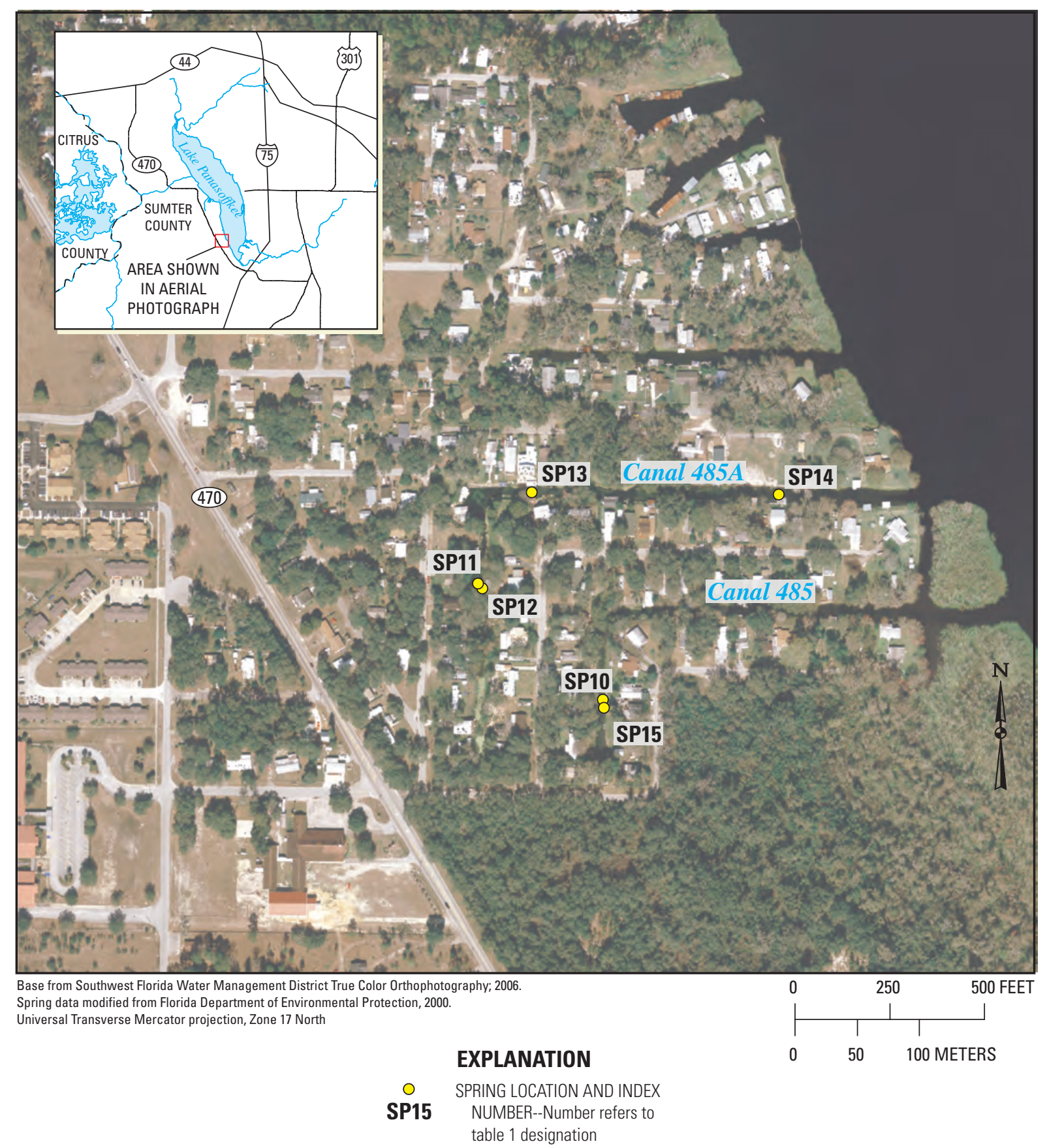

Figure 9. Location of springs in the Canal Springs Complex.

when the sink complex did not have the capacity to accept all of the flow from the Big Prairie watershed. After crossing under U.S. 301, flows would have intersected the Belton's Millpond Spring Complex and Shady Brook before finally emptying into Lake Panasoffkee.

Over the course of this study, no hydrologic data were collected at Hogeye, Walled, or Double Sinks or their related tributaries. None of these sinks appear to contribute flow directly to Lake Panasoffkee or its tributaries under normal hydrologic conditions. Some or all of these features may contribute flows to Lake Panasoffkee during periods of high water, but no connection was observed during the study period.

A series of residential canals and the Outlet River are located on the western shore of Lake Panasoffkee. Canals 485 and 485A (fig. 9), located on the southwestern shore, contain at least six small spring vents, collectively known as Canal Springs Complex, which contribute flow to the 
lake (SP10-SP15, figs. 5 and 9, table 1). Outflow from Lake Panasoffkee is through the Outlet River midway along the western shore of the lake. A rock spillway, with two narrow breaks for the passage of boat traffic, lies across the head of Outlet River. Although the spillway was probably built in the 1880 s as a navigational improvement, the historical record is not clear as to who built the spillway and why (Wharton, 1982). The Outlet River flows west for about $2 \mathrm{mi}$ before emptying into the Withlacoochee River (fig. 2).

Lake Panasoffkee contributes a substantial volume of water to the Withlacoochee River, and this water is especially important during periods of low river flow (Trommer and others, 2009). The Wysong-Coogler Dam (often condensed to "Wysong Dam") is an inflatable bladder dam (fig. 5) located about $2.1 \mathrm{mi}$ downstream from the confluence of the Outlet River and Withlacoochee River near the town of Carlson. This dam helps control stage in the Outlet River and Lake Panasoffkee in addition to the upper part of the Withlacoochee River.

\section{Methods of Investigation}

Multiple approaches were used to quantify the hydrology and surface-water/groundwater interactions in the Lake Panasoffkee watershed. This section describes the techniques and locations used to (1) measure flow, water level, evaporation, and precipitation, and (2) collect and process waterquality and geochemical samples. Geospatial techniques and water-budget methods also are described.

\section{Measurement of Streamflow and Spring Flow}

Surface-water data collection included continuous streamflow and spring stage measurements, and periodic spring flow measurements. Two USGS streamflow gages used in this study were in operation prior to the study period - one since the early 1960s (Outlet River, SW7) and the other since the early 1990s (Shady Brook, SW3) (fig. 10 and table 2). The streamflow gaging network was expanded for this study by adding continuous recorders at Little Jones Creek (SW6), Big Jones Creek (SW5), Warnel Creek (SW1), and an additional gage on Shady Brook (SW2) (fig. 10 and table 2). The second Shady Brook gage was added downstream of the existing station to capture inflow from springs downstream of the original gage. Spring stage monitoring sites were installed at Fenney Spring (SW10), Blue Spring (SW11), Belton's Millpond Spring Complex (SW12), and Maintenance Spring (SW13) (fig. 10 and table 2).

The Canal Springs Complex (fig. 9) was not instrumented because backwater conditions at the springs prevented accurate discharge measurements using acoustic Doppler velocity meters or acoustic Doppler current profilers. Advanced discharge measurement techniques, such as index velocity methods, would need to be applied to accurately measure the flow under these conditions, but application of these advanced techniques was beyond the scope of this study.

Periodic discharge measurements were made at each of the surface-water and spring sites mentioned previously. Rating curves that describe the relation of stage to discharge over the range of observed stages were developed for Little Jones Creek (SW6), Shady Brook (SW2), and Warnel Creek (SW1) (fig. 10 and table 2). Rating curves were necessary at these sites to calculate a water budget for Lake Panasoffkee. Big Jones Creek was not rated because the channel was dry or did not flow during the majority of the study period because of drought conditions. A previously established rating curve for Outlet River (SW7) was used for this study (fig. 10 and table 2).

In addition to the surface-water and spring sites where stage was continuously monitored, periodic discharge measurements were made at one surface-water site and two spring sites. The surface-water site was located on Shady Brook (SW4) and the spring sites were Henry Green Spring (SW8) and Wayne Lee Spring (SW9) (fig. 10 and table 2). Access to these springs was not granted by the private owners, but discharge from the springs was measurable where the spring runs crossed public land. These sites were measured during the four synoptic streamflow runs (seepage runs) conducted during this study.

Seepage runs are used to quantify gains and losses of water under baseflow conditions, which occur during periods of little rainfall when a stream is contained within its banks and stream stage is static. Under these conditions, nearly all of the water entering or leaving a stream is contributed by groundwater, either as spring flow, groundwater inflow, or both. To perform the seepage runs, each stream was divided into reaches and at least one discharge measurement was made within every reach. The length of each reach was primarily

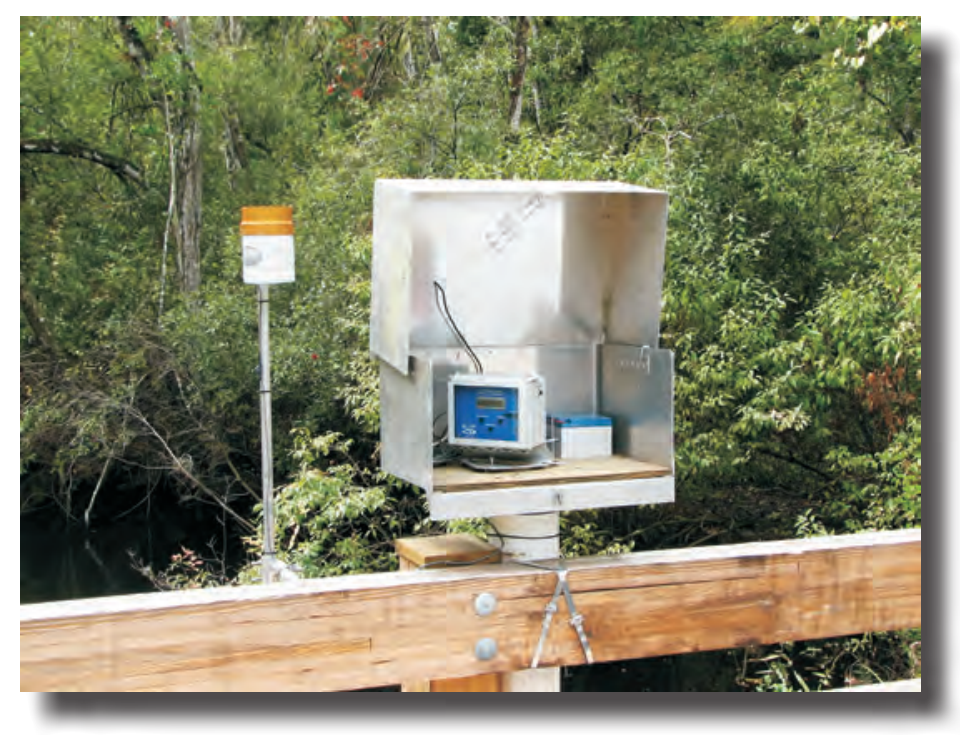

Streamgage showing continuous recorder; photo by W. Scott McBride 


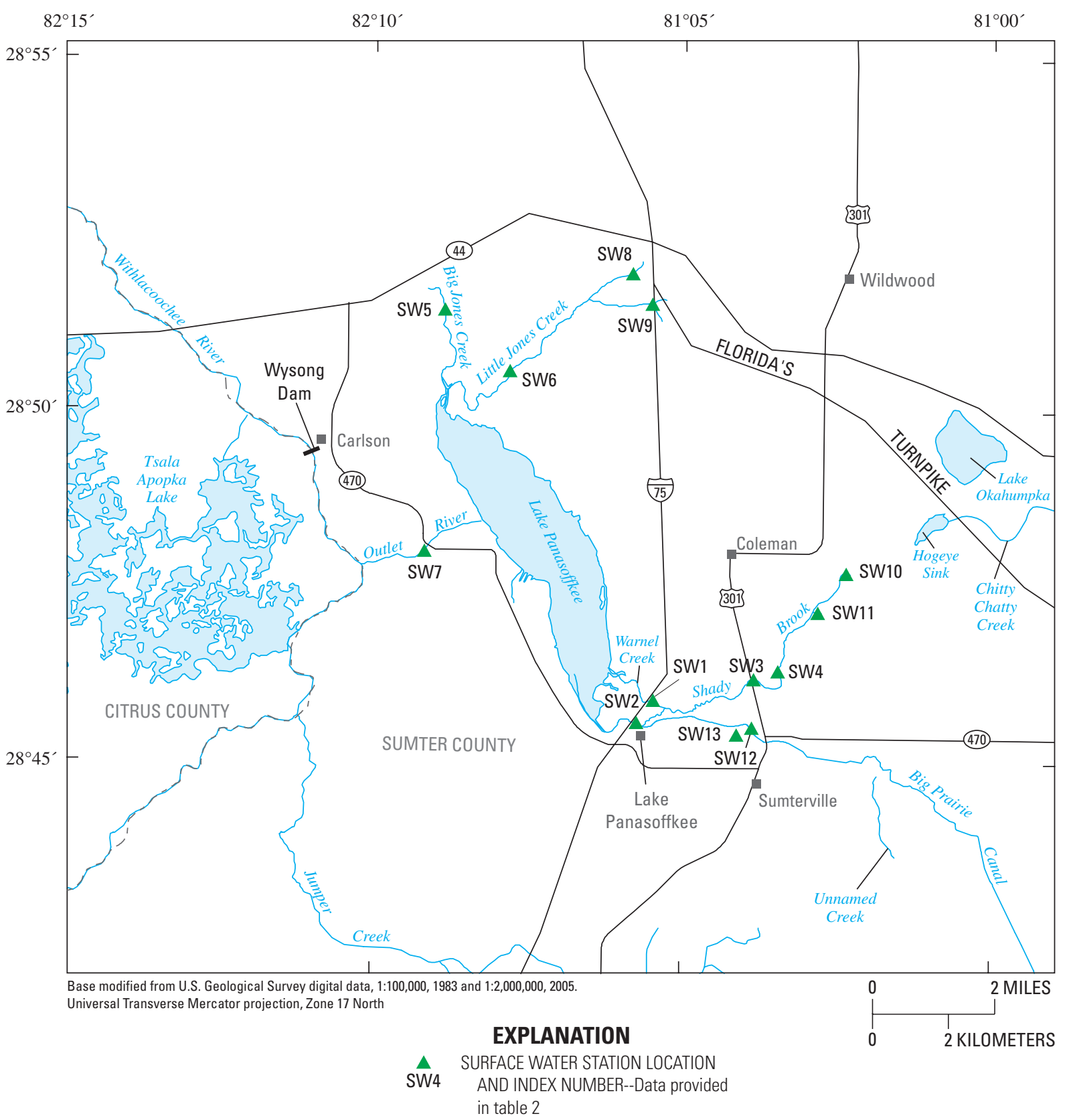

Figure 10. Location of surface-water stations in the Lake Panasoffkee study area. Site identification numbers and names are given in table 2.

determined by the location of stream cross sections suitable for discharge measurements, often at bridge crossings where streamflow is funneled into well-defined channels. Net gains or losses of flow to the main channel from other sources of flow, such as tributaries and springs, also had to be measured. Net gains or losses of flow in excess of the discharge measurement error were attributed to groundwater inflow or outflow from the stream. All of the discharge measurements during a seepage run were performed within as short a time frame as possible, and were typically collected in upstream to downstream order. Seepage runs are usually made only during the dry season, but because of the drought conditions during this study, it also was possible to make them during the summer months, when the conditions are typically wetter and stage is not static.

Sources of discharge data included records of streamflow at USGS gages, acoustic Doppler velocity meter measurements, and acoustic Doppler current profiler measurements. 
Table 2. Location of surface-water stations in the Lake Panasoffkee study area.

[USGS, U.S. Geological Survey]

\begin{tabular}{|c|c|c|c|c|}
\hline $\begin{array}{c}\text { Reference } \\
\text { number } \\
\text { (fig. 10) }\end{array}$ & $\begin{array}{c}\text { USGS site identification } \\
\text { number }\end{array}$ & Station name & Latitude & Longitude \\
\hline SW2 & 284534082054400 & Shady Brook 350 feet above I-75 at Lake Panasoffkee & $28^{\circ} 45^{\prime} 34^{\prime \prime}$ & $82^{\circ} 05^{\prime} 44^{\prime \prime}$ \\
\hline SW3 & 02312667 & Shady Brook near Sumterville & $28^{\circ} 46^{\prime} 12^{\prime \prime}$ & $82^{\circ} 03^{\prime} 50^{\prime \prime}$ \\
\hline SW5 & 285126082085200 & Big Jones Creek 2 miles above Lake Panasoffkee near Carlson & $28^{\circ} 51^{\prime} 26^{\prime \prime}$ & $82^{\circ} 08^{\prime} 52^{\prime \prime}$ \\
\hline SW6 & 02312675 & Little Jones Creek near Rutland & $28^{\circ} 50^{\prime} 33^{\prime \prime}$ & $82^{\circ} 07^{\prime} 49^{\prime \prime}$ \\
\hline SW7 & 02312700 & Outlet River at Panacoochee Retreats & $28^{\circ} 48^{\prime} 00^{\prime \prime}$ & $82^{\circ} 09^{\prime} 11^{\prime \prime}$ \\
\hline SW8 & 285207082054100 & Henry Green Spring Run at Wildwood & $28^{\circ} 52^{\prime} 07^{\prime \prime}$ & $82^{\circ} 05^{\prime} 41^{\prime \prime}$ \\
\hline SW9 & 285133082053100 & Wayne Lee Spring Run at I-75 near Wildwood & $28^{\circ} 51^{\prime} 33^{\prime \prime}$ & $82^{\circ} 05^{\prime} 31^{\prime \prime}$ \\
\hline SW12 & 284530082034800 & Belton's Millpond Complex near Sumterville & $28^{\circ} 45^{\prime} 31^{\prime \prime}$ & $82^{\circ} 03^{\prime} 50^{\prime \prime}$ \\
\hline SW13 & 284525082040600 & Maintenance Spring Run near Sumterville & $28^{\circ} 45^{\prime} 25^{\prime \prime}$ & $82^{\circ} 04^{\prime} 06^{\prime \prime}$ \\
\hline
\end{tabular}

Streamflow at each location was either measured directly or taken from an established rating curve developed for that site. Standard USGS methods, as described in Rantz and others (1982) and Oberg and others (2005), were used to make discharge measurements and compute streamflow. Small differences in streamflow were not always considered significant for calculating seepage gains and losses. When differences in streamflow between stations were greater than 5 percent and the streamflow was greater than $0.5 \mathrm{ft}^{3} / \mathrm{s}$, the gain or loss was considered significant (Hortness and Vidmar, 2005).

\section{Measurement of Groundwater Levels}

Groundwater levels were recorded at six paired monitoring well sites consisting of at least one surficial aquifer monitoring well and one Upper Floridan aquifer monitoring well (fig. 11 and table 3). Temporal patterns of recharge and discharge were evaluated for each site by comparing differences in groundwater levels in each well pair. Two well sites were installed specifically for this study: Big Jones Creek (GW5-GW6) and Little Jones Creek (GW7-GW8) (fig. 11 and table 3). The remaining paired well sites are part of the SWFWMD Regional Observation and Monitoring Well Program (ROMP). These include ROMP wells LP-4 (GW24 and GW26), LP-5 (GW31-GW32), LP-6 (GW37-GW38), and Wysong Dam (GW14-GW15) (fig. 11 and table 3). The "LP" well designation stands for "Lake Panasoffkee," and was assigned to each well by the SWFWMD. At the start of this study, the USGS installed pressure transducers in the wells at Big Jones Creek, Little Jones Creek, LP-4,
LP-5, and Wysong Dam; LP-6 was already instrumented by the SWFWMD. In January 2007, the SWFWMD replaced the USGS instruments with their own at ROMP sites LP-4 (GW24 and GW26) and LP-5 (GW31-GW32) as part of a long-term groundwater-level monitoring project.

Three drivepoint piezometers (temporary, small diameter wells used to determine the elevation of the water table) were installed along the shore of Lake Panasoffkee (GW18, GW22, and GW39) to study the relation between the lake elevation and the water table in the shallow surficial aquifer beneath the lake (fig. 11 and table 3). A fourth piezometer was installed on the bank of Shady Brook about 0.5 mi upstream of Lake Panasoffkee (GW30). One piezometer (GW39) was destroyed shortly after installation by lake restoration activities and was never replaced because of continued restoration activity in the area. The drivepoint piezometers consisted of 0.75 -in. diameter stainless-steel drivepoints about 9 in. long that were perforated with holes backed with a fine stainless-steel screen. The drivepoints were screwed onto a 0.75 -in. diameter steel pipe and manually driven to depth, typically between 3 and $10 \mathrm{ft}$ below land surface. Water levels in some of the first piezometers installed were slow to equilibrate to surrounding surficial aquifer water levels after installation, sometimes requiring 1 full day to equilibrate. Upon removal, one of the first piezometers installed was inspected and found to have the drivepoint openings sealed over with clayey sand. After this discovery, all of the piezometers were flushed with water using a 0.375 -in. diameter threaded steel rod as a surging tool. Three rubber washers were sandwiched between steel nuts at one end of the rod. The rubber washers created a tight seal inside the piezometer bore, and when the steel rod was lowered to the bottom of the piezometer and plunged up and 


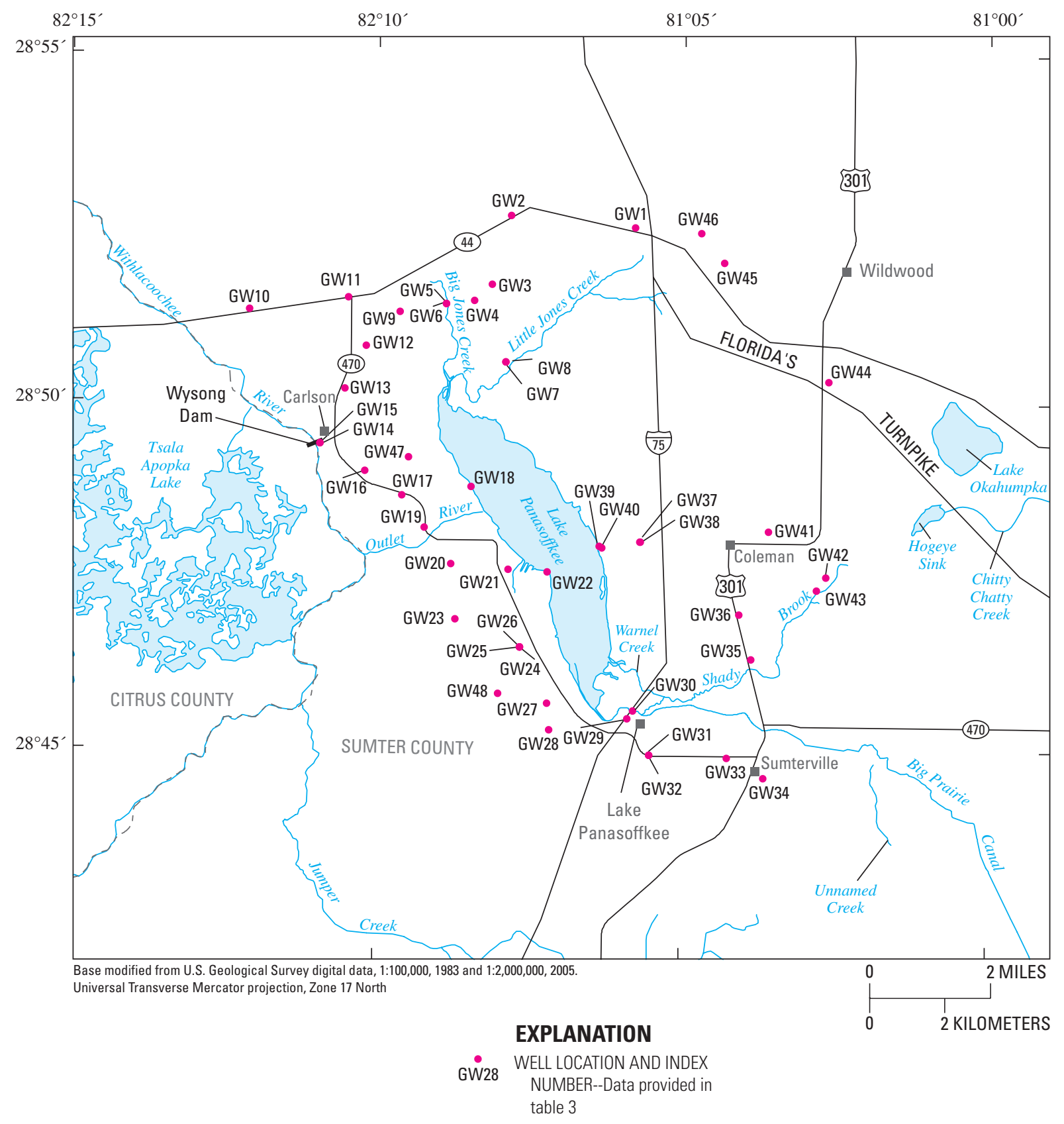

Figure 11. Location of wells in the Lake Panasoffkee study area. Site identification numbers and names are shown in table 3.

down, the resulting change in pressure forced water in and out of the drivepoint openings. The flushing water cleared the drivepoint perforations of debris encountered during the installation process. Afterwards, water levels in the piezometers equilibrated within a few hours instead of days.

Surficial aquifer water levels were measured in these piezometers using a graduated steel tape to measure the distance from a permanently inscribed measuring point at the top of the steel casing down to the equilibrated groundwater level inside the casing. If the piezometers were standing in lake water at the time of the measurement, the lake level was recorded by measuring the distance from the measuring point on the piezometer down to the lake water surface. If lake levels were low and the piezometers were on dry ground, the lake levels were measured using a nearby independent reference point permanently mounted over the lake water surface. 
Table 3. Additional wells in the Lake Panasoffkee study area used to augment regional potentiometric-surface and water-table maps.

[USGS, U.S. Geological Survey; WMA, wildlife management area; UFA, Upper Floridan aquifer; SA, surficial aquifer; ft, feet]

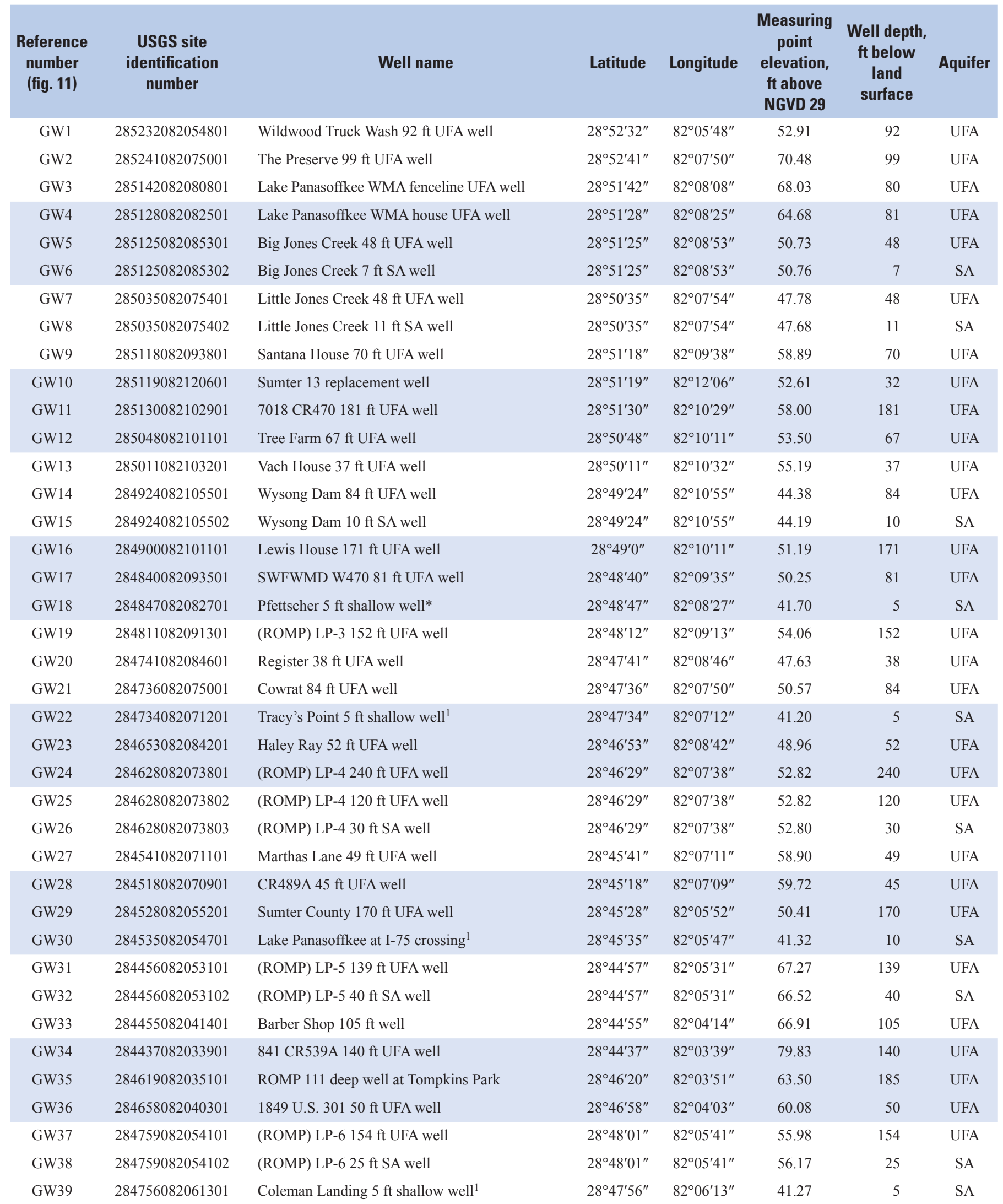


Table 3. Additional wells in the Lake Panasoffkee study area used to augment regional potentiometric-surface and water-table maps. Continued

[USGS, U.S. Geological Survey; WMA, wildlife management area; UFA, Upper Floridan aquifer; SA, surficial aquifer; ft, feet]

\begin{tabular}{|c|c|c|c|c|c|c|c|}
\hline $\begin{array}{c}\text { Reference } \\
\text { number } \\
\text { (fig. 11) }\end{array}$ & $\begin{array}{c}\text { USGS site } \\
\text { identification } \\
\text { number }\end{array}$ & Well name & Latitude & Longitude & $\begin{array}{c}\text { Measuring } \\
\text { point } \\
\text { elevation, } \\
\text { ft above } \\
\text { NGVD } 29\end{array}$ & $\begin{array}{l}\text { Well depth, } \\
\text { ft below } \\
\text { land } \\
\text { surface }\end{array}$ & Aquifer \\
\hline GW40 & 284755082061101 & Coleman Landing SA monitor well & $28^{\circ} 47^{\prime} 55^{\prime \prime}$ & $82^{\circ} 06^{\prime} 11^{\prime \prime}$ & 41.78 & 13 & SA \\
\hline GW41 & 284810082033501 & Spurling Dr 84 ft UFA well & $28^{\circ} 48^{\prime} 10^{\prime \prime}$ & $82^{\circ} 03^{\prime} 35^{\prime \prime}$ & 64.79 & 84 & UFA \\
\hline GW43 & 284720082024801 & Fenney Spring $18 \mathrm{ft}$ SA well & $28^{\circ} 47^{\prime} 20^{\prime \prime}$ & $82^{\circ} 02^{\prime} 48^{\prime \prime}$ & 54.97 & 18 & SA \\
\hline GW44 & 285020082023701 & Sleep Inn $85 \mathrm{ft}$ UFA well & $28^{\circ} 50^{\prime} 20^{\prime \prime}$ & $82^{\circ} 02^{\prime} 37^{\prime \prime}$ & 61.77 & 85 & UFA \\
\hline GW45 & 285202082042001 & Caruthers $130 \mathrm{ft}$ UFA well & $28^{\circ} 52^{\prime} 02^{\prime \prime}$ & $82^{\circ} 04^{\prime} 20^{\prime \prime}$ & 70.05 & 130 & UFA \\
\hline GW46 & 285227082044301 & Caruthers Windmill $132 \mathrm{ft}$ UFA well & $28^{\circ} 52^{\prime} 27^{\prime \prime}$ & $82^{\circ} 04^{\prime} 43^{\prime \prime}$ & 112.24 & 132 & UFA \\
\hline GW47 & 284912082092901 & 3847 CR470 39 ft UFA well & $28^{\circ} 49^{\prime} 12^{\prime \prime}$ & $82^{\circ} 09^{\prime} 29^{\prime \prime}$ & 53.16 & 39 & UFA \\
\hline
\end{tabular}

${ }^{1}$ Temporary piezometer.

Water-level measurements at 31 Upper Floridan aquifer wells around Lake Panasoffkee were coordinated to coincide with the measurement of the more than 1,100 wells used to create the May (dry season) and September (wet season) regional potentiometric-surface maps of the Upper Floridan aquifer throughout central Florida (Kinnaman and Dixon, 2008; Ortiz, 2008a, b, c, and 2009). The additional 31 wells in the vicinity of Lake Panasoffkee were combined with about 340 of the regional wells (app. 1) to create more detailed potentiometric-surface maps within the study area. The number of wells measured during each synoptic water-level survey varied slightly because of difficulties in measuring water levels in certain wells, and because new wells were sometimes added to the surveys when gaps in data coverage were identified. In addition to the monitoring wells, domestic (household) wells were frequently used to help define the Upper Floridan aquifer potentiometric surface within the study area because many of these wells were available in suitable condition for use. Surficial aquifer water levels were also measured during the synoptic surveys at the three piezometer and six paired well sites described above.

\section{Geospatial Techniques}

Each of the Upper Floridan potentiometric-surface and surficial aquifer water-table maps was created in a geographic information system (GIS) environment using the tension-splines interpolation method (Buto and Jorgensen, 2007; Environmental Systems Research Institute, Inc., 2009). This is an exact interpolator technique that allows the resulting raster surfaces to match the values of the input datapoints used to create the surface. The resulting Upper Floridan aquifer potentiometric-surface raster grid was then subtracted from the surficial aquifer water-table raster grid to estimate the difference in water level between the two aquifers. Positive water-level differences resulted in areas where Upper Floridan aquifer water levels exceeded the surficial aquifer water levels, indicating potential for upward groundwater discharge. Negative water-level differences indicated areas of groundwater recharge potential from the surficial aquifer to the Upper Floridan aquifer. The raster grids also were used to draw water-level contour lines, which were then modified in GIS to remove artifacts of the interpolation process.

A geostatistical cross validation was then run on the input datasets used to create the raster grids in which each water-level datapoint was removed iteratively and the raster was interpolated using the remaining datapoints. The resulting difference between each removed point and the interpolated value at that location is the error. These methods are set forth in the National Standard for Spatial Data Accuracy (Federal Geographic Data Committee, 1998).

The surface-water drainage basin was delineated using the best available data from the National Elevation Dataset (Gesch and others, 2002; Gesch, 2007). The digital elevation model was derived from cartographic contours and mapped hydrography, and was resampled to a horizontal resolution of $10 \mathrm{~m}$ (32.8 ft). The data were downloaded from the USGS National Map Seamless Server and processed using ArcHydro (Maidment, 2002) within the ArcGIS (Environmental Systems Research Institute, 2006) working environment. 


\section{Calculation of Evaporation and Groundwater Inflow}

Previous water-budget studies of Lake Panasoffkee used estimates of evaporation and diffuse groundwater inflow in their calculations (CH2M Hill, 1995). In this study, lake evaporation was measured by installing a floating data-collection raft over the deepest section of the lake. The suite of instrumentation on the raft collected the data necessary for calculating the lake evaporation rate using an energy-budget method. The raft included sensors for measuring air temperature, water temperature at $1-\mathrm{ft}$ intervals, relative humidity, windspeed, and net radiation. Thermal surveys were performed every other week at nine stations on Lake Panasoffkee to determine if the lake water temperature was well mixed vertically, and to ensure that water-temperature data collected at the raft were representative of the entire lake system. At each of the nine thermal stations, a weighted thermistor was lowered to the lake bottom and then raised 3 to 6 in. above the sediment. Temperature readings were recorded at $1-\mathrm{ft}$ intervals from the lake bottom to the water surface. The instrumentation was serviced on the same days the thermal surveys were performed. The SWFWMD has previously performed bathymetric surveys that were used to calculate the lake volume. More detailed descriptions of equipment and energy-budget equations are presented in Swancar and others (2000) and Allander and others (2009).

Evaporation from the lake surface was calculated using the energy-budget equation, originally described by Anderson (1954) and applied more recently in Florida by Swancar and others (2000). Evaporation is calculated as the residual term of a lake-energy budget for which all other terms are either measured or estimated, using the equation:

$$
E_{E B}=Q_{n}+Q_{v}-Q_{x} /\left[c\left(T_{O}-T_{b}\right)+\rho\left(L^{*}(1+B R)\right)\right]
$$

where

$E_{E B}$ is energy-budget evaporation rate, in centimeters per day;

$Q_{n}$ is net radiation, in calories per square centimeter per day;

$Q_{v}$ is advected energy from all inflows and outflows, in calories per square centimeter per day;

$Q_{x}$ is change in stored energy, in calories per square centimeter per day;

$c$ is the specific heat of water, $1 \mathrm{cal} / \mathrm{cm}^{3}$;

$T_{O}$ is water-surface temperature, in degrees Celsius;

$T_{b}$ is the base temperature, in degrees Celsius;

$\rho$ is the density of water, $1 \mathrm{~g} / \mathrm{cm}^{3}$;

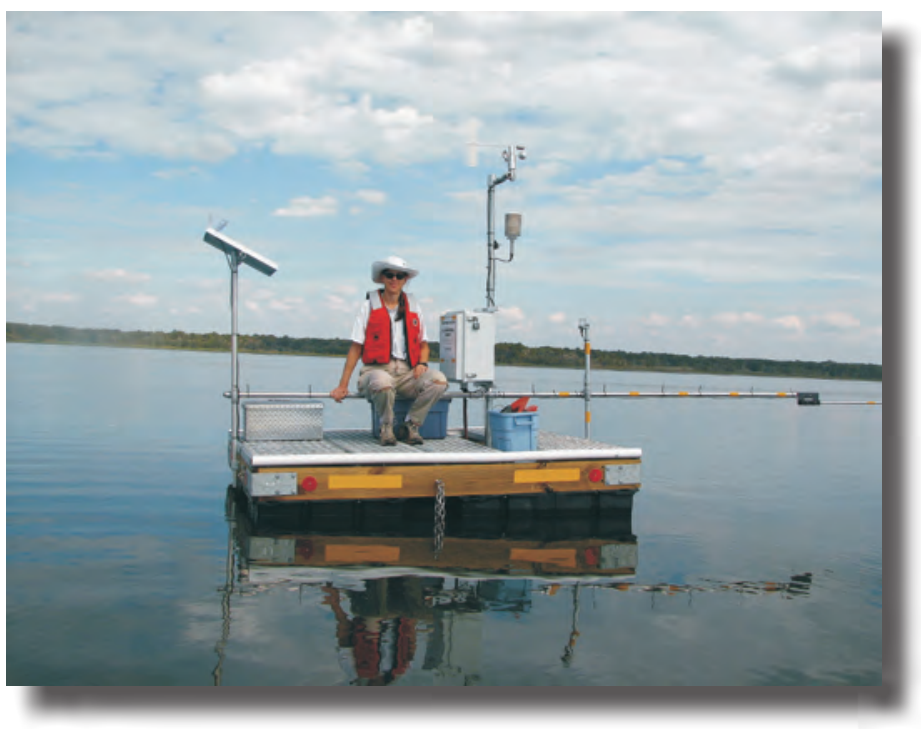

Floating data-collection raft on Lake Panasoffkee, carrying a suite of instrumentation to measure air and water temperature, relative humidity, windspeed, and net radiation; photo by W. Scott McBride

$L$ is latent heat of vaporization, a function of air temperature, in calories per gram; and

$B R$ is the Bowen ratio (the ratio of sensible to latent heat) calculated from:

$$
\gamma P\left(T_{O}-T_{a}\right) /\left(e_{O}-e_{a}\right)
$$

where

$\gamma$ is the psychrometric constant, which varies from 0.66 to 0.67 depending on atmospheric pressure and temperature, in millibars per degree Celsius;

$P$ is atmospheric pressure, set to 1,013 millibars;

$T_{a}$ is air temperature, in degrees Celsius;

$e_{O}$ is saturation vapor pressure at water-surface temperature, in millibars; and

$e_{a}$ is vapor pressure at air temperature, in millibars.

When considering the energy content of a water body of varying mass, a base temperature, $T_{b}$, must be selected to calculate the advected energy term, $Q_{v}$ (Anderson, 1954; Saur and Anderson, 1956). For this application, the average temperature of the largest unknown flux, groundwater inflow, was used as the base temperature to reduce the effect of errors in quantifying this term on the calculated evaporation.

Groundwater inflow, $Q^{G W_{i n}}$, is the diffuse flow (or discharge) of groundwater to Lake Panasoffkee through the porous lakebed. Groundwater inflow also occurs through the streambeds of the tributaries that feed Lake Panasoffkee, 
but this inflow is accounted within the lake water budget as discharge measured at stream gages located near the mouth of each tributary. Groundwater fluxes are dependent on the relations among the lake water level, surficial aquifer water level, and the Upper Floridan aquifer water level (Schiffer, 1998). If the elevation of the potentiometric surface of the Upper Floridan aquifer is greater than the lake water level, there is potential for groundwater inflow into the lake. Groundwater inflow occurs within the surficial aquifer, if present, or directly from the Upper Floridan aquifer where the lake is in direct contact with the aquifer (Schiffer, 1998). Seepage losses from Lake Panasoffkee to the underlying aquifer are assumed to be negligible because of the upward difference. This is atypical of most Florida lakes, which have both groundwater inflow and outflow (Sacks and others, 1998; Schiffer, 1998).

Groundwater inflow to the lake was calculated as the residual term of the lake water-budget equation:

$$
Q^{G W}{ }_{i n}=\Delta S-P r+E_{E B}-Q^{S W}{ }_{i n}+Q^{S W}{ }_{\text {out }}-Q^{O W T S_{i n}}
$$

where

$$
\begin{array}{r}
Q^{G W} \text { in } \text { is monthly groundwater inflow, in cubic feet; } \\
\Delta S \text { is monthly change in lake storage, in cubic feet; } \\
P r \text { is monthly rainfall on the lake, in cubic feet; } \\
E_{E B} \text { is monthly energy-budget evaporation, in } \\
\text { cubic feet; } \\
Q^{S W} \text { in } \text { is monthly surface-water inflow, in cubic feet; } \\
Q^{S W} \text { out is monthly surface-water outflow (including } \\
\text { dredging outflow), in cubic feet; and } \\
Q^{\text {OWTS }} \text { in monthly groundwater inflow from onsite } \\
\text { wastewater-treatment systems, in cubic feet. }
\end{array}
$$

All water-budget terms are expressed in both cubic feet and as inches of water over the average lake surface area for each month. Errors in each term were based on a previous study conducted in central Florida (Swancar and others, 2000) and were combined to estimate the error in groundwater inflow using the following equation (Sacks and others, 1998):

$$
\begin{aligned}
& \operatorname{Err}^{G W_{i n}}=\left[[(0.05(\Delta S))]^{2}\right. \\
& +(0.05(P r))^{2}+\left(0.15\left(E_{E B}\right)\right)^{2} \\
& +\left(0.10\left(Q^{\left.S W_{\text {in }}\right)}\right)^{2}+\left(0.05\left(Q^{S W_{\text {out }}}\right)\right)^{2}\right. \\
& \left.\left.+\left(1.00\left(Q^{\text {OWTS }}{ }_{i n}\right)\right)^{2}\right]\right]^{0.5}
\end{aligned}
$$

Errors in monthly water-budget terms were assumed to be 5 percent for change in stage/volume, monthly rainfall, and surface-water outflows; 10 percent for surface-water inflows; 15 percent for evaporation; and 100 percent for onsite septic wastewater-treatment system (OWTS).

\section{Collection of Precipitation Data}

The average monthly rainfall for the Lake Panasoffkee region was calculated using rainfall data compiled by the National Climatic Data Center (NCDC) from the Inverness 3E weather station (084289) at Inverness, Florida, from 1930 to 2008 (fig. 12). Nine missing data records in the Inverness location were filled by using data from other nearby NCDC weather station sites (Ocala 2NE station (086419) near Ocala, Florida, or the Bushnell 1E station (081163) near Bushnell, Florida) (fig. 12). The average 78-year monthly rainfall for the region was computed to assess the variability in wet or dry season rainfall during the study period compared to long-term average rainfall.

During water years 2007 and 2008, the USGS collected rainfall data at three stations within the Lake Panasoffkee watershed using electronic tipping-bucket sensors. These sensors were located at Little Jones Creek (station 02312675), Outlet River (station 02312700), and Withlacoochee River at Wysong Dam (station 02312720) (fig. 12). The sensors were calibrated annually in the laboratory both before and after deployment to track data quality; no corrections to the data were needed. While deployed in the field, the sensors were regularly checked for debris and obstructions and tested for operability. Once the rainfall data were collected, daily rainfall totals were summed to determine the monthly rainfall for each station. The average of the three monthly rainfall totals was used as the total monthly rainfall for the entire Lake Panasoffkee watershed. The same procedure was used to determine the total rainfall in the Lake Panasoffkee watershed for water year 2006, using rainfall data collected at two SWFWMD stations, LP-6 (2760) and Lake Panasoffkee (6087), because the USGS rain sensors were not yet installed (fig. 12).

\section{Determination of Lake Volume and Change in Storage}

To calculate lake volume and the change in storage as lake levels fluctuated, it was necessary to know the shape and depth of the lake. A triangulated irregular network (TIN) model of the bottom of Lake Panasoffkee was developed by the SWFWMD in 2005 using point-depth measurements along $1,000-\mathrm{ft}$ transects across the lake. The TIN model incorporates areas susceptible to inundation around the lake, with elevations up to $44 \mathrm{ft}$ above NGVD 29 (fig. 13). This model was obtained by the USGS and used to interpolate volumes and surface areas at $0.01-\mathrm{ft}$ intervals of lake stage. These calculations were then used in the water- and energy-budget equations as required.

Water and sediment were removed from the lake throughout much of this study by a dredge that operated on an intermittent schedule, up to 24 hours a day, as part of the Lake Panasoffkee restoration effort. Full scale restoration efforts began in December 2003 and were completed in October 2008 


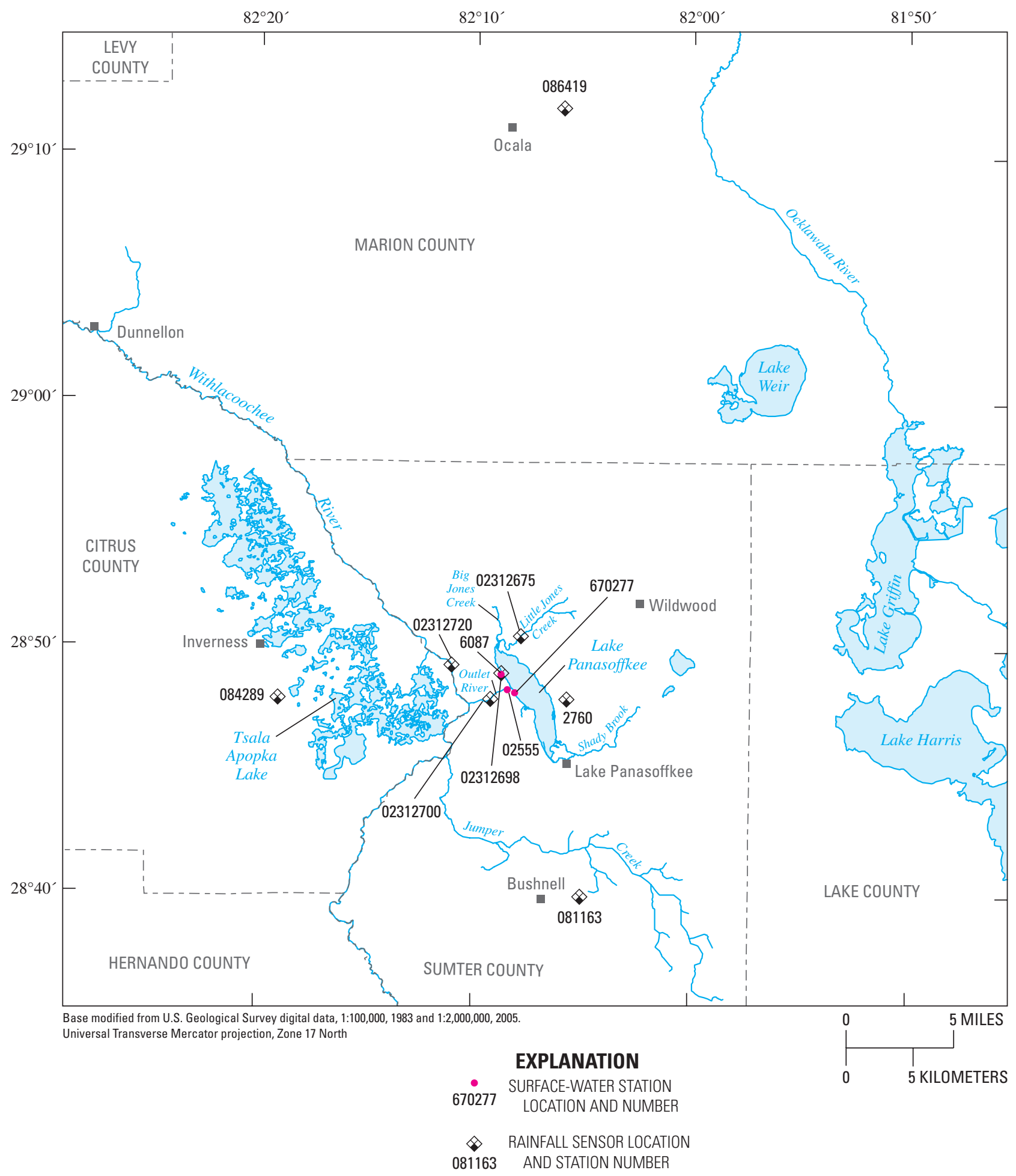

Figure 12. Location of rain gages and current and historic lake-stage gages in the Lake Panasoffkee study area. 


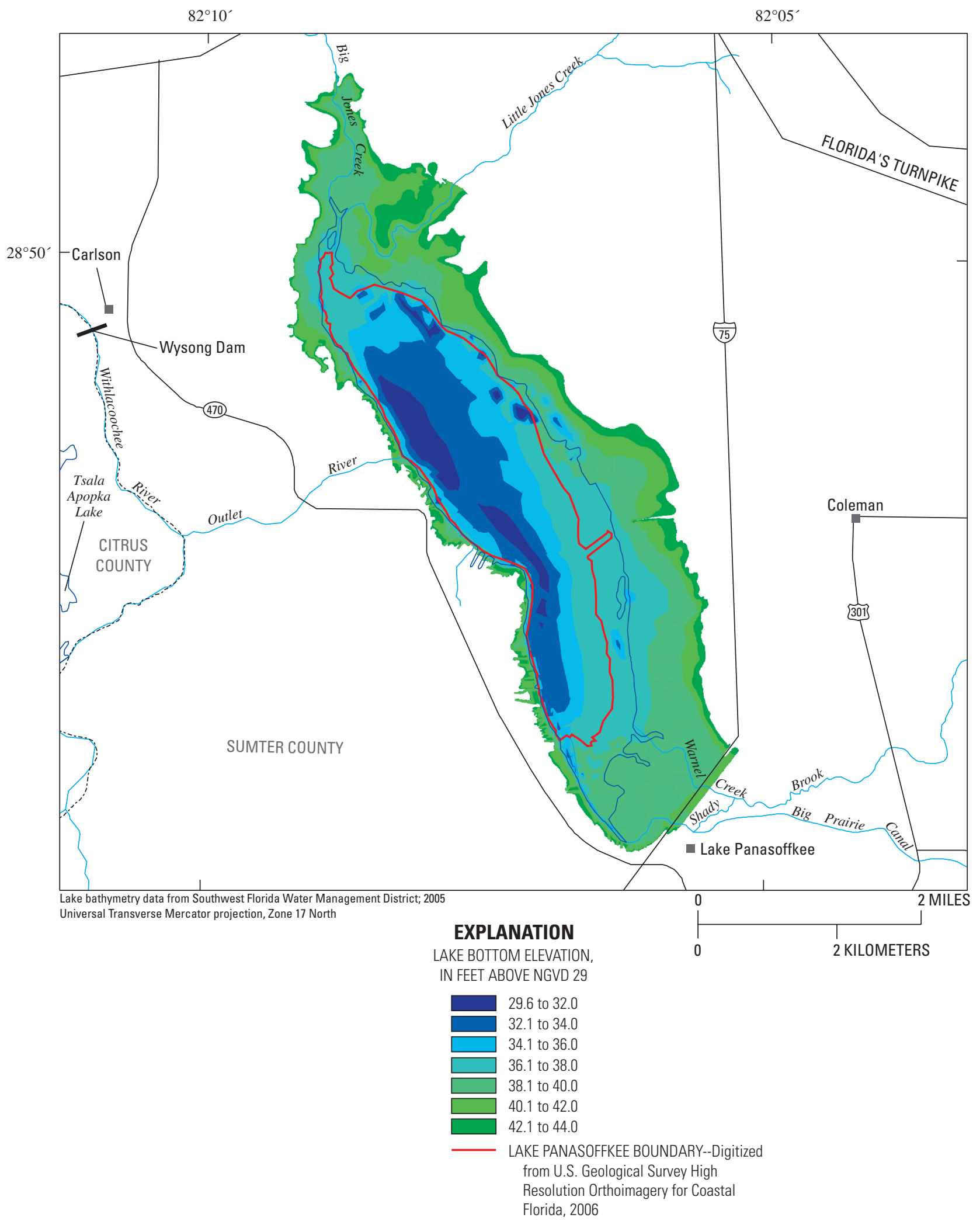

Figure 13. Lake Panasoffkee bathymetric model. 
(Lake Panasoffkee Restoration Council, 2008). A detailed daily log of the number of hours of pumping was kept by the dredge operator. The number of hours of daily pump operation was multiplied by the nominal pumping rate to estimate the volume of water and sediment removed from the lake each day. The average solids content of the pumpage was estimated by the SWFWMD to be 10-13 percent by weight. Using a rough estimate of $2.66 \mathrm{~g} / \mathrm{cm}^{3}$ for the density of silt particles, the average solids content of the pumpage was calculated to be about 5 percent by volume. This factor was applied to the total daily pumpage to estimate the volume of water and sediment removed from the lake. Daily water and sediment calculations were then summed by month, and estimates of water removed were incorporated into the water-budget calculations.

Three stations with continuous water-level recorders have been used to measure stage at Lake Panasoffkee (fig. 12). One station was operated by the USGS (02312698 - Lake Panasoffkee near Lake Panasoffkee, Florida) from 1955 through 2006. In February 2007, after the USGS station was discontinued, the SWFWMD installed a station with a water-level recorder on Lake Panasoffkee (670277 - Lake Panasoffkee-Jeffcoat). A third station, also operated by the SWFWMD, is located on the Outlet River about $800 \mathrm{ft}$ downstream of Lake Panasoffkee (02555 - Pana Vista Outlet River). This station was in operation throughout the entire study period. Although this station is located on the Outlet River, the data collected differed minimally from data collected at the Jeffcoat gage. The average difference between the water-level data at Pana Vista Outlet River and Lake Panasoffkee-Jeffcoat was $0.03 \mathrm{ft}$. Because it was equally representative of lake stage and covered the entire study period, the water-level data from the Pana Vista Outlet River station were used to represent lake stage for this analysis.

\section{Geophysical Measurements}

The shallow hydrogeologic framework underlying Lake Panasoffkee was investigated using high-resolution seismic sub-bottom profiling equipment. The survey was conducted using a C-Products low-voltage seismic-reflection boomer with Teledyne Instruments SDS-55 10-receiver hydrophones. An EdgeTech 3200-XS sub-bottom profiler with SB 424 compressed high intensity radar pulse (CHIRP) towfish also was used. Both units are towed behind a motor boat and collect continuous data.

Two electromagnetic seepage meters were installed in Lake Panasoffkee to directly quantify groundwater inflow into the lake. The seepage meters consisted of aluminum domes of known volume that were driven into the lake bottom with as little disturbance to the underlying sediments as possible. All trapped air was released from inside the domes by way of a valve. The domes are essentially upside-down funnels that concentrate the bidirectional exchange of groundwater and surface water through a narrow neck fitted with an electromagnetic flow meter capable of detecting seepage velocities as low as 4 in/d (Swarzenski, 2004).

\section{Water Chemistry Sampling Methods and Analysis}

Water-chemistry data are helpful in evaluating the sources of water and groundwater flow paths within the watershed, and for assessing the processes controlling the surface-water and groundwater quality. In particular, isotopic and age dating parameters can be useful for determining the transport mechanisms of flow through a hydrologic system. Sources of water to Lake Panasoffkee include rainfall, springs, tributaries, and the surficial aquifer and Floridan aquifer system. All of these sources affect the chemistry of the lake water and provide information about the water's origin.

Samples were collected in July 2007, and in December 2008 through January 2009 to characterize the water quality in the Lake Panasoffkee watershed. Samples were collected from Lake Panasoffkee, tributaries, springs, and groundwater. Groundwater samples were collected from wells installed in the surficial aquifer and Upper Floridan aquifer, and a single sample was collected from the Lower Floridan aquifer below middle confining unit I.

The first round of samples was collected in July 2007 at 12 groundwater sites, 5 spring sites, and 7 surface-water sites (fig. 14 and table 4). Samples were analyzed for dissolved major ions and some trace metals, dissolved organic carbon, nutrients, and the isotopic ratios of strontium $\left({ }^{87} \mathrm{Sr} /{ }^{86} \mathrm{Sr}\right)$, oxygen $\left({ }^{18} \mathrm{O} /{ }^{16} \mathrm{O}\right)$, and hydrogen $\left({ }^{2} \mathrm{H} / \mathrm{H}\right)$. Dissolved major ions and trace metals, dissolved organic carbon, and nutrient samples were analyzed by the USGS National Water-Quality Laboratory in Denver, Colorado. The ${ }^{87} \mathrm{Sr} /{ }^{86} \mathrm{Sr}$ ratios were determined by the USGS Water Resources Radiogenic Isotope Laboratory in Menlo Park, California. The USGS Stable Isotope Laboratory in Reston, Virginia, analyzed samples for ${ }^{18} \mathrm{O} /{ }^{16} \mathrm{O}$ and ${ }^{2} \mathrm{H} / \mathrm{H}$.

The second round of water-quality samples was collected from December 2008 through January 2009. Samples were collected at 17 groundwater sites, 4 spring sites, and 5 surfacewater sites (fig. 14 and table 4). Compared to July 2007, five additional groundwater sites were sampled and one spring and two surface-water sites were dropped. The samples were collected using the same USGS protocols described earlier and samples were analyzed for the same properties, but additional age dating and isotope samples were collected at select sites. Chlorofluorocarbons (CFCs) and sulfur hexafluoride $\left(\mathrm{SF}_{6}\right)$ age dating samples were collected at 11 groundwater sites and were analyzed at the USGS Chlorofluorocarbon Laboratory in Reston, Virginia. Samples from the three deepest monitoring wells were analyzed for the radioactive isotopes of carbon $\left({ }^{14} \mathrm{C}\right)$ and hydrogen $\left({ }^{3} \mathrm{H}\right.$, tritium). Analysis of the ${ }^{14} \mathrm{C}$ samples was done at the National Ocean Sciences Accelerator Mass Spectrometry Facility in Woods Hole, Massachusetts, whereas the ${ }^{3} \mathrm{H}$ samples were analyzed at the University of Miami Tritium Laboratory in Miami, Florida. Water-quality samples were collected following methods described in the USGS National Field Manual for the Collection of Water-Quality Data (U.S. Geological Survey, variously dated). 


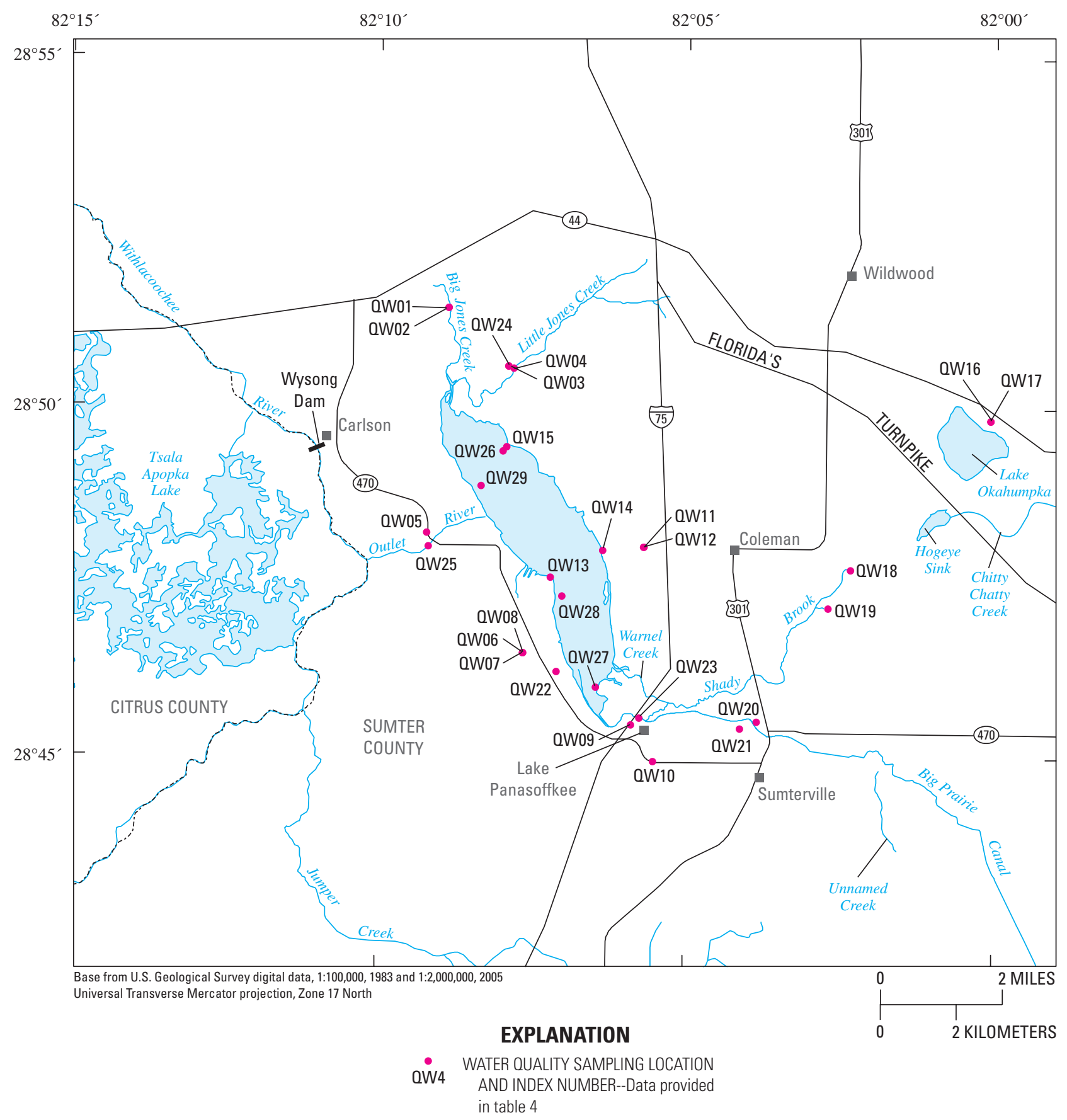

Figure 14. Location of water-quality sampling stations in the Lake Panasoffkee study area. Site identification numbers and names are given in table 4.

Groundwater and spring-water samples were collected using a submersible pump with polytetrafluoroethylene (Teflon ${ }^{\circledR}$ ) tubing to minimize cross contamination between sampling sites. Wells were purged a minimum of three casing volumes before samples were collected. Specific conductance, water temperature, dissolved oxygen, $\mathrm{pH}$, and turbidity were monitored during the removal of the third well-casing volume to determine if the water chemistry was stable before water samples were collected. Springs were sampled by lowering a submersible pump head into the spring vent to ensure that the spring water did not mix with surface water before the sample was collected. The same field properties as groundwater samples, minus turbidity, were monitored for stability before spring-water samples were collected.

Surface-water samples were collected using a stainless-steel weighted bottle sampler with a 1-liter Teflon ${ }^{\circledR}$ collection bottle and nozzle. The stainless-steel sampler was slowly lowered through the water column while the sampler was 
Table 4. Location of water-quality sampling stations in the Lake Panasoffkee study area.

[GW, groundwater; SW, surface water, UFA, Upper Floridan aquifer; SA, surficial aquifer; LFA, Lower Floridan aquifer; —, not available; ft, feet; n/a, not applicable]

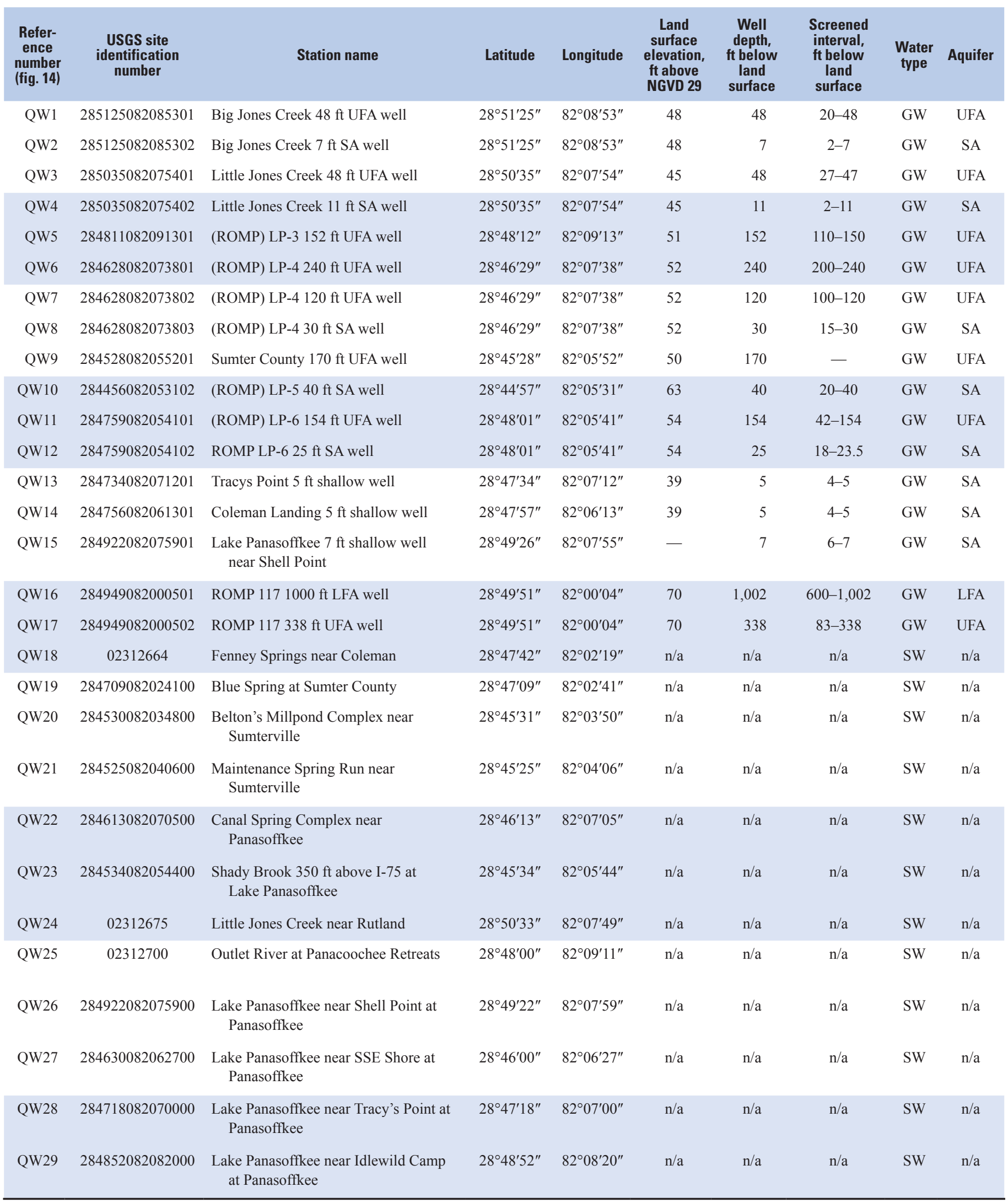


filling in order to collect a depth-integrated sample. At stream sites, water samples were collected with respect to both water depth and at multiple points across the stream channel to ensure that samples were representative of the entire stream cross section. At surface-water sites, specific conductance, $\mathrm{pH}$, temperature, and dissolved oxygen were measured at middepth at each sampling point.

Alkalinity (as calcium carbonate) was measured in the field for all samples using fixed end-point titration methods. Sampling equipment was cleaned onsite after the collection of each sample using dilute phosphate-free detergent, followed by three rinses with deionized water.

High-precision measurements of the ratio of ${ }^{87} \mathrm{Sr} /{ }^{86} \mathrm{Sr}$ in carbonate sedimentary rock can be correlated to specific units within an aquifer (DePaolo and Ingram, 1985). The ${ }^{87} \mathrm{Sr} /{ }^{86} \mathrm{Sr}$ ratio of a water sample can be used to determine the hydrogeologic units the water sample has been in contact with. Samples with the lowest strontium isotope ratios typically have been in contact with the oldest aquifer materials. This result is possible because many marine organisms build their shells from carbonate minerals precipitated from seawater that record the ratio of ${ }^{87} \mathrm{Sr} /{ }^{86} \mathrm{Sr}$ in seawater at the time of shell formation. The isotopic ratio of ${ }^{87} \mathrm{Sr} /{ }^{86} \mathrm{Sr}$ does not vary spatially in modern seawater, but it has slowly changed over millions of years. It is possible to determine the source of a groundwater sample by comparing the ${ }^{87} \mathrm{Sr} /{ }^{86} \mathrm{Sr}$ ratio of a water sample with that of the individual lithologic units of the Floridan aquifer system.

The stable isotopes of oxygen and hydrogen, ${ }^{18} \mathrm{O}$ and ${ }^{2} \mathrm{H}$, are useful in determining sources of water, flow patterns, and mixing of waters. Their stability and incorporation into water molecules make these isotopes excellent tracers of water origin and movement. Other common tracers, such as dissolved constituents, may undergo chemical reactions or move through a flow system at a different rate than the water itself. Deuterium $\left({ }^{2} \mathrm{H}\right)$ is a heavy isotope of hydrogen that accounts for about 0.015 percent of the hydrogen on Earth, whereas oxygen-18 $\left({ }^{18} \mathrm{O}\right)$, the heavy form of oxygen, accounts for about 0.204 percent of the oxygen on Earth (Clark and Fritz, 1997). Because of their low concentrations on Earth, these isotopes are not measured directly. Instead, the ratio of the heavy to light form of the isotope is measured and reported relative to a reference in delta $(\delta)$ notation:

$$
\delta_{\text {sample }}=1,000\left[\left(R_{\text {sample }} / R_{\text {ref } \left.\left.)^{-1}\right)\right]}\right.\right.
$$

where $R$ is ${ }^{2} \mathrm{H} / \mathrm{H}$ for hydrogen or ${ }^{18} \mathrm{O} /{ }^{16} \mathrm{O}$ for oxygen. Results are reported in units of per mil (parts per thousand or \%o). The reference used for both deuterium and oxygen-18 isotopic ratios is Vienna Standard Mean Ocean Water (VSMOW) (Sacks, 2002), which has $\delta^{2} \mathrm{H}$ and $\delta^{18} \mathrm{O}$ of $0 \%$ by definition.

The relative amounts of ${ }^{2} \mathrm{H}$ and ${ }^{18} \mathrm{O}$ in the environment vary depending on water phase and location, including latitude, elevation, and the distance from the ocean. ${ }^{2} \mathrm{H}$ and ${ }^{18} \mathrm{O}$ preferentially condense out of water because of their greater masses, making rainfall isotopically enriched compared to water vapor in the atmosphere (Sacks, 2002). The lighter and more numerous isotopes of oxygen and hydrogen, ${ }^{1} \mathrm{H}$ and ${ }^{16} \mathrm{O}$, have higher vapor pressures and diffusivities, causing them to preferentially evaporate compared to the heavier isotopes. Consequently, surface water becomes enriched in ${ }^{2} \mathrm{H}$ and ${ }^{18} \mathrm{O}$ compared to water vapor and atmospheric moisture. Rainfall around the world has a consistent relation between $\delta^{2} \mathrm{H}$ and $\delta^{18} \mathrm{O}$, as delineated by the global meteoric water line (GMWL), because of the global balance between evaporation and condensation (Craig, 1961; Sacks, 2002).

In 1999, Sacks (2002) determined the local meteoric water line (LMWL) for west-central Florida by collecting and compositing monthly rainfall samples and then analyzing the samples for $\delta^{2} \mathrm{H}$ and $\delta^{18} \mathrm{O}$. The LMWL represents the ambient variability of $\delta^{2} \mathrm{H}$ and $\delta^{18} \mathrm{O}$ in the rainfall of westcentral Florida from that of the GMWL and seawater. Sacks determined that there was no statistical difference between the GMWL and LMWL in west-central Florida. The LMWL was defined as $\delta^{2} \mathrm{H}=7.73 \delta^{18} \mathrm{O}+11.62$, whereas Craig (1961) defined the GMWL as $\delta^{2} \mathrm{H}=8.0 \delta^{18} \mathrm{O}+10$.

Water influenced by evaporation is offset to the right of the meteoric water line (MWL) when $\delta^{2} \mathrm{H}$ is graphically plotted against $\delta^{18} \mathrm{O}$ because of differences in how the two isotopes fractionate during evaporation (Sacks, 2002). The local evaporation trend line provides useful information as to the sources of water in a watershed. Waters with the longest residence times at land surface plot farthest to the right because they have undergone the most evaporation. Once water recharges to the groundwater system it undergoes little to no additional evaporation and therefore, groundwater maintains the isotopic signature it had at the time of recharge as long as it remains in the groundwater system. Sources of groundwater recharge can be determined by comparing a groundwater sample position on a graph with that of local surface waters and the MWL. Groundwater samples that plot on or near the MWL recharged quickly after deposition, whereas samples that contain isotopically enriched water remained at land surface for a period of time before recharge.

Four age-dating analyses were added to the December 2008 through January 2009 sampling event to better define flow paths within the Lake Panasoffkee groundwater system and to assess if mixing was occurring between shallow and deep groundwater systems. Analyses included carbon-14 $\left({ }^{14} \mathrm{C}\right)$, tritium $\left({ }^{3} \mathrm{H}\right)$, sulfur hexafluoride $\left(\mathrm{SF}_{6}\right)$, and $\mathrm{CFCs}$. The term "age dating" refers not to the age of the water itself, but to the time elapsed since the water recharged the groundwater system.

Carbon-14 is a naturally occurring radioactive isotope of carbon that is created when cosmic ray protons bombard nuclei in the Earth's upper atmosphere. The resultant neutrons, in turn, blast nitrogen atoms, composed of seven protons and seven neutrons, into the radioactive isotope ${ }^{14} \mathrm{C}$, composed of six protons and eight neutrons. ${ }^{14} \mathrm{C}$ is then incorporated into the planetary carbon cycle where the vast majority is incorporated into atmospheric carbon dioxide. All biomass at Earth's surface contains ${ }^{14} \mathrm{C}$ at atmospheric levels, but once 


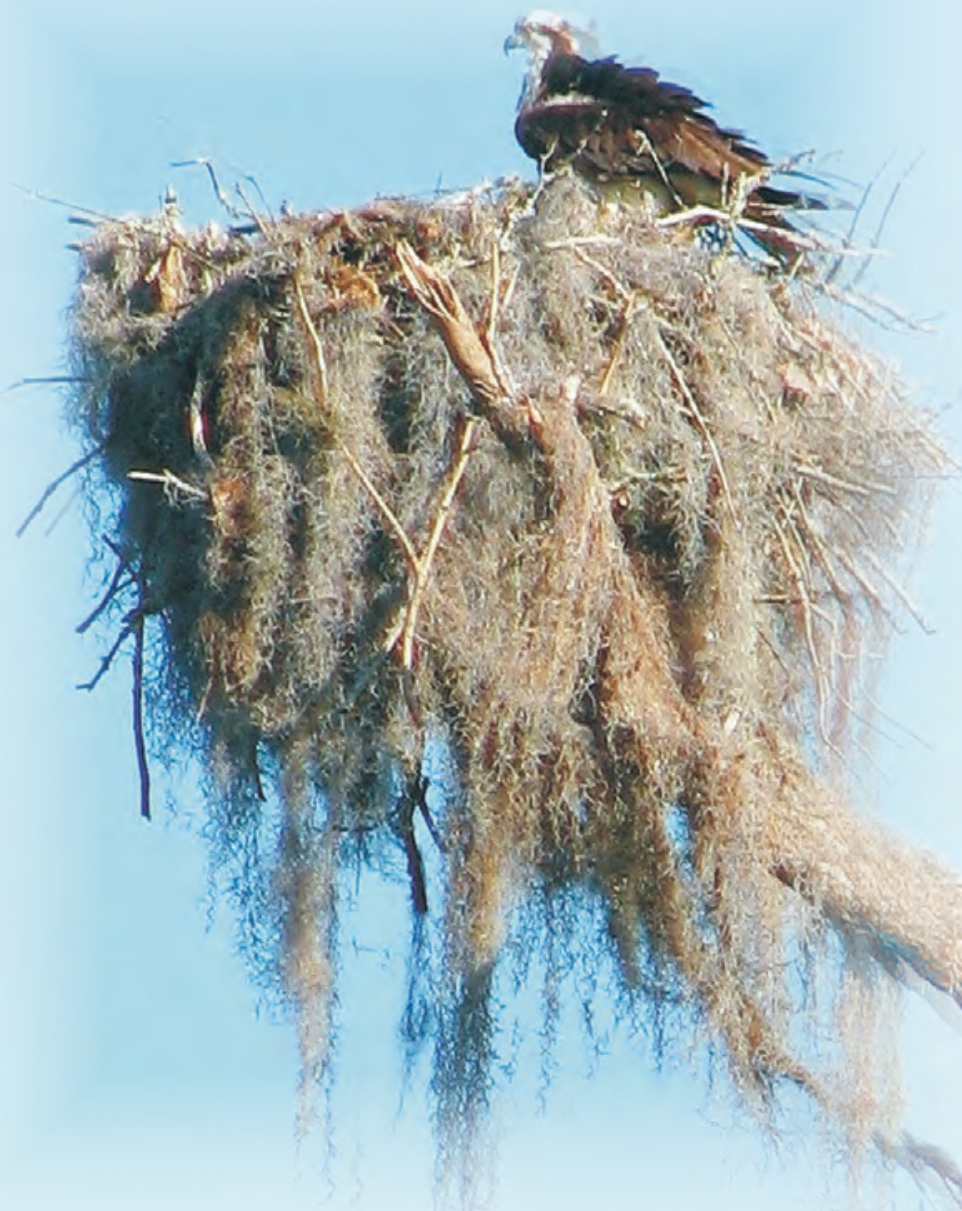

Osprey nest

the ${ }^{14} \mathrm{C}$ drops out of the biological cycle, such as through burial or dissolution in water that recharges an aquifer, it begins to decay. Once the concentration of ${ }^{14} \mathrm{C}$ is measured in a groundwater sample, the time elapsed since recharge can be calculated by knowing the half-life of ${ }^{14} \mathrm{C}$ (5,568 years), and making assumptions about the initial ${ }^{14} \mathrm{C}$ concentration at the time of recharge. For every half-life since the recharge event, the concentration of ${ }^{14} \mathrm{C}$ decreases by half. It is assumed that a "parcel" of water is at equilibrium with the atmospheric concentration of ${ }^{14} \mathrm{C}$ at the time of recharge (Kalin, 2000).

The geochemical mass-balance model NETPATH (Plummer and others, 1991) was used to apply adjustments to the ${ }^{14} \mathrm{C}$ data in the manner of Ingerson and Pearson (1964), Tamers (1975), Fontes and Garnier (1979), and Eichinger (1983). Geochemical reactions, such as dedolomitization, calcium carbonate recrystallization, microbial oxidation of organic matter, and cation exchange reactions, can all lower the ${ }^{14} \mathrm{C}$ activity of dissolved inorganic carbon, leading to unrealistically old apparent radiocarbon ages (Plummer and Sprinkle, 2001). The apparent radiocarbon ages from this study were analyzed using the NETPATH model, and the ${ }^{14} \mathrm{C}$ age data were corrected for geochemical reactions that cause erroneous apparent ages. The model output reflected a range of maximum ${ }^{14} \mathrm{C}$ ages for each water sample.

The primary ${ }^{3} \mathrm{H}$ input to groundwater was from aboveground nuclear testing of hydrogen bombs that began in 1952, although low tritium concentrations are naturally produced in the atmosphere by cosmic radiation. Atmospheric concentrations of ${ }^{3} \mathrm{H}$ peaked between 1962 and 1965 after the ban of above-ground nuclear testing, and have declined since then (University of Miami Tritium Laboratory, 2009). The short half-life of ${ }^{3} \mathrm{H}$ (12.43 years) makes it an ideal tracer of young groundwater (Solomon and Cook, 2000). The ${ }^{3} \mathrm{H}$ isotope is commonly reported in tritium units (TU), where $1 \mathrm{TU}$ is defined as the presence of one tritium atom in $10^{18}$ atoms of hydrogen. If water samples contain concentrations of ${ }^{3} \mathrm{H}$ above naturally occurring background concentrations, typically 5 to $10 \mathrm{TU}$, then at least a fraction of the sample was recharged after 1952. In this report, groundwater recharged after 1952 is referred to as "young" groundwater, whereas "old" groundwater was recharged prior to 1952.

Sulfur hexafluoride is a trace atmospheric gas that is mostly anthropogenic in origin (Busenberg and Plummer, 2000). The primary use of $\mathrm{SF}_{6}$ is in the production of high voltage electrical switches. Substantial industrial usage began in the 1960s and the atmospheric concentration of $\mathrm{SF}_{6}$ has risen steadily, and at known rates, ever since. Atmospheric moisture equilibrates to the concentration of $\mathrm{SF}_{6}$ in air before falling back to the Earth as precipitation. Water recharging to groundwater maintains the concentration of $\mathrm{SF}_{6}$ present in the atmosphere at the time of recharge, which makes it a useful tool for dating groundwater that has recharged in the last 35 years. $\mathrm{SF}_{6}$ also is conservative chemically, meaning it reacts little with other compounds in the environment (Plummer and Busenberg, 2000; Reston Chlorofluorocarbon Laboratory, 2009).

Chlorofluorocarbons also were used to age-date selected samples of groundwater. CFCs are anthropogenic in origin and were widely used as refrigerants, solvents, and in plastic foam production until being banned in the United States in 1996 because of the damage they cause to the Earth's ozone layer. Since the 1996 ban, atmospheric CFC concentrations have declined. Similar to $\mathrm{SF}_{6}, \mathrm{CFC}$ s are useful for dating young groundwater because their concentrations in the atmosphere rose steadily and at known rates after their introduction, and because of their conservative behavior in the subsurface. Once water enters the groundwater system, the concentration of CFCs remains constant, effectively tagging the parcel of water with the date of recharge. By comparing the amount of each CFC compound dissolved in a groundwater sample with a plot of yearly atmospheric CFC concentration, a date of recharge can be derived (Plummer and Busenberg, 2000; Reston Chlorofluorocarbon Laboratory, 2009).

All of the water samples analyzed for $\mathrm{SF}_{6}$ and CFCs also were analyzed for dissolved gas content. The low solubility of $\mathrm{SF}_{6}$ and CFCs in water requires that excess air be accounted for in order to calculate accurate apparent sample ages. Excess air is introduced when air trapped in the unsaturated zone dissolves into groundwater during a rapid rise of the water table in the surficial aquifer. This introduces $\mathrm{SF}_{6}$ in excess of atmospheric concentration and makes the apparent age of samples appear erroneously young (Reston Chlorofluorocarbon Laboratory, 2009). 


\section{Hydrogeology}

The hydrogeologic units of interest to this study are the surficial aquifer, intermediate confining unit, and the Floridan aquifer system, which includes the Upper Floridan aquifer, the middle confining units I and II, and the Lower Floridan aquifer (fig. 15). Well data used to construct the hydrogeologic cross sections in figures 16 and $17 A-B$ are contained in table 5 . The cross sections schematically depict the orientation of the hydrogeologic units. Cross sections are used because they illustrate trends in the study area's hydrogeology that are not readily apparent in figure 15 . Detailed structural maps of the area of these sections are not available, which is why substantially less is known about the lateral extent and vertical position of some of the units. Locally, the Upper Floridan aquifer is comprised primarily of the Ocala Limestone and the upper part of the Avon Park Formation. The Ocala Limestone is highly transmissive because of secondary porosity from karstification, whereas the transmissivity of the dolomitic limestone of the Avon Park Formation mostly depends on the extent of fracturing.

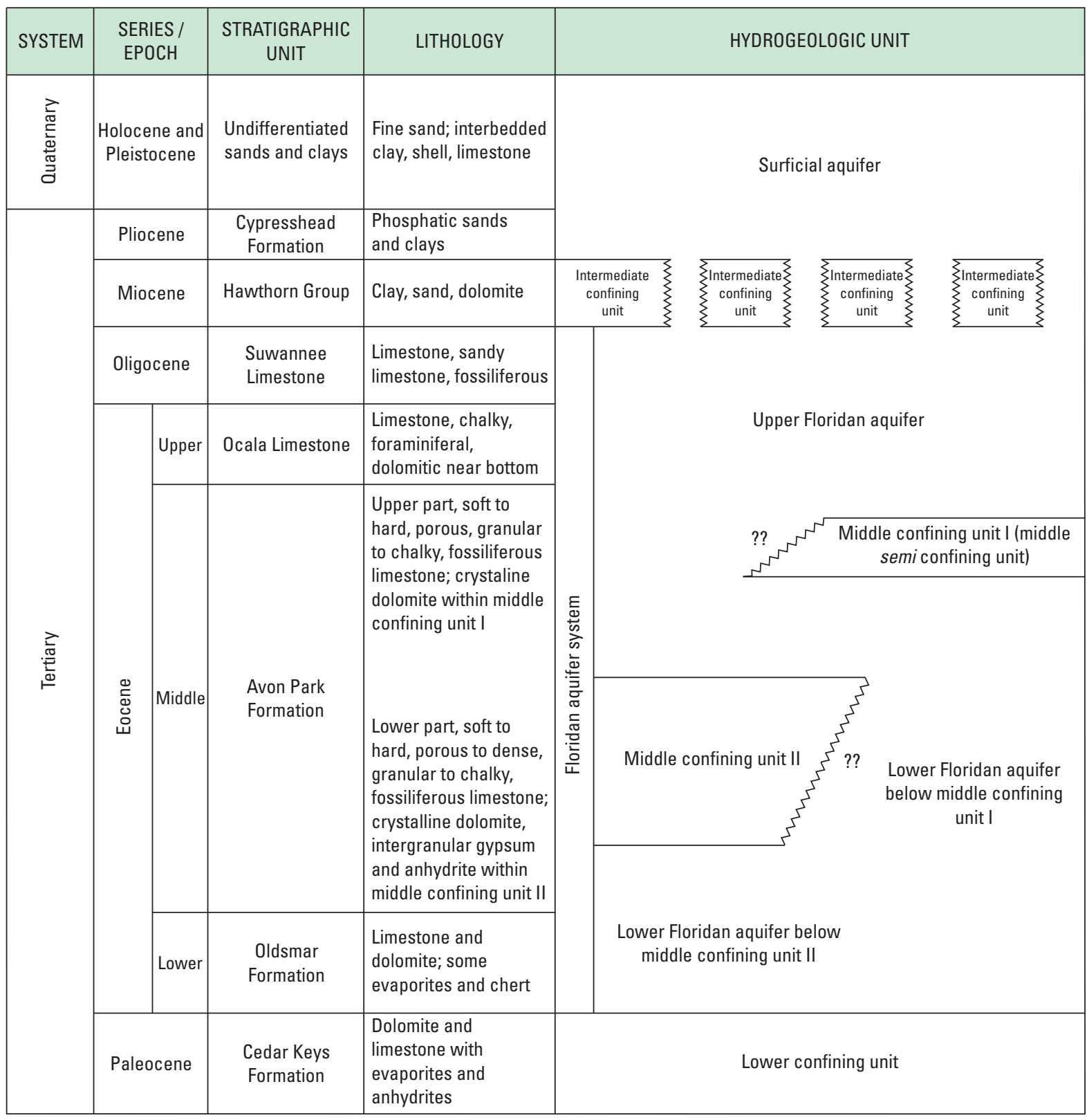

Figure 15. Relation of stratigraphic and hydrogeologic units in the Lake Panasoffkee watershed (Modified from Ryder, 1985; Sacks, 1996; and O'Reilly and others, 2002). The intermediate confining unit and the Suwannee Limestone are of limited areal extent in the study area. 


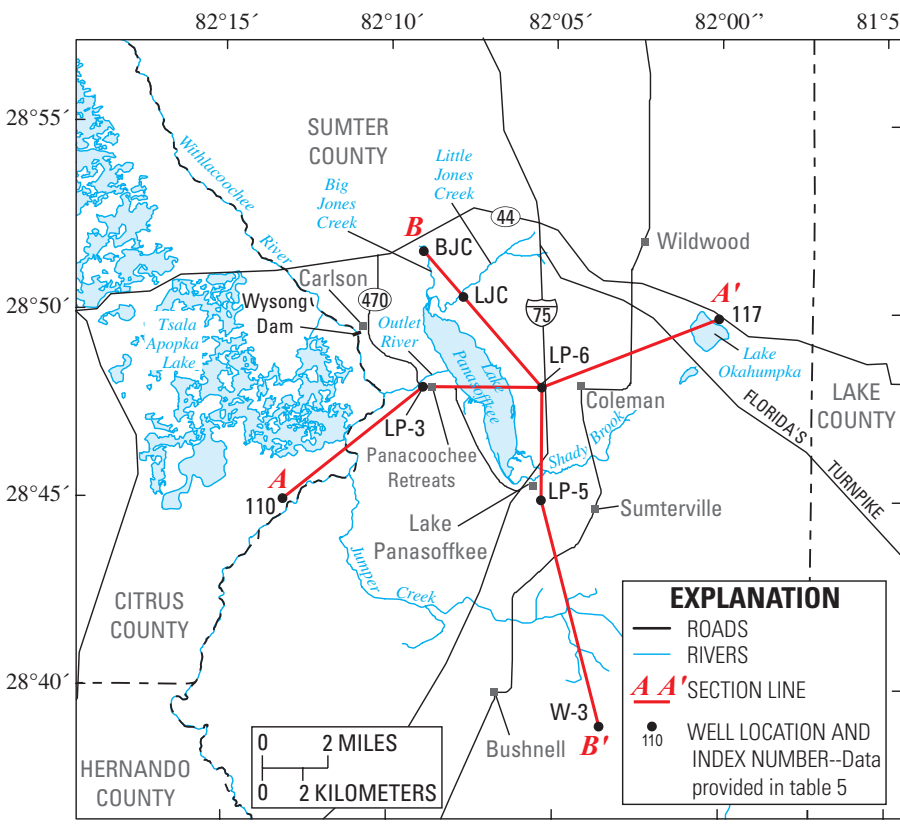

Base modified from U.S. Geological Survey digital data; 1:2,000,000, 1998.

Universal Transverse Mercator projection, Zone 17 North

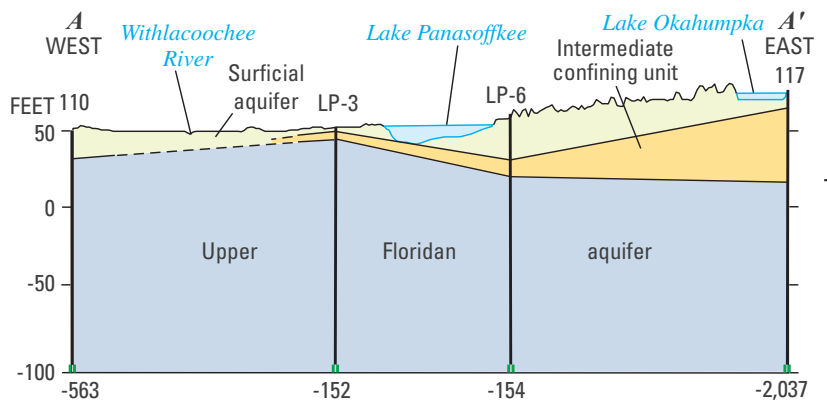

\section{EXPLANATION}

-... HYDROGEOLOGIC UNIT CONTACT DASHED WHERE INFERRED 110 NUMBER AT TOP IS WEL NAME; NUMBER AT -563 BOTTOM IS WELL
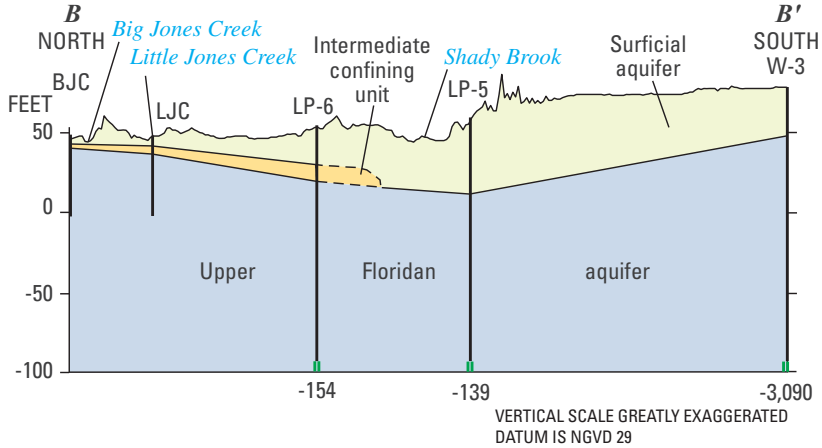

Figure 16. Hydrogeologic cross sections of the shallow groundwater system near Lake Panasoffkee. 


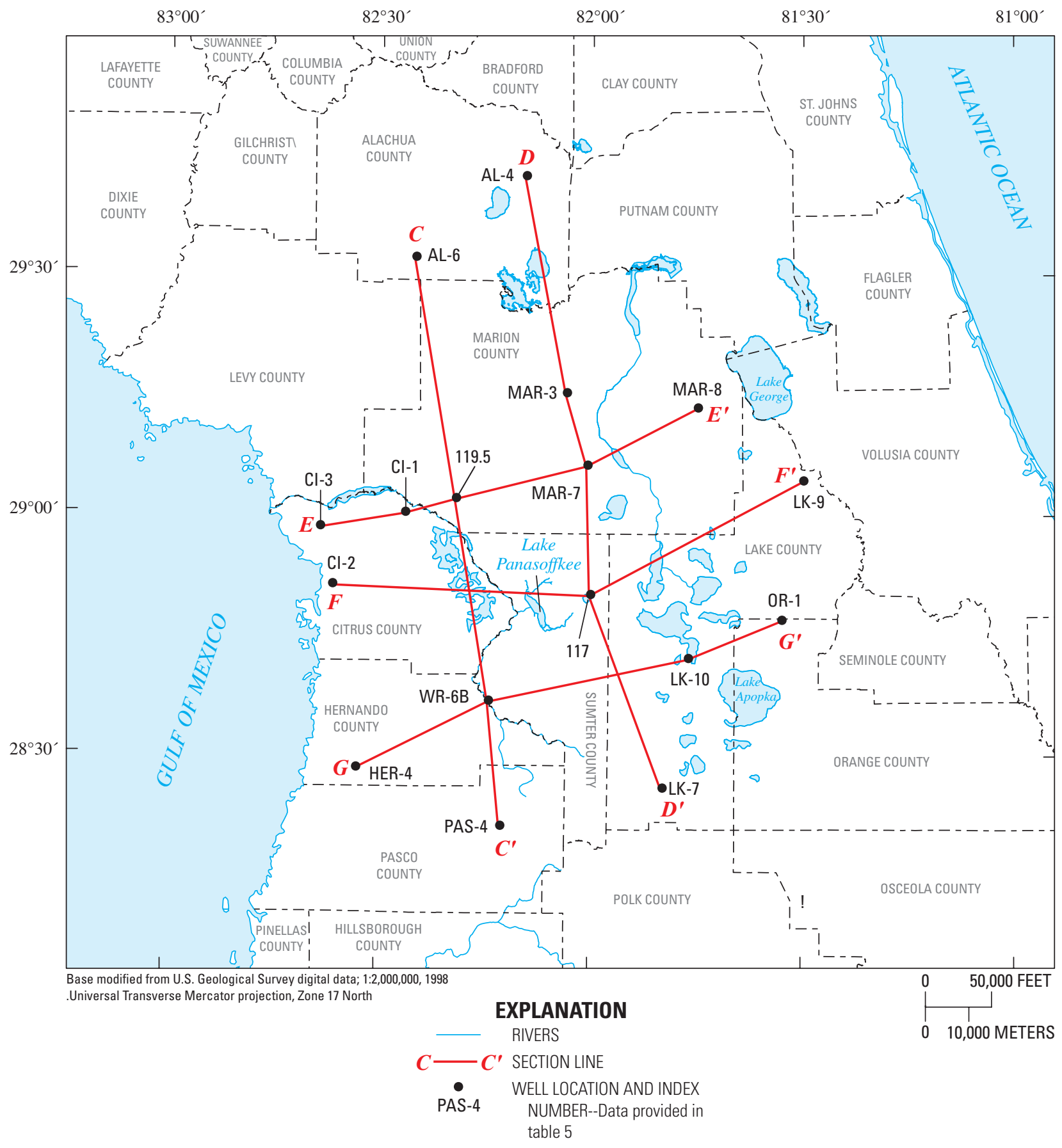

Figure 17A. Location of hydrogeologic section lines of the deep groundwater system in the region surrounding Lake Panasoffkee. 

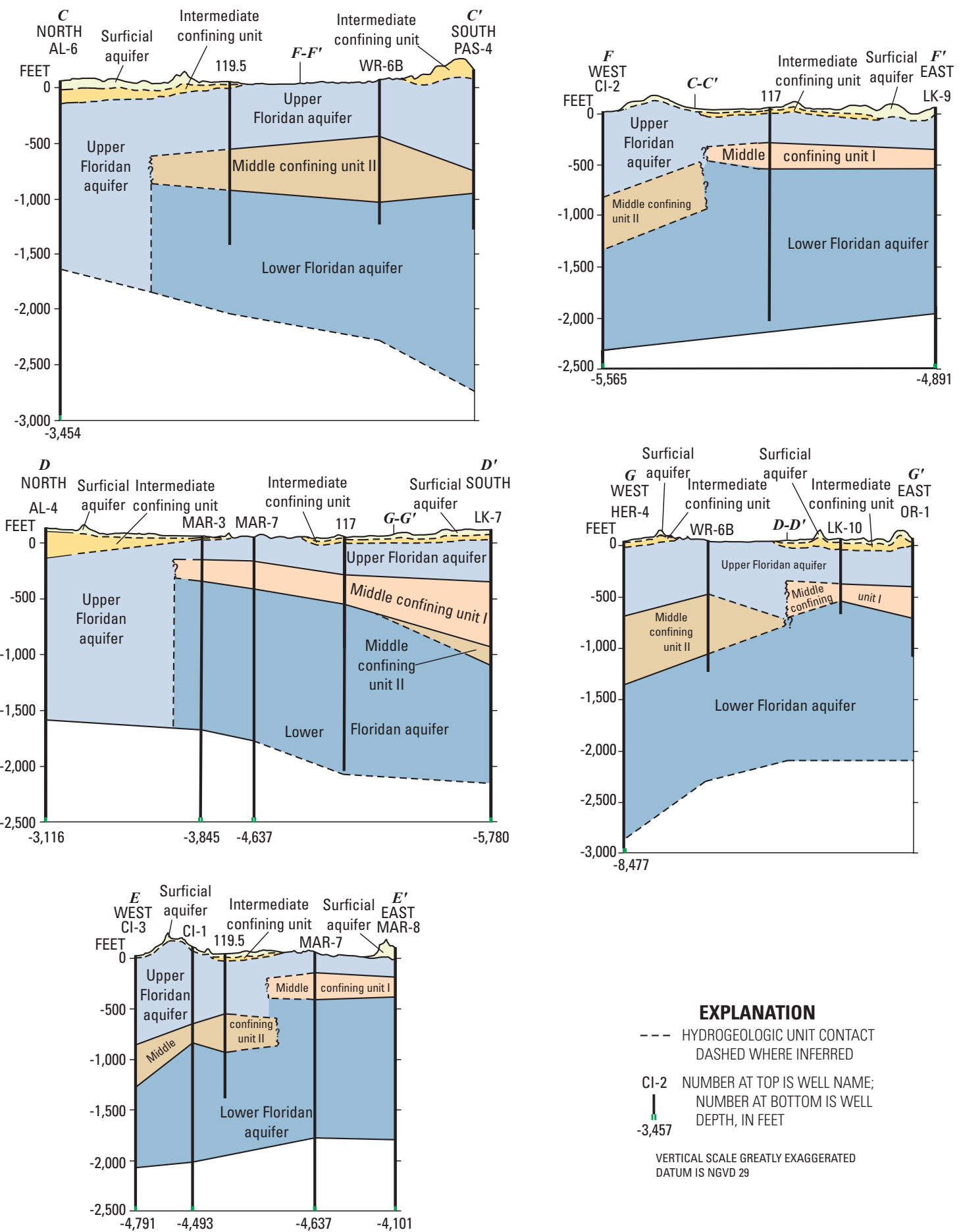

\section{EXPLANATION}

- - HYDROGEOLOGIC UNIT CONTACT

DASHED WHERE INFERRED

CI-2 NUMBER AT TOP IS WELL NAME:

I NUMBER AT BOTTOM IS WELL

$-3,457$ DEPTH, IN FEET

VERTICAL SCALE GREATLY EXAGGERATED DATUM IS NGVD 29

Figure 17B. Hydrogeologic cross sections of the deep groundwater system in the region surrounding Lake Panasoffkee. 


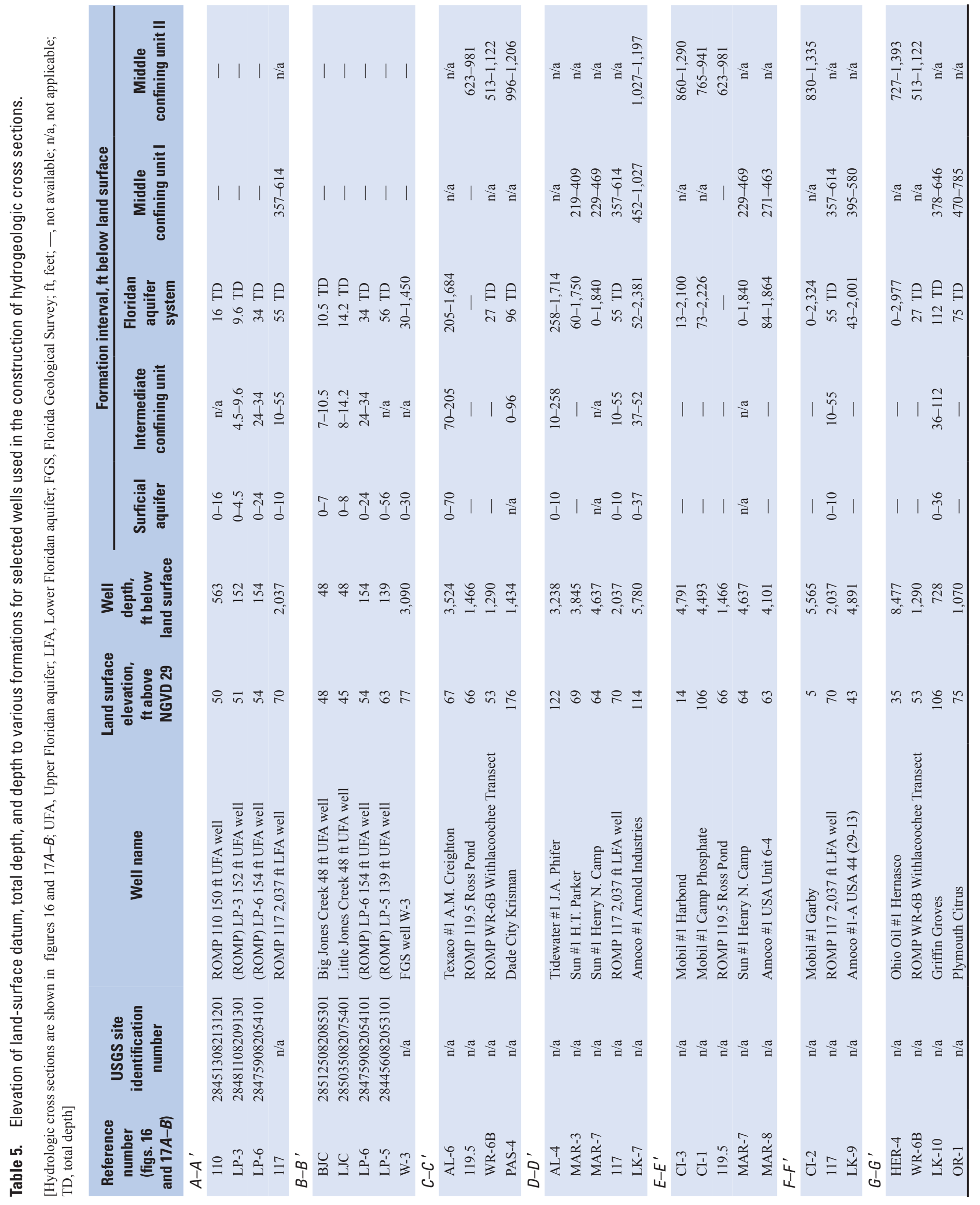




\section{Surficial Aquifer}

The surficial aquifer is the uppermost hydrogeologic unit in the study area (fig. 15). It is an unconfined aquifer, consisting of a thin layer of undifferentiated fine sand interbedded with clay, shell, and limestone, overlying a thick sequence of Tertiary carbonate rocks that form the Floridan aquifer system (Campbell, 1989). Within the study area, the surficial aquifer tends to be thickest near the uplands and thinnest in low-lying areas (Trommer and others, 2009). The most recent sediments in the surficial aquifer are undifferentiated Holocene and Pleistocene quartz sands, clayey sands, and clay (Campbell, 1989). Surficial aquifer deposits were between 4.5 and $56 \mathrm{ft}$ in thickness in seven core samples collected by the SWFWMD in the study area. The surficial aquifer was $16 \mathrm{ft}$ thick or less at wells GW5, GW7, GW19, and GW24, $24 \mathrm{ft}$ thick at well GW37, and $56 \mathrm{ft}$ thick at wells GW31 and GW35 (fig. 11 and table 3). In parts of the study area, the surficial aquifer may be missing entirely where the underlying limestone units crop out at land surface.

The surficial aquifer is recharged by rainfall that infiltrates the unsaturated zone and moves down to the water table. Throughout this study, the water table in the Lake Panasoffkee watershed was generally within $20 \mathrm{ft}$ of land surface, and during brief wet periods it was at or near land surface in low-lying areas. The elevation of the water table fluctuates seasonally based on rainfall patterns, evapotranspiration, and the stage of nearby surface-water bodies (Miller, 1986). The lack of a continuous confining unit between the surficial aquifer and the Upper Floridan aquifer in the study area allows water in the surficial aquifer to recharge the Upper Floridan aquifer directly. In those areas where there is confinement, water percolates downward through the unsaturated zone to the water table and then flows laterally along the top of the intermediate confining unit until it either discharges to a surface-water feature or recharges the Upper Floridan aquifer if a pathway through the intermediate confining unit is reached (Miller, 1986).

The transmissivity of the surficial aquifer varies in west-central Florida depending on its saturated thickness and lithology (Ryder, 1985). No aquifer tests have been performed in the surficial aquifer within the study area, but limited tests performed outside the study area within the SWFWMD indicate that transmissivity is typically low compared to that of the underlying Upper Floridan aquifer. Surficial aquifer test results either performed or gathered by the SWFWMD from various agencies and consulting firms in west-central Florida indicate that transmissivity varies from 8 to $5,348 \mathrm{ft}^{2} / \mathrm{d}$ when the thickness of the aquifer is $55 \mathrm{ft}$ or less (Robert Peterson, Southwest Florida Water Management District, written commun., 2010).

Regionally, the phosphatic sands and clays of the Pliocene-age Cypresshead Formation are found below the undifferentiated sands and clays of the surficial aquifer, and above the clayey Hawthorn Group. Throughout its spatial extent, the permeable sands of the Cypresshead Formation act as part of the surficial aquifer (Scott, 2001). The Cypresshead Formation was identified in the study area west of Lake Panasoffkee in a core sample collected at ROMP LP-3 (GW19) by the SWFWMD (fig. 11 and table 3) at a depth of $4.5 \mathrm{ft}$ below land surface and with a thickness of $5.1 \mathrm{ft}$. Campbell (1989) determined that the Cypresshead Formation is rarely present within the study area.

\section{Intermediate Confining Unit}

Where present in northern west-central Florida, the clays of the Hawthorn Group form the intermediate confining unit between the surficial aquifer and the Upper Floridan aquifer. Within the Lake Panasoffkee watershed, the clay, sand, and dolomite of the Miocene Hawthorn Group are discontinuous (Scott, 2001) due to weathering, erosion, and breaching from karst activity. Hawthorn Group clays were present in core samples collected in the study area at sites GW19 and GW37 (fig. 11 and table 3). Clays were present in these samples 4.5 to $24 \mathrm{ft}$ below land surface and were 5.1 to $10 \mathrm{ft}$ thick, respectively. Clay was not found at site GW31, and only a thin clay horizon was found at sites GW5, GW7, GW24 and GW35.

\section{Upper Floridan Aquifer}

The Upper Floridan aquifer is present throughout most of Florida and is composed of high porosity limestones. In the study area, the aquifer lies beneath the surficial aquifer and is semiconfined or unconfined because of the incomplete coverage of the Hawthorn Group clays. The Oligocene age Suwannee Limestone is the uppermost limestone found in the region, but it is not areally extensive and is not an important aquifer unit in the study area. Remnant boulders of Suwannee Limestone are common in the southern part of Sumter County, and pockets of this unit are present in low spots in the top of the underlying Ocala Limestone throughout the county (Campbell, 1989). However, the Suwannee Limestone has mostly been eroded away within the study area.

The Ocala Limestone is of late Eocene age and is the uppermost unit of the Upper Floridan aquifer within the study area where the Suwannee Limestone is absent. The chalky, fossiliferous Ocala Limestone is porous and highly karstified, with some dolomite near the base of the unit. The top of the Ocala Limestone was from 9.6 to $56 \mathrm{ft}$ below land surface within the study area at well sites GW5, GW7, GW19, GW24, GW31, GW35, and GW37 (fig. 11 and table 3). The Ocala Limestone was from 34 to $84 \mathrm{ft}$ thick at the four sites where a complete core sample was recovered and where the well was drilled to sufficient depth to fully penetrate the formation (GW19, GW24, GW35, and GW37).

Beneath the Ocala Limestone is the Avon Park Formation of middle Eocene age. Regionally, the top of the Avon Park Formation lies at about 150 to $500 \mathrm{ft}$ below land surface, and the formation has a thickness of about 950 to $1,280 \mathrm{ft}$ 
(Campbell, 1989). In the study area, cores collected at ROMP sites GW19, GW24, GW31, GW35, and GW37 indicate that the top of the formation is from 44.5 to $140 \mathrm{ft}$ below land surface (fig. 11 and table 3), but none of the wells fully penetrate the formation. The upper part of the Avon Park Formation is soft to hard, porous, granular to chalky, fossiliferous limestone and dolostone, whereas the lower part of the Avon Park Formation is porous to dense and has more dolostone than limestone. The Avon Park Formation spans both the Upper and Lower Floridan aquifers, depending on the presence or absence of confining units within the formation. When no middle confining units are present, all of the Avon Park Formation is considered part of the Upper Floridan aquifer (Miller, 1986). The Avon Park Formation is the deepest geologic unit in the region commonly used for public water supply because waters in deeper formations are often highly mineralized.

A lack of confinement and downward head differences between the surficial and Upper Floridan aquifers allows water from the surficial aquifer to recharge the Upper Floridan aquifer in the southwestern and northeastern parts of the study area (Aucott, 1988). Karst features in the study area, such as sinkholes, fractures, and conduits, also can serve as direct pathways for recharge between the land surface and the Upper Floridan aquifer. Bush and Johnston (1988) estimated that transmissivity ranges from about 50,000 to $1,000,000 \mathrm{ft}^{2} / \mathrm{d}$ in the Upper Floridan aquifer in Sumter County, with the lowest transmissivity values found in the southeast near the Lake Upland, and the highest values found in the northeast under the Sumter Upland (figs. 3 and 18). Aquifer tests performed by the SWFWMD at site GW35 (fig. 11 and table 3) within the study area indicated Upper Floridan aquifer transmissivities of about $9,100 \mathrm{ft}^{2} / \mathrm{d}$, but transmissivity data collected from 12 other aquifer tests conducted in Sumter or surrounding counties ranged from 28,000 to $1,850,000 \mathrm{ft}^{2} / \mathrm{d}$ (Robert Peterson, Southwest Florida Water Management District, written commun., 2010). Unconfined or semiconfined areas of the Upper Floridan aquifer typically have higher aquifer transmissivities than areas that are confined (Johnston and Bush, 1988). The Upper Floridan aquifer in unconfined or semiconfined areas undergoes greater chemical weathering than in confined areas because acidic near-surface water and rain reaches the aquifer faster in these areas and therefore dissolves more carbonate. Those areas with the highest aquifer transmissivities typically have extensively developed solution features that act as secondary pathways for the flow of water. Secondary porosity is more important than primary porosity to increasing the transmissivity of the Floridan aquifer system (Miller, 1986). The karstic Ocala Limestone is more transmissive than the Avon Park Formation because of extensive secondary porosity. The many springs found in the study area result from this secondary porosity and indicate that a large volume of water can be transported through these pathways.

\section{Middle Confining Units I and II}

Two distinct confining units within the Avon Park Formation in central Florida separate the Floridan aquifer system into the Upper Floridan and Lower Floridan aquifers (Miller, 1986). Although middle confining unit I lies primarily to the east of the Lake Panasoffkee area, its western extent is poorly defined throughout its range because few wells in the area extend to this depth. Middle confining unit I, the leakiest of the eight middle confining units within the Floridan aquifer system, is composed of soft, less permeable crystalline dolomite within the Avon Park Formation that inhibits flow, but does not prevent it (Miller, 1986). The lithology of middle confining unit I does not vary greatly from that of the Upper and Lower Floridan aquifers above and below it, except that there is secondary mineralization of the pore spaces within the unit, which slightly reduces the permeability. Differences in water levels between wells installed above and below middle confining unit I confirm its definition as a confining unit (O'Reilly and others, 2002). The top of middle confining unit I is $357 \mathrm{ft}$ below land surface about $7 \mathrm{mi}$ east of Lake Panasoffkee at ROMP 117, where the unit is $257 \mathrm{ft}$ thick (fig. 19) (Jason LaRoche, Southwest Florida Water Management District, written commun., 2009).

Middle confining unit II is less permeable than middle confining unit I, and is composed of hard, crystalline dolomitic limestone and gypsiferous dolomite of the Avon Park Formation. Gypsum and anhydrite have largely filled the pore spaces of the dolomite matrix composing middle confining unit II, resulting in low permeability (Miller, 1986). This unit is present primarily west of Lake Panasoffkee, although its eastern boundary is not well defined because few wells extend deep enough to penetrate this unit. Middle confining unit II was not found at ROMP 117 east of Lake Panasoffkee where middle confining unit I was found. Hydraulic data indicate that middle confining unit II is essentially non-leaky (Miller, 1986). At ROMP WR-6B, about 15 mi southwest of Lake Panasoffkee (fig. 19), the top of middle confining unit II was $513 \mathrm{ft}$ below land surface, and the unit was $609 \mathrm{ft}$ thick (Jason LaRoche, Southwest Florida Water Management District, written commun., 2009). At ROMP 119.5, about 20 mi northwest of Lake Panasoffkee (fig. 19), the top of middle confining unit II was $623 \mathrm{ft}$ below land surface, and the unit was $358 \mathrm{ft}$ thick (Jason LaRoche, Southwest Florida Water Management District, written commun., 2009). Middle confining unit I was not found at ROMP WR-6B nor ROMP 119.5 .

At ROMP 102.5, located about $10 \mathrm{mi}$ south of Lake Panasoffkee (fig. 19), both middle confining units I and II were found. The top of middle confining unit I lies $431 \mathrm{ft}$ below land surface and the unit is $119 \mathrm{ft}$ thick, whereas the top of middle confining unit II lies $792 \mathrm{ft}$ below land surface and the unit is $323 \mathrm{ft}$ thick. Two zones of slightly higher permeability found within middle confining unit II at ROMP 102.5 


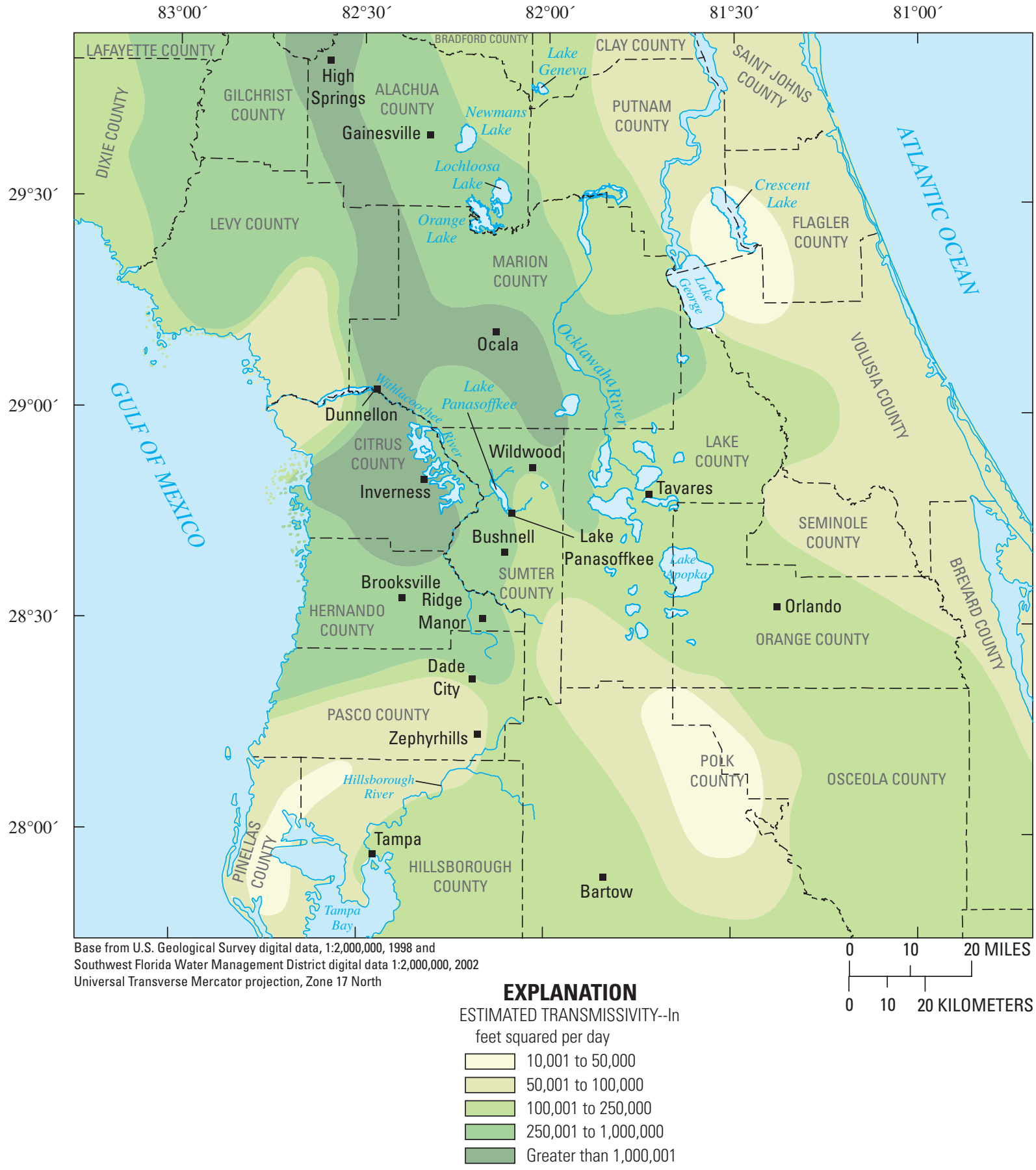

Figure 18. Regional transmissivity of the Upper Floridan aquifer (from Bush and Johnston, 1988). 
ROMP 119.5

FEET (20 miles northwest of Lake Panasoffkee)

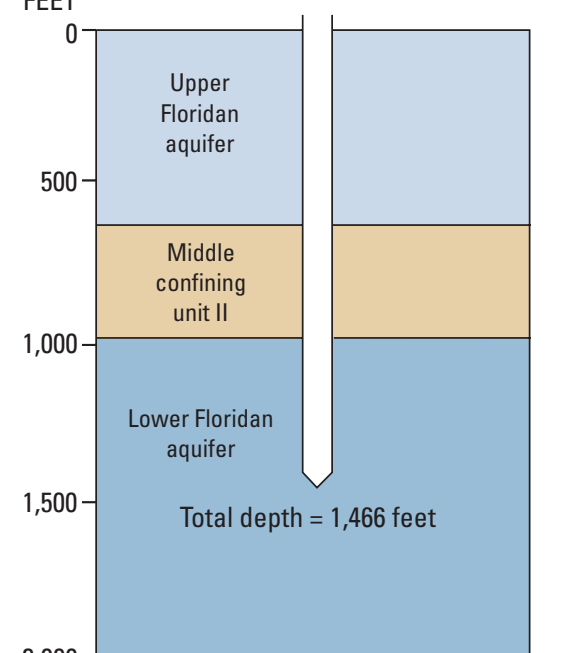

ROMP 117

miles west of Lake Panasoffkee)

FEET
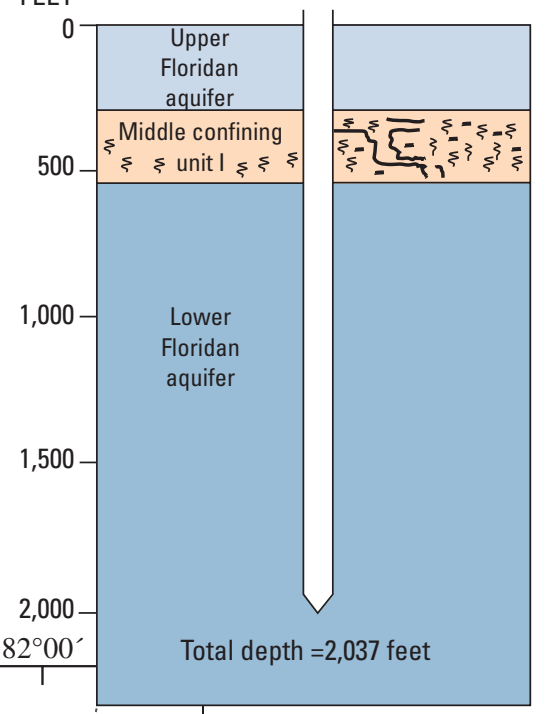

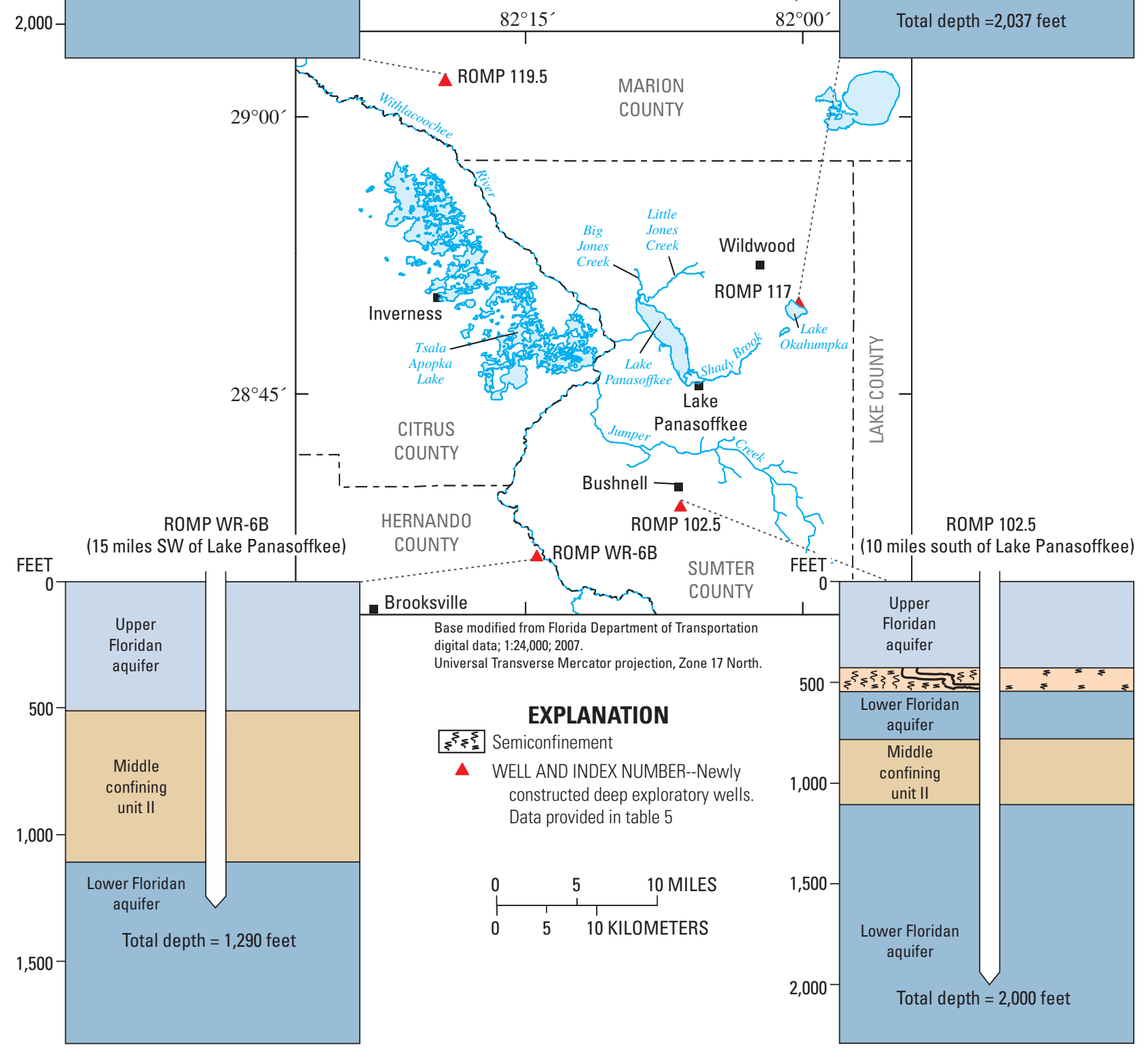

Figure 19. Hydrostratigraphy at four wells installed in the Lower Floridan aquifer near Lake Panasoffkee. 
contained water of lower mineral content than in the confining unit above and below those zones. This indicates that this site is located near the eastern extent of middle confining unit II.

Recent drill coring records by the SWFWMD for ROMP sites 117, WR-6B, 119.5, and 102.5 indicate that the westward extent of middle confining unit II defined in Miller (1986) was originally overestimated, because only middle confining unit I is present at ROMP 117 rather than both units I and II based on Miller's (1986) maps. A reinterpretation of the overlapping area between the two confining units is shown by the dashed line in figure 20. The eastern edge of middle confining unit II was simply shifted to the west so that it lies slightly west of ROMP 117. ROMP 119.5 and WR-6B cores confirm that only middle confining unit II is present at those locations, whereas ROMP 102.5 cores confirm that overlap of the middle confining units exists at that location. Further drilling would be required to more precisely determine the location of middle confining units I and II in this area.

\section{Lower Floridan Aquifer}

In the study area, the Lower Floridan aquifer includes the lower parts of the Avon Park Formation, the Oldsmar Formation, and the upper part of the Cedar Keys Formation. The Lower Floridan aquifer is confined at the base by the lower confining unit within the Cedar Keys Formation (fig. 15). The top of the early Eocene age Oldsmar Formation is about $1,450 \mathrm{ft}$ below land surface, and the formation is 600 to $800 \mathrm{ft}$ thick within Sumter County (Campbell, 1989). The Oldsmar Formation is composed of dolomite and limestone, with variable porosity and microcrystalline to medium crystalline structure with some evaporites and chert (Vernon, 1951; Campbell, 1989). The Cedar Keys Formation, which underlies the Oldsmar Formation in the study area, is Paleocene in age and is mostly composed of microcrystalline to finely crystalline dolomitized limestone with variable quantities of evaporites and anhydrites. The top of the Cedar Keys Formation ranges from about 1,800 to 2,200 ft below land surface, and the unit is between 700 and $1,000 \mathrm{ft}$ thick in Sumter County (Vernon, 1951; Campbell, 1989).

The recent exploratory drilling by the SWFWMD at ROMP 117 indicated that the top of the Lower Floridan aquifer below middle confining unit I was $614 \mathrm{ft}$ below land surface. At ROMP sites 119.5 and WR-6B (fig. 19), the top of the Lower Floridan aquifer below middle confining unit II was $981 \mathrm{ft}$ below land surface and 1,122 ft below land surface, respectively (Jason LaRoche, Southwest Florida Water Management District, written commun., 2009). Tests of basic water-quality constituents such as chloride, sulfate, and specific conductance at ROMP 117 (fig. 19) indicated that potable water was available to a depth of at least $1,850 \mathrm{ft}$ below land surface in the Lower Floridan aquifer below middle confining unit I; however, non-potable water was found in the Lower Floridan aquifer below middle confining unit II at ROMP 119.5 and ROMP
WR-6B. Potable water generally contains less than $250 \mathrm{mg} / \mathrm{L}$ of chloride and sulfate, and has a specific conductance less than $1,000 \mu \mathrm{S} / \mathrm{cm}$. One possible explanation for the difference in water quality between these well sites is the difference in the permeability of the middle confining units above the Lower Floridan aquifer. Middle confining unit I, which is more permeable, allows more interaction between the Lower Floridan aquifer and the overlying freshwater in the Upper Floridan aquifer. At ROMP 117, the greater interaction has helped flush out the minerals that degrade water quality from the Lower Floridan aquifer. At ROMP 119.5 and WR-6B, however, middle confining unit II is less permeable and, therefore, groundwater flow is much slower, resulting in less flushing of the Lower Floridan aquifer below middle confining unit II (Miller, 1986; O'Reilly and others, 2002).

The hydrostratigraphy at ROMP 102.5 (fig. 19), where both confining units are present, is more complicated than at the Lower Floridan wells discussed earlier (ROMP 117, ROMP 119.5, and ROMP WR-6B). Below middle confining unit I, an upper section of the Lower Floridan aquifer extends from $550 \mathrm{ft}$ below land surface to $792 \mathrm{ft}$ below land surface; the latter depth corresponds to the top of middle confining unit II (Jason LaRoche, Southwest Florida Water Management District, written commun., 2010). Water quality, based on chloride, sulfate, and specific conductance data, degraded with depth in the Lower Floridan aquifer between middle confining units I and II, and eventually became non-potable between 600 and $700 \mathrm{ft}$ below land surface. However, water quality began to improve with depth about half-way through middle confining unit II between 900 and 1,000 ft below land surface. A lower section of the Lower Floridan aquifer was found at $1,115 \mathrm{ft}$ below land surface, and water quality in this section continued to improve with depth until a zone of evaporitic, low-permeability rock was reached at 1,391 ft below land surface. Below this level, water quality degraded with depth to the base of this zone at $1,543 \mathrm{ft}$ below land surface. Below $1,543 \mathrm{ft}$, water quality quickly improved with depth to the point of potability and remained potable until at least $2,000 \mathrm{ft}$ below land surface. Drilling at ROMP 102.5 was still underway as of March 2010. Even with the limited data available, it is clear that the presence or absence of the two middle confining units has a substantial effect on the distribution and availability of potable groundwater in the study area.

\section{Groundwater Levels, Contributing Areas, and Differences in Head}

Regional groundwater flow in the Upper Floridan aquifer originates from a potentiometric high in the center of the state in the Lake and Polk Uplands (figs. 3 and 21), and moves northwestward across Lake and Sumter Counties. A second regional groundwater-flow system, beginning at the potentiometric high located in the Northern Highlands (figs. 3 and 21), flows southward from north-central Florida toward the study area. These two regional groundwater-flow systems merge 


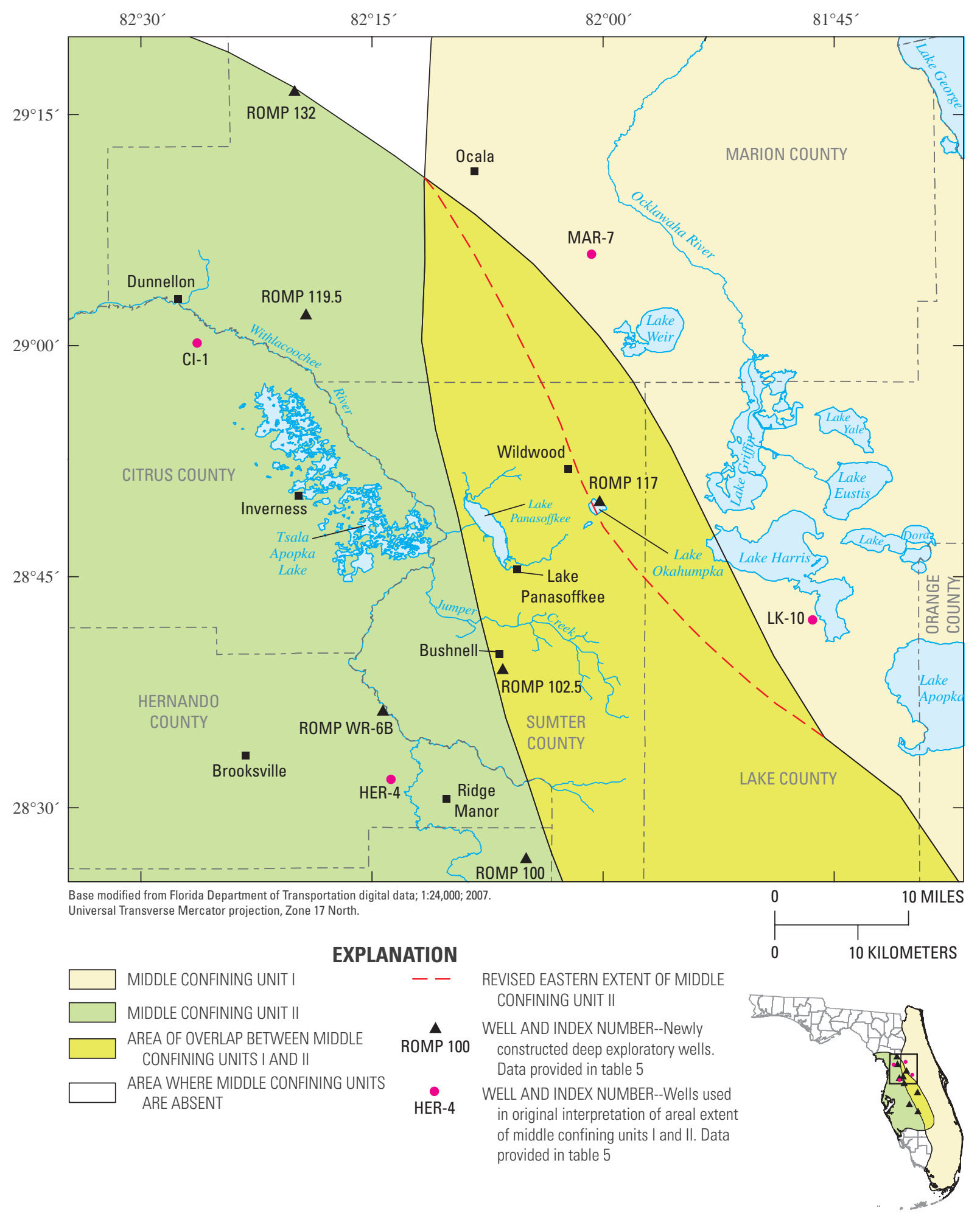

Figure 20. Areal extent of middle confining units I and II near the Lake Panasoffkee study area as interpreted by Miller (1986) with reinterpretation using new hydrogeologic information. Inset shows areal extent of middle confining units I and II in Florida according to Miller (1986). 


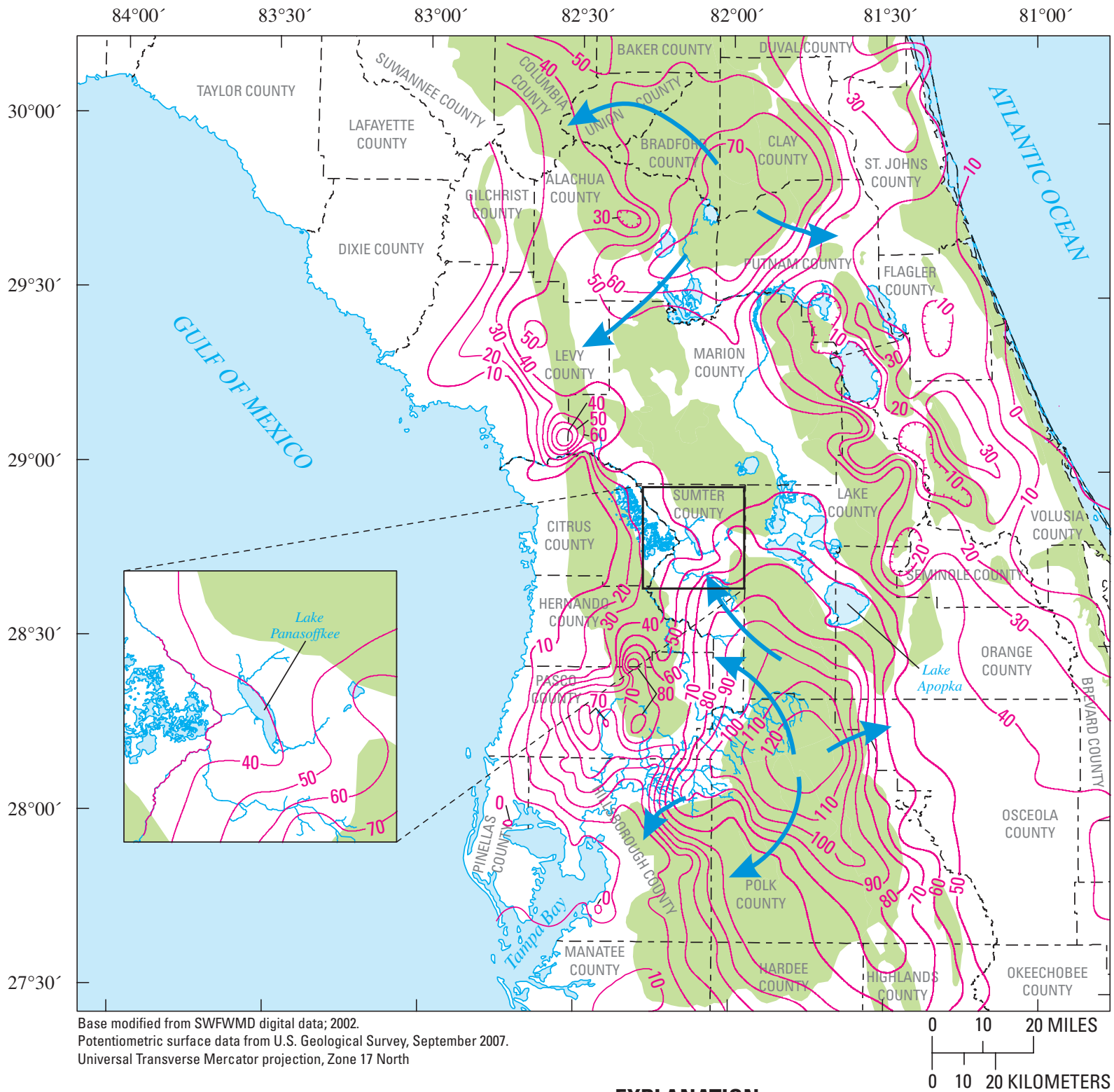

\section{EXPLANATION}

UPLAND AND RIDGE PHYSIOGRAPHIC REGIONS

-60- POTENTIOMETRIC CONTOUR--Shows elevation at

which water level would have stood in tightly cased wells Hachures indicate depression. Contour interval 10 feet. Datum is NGVD 29

4 DIRECTION OF REGIONAL GROUNDWATER FLOW

Figure 21. Regional groundwater flow system in the Upper Floridan aquifer, September 2007 (from Kinnaman and Dixon, 2008; Ortiz, 2008b). 
in central Marion County where the potentiometric surface of the Upper Floridan aquifer flattens out because of high aquifer transmissivities reflected by the large volume of spring discharge in that area. Lake Panasoffkee is located at the northern end of the southern potentiometric high, near where flow from both the northern and southern potentiometric highs turns westward toward the coast.

The area that contributed groundwater to Lake Panasoffkee covered an average area of $192 \mathrm{mi}^{2}$ during the study period and extends about $15 \mathrm{mi}$ southeast and about $5 \mathrm{mi}$ northeast of Lake Panasoffkee. The area is roughly oval in shape (figs. 22 and 23) and was defined from the regional potentiometric-surface maps of the Upper Floridan aquifer (Ortiz, 2008a, b, c, and 2009) and from the detailed potentiometric-surface maps created as part of this study. The potentiometric surface was defined using a simple graphical method similar to the way a topographic basin is defined. Water flows from the highest point in the groundwater basin and the boundaries of the contributing area and flow lines are all perpendicular to the lines of equal potential (head). Using this method to define the groundwater contribution area probably overestimates the actual area that contributes groundwater to Lake Panasoffkee because some groundwater farther from the lake probably flows vertically to recharge deeper parts of the flow system rather than laterally.

Groundwater-level data collected in May 2007 and 2008 (figs. $22 A$ and $23 A$ ) were used to generate potentiometricsurface maps of the Upper Floridan aquifer at the end of the historic annual dry season when water levels are usually low, whereas the September 2007 and 2008 maps (figs. 22B and $23 B$ ) illustrate the potentiometric surface at the end of the annual wet season when water levels are usually high. Longterm water-level data indicate that, on average, groundwater levels are lowest in Florida in May because winter and spring are usually the driest seasons of the year, whereas September typically has the highest groundwater levels following the wet summer months when rainfall and tropical activity are highest.

The groundwater-level data used to draw all four maps during the study period were collected during drought conditions. The May 2007 map (fig. 22A) represents peak drought conditions. Rainfall was below average during each of the preceding 12 months. The potentiometric surface of the Upper Floridan aquifer recovered slightly from the drought conditions in September 2007 because the rainfall in September 2007 was 29 percent above average. The potentiometric surface changed little during 2008 in response to sporadic rainfall, with some months well above average and others well below average.

The discharge potential of the Upper Floridan aquifer generally increased during the study period (figs. 24 and 25). Discharge and recharge potential are quantified by the head difference between the surficial aquifer and the Upper Floridan aquifer, with positive values for upward flow, and negative values for downward flow, respectively. The increase in discharge potential was caused by the slow recovery of the potentiometric surface of the Upper Floridan aquifer as rainfall returned to near normal levels in water year 2008 following the exceptionally dry 2006 and 2007 water years. As recharge increased in the uplands, so too did discharge in the lowlands. Head differences between the surficial and Upper Floridan aquifers ranged from $-1.47 \mathrm{ft}$ in the Big Jones Creek well nest (GW5-GW6) in July 2008 to $+3.04 \mathrm{ft}$ at ROMP well nest LP-6 (GW37-GW38) in August 2008 (fig. 11 and table 3).

The central position of the recharge and discharge areas was consistent throughout the study period, with only the periphery of these areas expanding and contracting depending on the hydrologic conditions. The interpolated discharge areas generally follow a southeast-northwest trend similar to the outline of Lake Panasoffkee and of the Tsala Apopka Lake system to the west (figs. 24 and 25). Discharge potential was greatest along the eastern and southeastern margins of the lake, and is consistent with the presence of an artesian well (figs. 24 and 25) that flowed throughout the study period along the southeastern periphery of the lake. A secondary discharge area was identified northwest of the lake near the town of Carlson. Recharge potential was greatest northeast and southeast of the study area in the Sumter and Lake Uplands (fig. 3) where land-surface elevations are more than $110 \mathrm{ft}$ above NGVD 29.

Continuous water levels were recorded in six of the seven well nests mentioned earlier. These data present a much more detailed view of temporal changes in head differences between the Upper Floridan and surficial aquifers and their responses to individual rainfall events than the twice annual water-level data collected for the potentiometricsurface maps. Although head differences fluctuated from 0 to $2 \mathrm{ft}$ in the ROMP LP-6 (GW37-GW38) and Wysong Dam well nests (GW14-GW15) (fig. 11 and table 3), discharge potential was consistent (positive head difference) from the Upper Floridan aquifer to the surficial aquifer throughout the study period (fig. 26A). The higher heads in the Upper Floridan aquifer at these two well nests compared to other well nests are likely affected by the presence of Hawthorn Group clays that create locally confined conditions. Water levels at the Wysong Dam well nest might be influenced by the nearby dam; the dam was not in operation from the beginning of data collection until about October 2007, and head differences were more variable starting in December 2007 (fig. 26A). The Upper Floridan aquifer head was higher than the surficial aquifer water level during the entire period the dam was not in operation during this study. The well nests at Little Jones Creek (GW7-GW8), Big Jones Creek (GW5-GW6), and to some degree ROMP LP-5 (GW31-GW32) (fig. 11 and table 3) generally had flatter head differences than those at ROMP LP-6 (GW37-GW38) and Wysong Dam (GW14-GW15), with oscillations between recharge and discharge conditions occurring at each well nest (figs. 26B and $C$ ). Head differences at Big Jones Creek well nest, and especially at Little Jones Creek well nest, had small fluctuations between October 2006 and the beginning of the 2007 wet season in August 2007. From August 2007 to the end of the study period, however, head differences 

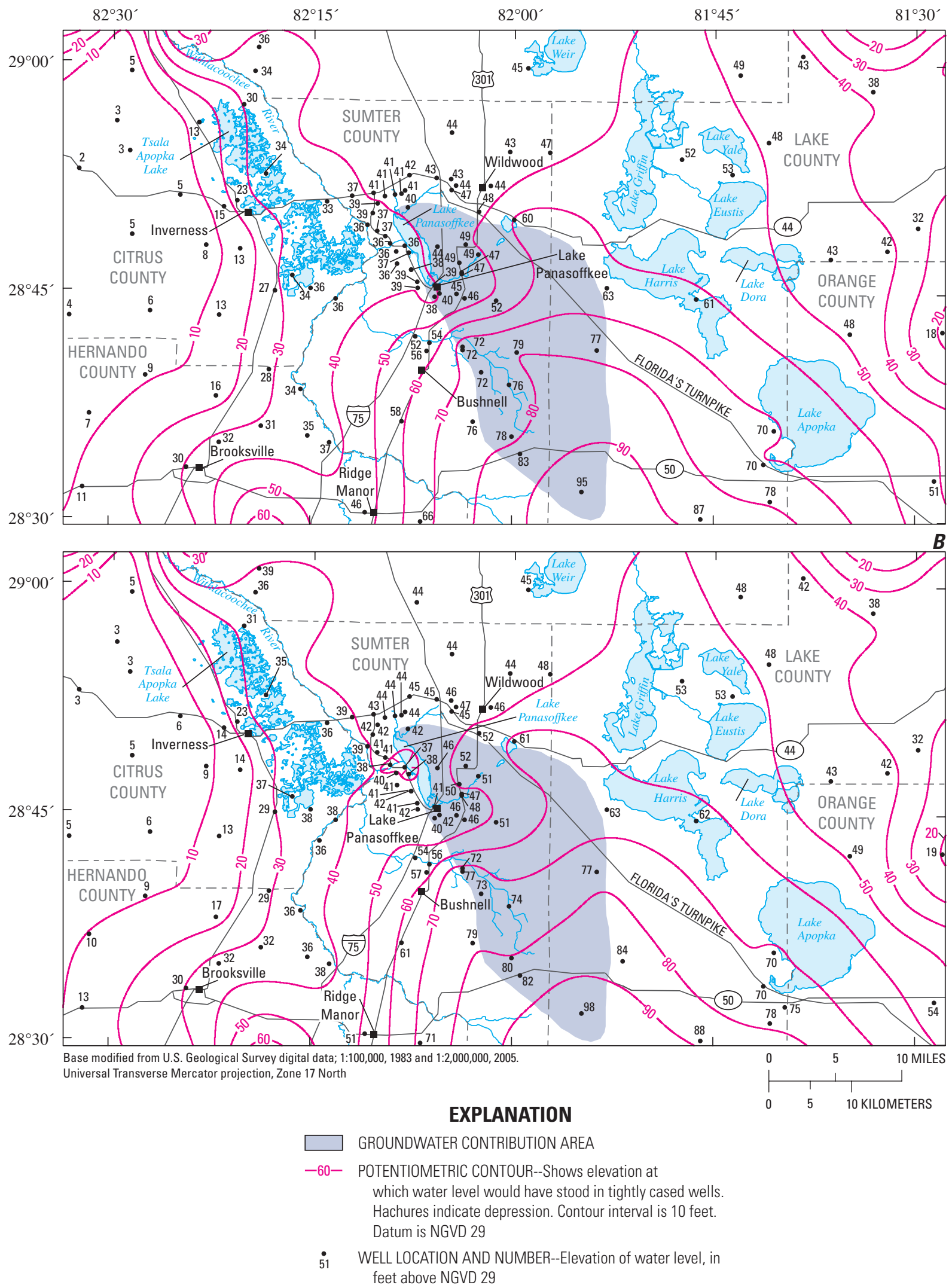

Figure 22. Generalized potentiometric-surface map of the Upper Floridan aquifer in the Lake Panasoffkee study area during $A$, May 2007 and $B$, September 2007. Modified from Ortiz (2008a and b). 

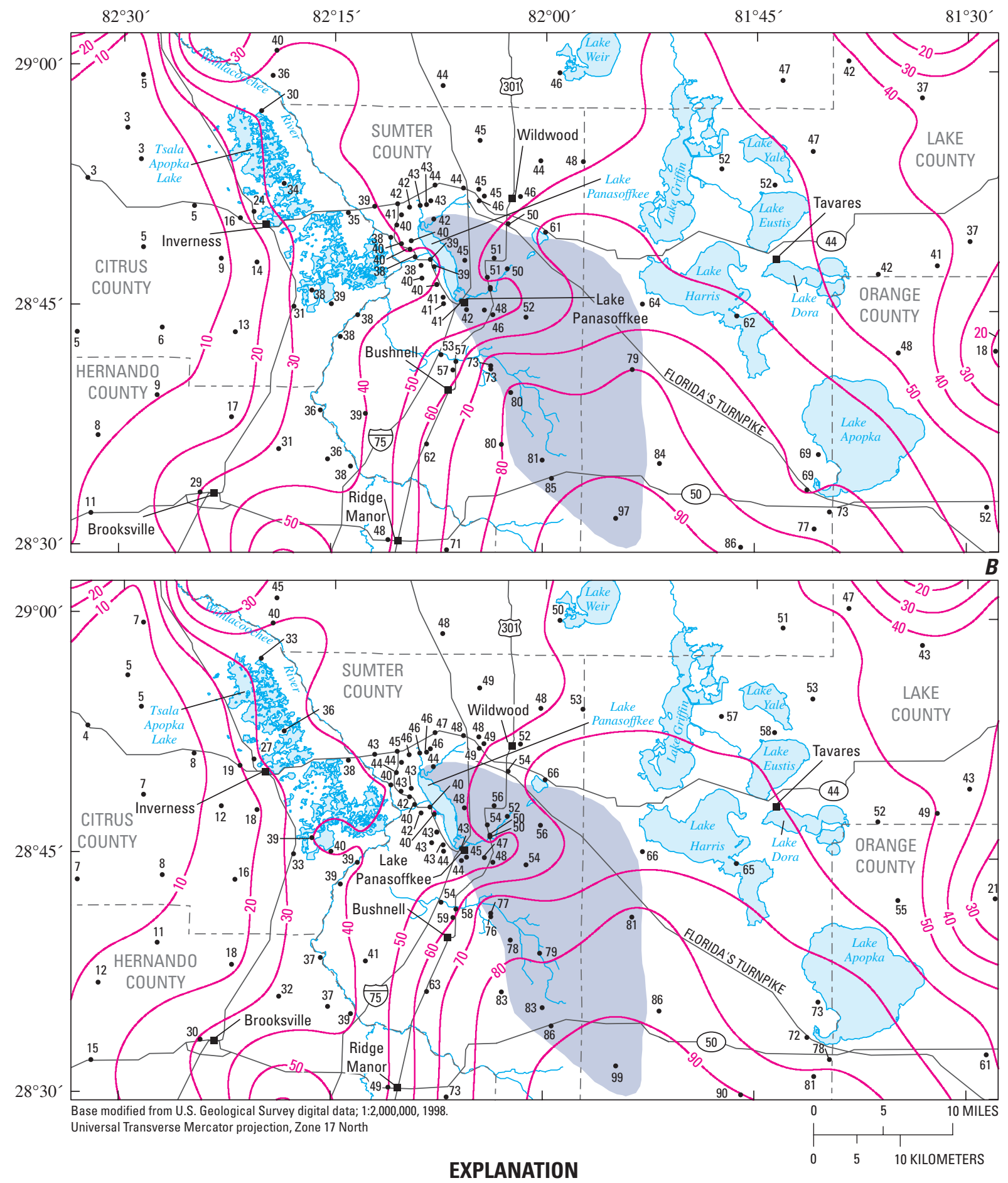

GROUNDWATER CONTRIBUTION AREA

-50- POTENTIOMETRIC CONTOUR--Shows elevation at

which water level would have stood in tightly cased wells. Hachures indicate depression. Contour interval is 10 feet. Datum is NGVD 29

- WO WELL LOCATION AND NUMBER--Elevation of water level, in feet above NGVD 29

Figure 23. Generalized potentiometric-surface map of the Upper Floridan aquifer in the Lake Panasoffkee study area during $A$, May 2008 and $B$, September 2008. Modified from Ortiz (2008c and 2009). 

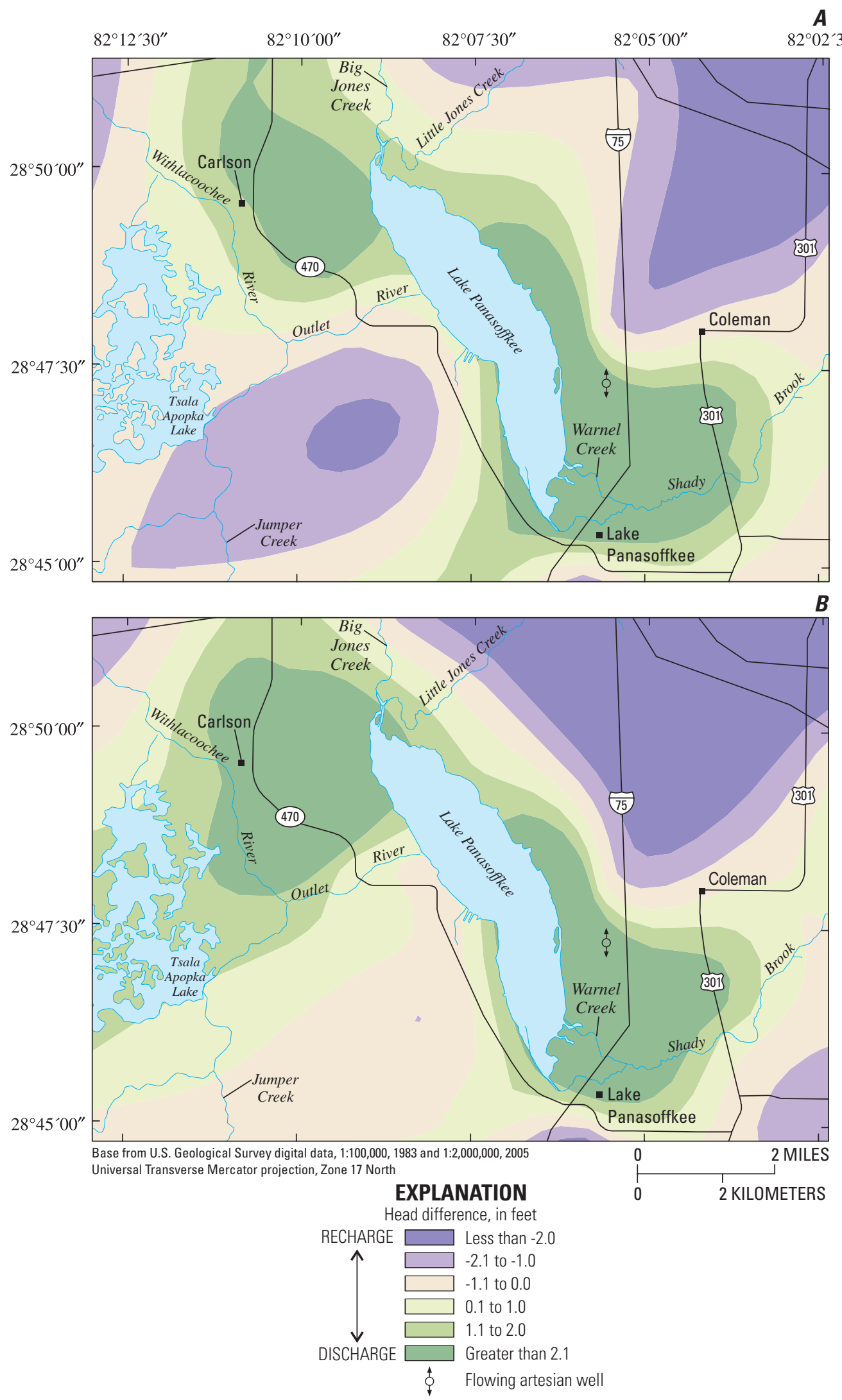

Figure 24. Areas of recharge and discharge potential between the surficial aquifer and the Upper Floridan aquifer in the Lake Panasoffkee study area for A, May 2007 and B, September 2007. 

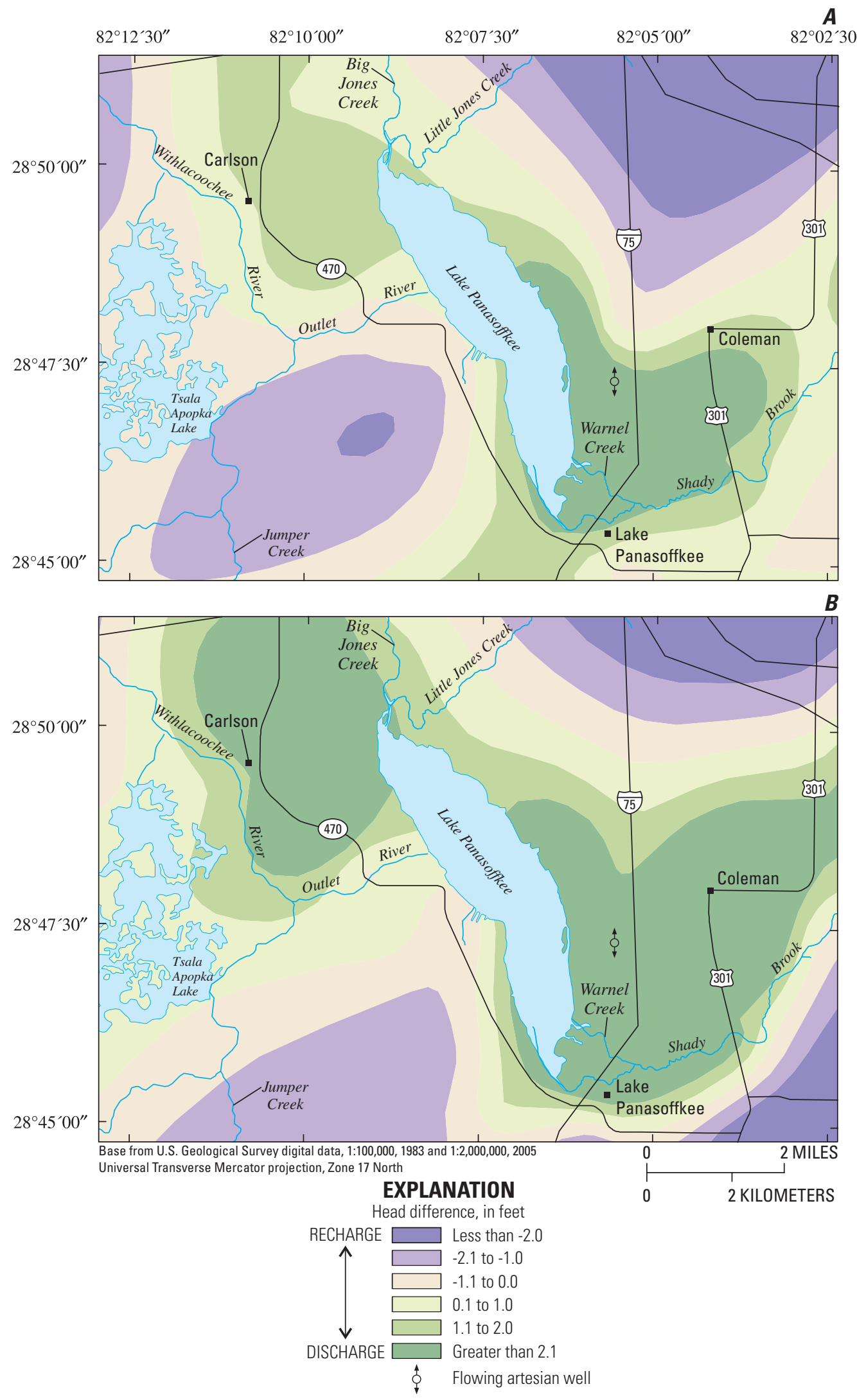

Figure 25. Areas of recharge and discharge potential between the surficial aquifer and the Upper Floridan aquifer in the Lake Panasoffkee study area for A, May 2008 and $B$, September 2008. 

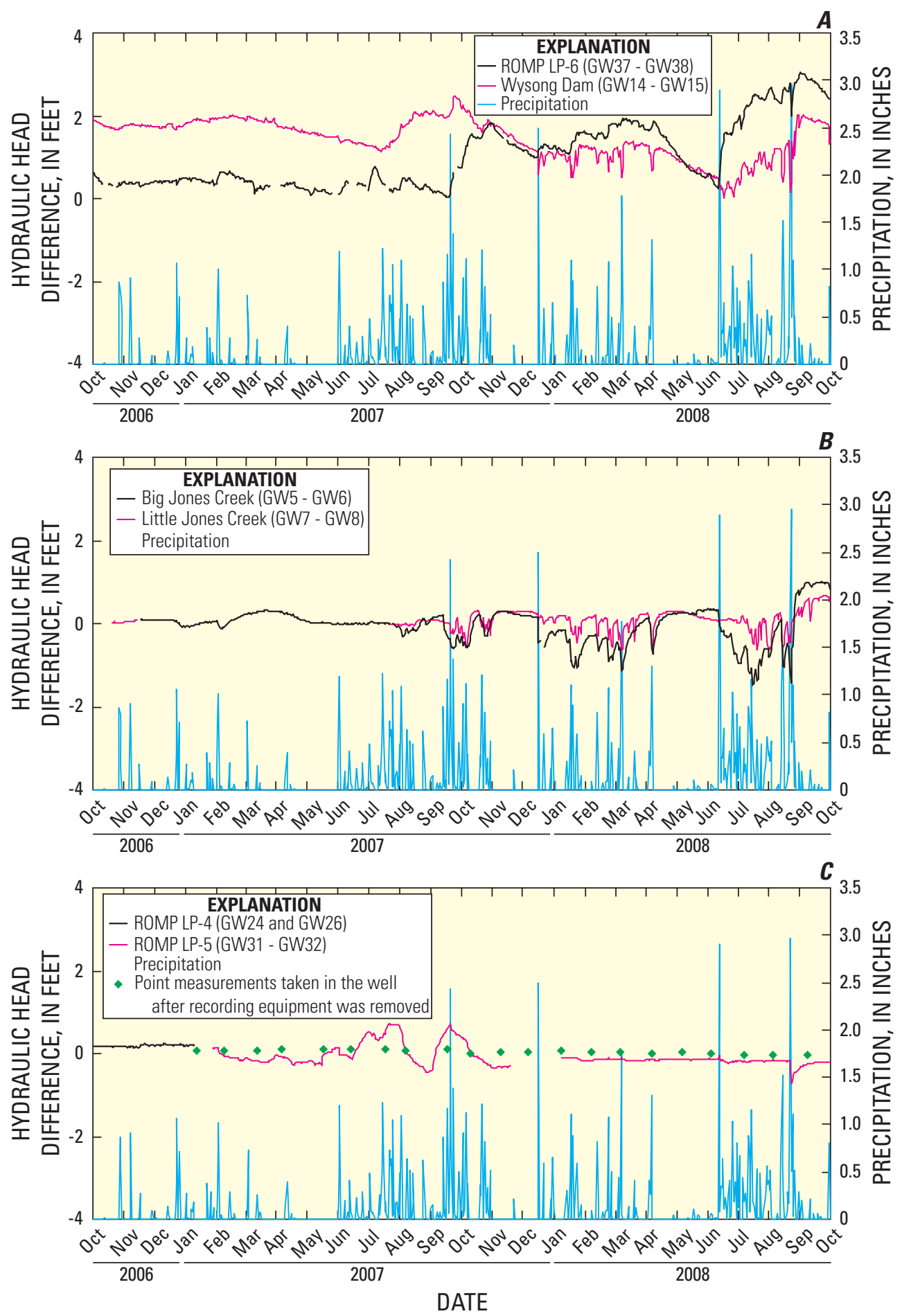

Figure 26. Difference in hydraulic head between the surficial aquifer and Upper Floridan aquifer near Lake Panasoffkee A, LP-6 and Wysong Dam well nests; $B$, Big Jones Creek and Little Jones Creek well nests; and C, LP-4 and LP-5 well nests, October 2006 through September 2008. Positive hydraulic head values indicate potential discharge from the Upper Floridan aquifer, whereas negative values indicate recharge potential. Figure 11 and table 3 contain well location and well specification information. 
at these well nests oscillated rapidly between recharge and discharge conditions, even during the dry season. Headdifference oscillations at ROMP LP-5 were small from the beginning of data collection in January 2007 until about May 2007, when large, low-frequency oscillations began (fig. 26C). These large oscillations ended abruptly around November 2007, and differences at ROMP LP-5 remained nearly constant with (negative) recharge potential from the surficial aquifer to the Upper Floridan aquifer for most of the remainder of the study period. The Hawthorn Group clays are absent at ROMP LP-5. This absence results in a better hydraulic connection between the Upper Floridan aquifer and surficial aquifer at ROMP LP-5 than at the Big Jones Creek and Little Jones Creek well sites. The lack of confinement at this site explains the nearly constant head differences recorded at ROMP LP-5 from November 2007 through the end of the study.

During the third week of August 2008, 4 days of heavy rainfall (an average of almost 3 in. in the Lake Panasoffkee basin) resulted in a sharp recharge peak at ROMP LP-5 (GW31-GW32), and especially at Little Jones Creek (GW7GW8) and Big Jones Creek (GW5-GW6) (figs. 11, 26B and $C$, table 3). During the week following this rainfall event, the head differences at the Little Jones Creek and Big Jones Creek well nests recovered quickly to a state of discharge potential from the Upper Floridan aquifer to the surficial aquifer. The head differences at ROMP LP-5, however, followed a more gradual asymptotic recovery, returning after about 7 weeks to a state of recharge potential from the surficial aquifer to the Upper Floridan aquifer, similar to conditions that existed before the rain event. The difference in response between the three well nests can be attributed to the thickness of the unsaturated zone and the thickness of the surficial aquifer at each site. The surficial aquifer deposits are $5 \mathrm{ft}$ thick or less at both the Big Jones Creek and Little Jones Creek well sites, whereas the surficial aquifer is $56 \mathrm{ft}$ thick at site ROMP LP-5. The greater water-storage capacity of the surficial aquifer at site ROMP LP-5 compared to the other sites results in slower recovery at this site after major rain events because the unsaturated zone is thicker.

The head difference between the Upper Floridan and surficial aquifers at ROMP LP-4 (GW24 and GW26) on the west side of the lake is slightly positive and shows little variation over time, indicating steady, upward groundwater discharge potential (figs. 11 and 26C, table 3). Continuous data were collected until January 2007 when the data logger was removed from the surficial aquifer well; only monthly periodic measurements are available thereafter. The periodic ROMP LP-4 measurements corroborate the trend of a small potential for upward groundwater discharge. Similar to ROMP LP-5 (GW31-GW32), the Hawthorn Group is absent or very thin at ROMP LP-4, indicating potential hydraulic connection between the Upper Floridan and surficial aquifers. Whereas the period of low frequency oscillation in head differences at ROMP LP-5 occurs after the continuous data collection at ROMP LP-4 ended in January 2007, it is still evident in figure $26 C$ that head differences at ROMP LP-4 and ROMP LP-5 remained similar to each other and, therefore, the surficial and Upper Floridan aquifers respond similarly to precipitation at these sites.

The dry-season measurement in 2007 indicated an upward head difference in the northwest (GW18) and westcentral (GW22) lake piezometer sites, and a downward head difference at the southern site (GW30) (fig. 11 and table 3). The September 2007 wet season yielded the opposite condition, with downward (negative) head differences measured from the surficial aquifer to the Upper Floridan aquifer at the northwestern and west-central sites, whereas the southern site experienced upward (positive) head differences from the Upper Floridan aquifer to the surficial aquifer. All of the measurements made in 2008, during both the wet and dry seasons, indicated upward head differences from the Upper Floridan aquifer to the surficial aquifer. Both the northwest and west-central piezometer sites tended to mirror the relation between the Upper Floridan aquifer and surficial aquifer at ROMP LP-4 (GW24 and GW26, fig. 11 and table 3). When water levels in the surficial aquifer were higher than Lake Panasoffkee levels at the lakeshore piezometer sites, the head in the Upper Floridan aquifer was also higher than the surficial aquifer at nested well site ROMP LP-4, indicating upward heads in both the Upper Floridan and surficial aquifers. Head differences at the southern piezometer site were usually in the same direction as at ROMP LP-6 (GW37GW38, fig. 11 and table 3). During the wet season in 2007, however, Lake Panasoffkee water levels were higher than the water levels in the surficial aquifer, reflecting recharging conditions. At ROMP LP-6, Upper Floridan aquifer heads also were higher than water levels in the surficial aquifer, reflecting upward discharge conditions.

\section{Geophysics}

Direct measurement of groundwater inflow rates using electromagnetic seepage meters would have been useful in corroborating the groundwater inflow data calculated from the water budget. For a period of 1 week in February 2007, an attempt was made to directly measure groundwater inflow rates in Lake Panasoffkee. Unfortunately, very soft organic sediment that constitutes much of the lakebed prevented the seepage meters from properly sealing. Because the seals were not complete, groundwater discharge probably by-passed the electromagnetic flow meter and was lost to the lake, rendering the estimates inconclusive.

Seismic-reflection surveys can be a useful tool for qualifying subsurface hydrogeologic features beneath a lake (Kindinger, 2002). Although a seismic reflection survey does not quantify the volume of water exchanged between groundwater and surface water, it can help identify features, such as sinkholes, springs, and faults, where exchange may occur (Tihansky and others, 1996). Seismic reflection surveys also may determine the presence or absence of confining units beneath a lake (Tihansky and others, 1996). A continuous 
seismic-reflection profiling survey of Lake Panasoffkee was first attempted in May 2006, but water levels in Lake Panasoffkee were extremely low at that time and floating aquatic vegetation covered much of the lake surface.

The combined low water levels and thick vegetation made boat navigation difficult. Attempts were made to survey the lake using both the high-frequency CHIRP and the low-frequency electromagnetic seismic Boomer. The high-frequency signal produced by the CHIRP was attenuated by aquatic vegetation before penetrating the lakebed. It is believed that gas bubbles trapped by growing vegetation and within the organic debris at the lake bottom disrupted the wave form of the acoustic pulse, returning spurious signals to the hydrophones. The higher energy propagated by the Boomer system was capable of penetrating the vegetation, but signal loss was still evident. After running various unsuccessful survey lines, the effort was abandoned with little usable data collected.

A second seismic reflection survey was attempted at Lake Panasoffkee in May 2008 using the same equipment. Lake conditions during this survey were much improved, with parts of the lake newly opened by dredging as part of the lake restoration effort. Water levels also were much higher than in May 2006, resulting in a lake surface free of floating aquatic vegetation. The CHIRP was used for the first profile attempt, with much the same result as in 2006. Even with the lake surface clear of vegetation, the CHIRP was unable to efficiently penetrate the vegetation and trapped gas bubbles covering most of the lake bottom. The Boomer was used for the remainder of the survey.

Although several potential subsurface features were detected beneath Lake Panasoffkee while running the seismic survey lines, none of the features could be reproduced when they were investigated a second time. Because the features could not be reproduced there is doubt that they were real. A persistent but faint subsurface feature was detected from 60 to $100 \mathrm{ft}$ beneath the lakebed under much of the lake, but the noise in the data made it impossible to determine if the feature was real or perhaps caused by interference between the boat and the seismic equipment. Although the depth at which the potential geologic feature was detected roughly corresponds with the top of the Avon Park Formation in some of the wells adjacent to Lake Panasoffkee, the poor quality of the data prevented any definite conclusions from being drawn. The complete Lake Panasoffkee seismic-reflection survey is documented in Harrison and others (2009).

\section{Surface-Water Hydrology}

The surface-drainage basin of Lake Panasoffkee encompasses roughly $360 \mathrm{mi}^{2}$ in Sumter, Marion, and Lake Counties (fig. 2). The sparseness of surface-water features north of S.R. 44, in combination with the low topographic relief of the study area, suggests that the effective surface drainage area of the lake is much smaller. Lake Panasoffkee has two main tributaries, Little Jones Creek and Shady Brook, and one outlet, the Outlet River (fig. 10). Warnel Creek, a distributary of Shady Brook (fig. 10), also contributes water to Lake Panasoffkee, although the net effect on the lake water budget from this tributary during the study was small. Big Jones Creek (fig. 10), a fourth tributary of Lake Panasoffkee, contributed almost no water to the lake during this study because it only began to flow during the last month of data collection (September 2008). At the Big Jones Creek gaging station (SW5, fig. 10), water was pooled in the channel over much of the study period and flow over the control was rarely observed. An area of diffuse, poorly channelized flow along the eastern edge of the lake may contribute substantial amounts of surface water to the lake during periods of heavy rainfall, but estimations made of surface-water flow from this area during this study showed little overall effect on the lake water budget. The entire Lake Panasoffkee watershed is a major contributor of surface-water inflow to the Withlacoochee River, through the Outlet River (Trommer and others, 2009).

\section{Streamflow}

The major contributors of surface water to Lake Panasoffkee during the study period were Little Jones Creek and Shady Brook (fig. 10 and table 6). Warnel Creek also contributed surface-water flow, but only from December 2007 through September 2008. The average monthly discharge from Little Jones Creek to Lake Panasoffkee between April 2006 and September 2008 ranged from $6.56 \mathrm{ft}^{3} / \mathrm{s}$ in June 2007 to $75.8 \mathrm{ft}^{3} / \mathrm{s}$ in August 2008 (U.S. Geological Survey, 2009). The total discharge from Little Jones Creek to Lake Panasoffkee during this period was 2.36 billion $\mathrm{ft}^{3}$. The water year 2007 total was 523 million $\mathrm{ft}^{3}$ and the water year 2008 total was 1.22 billion $\mathrm{ft}^{3}$. The average monthly discharge from Shady Brook to Lake Panasoffkee between April 2006 and September 2008 ranged from $8.28 \mathrm{ft}^{3} / \mathrm{s}$ in June 2007 to $59.6 \mathrm{ft}^{3} / \mathrm{s}$ in September 2008 (U.S. Geological Survey, 2009). The total discharge from Shady Brook to Lake Panasoffkee during this period was 1.65 billion $\mathrm{ft}^{3}$. Shady Brook contributed 357 million $\mathrm{ft}^{3}$ of total flow to Lake Panasoffkee in water year 2007 and 897 million $\mathrm{ft}^{3}$ of total flow in water year 2008 . Average monthly discharge from Warnel Creek (when it was flowing) ranged from $0.10 \mathrm{ft}^{3} / \mathrm{s}$ in December 2007 to $12.4 \mathrm{ft}^{3} / \mathrm{s}$ in August 2008. Warnel Creek did not flow in water year 2007 and it contributed 113 million $\mathrm{ft}^{3}$ of total flow to Lake Panasoffkee in water year 2008. The combined discharge from Little Jones Creek, Shady Brook, and Warnel Creek was 51 and 49 percent of the total inflow to Lake Panasoffkee during water years 2007 and 2008, respectively.

The average monthly discharge from Lake Panasoffkee to the Outlet River (fig. 10) between April 2006 and September 2008 ranged from $12.6 \mathrm{ft}^{3} / \mathrm{s}$ in June 2007 to $225 \mathrm{ft}^{3} / \mathrm{s}$ in August 2008 (U.S. Geological Survey, 2009; table 6). The total discharge from Lake Panasoffkee to the Outlet River during the 29-month period was 5.50 billion $\mathrm{ft}^{3}$. Typically, the 


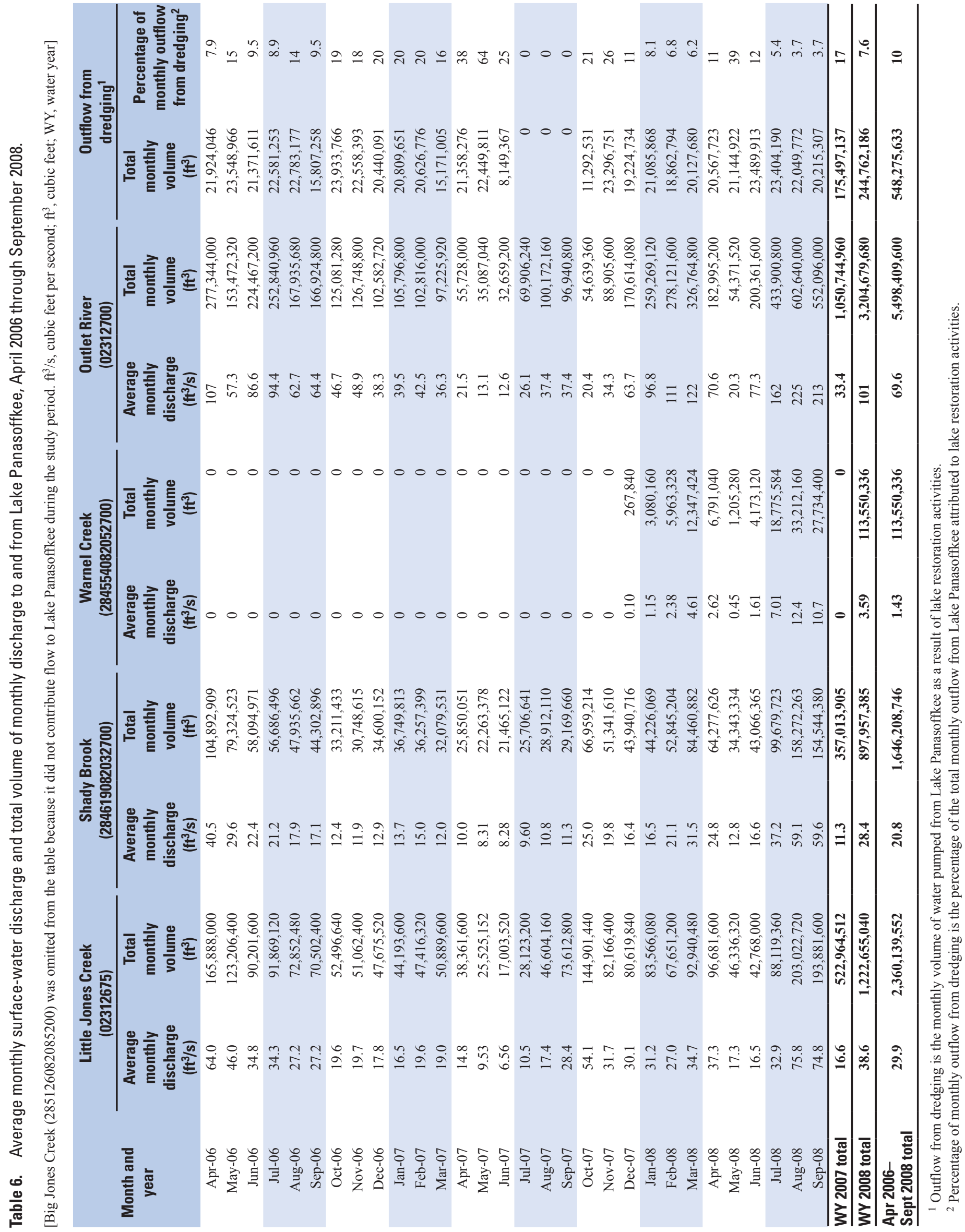


Outlet River accounts for almost all of the surface-water discharge from the lake, but during the study period, water was being pumped from the lake as part of the lake-restoration activities. The pumpage lowered the lake level, and therefore, decreased the volume of outflow from Lake Panasoffkee to the Outlet River, so discharge may appear low for the study period compared to other periods with similar climatic conditions. Monthly outflow from dredging from April 2006 through September 2008 totaled 548 million $\mathrm{ft}^{3}$ and average monthly pumpage ranged from 8.15 million $\mathrm{ft}^{3}$ in June 2007 to 23.9 million $\mathrm{ft}^{3}$ in October 2006 (table 6). Dredging accounted for a minimum of 3.7 percent of the total monthly surface-water outflow, in both August and September 2007, and a maximum of 64 percent of the total outflow in May 2007. No dredging occurred in July, August, and September 2007 because the drought resulted in unusually low lake levels. On average, dredging accounted for 10 percent of the total surface-water outflow from Lake Panasoffkee from April 2006 through September 2008.

\section{Spring Inflows}

Spring discharge measurements were made during four seepage runs to determine the groundwater contributions of each spring to Lake Panasoffkee (table 7). During the December 2007, July 2008, and September 2008 seepage runs, about 67 to 76 percent of the discharge in Little Jones Creek and Shady Brook (fig. 10) was derived from springs. During the March 2008 seepage run, 82 and 91 percent of the discharge in Little Jones Creek and Shady Brook, respectively, was contributed by spring flow. The flow in excess of these percentages probably derives from diffuse groundwater inflow. A small percentage may be attributed to overland flow, but overland flow was assumed to be minimal because the seepage runs were completed under baseflow conditions. The seepage runs are detailed below in the section titled "streamflow gains and losses."

During the seepage runs, the single largest spring contributor to Lake Panasoffkee was Henry Green Spring (SP20, fig. 5 and table 1), which forms the head of Little Jones Creek near the intersection of S.R. 44 and I-75. Measured discharge at Henry Green Spring ranged from $7.98 \mathrm{ft}^{3} / \mathrm{s}$ in April 2007 to $23.6 \mathrm{ft}^{3} / \mathrm{s}$ in September 2008; the April 2007 Henry Green Spring discharge measurement was not part of a seepage run (U.S. Geological Survey, 2009). The second and third largest contributors were Fenney Spring (SP18) and Wayne Lee Spring (SP19), respectively (fig. 5 and table 1). Measured discharge at Fenney Spring ranged from $3.07 \mathrm{ft}^{3} / \mathrm{s}$ in December 2007 to $28.4 \mathrm{ft}^{3} / \mathrm{s}$ in September of 2008, and discharge at Wayne Lee Spring ranged from $6.55 \mathrm{ft}^{3} / \mathrm{s}$ in July 2008 to $24.2 \mathrm{ft}^{3} / \mathrm{s}$ in September 2008 (table 7).

A maximum discharge of $80 \mathrm{ft}^{3} / \mathrm{s}$ at Fenney Spring (SP18) was based on the period-of-record maximum gage height of $54.86 \mathrm{ft}$ above NGVD 29 on August 28, 2008 (fig. 5 and table 1) (U.S. Geological Survey, 2009). Discharge at
Fenney Spring was estimated using a 2nd-order polynomial curve that was fit to a plot of spring discharge in relation to water-level measurements made in a surficial aquifer monitoring well (GW43) adjacent to the spring pool $\left(\mathrm{R}^{2}=0.98\right)$ :

$$
y=16.928 x^{2}-1785.4 x+47,078
$$

where

$y$ is spring discharge and

$x$ is the water level in the monitoring well, in feet above NGVD 29 (fig. 5 and table 1).

Surficial aquifer water levels were used to develop the regression equation because of a lack of gage-height measurements defining the upper end of the gage height-discharge relation. Because surficial aquifer water levels were used to estimate maximum discharge, it was necessary to compare these water levels to gage height in order to determine the suitability of using water levels as a proxy for gage height. Differences between water levels and gage heights were less than 0.20 percent or $0.10 \mathrm{ft}$, with a maximum expected error of $0.1 \mathrm{ft}^{3} / \mathrm{s}$. No-flow conditions were observed at Fenney Spring during a site inspection on June 6, 2007, at a gage height of $51.48 \mathrm{ft}$ (U.S. Geological Survey, 2009). Based on the hydrograph for this site for the study period, no-flow conditions probably occurred from April through July 2007.

\section{Ungaged Flow}

The land along the eastern margin of Lake Panasoffkee is generally flat and is composed of mucky soils interspersed with small, sandy islands. Overland flow in this region is typified by poorly channelized sheetflow that is constrained by culverts that divert flow underneath a dirt access road. The road runs north and south, parallel to the eastern shore of Lake Panasoffkee, and acts as a berm in low-lying areas. All of the overland flow into Lake Panasoffkee from east of this road is routed through the culverts before emptying back into the swamp west of the dirt road. Discharge was observed at some of these culverts early in the reconnaissance phase of the study, but was not measured at that time. Water was only flowing through a single culvert during the first three seepage runs, with flows of $1.22,3.14$, and $0.53 \mathrm{ft}^{3} / \mathrm{s}$ measured in December 2007, March 2008, and July 2008, respectively. In September 2008, water was found to be flowing through two culverts with a combined flow of $12.6 \mathrm{ft}^{3} / \mathrm{s}$ (table 7).

\section{Lake Level}

The SWFWMD has drafted a new set of Minimum and Guidance Levels for Lake Panasoffkee that will supersede the current set of Guidance Levels adopted in 1982 (Southwest Florida Water Management District, 2006). The SWFWMD proposes three guidance levels and two minimum levels-all of which are based on needs for recreational use, maintenance of aquatic habitat, and lakeshore development. Of particular 
Table 7. Summary of measured discharge at spring and surface-water stations in the Lake Panasoffkee study area during four seepage runs from December 2007 through September 2008.

[ $\mathrm{ft}^{3} / \mathrm{s}$, cubic feet per second; n/a, not applicable; E, estimated value]

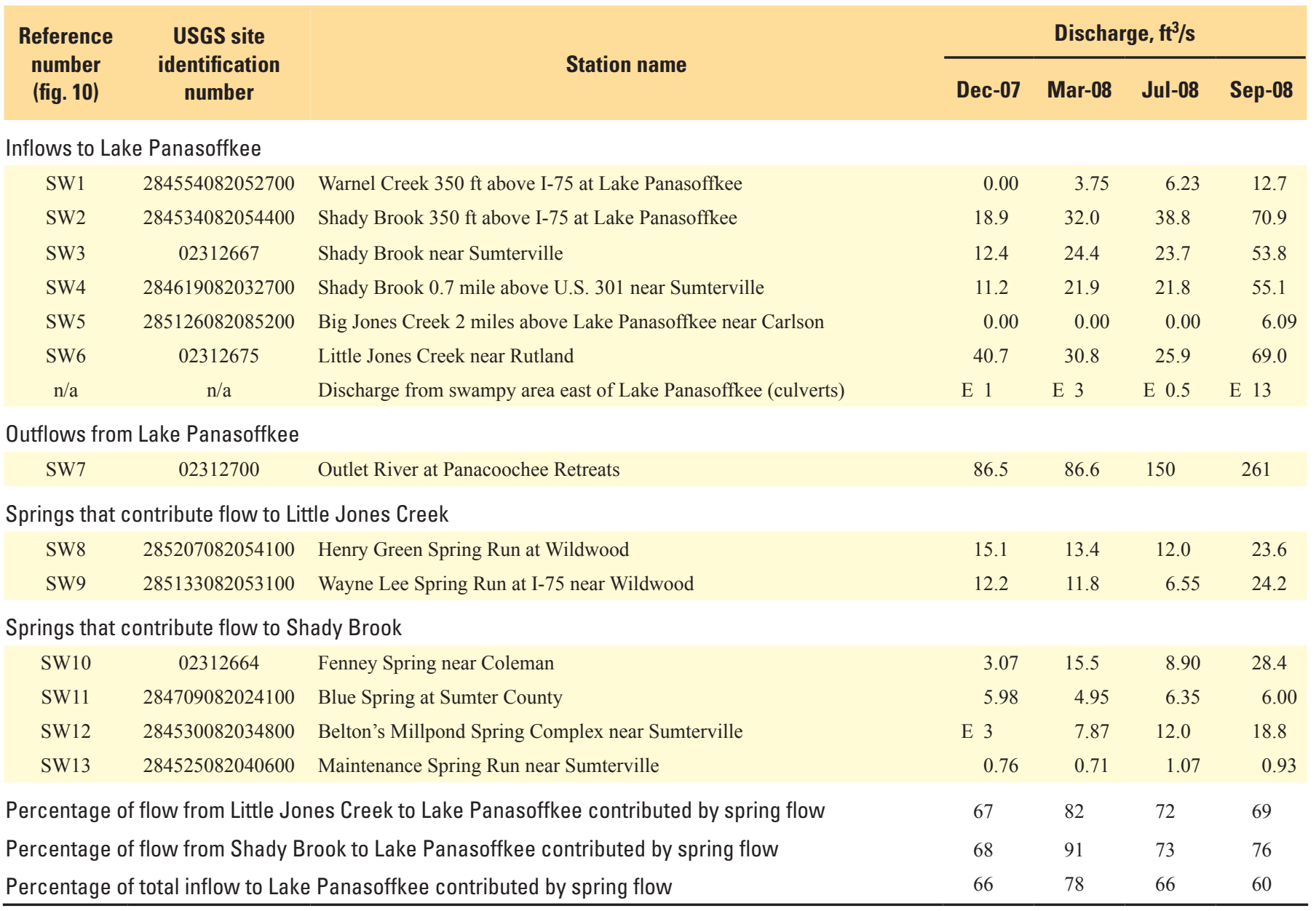

interest to this study are the new Low Guidance Level $(38.9 \mathrm{ft}$ above NGVD 29), Minimum Lake Level (39.4 ft above NGVD 29), and High Minimum Lake Level (40.8 ft above NGVD 29).

The Low Guidance Level (LGL) is defined as "the elevation that a lake's water levels are expected to equal or exceed 90 percent of the time (P90) on a long-term basis" (Southwest Florida Water Management District, 2006). This corresponds roughly to the existing "Extreme Low Level" (38.5 ft above NGVD 29) under the current set of Guidance Levels. The P90 of the lake from April 2006 to September 2008 was $37.2 \mathrm{ft}$ above NGVD 29, and the proposed LGL was exceeded only 40 percent of the time (fig. 27). The Minimum Lake Level (MLL) of $39.4 \mathrm{ft}$ above NGVD 29 is the P50 level, the water level expected to be equaled or exceeded 50 percent of the time on a long-term basis. The MLL was exceeded only 30 percent of the time between April 2006 and September 2008. The measured P50 of the lake during the study period was only $38.2 \mathrm{ft}$ above NGVD 29. The High Minimum Lake
Level (HMLL) was not reached during the study period; the maximum stage recorded during the study period was $40.42 \mathrm{ft}$ above NGVD 29.

Lake stage fluctuated $3.44 \mathrm{ft}$ between October 2006 and September 2008, with a minimum stage of $36.98 \mathrm{ft}$ above NGVD 29 and a maximum stage of $40.42 \mathrm{ft}$ above NGVD 29 (fig. 27). Lake levels fell consistently from $37.66 \mathrm{ft}$ above NGVD 29 on October 1, 2006, to $36.98 \mathrm{ft}$ above NGVD 29 on June 30, 2007. Around October 1, 2007, lake levels began to rise quickly without a commensurate increase in discharge at Outlet River. This occurred because water in the Withlacoochee River was impounded by the Wysong Dam (fig. 1), which caused backwater effects all the way up Outlet River into Lake Panasoffkee. In all, lake levels rose from $37.86 \mathrm{ft}$ above NGVD 29 on October 1, 2007, to a maximum of $39.23 \mathrm{ft}$ above NGVD 29 on October 31, 2007. This rise in lake stage equates to an increase in storage of roughly 200 million $\mathrm{ft}^{3}$ (1.5 billion gallons). 


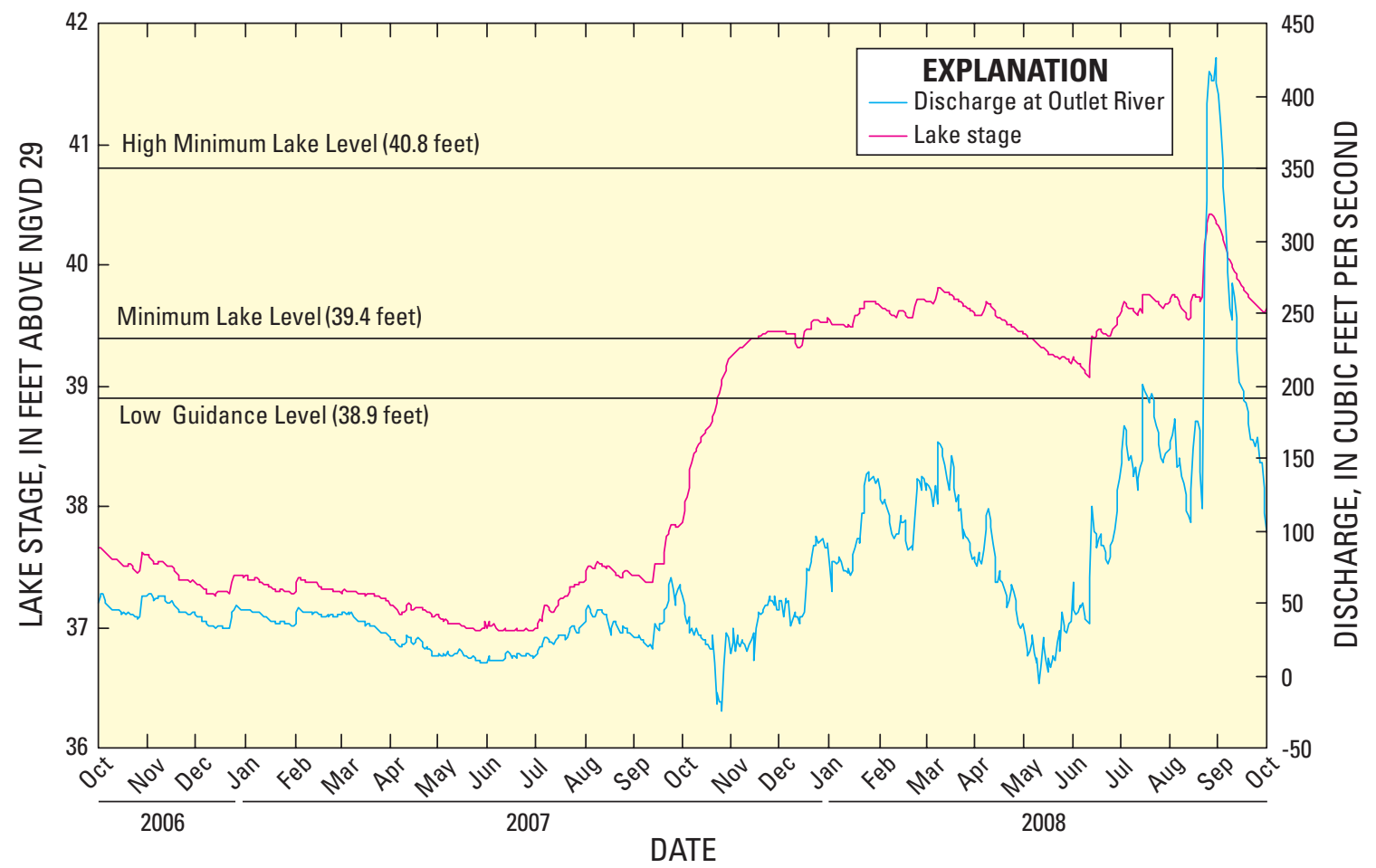

Figure 27. Lake stage and discharge at Pana Vista Lodge (SWFWMD Gage 23142 Pana Vista Outlet River), October 2006 through September 2008. SWFWMD is Southwest Florida Water Management District.

\section{Streamflow Gains and Losses}

Although all seepage runs were conducted during baseflow conditions when hydrologic conditions were static, the later seepage runs reflected higher water conditions compared to the earlier ones, which were affected by the antecedent drought. The highest documented flows during the seepage runs were in September 2008, when Outlet River discharge measured $261 \mathrm{ft}^{3} / \mathrm{s}$. The lowest flows during the seepage runs were measured in December 2007 when Outlet River discharge was $86.5 \mathrm{ft}^{3} / \mathrm{s}$. The relative contribution from each stream reach to total streamflow during the four seepage runs is shown in figure 28. The range of flows presented here is probably lower than it would be for a typical year because of an ongoing drought. The drought began in 2005 before data collection started for this study and continued until the end of data collection in September 2008.

Seepage run data indicate that the primary tributaries to Lake Panasoffkee, Little Jones Creek and Shady Brook, are both gaining streams. Henry Green Spring (SW8) and Wayne Lee Spring (SW9) are the primary sources of water to Little Jones Creek (fig. 10 and table 2). In all four seepage runs (fig. 28), Little Jones Creek also gained additional flow between the springs and the downstream gage. In September 2008, the combined discharge for Henry Green Spring (SW8) and Wayne Lee Spring (SW9) was $47.8 \mathrm{ft}^{3} / \mathrm{s}$. Less than $3 \mathrm{mi}$ downstream, the measured discharge was $69.0 \mathrm{ft}^{3} / \mathrm{s}$ at the Little Jones Creek stream gage (SW6). Thus, Little Jones Creek gained an additional $21.2 \mathrm{ft}^{3} / \mathrm{s}$ of flow along this reach, nearly the volume of flow provided by Wayne Lee Springs $\left(24.2 \mathrm{ft}^{3} / \mathrm{s}\right)$ and Henry Green Springs $\left(23.6 \mathrm{ft}^{3} / \mathrm{s}\right)($ table 7$)$. The additional flow is either from unidentified springs, or, more likely, from groundwater inflow into the creek channel. This conclusion was corroborated by comparing continuous water-level data collected at the Shady Brook and Outlet River surface-water stations (fig. 29) to nearby groundwater-level data. Water-level data indicate a continuous upward head difference from the groundwater system into the streams. Surface-water runoff also likely contributed small amounts of flow during this seepage run, because the swamp adjacent to Little Jones Creek contained shallow standing water.

The headwater for Shady Brook is Fenney Spring (SW10, fig. 10 and table 2). Blue Spring (SW11) forms a run that empties into Shady Brook about $0.75 \mathrm{mi}$ downstream from the headwater. The combined flow from these springs in September 2008 was $34.4 \mathrm{ft}^{3} / \mathrm{s}$. A little more than 1 mi downstream from Fenney Spring, the discharge of Shady Brook (SW4) was measured at $55.1 \mathrm{ft}^{3} / \mathrm{s}$, which corresponds to a gain of $20.7 \mathrm{ft}^{3} / \mathrm{s}$. Discharge at the streamflow gage at U.S. 301 (SW3) was $53.8 \mathrm{ft}^{3} / \mathrm{s}$, for a difference of $1.3 \mathrm{ft}^{3} / \mathrm{s}$ (table 7). The small difference is statistically insignificant and should be interpreted as neither a net loss nor gain. West of U.S. 301, the combined flow from Belton's Millpond Spring Complex (SW12) and 


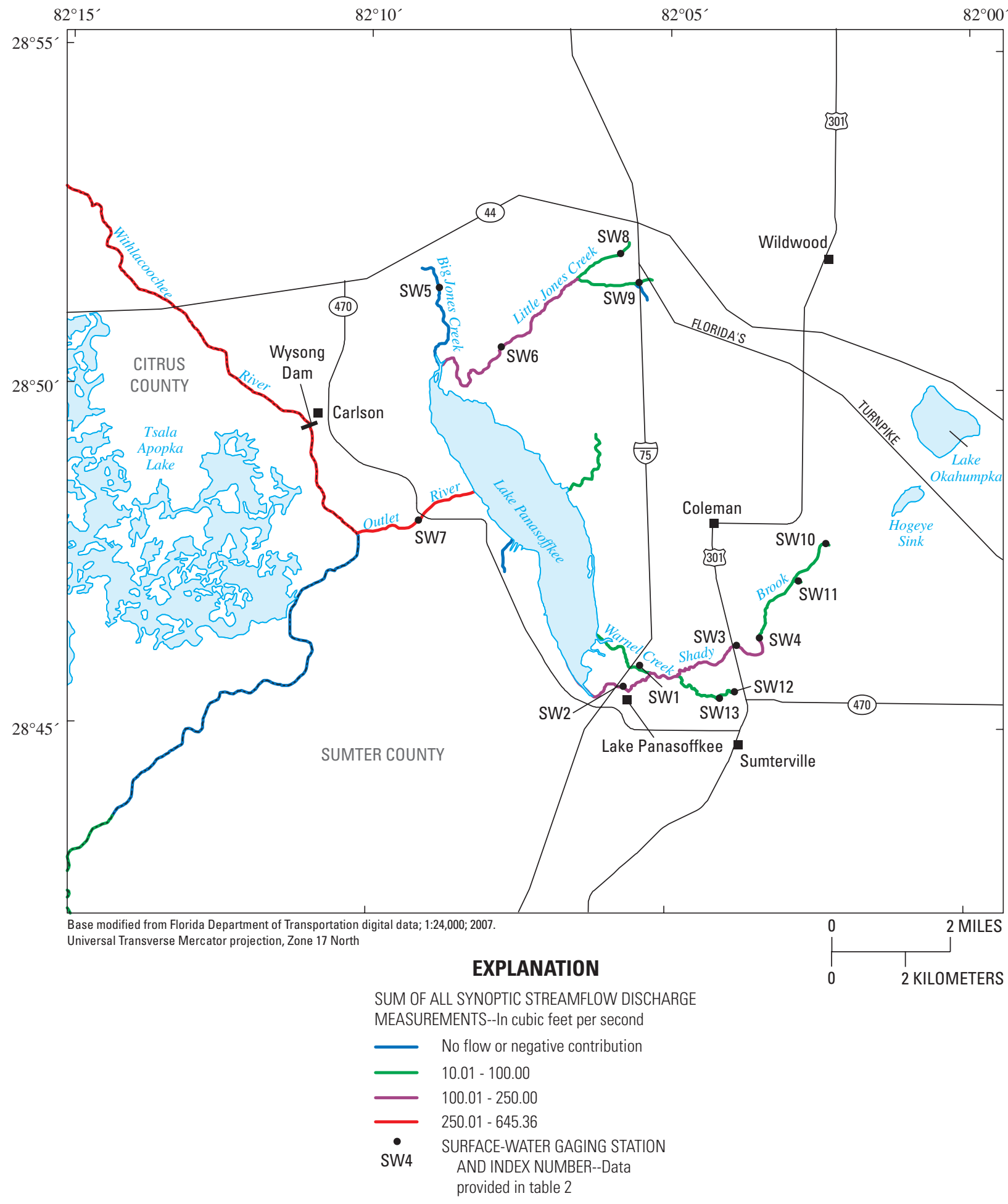

Figure 28. Relative flow contributions from each stream reach to total streamflow during four seepage runs, December 2007 through September 2008. 
Maintenance Spring (SW13) empties into Shady Brook. Flow from these springs in September 2008 was 18.8 and $0.9 \mathrm{ft}^{3} / \mathrm{s}$, respectively. Warnel Creek (SW1) diverges from Shady Brook upstream of the I-75 gage (SW2), and the flow at Warnel Creek at $\mathrm{I}-75$ in September 2008 was $12.7 \mathrm{ft}^{3} / \mathrm{s}$. With the addition of the spring flow from Belton's Millpond and Maintenance Spring, and the loss of flow to Warnel Creek, discharge at Shady Brook near I-75 was $70.9 \mathrm{ft}^{3} / \mathrm{s}$. The combined flow from Warnel Creek and Shady Brook, both near I-75, was $83.6 \mathrm{ft}^{3} / \mathrm{s}$ (table 7). This corresponds to a net gain of flow of $8.8 \mathrm{ft}^{3} / \mathrm{s}$ over what can be explained by the addition of spring flow from Belton's Millpond Spring Complex and Maintenance Spring. The increase in discharge is most likely groundwater inflow to Shady Brook.

\section{Water Budget}

Lake Panasoffkee interacts with the atmosphere, the subsurface, and other surface-water features. The lake gains water from rainfall, streamflow, spring flow, and groundwater seepage, and loses water by evaporation, surface outflow, and groundwater seepage (Healy and others, 2007; fig. 30). Under wet conditions, the lake also gains flow from overland runoff, a difficult component to compensate for in the water budget because there is no method available to accurately measure the volume of this input. The drought precluded this process from being a concern during the study period. The balance between water inputs and outputs to Lake Panasoffkee
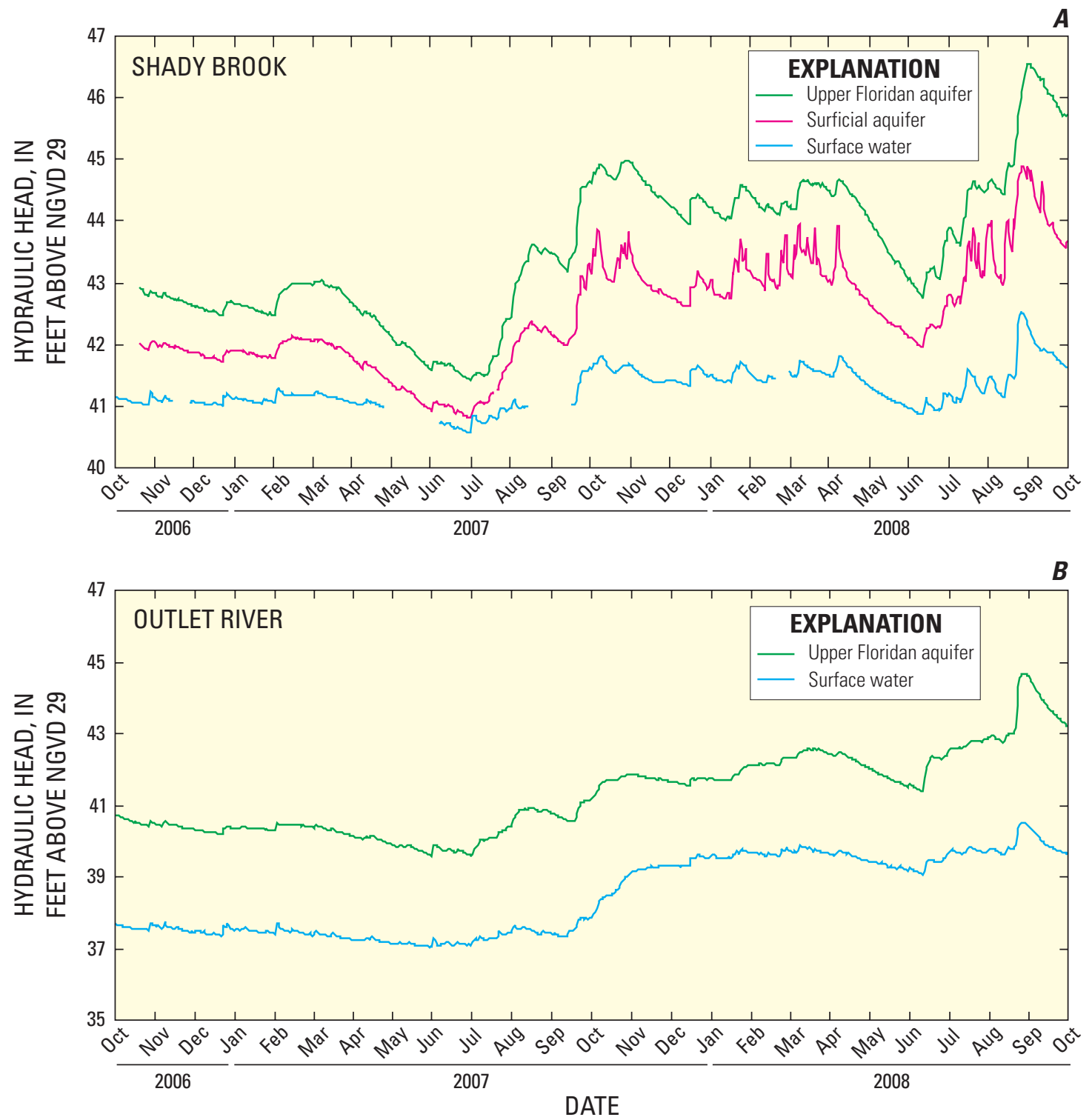

Figure 29. Hydraulic head data for $A$, Shady Brook and $B$, Outlet River, October 2006 through September 2008. 
results in changes in lake water level, except when inflows equal outflows. Lake water levels rise when inflows exceed outflows, and they fall when outflows exceed inflows.

A monthly water budget was developed for Lake Panasoffkee for water years 2007 and 2008. Groundwater inflow was calculated as the residual term in the water budget and is considered to be the change in lake stage not accounted for by precipitation, surface-water inflows and outflows, and evaporation (fig. 30). Surface-water inflows and outflows to Lake Panasoffkee and changes in lake stage have been discussed earlier herein. Precipitation, evaporation, and the effects of OWTS on groundwater inflow are discussed in the following sections.

\section{Precipitation}

The average rainfall for water years 1930-2008 at the Inverness weather station (084289) (fig. 12) was $54.26 \mathrm{in} / \mathrm{yr}$ (National Climatic Data Center, 2009). Comparatively, the average rainfall was $52.74 \mathrm{in} / \mathrm{yr}$ at Ocala (station 086414) during water years 1932-2008, and was $51.79 \mathrm{in} / \mathrm{yr}$ at Bushnell (081163) during water years 1938-2005 (National Climatic Data Center, 2009). Rainfall totaled 38.27 and $53.44 \mathrm{in} / \mathrm{yr}$ during water years 2007 and 2008, respectively (fig. 31 and table 8), within the Lake Panasoffkee watershed. Total rainfall during the study period was 15 percent below average when compared to the historical data from Inverness.

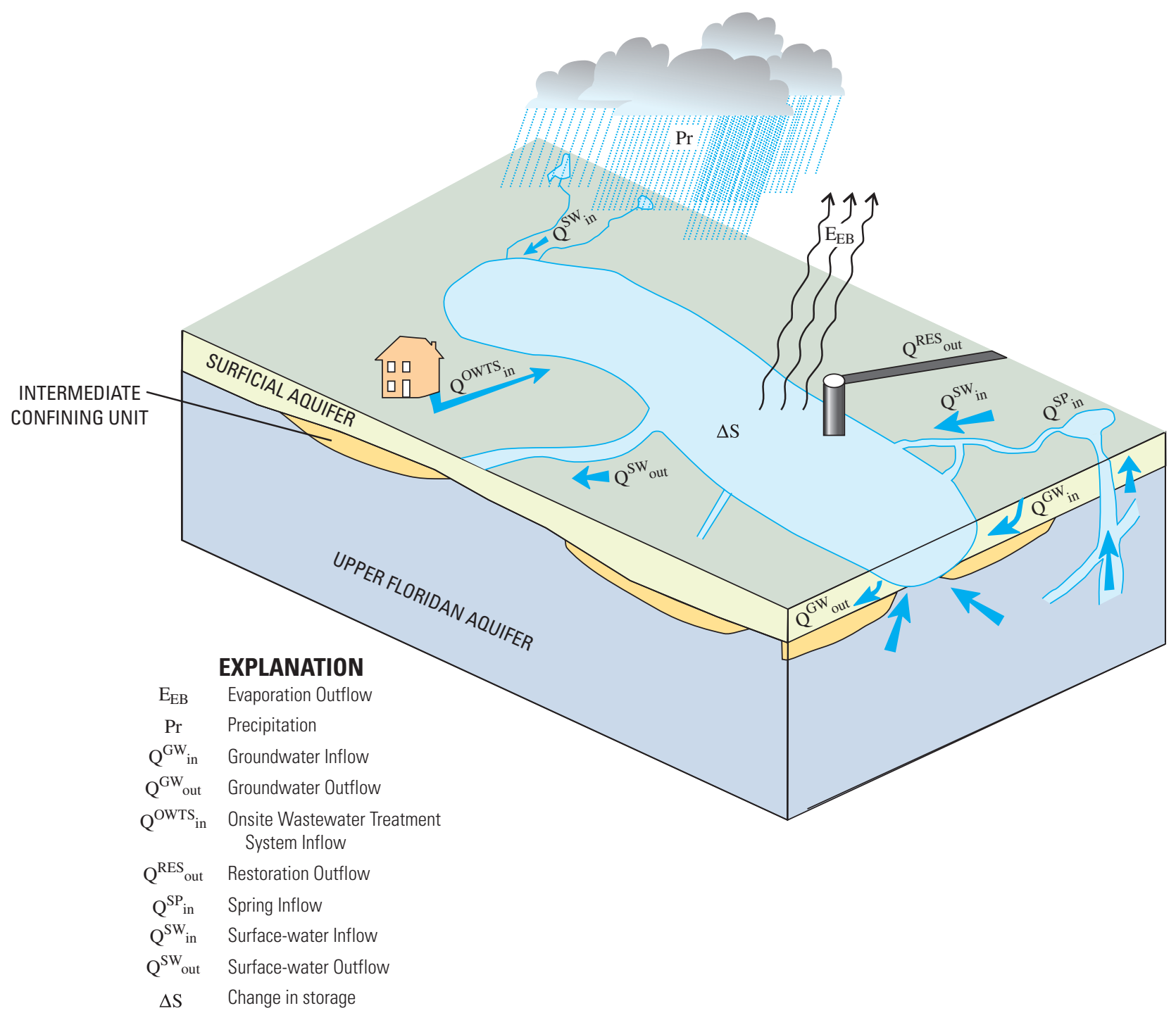

Flow direction

Figure 30. Diagram of water-budget terms. 


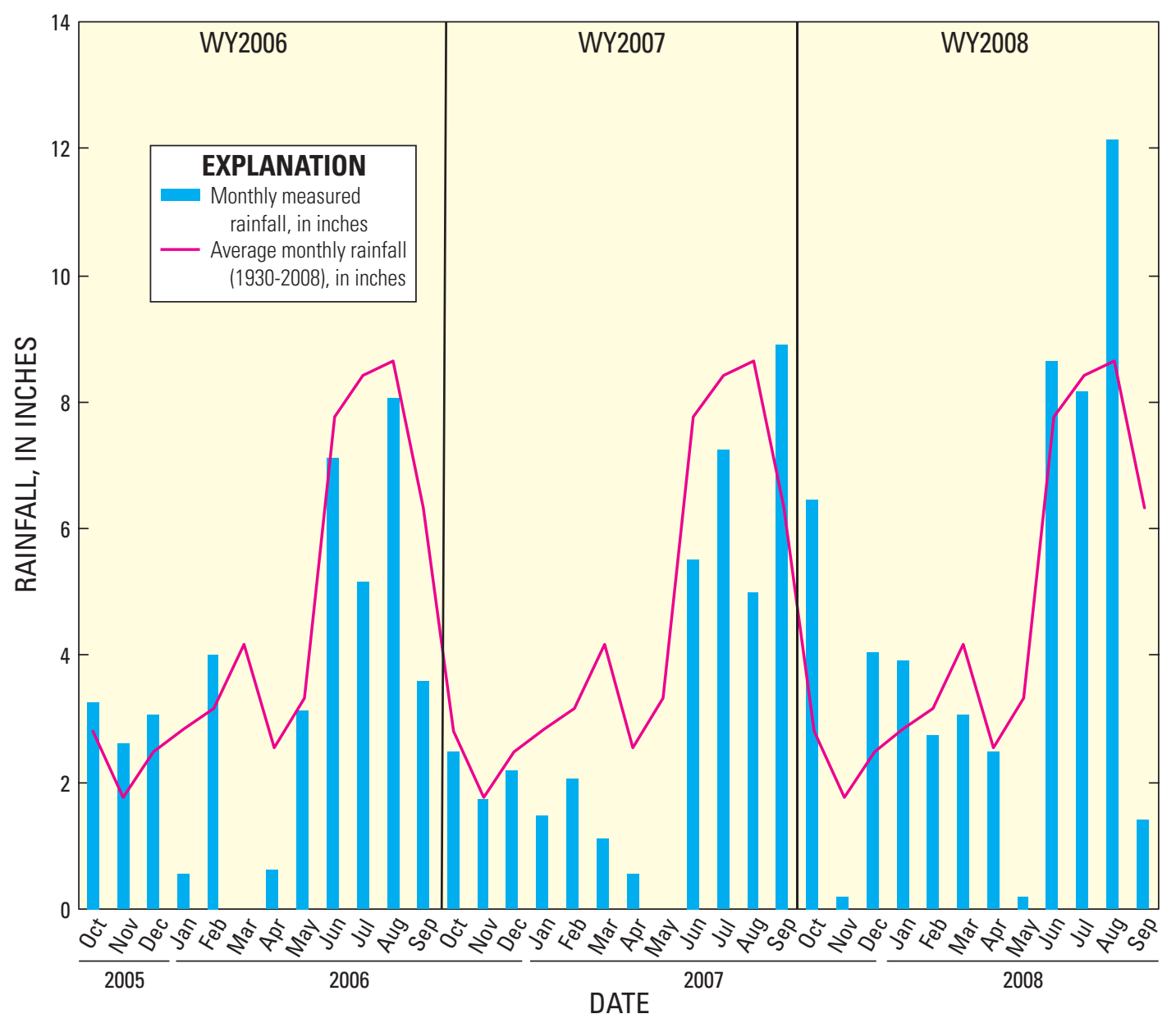

Figure 31. Monthly total rainfall in the Lake Panasoffkee watershed from October 2006 through September 2008 compared to the average monthly rainfall measured at the National Climatic Data Center station at Inverness, Florida (station 084289), October 1930 through September 2008.

Water year 2006 (just prior to the beginning of this study) was 24 percent below average. During the first year of the study (water year 2007), rainfall was 29 percent below average, with most of the rain occurring in a short period from July to September. During the second year of the study (water year 2008), rainfall was near average, but again, most of the rain fell during a few exceptionally wet months. Rainfall for October and December 2007 was 56 and 39 percent above average, respectively, whereas rainfall in January and August 2008 was 27 and 29 percent above average, respectively.

\section{Evaporation}

Lake evaporation was 90.50 in. for the 24-month study period, or 45.96 and $44.54 \mathrm{in} / \mathrm{yr}$ for water years 2007 and 2008, respectively (table 9). These values are about 17 to 28 percent lower than values measured at other central Florida lakes, which range from 54 to $63 \mathrm{in} / \mathrm{yr}$ (Lee and Swancar, 1997; Swancar and others, 2000; D.M. Sumner, U.S. Geological
Survey, written commun., 2008). After comparison with data from three other lakes in central Florida (Lake Calm, Lake Starr, and Reedy Lake; fig. 1), it was determined that most of the difference in evaporation at Lake Panasoffkee was due to the lower net radiation measured at the lake. Of all the terms in the energy-budget equation (table 9), evaporation is most sensitive to radiation fluxes (Sacks and others, 1994; Lee and Swancar, 1997). Although the cause of the reduced evaporation at Lake Panasoffkee is not completely understood because only net radiation was measured instead of measuring all radiation components separately, it is probably due to the increased reflectance of the water. Radiation differences between Lake Panasoffkee and other lakes are greatest during the middle of the day, when incoming solar radiation is greatest. The effect of increased reflectance (higher albedo) also would be greatest during midday. Compared to other lakes where evaporation has been measured, Lake Panasoffkee is shallow, and the fine-grained tan-colored carbonate bottom sediments are readily resuspended into the water column when it is windy. 
Table 8. Monthly rainfall statistics for the Lake Panasoffkee watershed for water years 2006 through 2008 compared to the average monthly rainfall at Inverness, Florida, 1930 through 2008.

[NCDC, National Climatic Data Center; WY, water year; SWFWMD, Southwest Florida Water Management District]

\begin{tabular}{|c|c|c|c|c|}
\hline \multirow[t]{2}{*}{ Month } & \multirow{2}{*}{$\begin{array}{l}\text { NCDC mean } \\
\text { monthly } \\
\text { rainfall, in } \\
\text { inches } \\
(1930 \text { through } \\
2008)^{a}\end{array}$} & \multicolumn{3}{|c|}{$\begin{array}{l}\text { Mean monthly rainfall in the } \\
\text { Lake Panasoffkee watershed for } \\
\text { WY } 2006 \text { through 2008, in inches }\end{array}$} \\
\hline & & WY $2006^{b}$ & WY $2007^{c}$ & WY $2008^{c}$ \\
\hline October & 2.80 & 3.25 & 2.49 & 6.45 \\
\hline November & 1.75 & 2.62 & 1.73 & 0.21 \\
\hline December & 2.48 & 3.06 & 2.19 & 4.05 \\
\hline January & 2.85 & 0.57 & 1.48 & 3.91 \\
\hline February & 3.15 & 4.01 & 2.06 & 2.74 \\
\hline March & 4.18 & 0.00 & 1.12 & 3.08 \\
\hline April & 2.56 & 0.62 & 0.55 & 2.49 \\
\hline May & 3.32 & 3.14 & 0.00 & 0.19 \\
\hline June & 7.76 & 7.11 & 5.52 & 8.64 \\
\hline July & 8.42 & 5.14 & 7.26 & 8.15 \\
\hline August & 8.65 & 8.05 & 4.98 & 12.14 \\
\hline September & 6.32 & 3.60 & 8.90 & 1.39 \\
\hline Total & 54.26 & 41.17 & 38.27 & 53.44 \\
\hline
\end{tabular}

${ }^{\text {a }}$ Rainfall data collected at the NCDC station 084289 (Inverness). Data gaps were filled using data collected at NCDC stations 086414 (Ocala) or 081163 (Bushnell).

${ }^{\mathrm{b}}$ Mean monthly rainfall based on data collected at SWFWMD stations 2760 (LP-6) and 6087 (Lake Panasoffkee).

${ }^{\mathrm{c}}$ Mean monthly rainfall based on data collected at USGS stations 02312675 (Little Jones Creek), 02312700 (Outlet River), and 02312720 (Withlacoochee River at Wysong Dam).

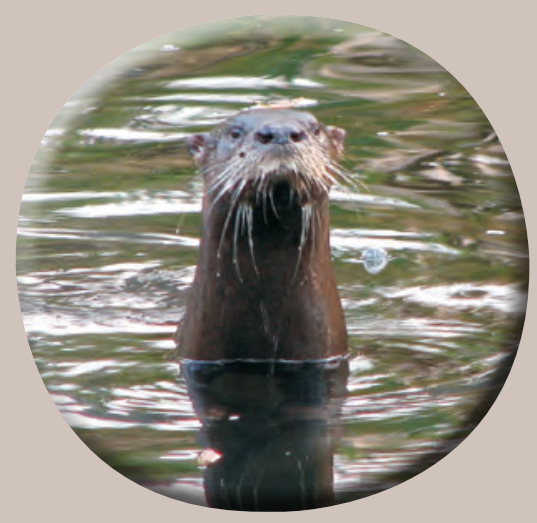

River otter (Lutra canadensis) at Shady Brook near Sumterville, Fla.; photo by W. Scott McBride
In addition, restoration dredging increased the water turbidity during this study, which also may have affected the evaporation measurement.

\section{Onsite Septic Wastewater-Treatment Systems}

To accurately quantify groundwater inflow, all processes that might affect lake stage, including the effects of OWTS, were examined. The towns surrounding Lake Panasoffkee do not offer centralized wastewater disposal, thus, it is assumed that all houses in the area utilize an OWTS for residential waste. Most OWTS in the Lake Panasoffkee watershed consist of a septic tank in which solid wastes are trapped, and an absorption field where discharged fluids infiltrate the surrounding soil (Landers and Ankcorn, 2008). It also was assumed that each parcel of land had one house, and, thus, one OWTS located within its boundaries. A geospatial query of all parcels on the west side of Lake Panasoffkee was run to identify those parcels that were located within $100 \mathrm{~m}$ (328 ft) of a canal or the lake itself. A visual inspection of these parcels of land using digital orthophotography was then conducted to determine if each parcel did indeed have a house on it. The result of this process returned a total of 737 parcels, and hence OWTS, that met the criteria (fig. 32). A high estimate of average household indoor water usage of $300 \mathrm{gal} / \mathrm{d}$ was used to calculate the annual volume of water recharged to the surficial aquifer. This value was based on a Sumter County residential per capita public water-supply usage of $162 \mathrm{gal} / \mathrm{d}$ (Southwest Florida Water Management District, 2009). A high estimate was used in the calculations to compensate for uncounted OWTS and to test whether nearly doubling per capita water usage would have a significant effect on the water budget. According to this high estimate, the annual volume of water recharging the surficial aquifer would be about $80.7 \mathrm{Mgal}\left(10.8\right.$ million $\left.\mathrm{ft}^{3}\right)$, minus losses due to evapotranspiration. In terms of the overall water budget and ignoring evapotranspiration, potential contribution to the lake from OWTS accounts for less than 1 percent of the total water inflow to the lake. Based on this annual estimate and assuming no seasonal variability, about $899,000 \mathrm{ft}^{3}$ of monthly inflow is contributed to Lake Panasoffkee from OWTS. This was accounted for in the water budget as a component of the total groundwater inflow.

\section{Ground water Inflow}

The water-budget calculations confirmed that Lake Panasoffkee nearly always gained water from groundwater inflow, with the exceptions of June and September 2007 when monthly net groundwater inflow was -0.001 and -0.97 in., respectively $\left(-13,251 \mathrm{ft}^{3}\right.$ and -11.5 million $\mathrm{ft}^{3}$; table 10). These totals are within the error of the water budget, and indicate little to no groundwater flux or that inflows and outflows were balanced (fig. 33). For all the remaining values that exceed the water-budget error, monthly 


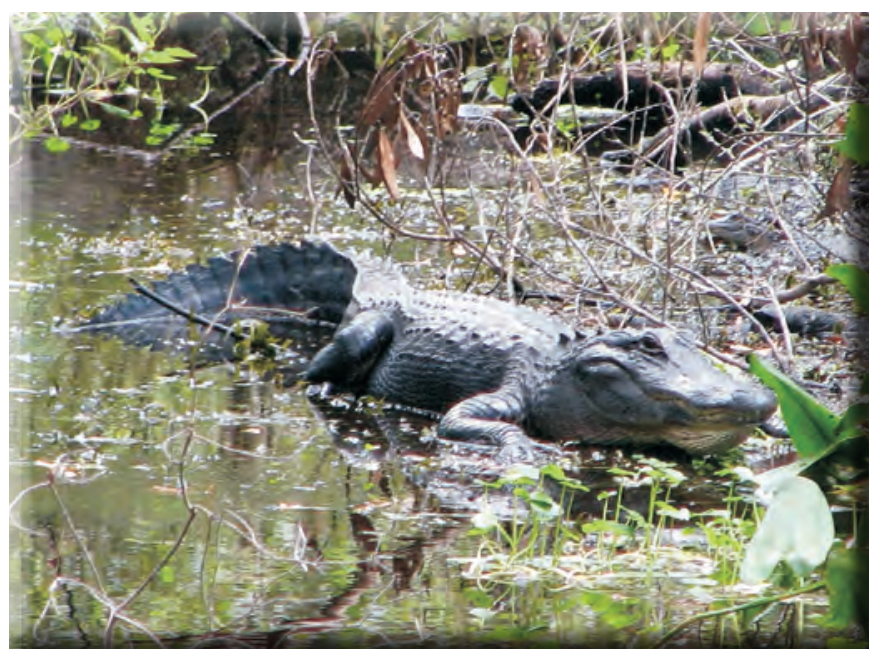

Alligator; photo by W. Scott McBride

groundwater inflow ranged from 2.53 in. $\left(43.6\right.$ million $\left.\mathrm{ft}^{3}\right)$ in December 2007 to 12.85 in. (239 million $\mathrm{ft}^{3}$ ) in August 2008. The percent contribution of groundwater inflow to total inflows for months when groundwater inflow exceeded the error ranged from 11 percent in October 2007 to 50 percent in May 2007, with a total contribution of 29 percent over the 2 -year data-collection period. By comparison, surface-water inflow for the 2-year study period was 50 percent of the total inflow and rainfall was 21 percent of the total inflow.

The percentage of total inflow received from groundwater inflow (29 percent) at Lake Panasoffkee is typical for lakes in central Florida. Sacks (2002) used the isotope mass-balance approach to calculate the groundwater inflow to 81 lakes in central Florida, categorizing lakes as low, medium, or high

Table 9. Summary of energy-budget data for Lake Panasoffkee from October 2006 through September 2008.

[Ta, air temperature; To, surface-water temperature; Ea, vapor pressure at air temperature; Eo, saturation vapor pressure at water-surface temperature; $\mathrm{cal} / \mathrm{cm}^{2} / \mathrm{d}$, calories per square centimeter per day; mb, millibars; ${ }^{\circ} \mathrm{C}$, degrees Celsius; Qx, change in stored energy; Qv, energy advected to the lake from rainfall; cal/g, calories per gram; cm/day, centimeters per day; in., inch; WY, water year]

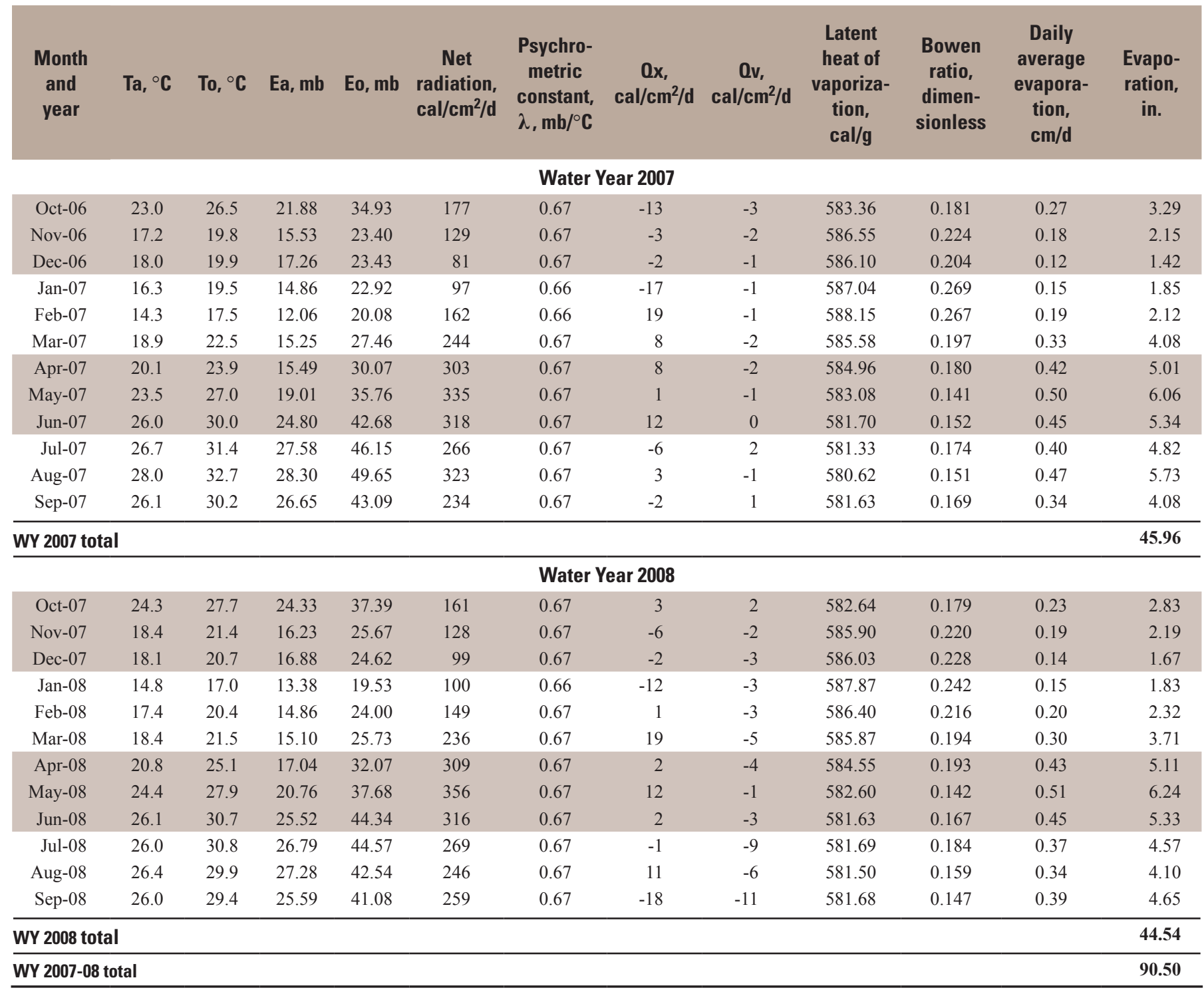




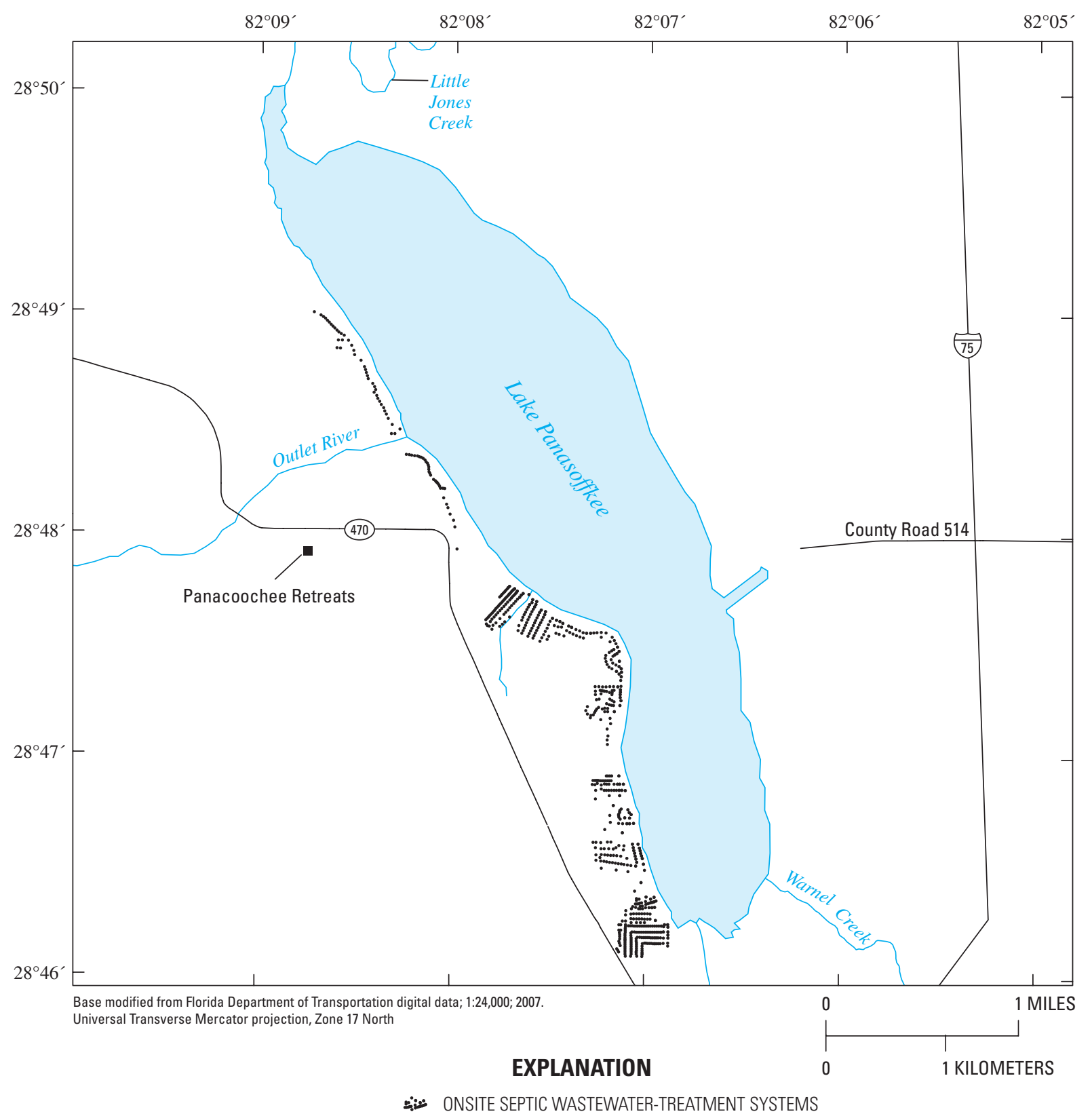

Figure 32. Location of onsite septic wastewater-treatment systems within 100 meters (328 feet) of Lake Panasoffkee or canals.

groundwater inflow lakes depending on the percentage of total inflow received as groundwater inflow. "Low" lakes receive less than 25 percent, "medium" lakes receive between 25 and 50 percent, and "high" lakes receive greater than 50 percent of total inflow as groundwater inflow. Lake Panasoffkee is within the "medium" category because it receives between 25 and 50 percent of its total inflow as groundwater inflow. Sacks (2002) found that lakes in upland areas typically fall in the "medium" to "high" category of groundwater inflow lakes, whereas lakes in the coastal lowlands usually fall into the "low" groundwater inflow lakes category. Lakes selected for the Sacks (2002) study were mostly seepage lakes, however, with no surfacewater inflows or outflows. So although Lake Panasoffkee falls in the "medium" category, the comparison is hampered by the fact that it is a more surface water dominated system than many Florida lakes. 


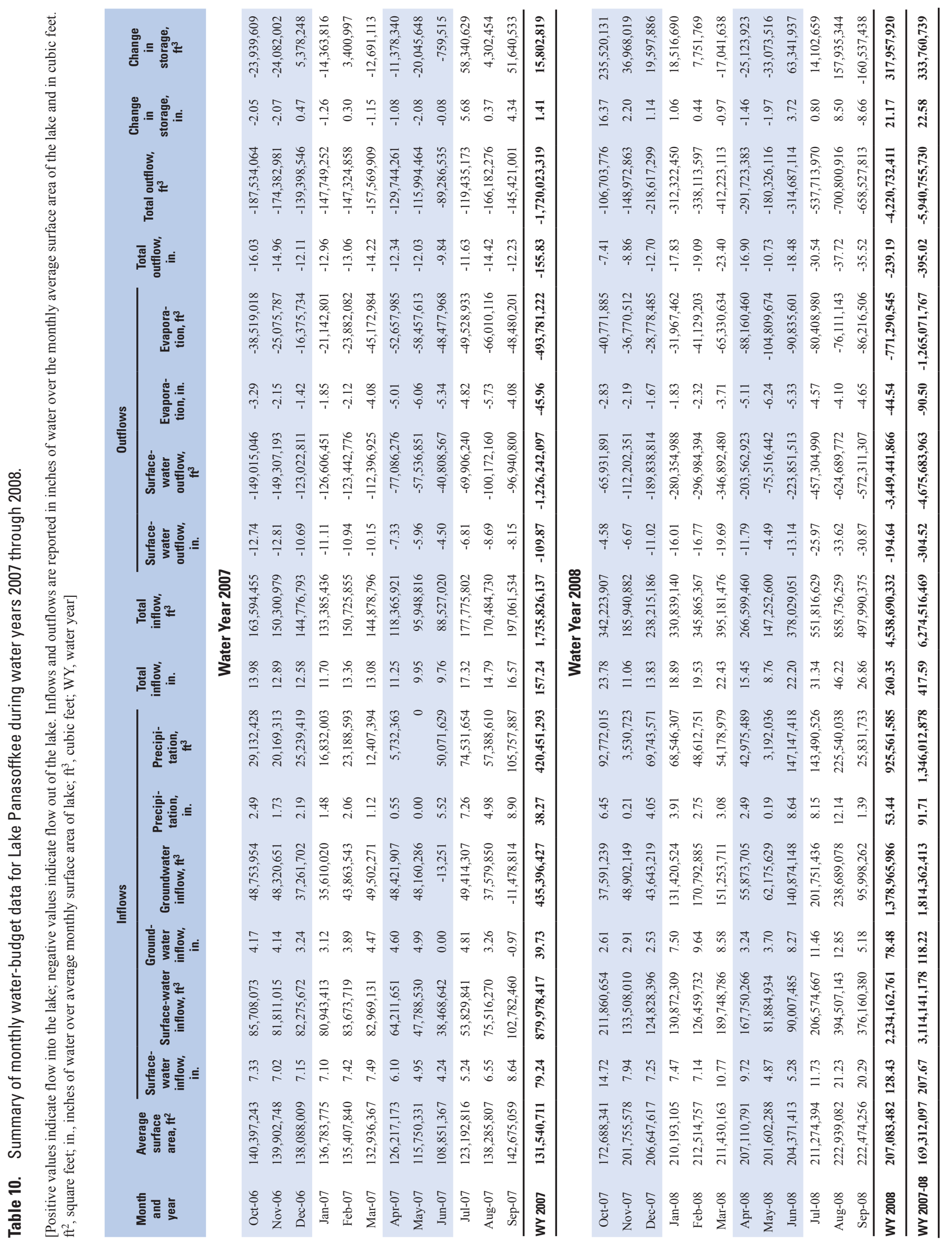




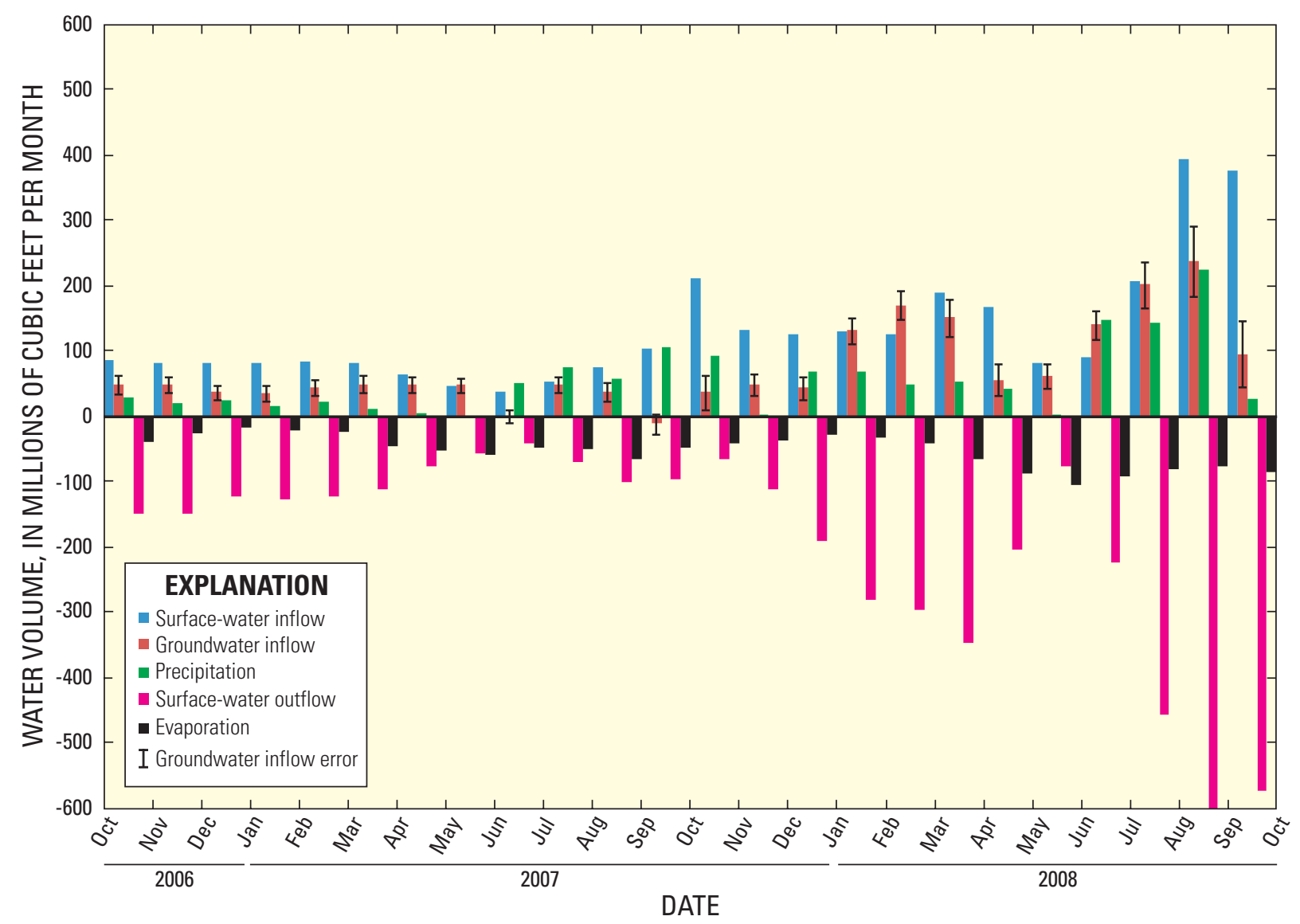

Figure 33. Summary of monthly water-budget data for Lake Panasoffkee during water years 2007 through 2008.

The source of the groundwater inflow to Lake Panasoffkee is also unusual among lakes in central Florida. Lake Panasoffkee receives most of its groundwater inflow from the Upper Floridan aquifer. Sacks (2002) found that both the upland and lowland lakes in that study received groundwater inflow from the surficial aquifer. Most of the seepage lakes studied by Sacks (2002) were formed by karst processes when cavities in the underlying limestone collapsed, causing overlying sands and clays to subside into the collapse feature and leaving depressions at land surface (Tihansky and others, 1996). The depressions then filled with water from the surficial aquifer, creating the lakes. These lakes are in a recharge setting with respect to the Upper Floridan aquifer, and water from the lakes recharges the Upper Floridan aquifer preferentially through disruptions in the intermediate confining unit caused by the initial collapse (Lee and Swancar, 1997).

The volume of groundwater inflow received by Lake Panasoffkee also distinguishes it from other lakes in central Florida. Although the percentage of total inflow received by Lake Panasoffkee from groundwater inflow is similar to that of other lakes, the volume of groundwater inflow is not. The largest lowland lake studied by Sacks (2002) had a surface area of 267 acres and an estimated groundwater inflow of $19.3 \mathrm{in} / \mathrm{yr}\left(19\right.$ million $\left.\mathrm{ft}^{3} / \mathrm{yr}\right)$; the largest highland lake, with a surface area of 5,074 acres, had an estimated groundwaterinflow rate of $16 \mathrm{in} / \mathrm{yr}$ (294 million $\mathrm{ft}^{3} / \mathrm{yr}$ ). Both lakes receive smaller volumes of groundwater inflow than Lake Panasoffkee, which had an average surface area of 3,020 acres in water year 2007 and 4,753 acres in water year 2008. Groundwater inflow to Lake Panasoffkee was $39.73 \mathrm{in} / \mathrm{yr}$ (435 million $\mathrm{ft}^{3} / \mathrm{yr}$ ) during water year 2007 and $78.48 \mathrm{in} / \mathrm{yr}$ (1.38 billion $\mathrm{ft}^{3} / \mathrm{yr}$ ) during water year 2008 (table 10). This was double that of the lake with the largest groundwater inflow reported by Sacks (2002).

The volume of groundwater contributed from the Upper Floridan aquifer to Lake Panasoffkee is even more pronounced if the sources of the surface-water inflows are considered, because as much as 78 percent of the total surfacewater inflow during the four seepage runs was contributed by spring flow. If 78 percent of the total surface-water inflow to Lake Panasoffkee for March 2008 (8.40 in. or 
148 million $\mathrm{ft}^{3}$ ) is added to the total groundwater inflow for that month, the volume of groundwater contributed to Lake Panasoffkee nearly doubles from 8.58 in. (151 million $\mathrm{ft}^{3}$ ) to 16.98 in. ( 299 million $\left.\mathrm{ft}^{3}\right)$. The combined spring flow and groundwater inflow into Lake Panasoffkee is the equivalent of a first-magnitude spring. A spring must produce at least 261 million $\mathrm{ft}^{3}$ per month $\left(100 \mathrm{ft}^{3} / \mathrm{s}\right)$ to be classified as a firstmagnitude spring (Spechler and Schiffer, 1995). Under wetter hydrologic conditions, groundwater inflow alone would meet these criteria at Lake Panasoffkee and nearly did so in August 2008 when groundwater inflow averaged about $91 \mathrm{ft}^{3} / \mathrm{s}$.

\section{Comparisons to Earlier Water-Budget Study}

A water budget was calculated for Lake Panasoffkee by CH2M Hill (1995) from May 1992 through April 1993 (table 11). Water-budget data from the current study were computed for the May 2007 through April 2008 period so that the results of the two studies could be compared. The comparison is given only in cubic feet of water, not in inches of water over the average surface area of the lake, because 3 months of lake stage data were missing during the earlier study. Data from the earlier study were converted from acre feet to cubic feet.

Table 11. Comparison of the May 1992 through April 1993 and May 2007 through April 2008 Lake Panasoffkee water budgets.

[Positive values indicate flow into the lake; negative values indicate flow out of the lake. All flows are expressed in cubic feet. Table values are rounded from the values used in the actual water budget calculations]

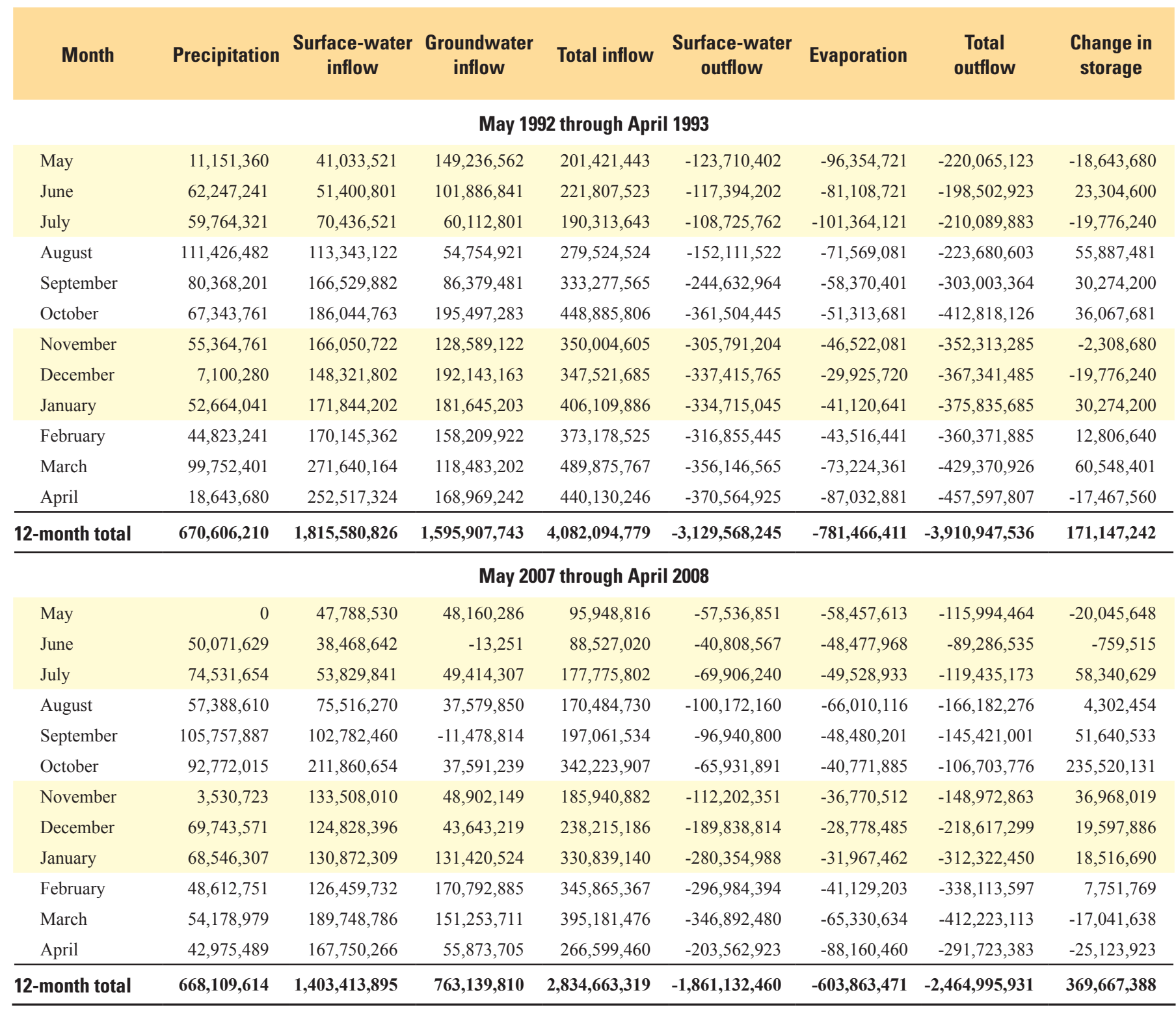


The volume of precipitation received by Lake Panasoffkee during the two periods was similar, as both studies were conducted during a drought. Inflow to Lake Panasoffkee directly from rainfall was 671 million $\mathrm{ft}^{3} / \mathrm{yr}$ during the preceding study and 668 million $\mathrm{ft}^{3} / \mathrm{yr}$ during May 2007 through April 2008 (table 11). Total rainfall was $41.01 \mathrm{in} / \mathrm{yr}$ at Lake Panasoffkee during the earlier study (CH2M Hill, 1995) and $49.59 \mathrm{in} / \mathrm{yr}$ from May 2007 through April 2008 (table 8). The discrepancy in the amount of rainfall between the two periods compared to the volume of inflow received from rainfall probably results from a difference in average lake surface area between the two studies. During the first study, Lake Panasoffkee remained above $38.50 \mathrm{ft}$ NGVD 29 for the entire study period and was above $39.50 \mathrm{ft} \mathrm{NGVD} 29$ for more than half of the study period. During this study, water levels were about $37.50 \mathrm{ft}$ NGVD 29 during the summer of 2007, rose to about $39.00 \mathrm{ft} \mathrm{NGVD} 29$ in the fall, and mostly remained between 39.00 and $39.50 \mathrm{ft}$ NGVD 29 through April 2008. Small changes in water level can result in large changes in lake surface area when the topographic relief of a region is low. Because water levels were higher, on average, during the earlier study, the surface area of the lake was presumably greater, resulting in similar volumes of input received directly from rainfall despite an approximate 8.5 -in. difference in rainfall.

Surface-water inflow was similar during both study periods, whereas groundwater inflow was not. CH2M Hill (1995) reported surface-water inflows of 1.8 billion $\mathrm{ft}^{3} / \mathrm{yr}$, compared to 1.4 billion $\mathrm{ft}^{3} / \mathrm{yr}$ for May 2007 through April 2008 (table 11). The 12-month period prior to each period was substantially different. Rainfall at the NCDC weather station at Inverness, Florida (fig. 12), from May 1991 through April 1992 was well above average with $68.88 \mathrm{in} / \mathrm{yr}$ of rainfall, whereas rainfall was only $38.29 \mathrm{in} / \mathrm{yr}$ between May 2006 and April 2007. The rainfall surplus during the earlier study and the deficit during the recent period are reflected in the differences in groundwater inflow data for each study period. Lake Panasoffkee received almost 1.6 billion $\mathrm{ft}^{3} / \mathrm{yr}$ of groundwater inflow between May 1992 and April 1993, and only half that amount, 763 million $\mathrm{ft}^{3} / \mathrm{yr}^{\mathrm{r}}$ between May 2007 and April 2008 (table 11).

Total inflows to Lake Panasoffkee for the recent period were about 69 percent of the total inflows determined during the 1992-93 study period, mostly because of the decrease in groundwater inflow, but also because the lake received no flow from Big Jones Creek (fig. 1) between May 2007 and April 2008 during the current study. Big Jones Creek was not flowing because surficial aquifer levels, the primary water source for this stream, were lower than the elevation of the creek channel during this time. Total outflows from Lake Panasoffkee, including both surface water and evaporation, were 3.9 billion $\mathrm{ft}^{3} / \mathrm{yr}$ from May 1992 through April 1993 and 2.5 billion $\mathrm{ft}^{3} / \mathrm{yr}$ from May 2007 through April 2008 (table 11). The lower total outflows for the latter period are primarily a result of the lower volumes of surface-water and groundwater inflow to Lake Panasoffkee, with groundwater inflow being the largest difference. Lake evaporation was estimated to be 781 million $\mathrm{ft}^{3} / \mathrm{yr}$ in the 1992-93 study period, whereas measured evaporation was 604 million $\mathrm{ft}^{3} / \mathrm{yr}$ for the 2007-8 period. The CH2M Hill study (1995) may have overestimated the volume of evaporation from Lake Panasoffkee because that study used pan evaporation values that were not determined at Lake Panasoffkee. This study established that the evaporation rate at Lake Panasoffkee is less than that of other lakes in the area.

\section{Water Chemistry}

This section describes the water chemistry of Lake Panasoffkee, its tributaries, and selected springs and wells in the watershed. Included in the discussion are conditions in the surficial aquifer and Upper Floridan aquifer, and, to a lesser extent, the Lower Floridan aquifer below middle confining unit I. Results of water chemistry, isotopic, and age-dating analyses of surface and groundwaters in the Lake Panasoffkee watershed provide independent information to support the hydrologic data discussed earlier, or in some cases provide new information, that aid in our understanding of the Lake Panasoffkee hydrologic system.

Drought conditions prevailed during the two sampling periods, with surface water and groundwater at below-average levels. Water-chemistry data from samples collected during non-drought conditions would likely result in appreciably different water chemistry because surface water and the surficial aquifer would have a greater effect on the hydrologic system. The advantage of collecting samples during the drought is that the effects of the deep groundwater system on Lake Panasoffkee can be easily determined from data analysis. The effect of deep groundwater on the lake would be more difficult to determine under wet conditions because of dilution of lake water from surface water and shallow groundwater.

\section{Major lons}

Major ions are those ions commonly found in ambient waters in concentrations exceeding $1 \mathrm{mg} / \mathrm{L}$ (Hem, 1992); they form as the result of innate processes such as geochemical weathering and atmospheric deposition. Major ions include positively charged cations, such as calcium, magnesium, sodium, and potassium, and negatively charged anions, such as sulfate, chloride, fluoride, nitrate, bicarbonate, and carbonate. Rainfall typically contains low concentrations of major ions, but these increase in concentration after water reaches land surface and begins to interact with soils, rocks, and minerals. The concentration of major ions in a water sample can be an indication of the "maturity" of the water, and helps delineate the flowpath it has taken through the hydrologic system.

As water percolates through soil, it becomes increasingly acidic (lowering the $\mathrm{pH}$ ) as it reacts with carbon dioxide $\left(\mathrm{CO}_{2}\right)$ in the soil to form carbonic acid $\left(\mathrm{H}_{2} \mathrm{CO}_{3}\right)$. Natural organic acids, such as humic acid, also can increase the 
acidity of water. Carbonic acid reacts with limestone in the groundwater system to liberate calcium $\left(\mathrm{Ca}^{2+}\right)$ and bicarbonate ( $\left.\mathrm{HCO}_{3}-\right)$ ions (Jones and others, 1996). As water enters the slower moving groundwater-flow system, concentrations of major ions further increase because the water is in close contact with Earth materials for long time periods.

Major ion data from the Lake Panasoffkee water samples that were collected during July 2007 and December 2008 through January 2009 are plotted on trilinear diagrams (fig. 34, app. 2). In this study, despite the widely varying sources of water sampled, the majority of samples were calcium-bicarbonate water types. The primary source of calcium bicarbonate in the study area is limestone of the Floridan aquifer system; therefore, almost all of the water samples contain at least some percentage of groundwater. Groundwater can interact with surface water by way of spring discharge or through diffuse inflow of groundwater through stream or lakebeds when the head in the Upper Floridan aquifer is higher than that of the overlying surficial aquifer.

Trilinear diagrams indicate three distinct groups of samples. Groups $A$ and $B$ are similar chemically and appear adjacent to one another on the plots. Group $A$ samples plot in the lower left corner of the trilinear diagram, indicating that these samples are "pure" calcium-bicarbonate type waters. Group $B$ samples plot just above group $A$ samples and are still calcium-bicarbonate type waters, but contain a higher fraction of sulfate than group $A$, indicating mixing with a calcium-sulfate type water. Water from ROMP LP-4 (QW6), the sole sample in group $C$, plots in the upper tip of the trilinear diagram and was a calcium-sulfate type water for both samples (fig. 34, table 4, and app. 2). The most likely source of calcium sulfate is gypsum, which is found deep in the Upper Floridan aquifer in the Avon Park Formation.

In July 2007, group $A$ samples included all of the groundwater samples collected in the surficial aquifer, all of the springs except site QW22, three Upper Floridan aquifer samples (QW1, QW3, and QW11), and one surface-water sample (QW23) (fig. 34A, table 4, and app. 2). The three Upper Floridan aquifer samples in group $A$ are all from wells located near the northern and eastern shoreline of Lake Panasoffkee in recharge areas. Group $B$ samples included all of the surface-water samples (lake and tributary), except the aforementioned QW23 sample. QW22 is the sole spring in group $B$, and is located in a canal on the southwestern shore of Lake Panasoffkee with five other spring vents. These are the only springs in the lake watershed located west of Lake Panasoffkee. The final three samples in group $B$ were from Upper Floridan aquifer wells located near the western shore of Lake Panasoffkee.

The December 2008 through January 2009 trilinear plot reveals the same three sample groups as in July 2007, but some of the sites shifted between groups $A$ and $B$ (fig. 34B). Group $B$, the mixed calcium-bicarbonate/calcium-sulfate water type, contained the same Upper Floridan aquifer and spring sites as in July 2007 as well as QW13 and QW15, two new surficial aquifer sites not previously sampled in
July 2007. Group $A$ contained all remaining samples except the aforementioned Upper Floridan aquifer sample in Group $C$ from QW6. All of the surface-water sites that had been in group $B$ in July 2007 shifted to group $A$ in the second sampling event. Group $A$ also included sites QW17, a deep Upper Floridan aquifer well, and QW16, a Lower Floridan aquifer well installed below middle confining unit I. Neither of these sites was sampled in July 2007 (figs. 14 and 34B, table 4, and app. 2).

The lower sulfate concentrations detected in most of the surface-water samples collected in December 2008 through January 2009 were likely the result of higher aquifer levels. In July 2007, aquifer levels in both the surficial and Upper Floridan aquifers were at the lowest point of the study period. By the second sampling event, aquifer levels had recovered partially because of rainfall during the summer of 2008, which resulted in greater volumes of groundwater inflow to the lake from the surficial and shallow Upper Floridan aquifers (fig. 33). The water containing higher concentrations of sulfate likely comes from deep within the Upper Floridan aquifer. Lake Panasoffkee probably regularly receives a small percentage of its groundwater inflow from the deep Upper Floridan aquifer, but this source would be difficult to detect under normal hydrologic conditions because of dilution from shallow and surface sources.

Differences in head and major ion data indicate that the primary source of spring flow in the watershed is the shallow part of the Upper Floridan aquifer, which is generally low in sulfate. However, the groundwater chemistry of the Upper Floridan aquifer is distinctly different in a small area south and southwest of Lake Panasoffkee compared to conditions elsewhere in the watershed. Water in the Upper Floridan aquifer in west-central Florida is usually chemically stratified, with higher sulfate concentrations present deeper in the aquifer because of an increase in gypsum and anhydrite rocks with depth (Faulkner, 1973). Sacks (1996) analyzed data from rock cores collected from the shallow Upper Floridan aquifer near Lake Panasoffkee, and determined that gypsum was not present in sufficient quantities to explain the observed sulfate concentrations found in water samples from that formation. Sulfate concentrations in west-central Florida are typically less than $30 \mathrm{mg} / \mathrm{L}$ in surface waters, the surficial aquifer, and the Upper Floridan aquifer. Sacks used the geochemical mass-balance model NETPATH (Plummer and others, 1991) to determine that the most likely source of water containing greater than $30 \mathrm{mg} / \mathrm{L}$ of sulfate in the shallow Upper Floridan aquifer is water upwelling from deep within the Upper Floridan aquifer. Observed values of sulfate are consistent with those found in middle confining unit II or near the base of the Upper Floridan aquifer. Water deep in the Upper Floridan aquifer is part of a much slower regional flow system that typically bypasses inland discharge areas to discharge near or offshore from the coast (Southwest Florida Water Management District, 1991). 


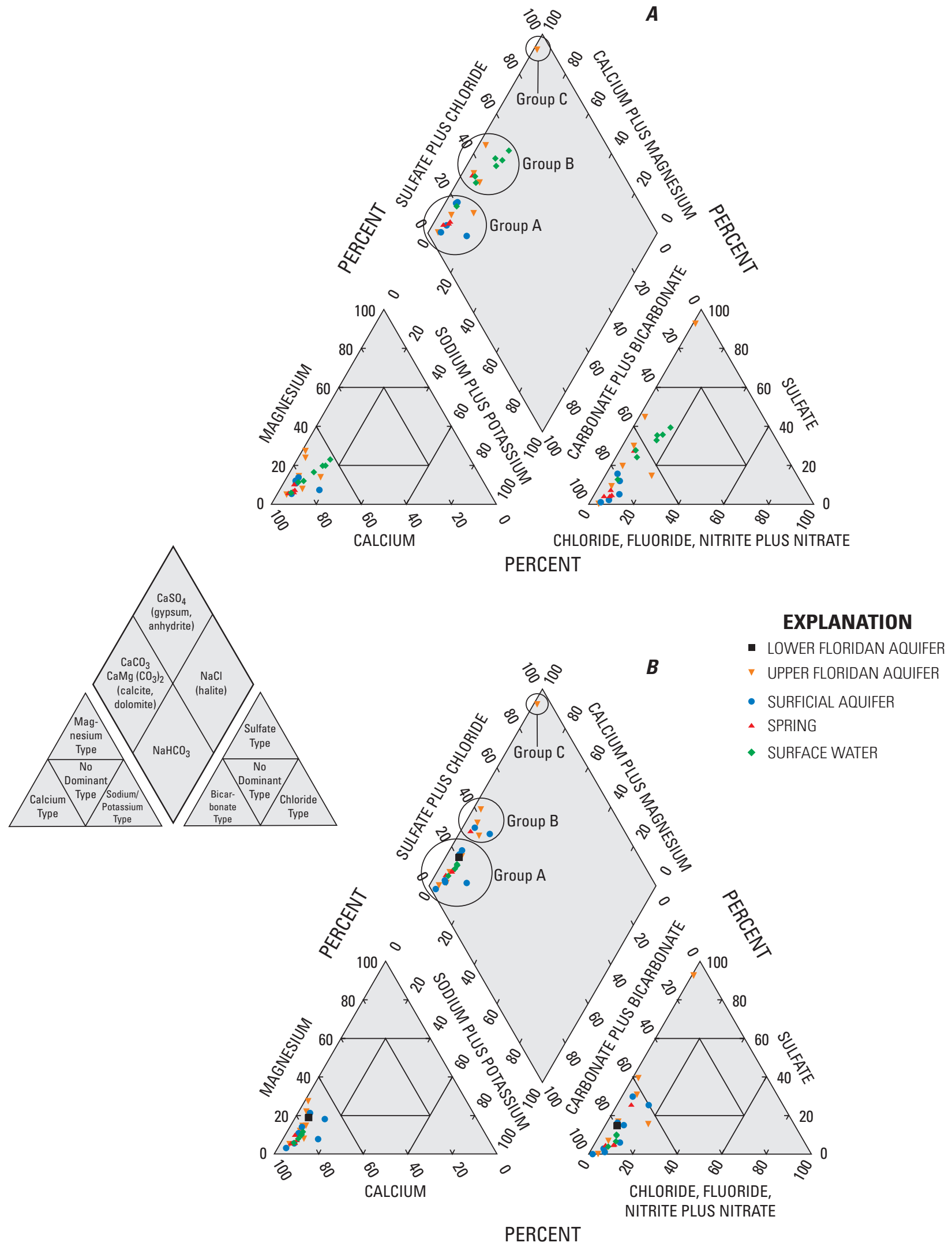

Figure 34. Water types from water-quality samples collected in the Lake Panasoffkee watershed during $A$, July 2007 and B, December 2008 through January 2009. 


\section{Sources of Sulfate}

Most of the region around Lake Panasoffkee is an aquifer recharge area, but there are focused areas of discharge associated with Lake Panasoffkee and the Withlacoochee River. One possible mechanism driving the upwelling of water from deep within the Upper Floridan aquifer is aquifer discharge to Lake Panasoffkee and the Withlacoochee River (Sacks, 1996). Rapid groundwater flow within the shallow, more permeable parts of the Upper Floridan aquifer may contribute to the upwelling. However, similar groundwater upwelling anomalies also have been observed in recharge areas of Marion County (Sacks, 1996).

Upwelling groundwater might also be related to vertical groundwater flow through fractures and faults associated with the Ocala structural high, which connect deeper and shallower parts of the Floridan aquifer system (Southwest Florida Water Management District, 1991). Jones and others (1996) noted an area of high sulfate concentrations in the Upper Floridan aquifer distributed along a northeast-southwest trending line stretching from northwest of Ocala to near Dunnellon (fig. 2). Vernon (1951) mapped possible fracture traces on the Florida peninsula based on physiographic expressions. Five of these traces pass near or through the Lake Panasoffkee area, trending in both northeast-southwest and northwest-southeast directions. The long, narrow shape of Lake Panasoffkee suggests that it may have formed along a fault, but there is no physical evidence of this other than topography.

Recent deep core samples collected by the SWFWMD at well sites ROMP 119.5, about 20 mi northwest of Lake Panasoffkee, and ROMP WR-6B, about 15 mi southwest of Lake Panasoffkee, did not intercept middle confining unit I (figs. 19-20) (Jim Clayton and Jason LaRoche, Southwest Florida Water Management District, written commun., 2008-2009). Middle confining unit II was present at both sites, but was absent $7 \mathrm{mi}$ west of Lake Panasoffkee at site QW16 (fig. 14 and table 4). The SWFWMD collected waterquality samples while drilling ROMP sites 119.5 and WR-6B and found the water beneath middle confining unit II to be highly mineralized and nonpotable without treatment (Jason LaRoche, Southwest Florida Water Management District, written commun., 2008). At site QW16 (fig. 14 and table 4), the quality of the water in the Lower Floridan aquifer (beneath middle confining unit I) was similar to that found deep in the Upper Floridan aquifer at QW17 (above middle confining unit I). This result is an indication that middle confining unit I is leaky, and that water exchange occurs between the Upper and Lower Floridan aquifers in this area. O'Reilly and others (2002) studied the hydrogeology and water-quality characteristics of the Lower Floridan aquifer in east-central Florida below middle confining unit I, and found head differences between the Upper and Lower Floridan aquifers to be highly variable throughout east-central Florida. The differences in head were attributed to the integrity (or lack thereof) of middle confining unit I. O'Reilly reclassifies middle confining unit I as the middle semiconfining unit based on this new data that were not available to Miller (1986).

\section{Isotopes}

Isotopic analyses of water samples are powerful tools for describing groundwater-flow patterns and surface-water and groundwater interactions. In a hydrologic system like the Lake Panasoffkee watershed, where major ion chemistry is similar throughout the system, isotopes are useful for identifying sources of groundwater to the lake.

\section{Strontium}

The similarity between the ${ }^{87} \mathrm{Sr} /{ }^{86} \mathrm{Sr}$ ratios found in water samples from Lake Panasoffkee and water samples from Upper Floridan aquifer wells installed in the Avon Park Formation south and southwest of Lake Panasoffkee suggests that water originating from this part of the Avon Park Formation contributes groundwater inflow to Lake Panasoffkee. Ratios of ${ }^{87} \mathrm{Sr} /{ }^{86} \mathrm{Sr}$ in all water samples collected in July 2007 varied from 0.70776 to 0.70856 (fig. $35 \mathrm{~A}$ and table 12). The ${ }^{87} \mathrm{Sr} /{ }^{86} \mathrm{Sr}$ ratio is inversely related to the age of the aquifer materials the water samples have been in contact with: older samples have lower ${ }^{87} \mathrm{Sr} /{ }^{86} \mathrm{Sr}$ ratios. Water samples from Upper Floridan aquifer wells QW5, QW6, and QW9 (fig. 14 and table 4), located south and southwest of Lake Panasoffkee, had the lowest ${ }^{87} \mathrm{Sr} /{ }^{86} \mathrm{Sr}$ ratios in the study area.

The ${ }^{87} \mathrm{Sr} /{ }^{86} \mathrm{Sr}$ ratio data collected in December 2008 through January 2009 were similar to the data collected in July 2007 (fig. 35B and table 12). Spring site QW22 and surface-water samples QW25 and QW27 had only a slightly higher overall ratio of ${ }^{87} \mathrm{Sr} /{ }^{86} \mathrm{Sr}$ than the corresponding July 2007 samples (fig. 14 and table 4). DePaolo and Ingram (1985) analyzed rock cores from the Avon Park Formation and determined that the strontium isotope ratio of this formation ranged from 0.7077 to 0.7078 . This value is consistent with the ${ }^{87} \mathrm{Sr} /{ }^{86} \mathrm{Sr}$ ratios obtained in the groundwater, spring, and surface-water samples in this study.

Water samples from both Shady Brook and Little Jones Creek, the primary contributors of surface-water flow to Lake Panasoffkee, both had higher strontium isotope ratios than samples from Lake Panasoffkee. This suggests that although the lake receives water from the Avon Park Formation, this water does not come from the lakes tributaries. Site QW22 supplies water directly to Lake Panasoffkee and has a similar ${ }^{87} \mathrm{Sr} /{ }^{86} \mathrm{Sr}$ ratio as the lake water, but these springs are a minor source of water compared to the tributaries. The ${ }^{87} \mathrm{Sr} /{ }^{86} \mathrm{Sr}$ ratios in water samples from piezometers driven into the lakebed in December 2008 (QW13 and QW15) were nearly identical to samples collected from the deeper Upper Floridan aquifer wells south and southwest of Lake Panasoffkee (QW5, QW6, and QW9) (figs. 14 and 35B, and tables 4 and 12). 

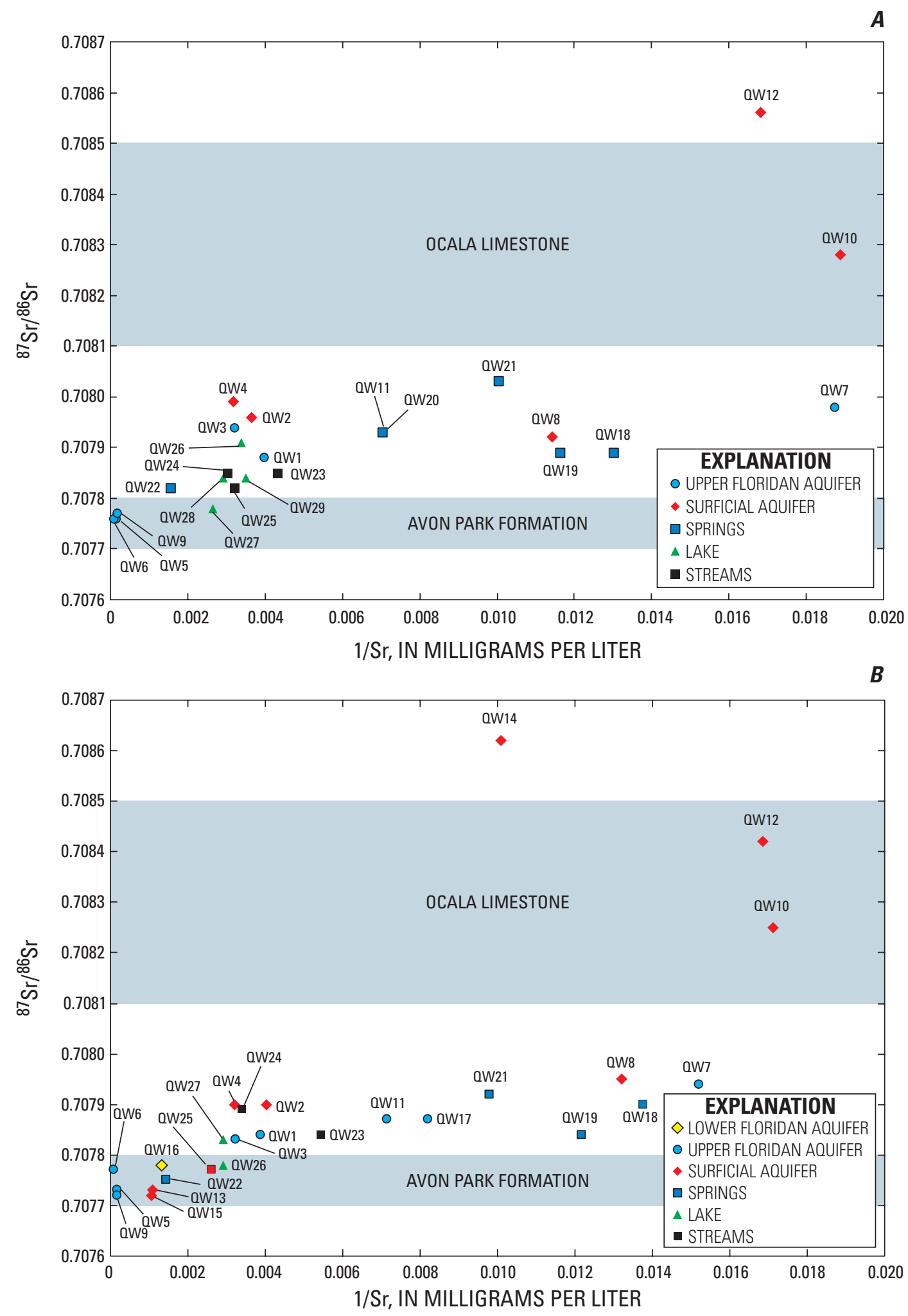

Figure 35. Relation between strontium isotope ratios and the reciprocal of the strontium concentration in water samples from the Lake Panasoffkee study area for $A$, July 2007 and $B$, December 2008 through January 2009. Blue bands indicate the range of values measured in rock cores collected from the specified formations. 
Table 12. Strontium, hydrogen, and oxygen isotope data collected from select groundwater, surface-water, and spring sites in the Lake Panasoffkee study area, July 2007 and December 2008 through January 2009.

[yyyy/mm/dd, year/month/day; EST, Eastern Standard Time; ft, feet; per mil, parts per thousand; UFA, Upper Floridan aquifer; SA, surficial aquifer; SPG, spring; SW, surface water; LFA, Lower Floridan aquifer]

\begin{tabular}{|c|c|c|c|c|c|c|c|c|}
\hline $\begin{array}{l}\text { Refer- } \\
\text { ence } \\
\text { number } \\
\text { (fig. 14) }\end{array}$ & $\begin{array}{l}\text { Site } \\
\text { type }\end{array}$ & $\begin{array}{l}\text { USGS site } \\
\text { identification } \\
\text { number }\end{array}$ & Station name & $\begin{array}{c}\text { Date } \\
\text { (yvyv/mm/dd) }\end{array}$ & $\begin{array}{l}\text { Time } \\
\text { (EST) }\end{array}$ & $\begin{array}{l}\text { Strontium } \\
87 / 86 \text { ratio }\end{array}$ & $\begin{array}{c}\text { Delta } \\
\text { hydrogen } \\
2 / 1 \text { ratio } \\
\text { (per mil) }\end{array}$ & $\begin{array}{c}\text { Delta } \\
\text { oxygen } \\
\text { 18/16 ratio } \\
\text { (per mil) }\end{array}$ \\
\hline
\end{tabular}

July 2007 Sampling Event

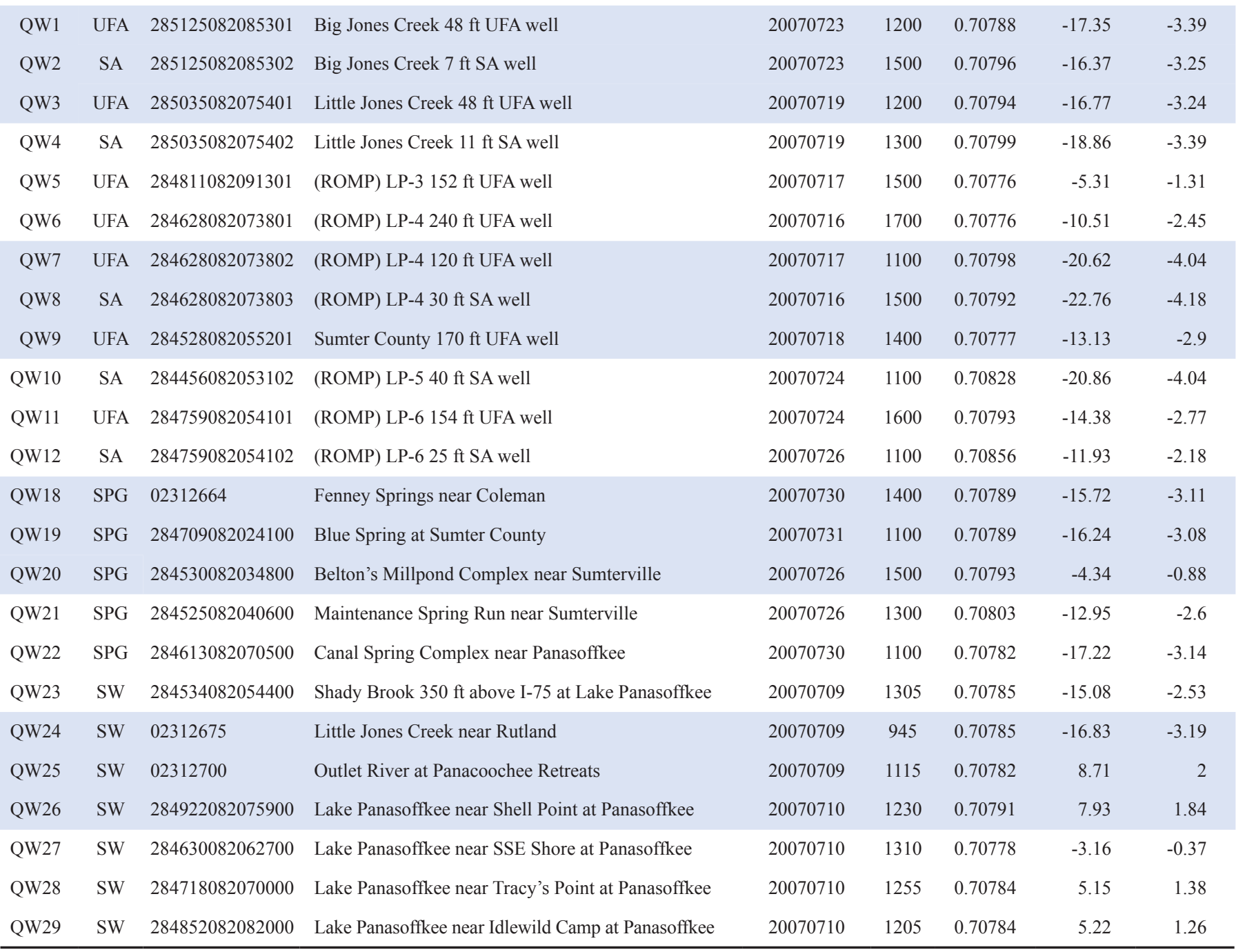

December 2008 through January 2009 Sampling Event

\begin{tabular}{lllllllll} 
QW1 & UFA & 285125082085301 & Big Jones Creek 48 ft UFA well & 20081203 & 1230 & 0.70784 & -18.08 & -3.35 \\
QW2 & SA & 285125082085302 & Big Jones Creek 7 ft SA well & 20081203 & 1600 & 0.70790 & -16.54 & -3.23 \\
QW3 & UFA & 285035082075401 & Little Jones Creek 48 ft UFA well & 20081202 & 1230 & 0.70783 & -18.1 & -3.36 \\
\hline QW4 & SA & 285035082075402 & Little Jones Creek 11 ft SA well & 20081202 & 1430 & 0.70790 & -17.19 & -3.37 \\
QW5 & UFA & 284811082091301 & (ROMP) LP-3 152 ft UFA well & 20081204 & 1130 & 0.70773 & -7.11 & -1.4 \\
QW6 & UFA & 284628082073801 & (ROMP) LP-4 240 ft UFA well & 20081208 & 1700 & 0.70777 & -12.26 & -2.5 \\
\hline QW7 & UFA & 284628082073802 & (ROMP) LP-4 120 ft UFA well & 20081208 & 1400 & 0.70794 & -21.31 & -3.98 \\
QW8 & SA & 284628082073803 & (ROMP) LP-4 30 ft SA well & 20081204 & 1400 & 0.70795 & -21.26 & -4.16
\end{tabular}


Table 12. Strontium, hydrogen, and oxygen isotope data collected from select groundwater, surface-water, and spring sites in the Lake Panasoffkee study area, July 2007 and December 2008 through January 2009.—Continued

[yyyy/mm/dd, year/month/day; EST, Eastern Standard Time; ft, feet; per mil, parts per thousand; UFA, Upper Floridan aquifer; SA, surficial aquifer; SPG, spring; SW, surface water; LFA, Lower Floridan aquifer]

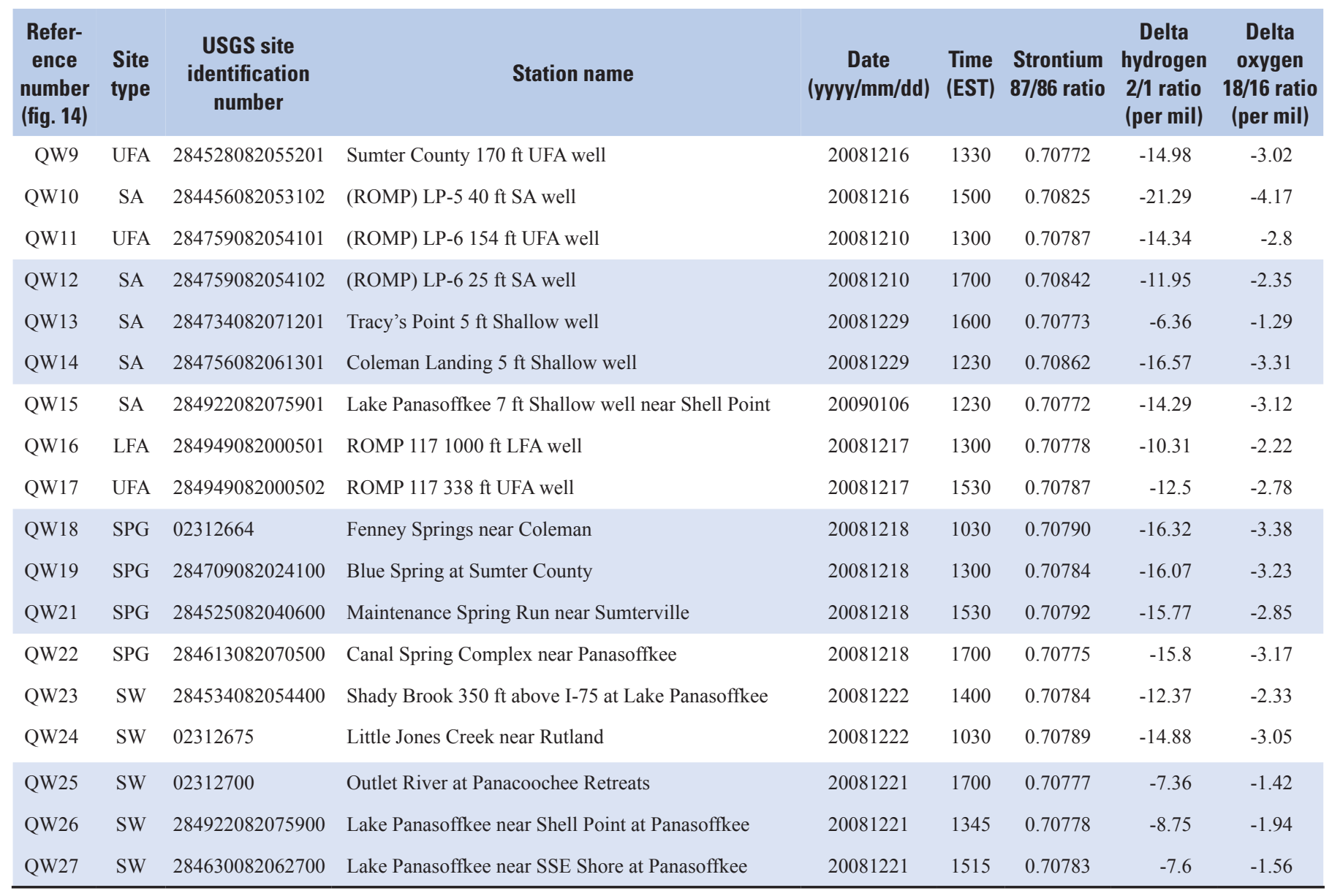

Together with the sulfate data, ${ }^{87} \mathrm{Sr} /{ }^{86} \mathrm{Sr}$ evidence suggests that water upwelling from deep within the Upper Floridan aquifer contributes substantial amounts of groundwater inflow to Lake Panasoffkee, at least during times of drought. The results of the strontium isotope analyses (figs. 35) are consistent with the trilinear plots of major ion data because the water-quality sampling sites with the highest sulfate values generally had the lowest strontium isotope ratios.

There also were geochemical indications of upward leakage from the Ocala Limestone to the surficial aquifer. July 2007 samples from surficial aquifer wells QW10 and QW12 (fig. 14 and table 4) showed evidence of flow from the Ocala Limestone, with ${ }^{87} \mathrm{Sr} /{ }^{86} \mathrm{Sr}$ ratios of 0.70828 and 0.70856 , respectively (fig. 35B). Katz and Bullen (1996) determined that the range of ${ }^{87} \mathrm{Sr} /{ }^{86} \mathrm{Sr}$ ratios in the Ocala Limestone was between 0.7081 and 0.7085 . The Upper Floridan aquifer heads were higher than surficial aquifer heads in July 2007 , and the Ocala Limestone is the uppermost member of the Upper Floridan aquifer at this well site. It is also possible that these samples represent young groundwater that had not yet come into equilibrium with the Ocala Limestone, but upward leakage seems most likely because of the upward head difference in the Upper Floridan aquifer and overall carbonate water quality in the surficial aquifer.

The remainder of the water samples of all types had a narrower range of ${ }^{87} \mathrm{Sr} /{ }^{86} \mathrm{Sr}$ ratios, from 0.70785 to 0.70803 . These ratios fall between those of the Ocala Limestone and the Avon Park Formation, and probably represent mixtures of water from these formations. Many of the Upper Floridan aquifer wells that were sampled have long open intervals that span both formations. Flow from springs also would likely contact both formations, because much of the spring flow in the area has been attributed to conduits that form along the interface between the formations (Miller, 1986). 
Water in wells west of Lake Panasoffkee is probably influenced by water upwelling from deep within the Upper Floridan aquifer near middle confining unit II, whereas the water in wells $7 \mathrm{mi}$ east of Lake Panasoffkee is not. Samples from ROMP 117 (QW16 and QW17), the Lower Floridan aquifer and deep Upper Floridan aquifer wells east of Lake Panasoffkee, had ${ }^{87} \mathrm{Sr} /{ }^{86} \mathrm{Sr}$ ratios slightly higher (younger) than the deep Upper Floridan aquifer wells west of Lake Panasoffkee (QW5, QW6, and QW9) (figs. 14 and 35B, and tables 4 and 12). Despite being finished almost $100 \mathrm{ft}$ deeper in the Upper Floridan aquifer than the deepest Upper Floridan aquifer well west of Lake Panasoffkee, water from ROMP 117 UFA (QW17) had a slightly higher ${ }^{87} \mathrm{Sr} /{ }^{86} \mathrm{Sr}$ ratio than all three of the deep Upper Floridan aquifer wells west of the lake. ROMP 117 LFA (QW16), about $750 \mathrm{ft}$ deeper than the deepest western well and finished in the Lower Floridan aquifer below middle confining unit I, also had a higher ${ }^{87} \mathrm{Sr} /{ }^{86} \mathrm{Sr}$ ratio than two of the western wells (QW5 and QW9) and was similar (but slightly higher in ratio) than the third well (figs. 14 and $35 \mathrm{~B}$, and tables 4 and 12). The higher ${ }^{87} \mathrm{Sr} /{ }^{86} \mathrm{Sr}$ ratio east of Lake Panasoffkee indicates a change in the hydrogeology of the system from west to east, perhaps related to fracturing or faulting. Unfortunately, at the time of this study, there were no wells west of Lake Panasoffkee that penetrated as deep as middle confining unit II or the Lower Floridan aquifer to clarify where this transition in the subsurface occurs. Somewhere beneath Lake Panasoffkee, middle confining unit I thins or is leaky enough that it no longer acts even as a semiconfining unit, because mineralized water associated with deeper formations, likely middle confining unit II, moves upward to the Upper Floridan aquifer.

\section{Deuterium and Oxygen-18}

Deuterium and oxygen isotope ratios in groundwater samples, together with head data from the Upper Floridan and surficial aquifers, indicate that recharge occurs quickly following rainfall in the Lake Panasoffkee watershed, and support the assumption that the watershed is primarily internally drained. The $\delta^{2} \mathrm{H}$ and $\delta^{18} \mathrm{O}$ composition of the majority of the groundwater samples collected in the Lake Panasoffkee watershed during both the July 2007 and December 2008 through January 2009 sampling events plot at or slightly to the right of the intersection of the MWLs and evaporation trend lines (fig. 36). The low level of enrichment in groundwater samples indicates that water recharges quickly in the watershed before much evaporation can occur at land surface. Samples collected from Lake Panasoffkee and the Outlet River were the most enriched of all the $\delta^{2} \mathrm{H}$ and $\delta^{18} \mathrm{O}$ samples collected in the watershed (samples QW25, QW26, QW28, and QW29, fig. 14 and table 4). Groundwater samples that plot at the base of the evaporation trend line are the least enriched (most depleted) in the watershed. Samples that plot along the evaporation trend line contain mixtures of these two end members (enriched water and depleted water).
Samples collected at greater depths within the Upper and Lower Floridan aquifers during both sampling events (fig. 36) also were generally more enriched in $\delta^{2} \mathrm{H}$ and $\delta^{18} \mathrm{O}$ than samples from shallower depths. Enrichment in this situation is related to water age. Water deep within the Floridan aquifer system was recharged thousands of years ago under different climatic conditions than are present today (Plummer and Sprinkle, 2001). During the Last Glacial Maximum (LGM) about 20,000 years ago, water in coastal areas of the southeastern United States were enriched in $\delta^{2} \mathrm{H}$ and $\delta^{18} \mathrm{O}$ as much as $2.3 \%$. The enrichment was most likely caused by the large volume of isotopically light water trapped in glaciers. Continental interiors during the LGM were typically isotopically depleted, because of cooler temperatures. Even though most of the water sampled from the Floridan aquifer system was recharged much more recently than the LGM, these samples likely contain fractions of water that was recharged during the LGM (Plummer and Sprinkle, 2001; L.N. Plummer, U.S. Geological Survey, written commun., 2010).

Samples from sites QW5 and QW27 (figs. 14 and 36A, tables 4 and 12) contain mixtures of water from different sources (groundwater and surface water) because they plot near the middle of the evaporation trend line. Site QW5, a 152-ft deep Upper Floridan aquifer well located near the Outlet River, likely receives recharge from the Outlet River (QW25) because the isotopic content of the sample plots about midway between the MWLs and the sample from Outlet River (figs. 14 and 36A, tables 4 and 12). The sample from site QW27 was collected from Lake Panasoffkee near the confluences of Shady Brook and Warnel Creek (figs. 14 and $36 \mathrm{~A}$, tables 4 and 12). The isotopic composition of the sample likely results from a mixture of enriched lake water and water discharging from the two streams. Water emanating from the two streams primarily originates from spring flow.

The $\delta^{2} \mathrm{H}$ and $\delta^{18} \mathrm{O}$ data from the samples collected in December 2008 through January 2009 (fig. 36B) followed a similar pattern to the July 2007 data (fig. 36A), but there was less variability. The lack of variability was probably because of the time of the year the samples were collected, and the continuing drought at the time of sampling. During winter, there is less evaporation from surface water because of cooler temperatures and shorter days, so surface water is less enriched in $\delta^{2} \mathrm{H}$ and $\delta^{18} \mathrm{O}$. The months preceding the sampling event in December 2008 through January 2009 also had been very dry, so groundwater inflow from the Upper Floridan aquifer was a larger component of the overall lake water budget compared to July 2007, which also contributed to a less enriched $\delta^{2} \mathrm{H}$ and $\delta^{18} \mathrm{O}$ isotopic signature.

Sample QW13 (figs. 14 and 36B, tables 4 and 12), the most isotopically enriched sample during the second sampling event, was collected from a piezometer installed about $5 \mathrm{ft}$ beneath the lakebed along the western shore of Lake Panasoffkee. Enrichment of $\delta^{2} \mathrm{H}$ and $\delta^{18} \mathrm{O}$ indicates that Lake Panasoffkee was recharging the surficial aquifer at this location. The recharge/discharge potential maps (figs. 24 

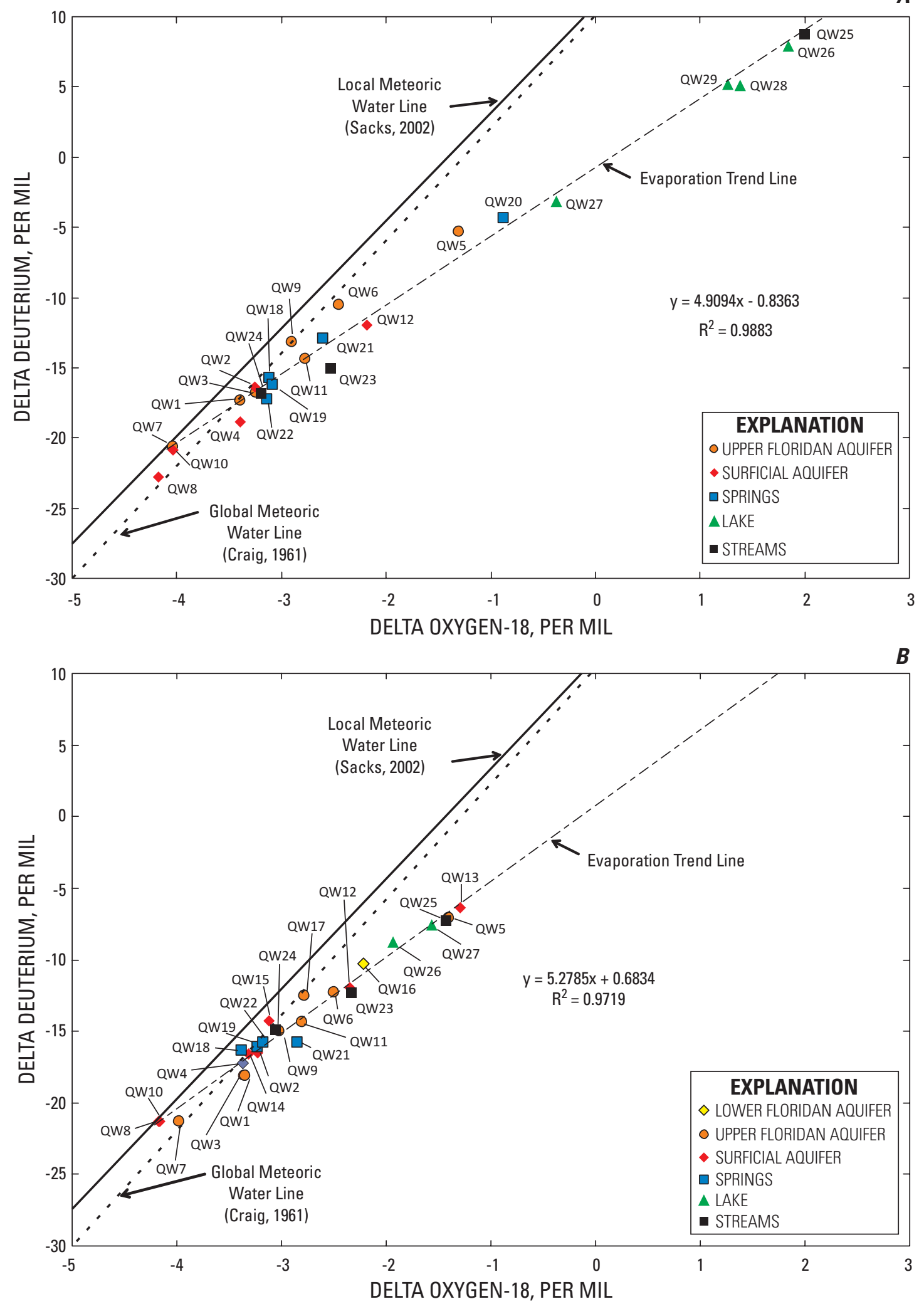

Figure 36. Relation between deuterium and oxygen isotope data in the Lake Panasoffkee study area for $A$, July 2007 and $B$, December 2008 through January 2009. 
and 25) created for the study area indicated that sample QW13 was collected near the boundary of a recharge/discharge area. In contrast, data from sites QW14 and QW15 (fig, 14 and $36 B$, tables 4 and 12), also shallow piezometers, indicated that the lake was receiving groundwater inflow at those locations. QW14 was installed $5 \mathrm{ft}$ beneath the lakebed on the western shore of Lake Panasoffkee, whereas QW15 was installed $7 \mathrm{ft}$ beneath the lakebed about $300 \mathrm{ft}$ from the northeastern shoreline of the lake. These results are consistent with the lake water budget, which indicated that the lake was receiving more groundwater inflow than it was losing in December 2008. The recharge/discharge potential maps created for the study area indicated that the QW14 and QW15 samples were collected in a discharge area.

\section{Age Dating}

Samples from select groundwater and spring sites were analyzed for ${ }^{14} \mathrm{C},{ }^{3} \mathrm{H}, \mathrm{SF}_{6}$, and $\mathrm{CFC}$ concentrations. These four environmental tracers are useful for determining the time that has passed since a parcel of water recharged the groundwater system. Knowledge of the age of a groundwater sample helps determine if mixing is occurring between different aquifers, for determining sources of groundwater, and helps in locating recharge areas (Cook and Böhlke, 2000).

\section{Carbon-14 and Tritium}

Samples from QW6, QW16, and QW17 (fig. 14 and table 4) were analyzed for ${ }^{14} \mathrm{C}$, because they were the deepest wells in the study area and would likely yield water too old to be dated by any other readily available age dating method. Well QW6, located near the western shore of Lake Panasoffkee, penetrates $240 \mathrm{ft}$ below land surface deep into the Upper Floridan aquifer (fig. 37). ROMP 117 wells (QW16 and QW17) are located about $7 \mathrm{mi}$ east of Lake Panasoffkee on the northeast shore of Lake Okahumpka (fig. 37). ROMP 117 UFA (QW17) penetrates $338 \mathrm{ft}$ below land surface to the bottom of the Upper Floridan aquifer and is finished near the top of middle confining unit I. ROMP 117 LFA (QW16) penetrates $1,000 \mathrm{ft}$ below land surface through middle confining unit I and is finished in the upper part of the Lower Floridan aquifer.

Four adjusted ${ }^{14} \mathrm{C}$ ages were calculated within the NETPATH model for each water sample using the formulas developed by Ingerson and Pearson (1964), Tamers (1975), Fontes and Garnier (1979), and Eichinger (1983). Groundwater ages can be presented in this report as either an "apparent" age or as an "adjusted" age. Apparent ages are those ages given as part of the analytical results, whereas adjusted ages have been modified from the analytical results using geochemical models to compensate for degradation of the tracer in the hydrologic system. Apparent ages are typically used when no proof of degradation is evident. The adjusted ${ }^{14} \mathrm{C}$ ages from the NETPATH model ranged from 7,022 to 7,579 years before present for the water samples from ROMP 117 UFA (QW17), from 8,703 years to 9,413 years before present for ROMP 117 LFA (QW16), and from 23,485 to 26,455 years before present for ROMP LP-4 UFA (QW6) (fig. 14 and tables 4 and 13). All of the calculated ages are considered maximum ages because recrystallization of carbonates was not considered in any of the model formulas. Only the water sample from ROMP LP -4 UFA (QW6) showed substantial signs of recrystallization, which for carbonates, makes a sample appear older than it actually is. The ROMP LP-4 UFA (QW6) sample could be several thousand years younger than was calculated by the models.

Water samples from QW6, QW16, and QW17 also were analyzed for ${ }^{3} \mathrm{H}$ to determine if a mixture of both young (recharged post-1952) and old groundwater (recharged pre-1952) was present in the samples (fig. 14, tables 4 and 13). ${ }^{3} \mathrm{H}$ was detected in all of the samples, but all results were near the method detection limit of 0.09 TU. QW6 had the highest detection at $0.31 \mathrm{TU}$, whereas QW16 and QW17 had detections of 0.14 and $0.12 \mathrm{TU}$, respectively. Because naturally occurring "pre-hydrogen bomb" background concentrations of ${ }^{3} \mathrm{H}$ have been estimated at 5-10 TU, groundwater with concentrations less than about $1 \mathrm{TU}$ are considered older than 1952 (Clark and Fritz, 1997). The detected ${ }^{3} \mathrm{H}$ levels were sufficiently low in all three water samples that mixing of young and old groundwater can be considered insignificant in these samples.

The similarity in radiocarbon age of samples from QW16 and QW17 (fig. 14, tables 4 and 13) indicates that middle confining unit I is leaky east of Lake Panasoffkee. The similarities in radiocarbon ages and in major ion chemistries at these sites indicate exchange of water between the Upper Floridan aquifer and Lower Floridan aquifer in this area. The ${ }^{14} \mathrm{C}$ water sample collected at QW6 (fig. 14, tables 4 and 13) is older than the samples collected at QW16 and QW17, even though both of these wells are much deeper than QW6. The increase in age of the groundwater west of Lake Panasoffkee at shallower depths in the Upper Floridan aquifer is further evidence of water upwelling from deep within the Floridan aquifer system west of Lake Panasoffkee. The ${ }^{14} \mathrm{C}$ age data, together with the sulfate data presented earlier, indicate that the upwelling water probably contacts middle confining unit II somewhere along its flow path. Middle confining unit II is the only formation in the study area known to contain enough gypsum to explain the sulfate concentrations found in the sample, and the age of the sample indicates a deep flow source.

\section{Sulfur Hexafluoride}

A piston flow model was used to derive the $\mathrm{SF}_{6}$ ages presented in this report; it is assumed in the model that a parcel of water is recharged to an aquifer and travels through the aquifer to a point of discharge while remaining unaltered by transport processes along the way (Busenberg and Plummer, 2000). It is unlikely, however, that piston flow is maintained in the karst topography of the study area 


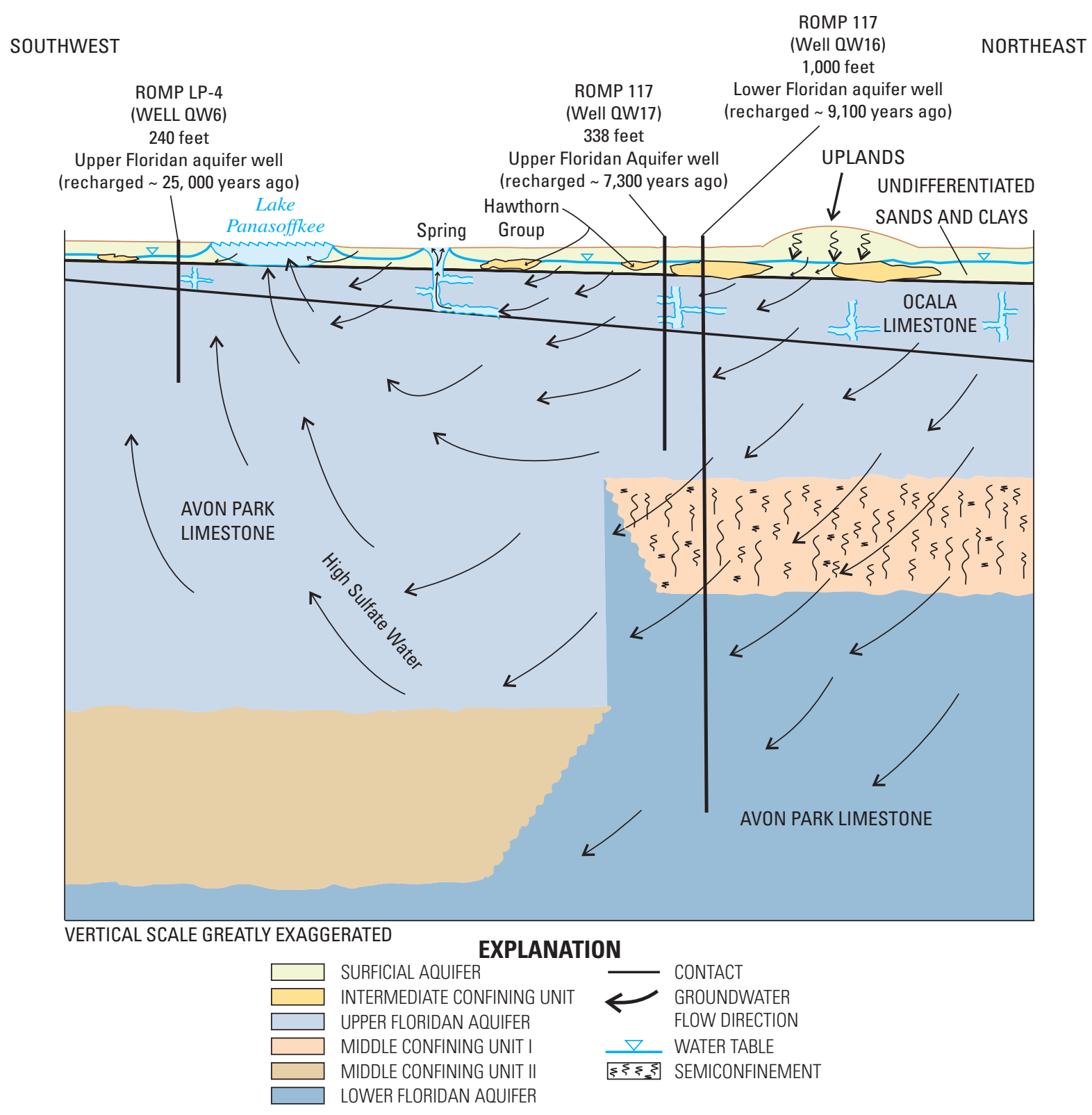

Figure 37. Generalized conceptual model of the Lake Panasoffkee watershed based on geochemical analyses. Figure 14 and table 4 show well locations and specifications.

because of potential "short circuits" in unconfined karst areas where flow enters the system midway along the flow path. The apparent age of the water likely reflects a mixture of waters recharged to the groundwater system at different points in time. The $\mathrm{SF}_{6}$ ages presented here are therefore averages of the mixtures of groundwaters collected in a sample.

Eleven surficial aquifer and Upper Floridan aquifer wells were sampled for $\mathrm{SF}_{6}$ and dissolved gases (table 14). Except for wells QW6, QW15, and QW17 (fig. 14 and table 4), all of the wells sampled for $\mathrm{SF}_{6}$ have a component of young groundwater that has recharged the groundwater system within the last 35 years, which is the effective dating range of $\mathrm{SF}_{6}$
(Busenberg and Plummer, 2000). The water sample from well QW15 did not contain detectable levels of $\mathrm{SF}_{6}$, and samples from wells QW6 and QW17 both contained $0.1 \mathrm{fMol} / \mathrm{L}$ of $\mathrm{SF}_{6}$, which is just above the analytical detection limit for $\mathrm{SF}_{6}$. One $\mathrm{fMol} / \mathrm{L}$ is equal to $10^{-15}$ moles in 1 liter of water. None of the samples from these three wells contained enough $\mathrm{SF}_{6}$ to accurately determine an age of recharge; however, all can be considered free of young water recharged in the last 35 years. Excluding surficial aquifer well QW15, mean modeled recharge years for the water samples from the surficial aquifer wells ranged from 1989 to 2001 . Water samples from the two Upper Floridan aquifer wells $154 \mathrm{ft}$ deep or less had mean 


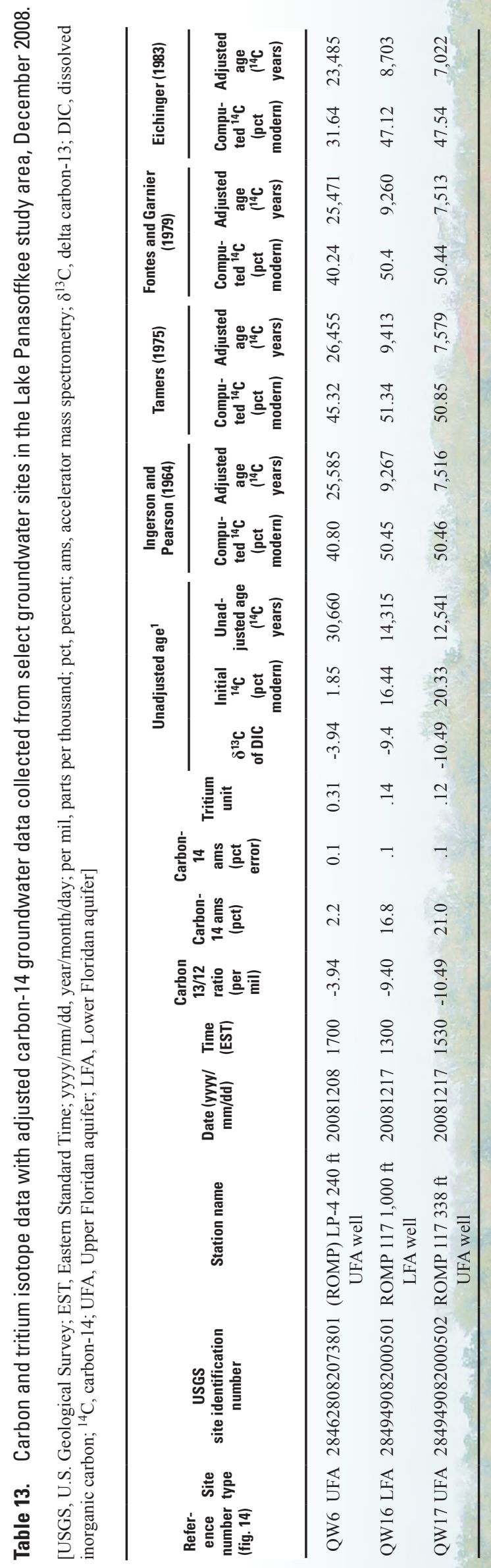

My) Water Chemistry 75

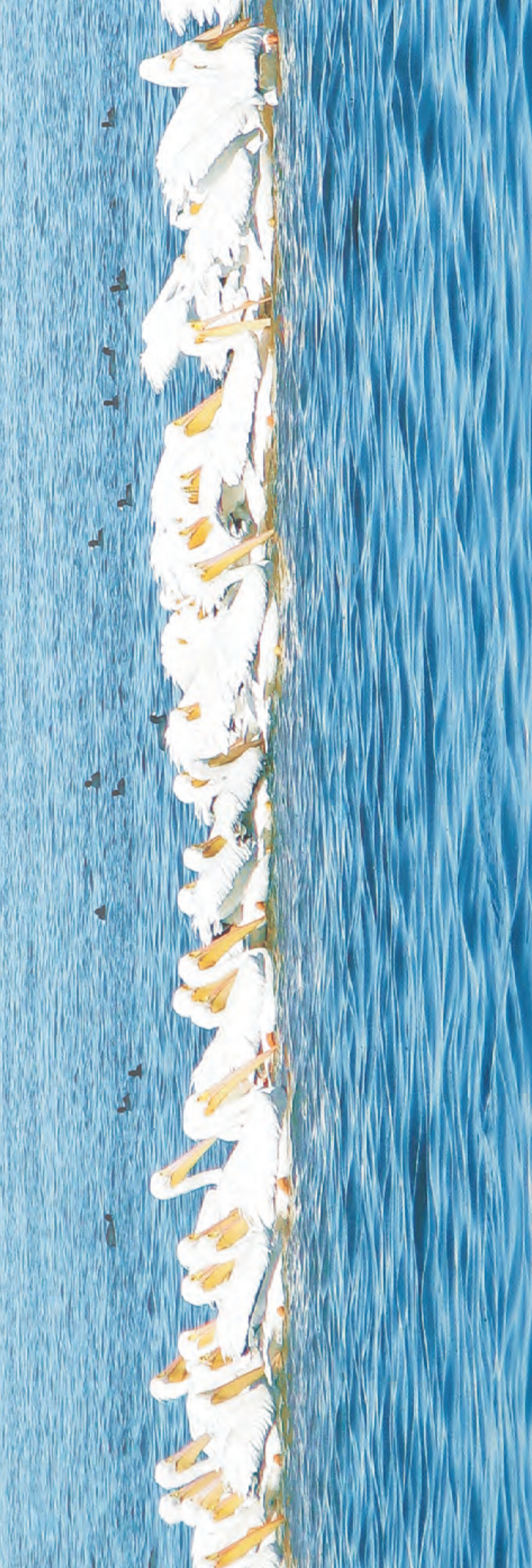




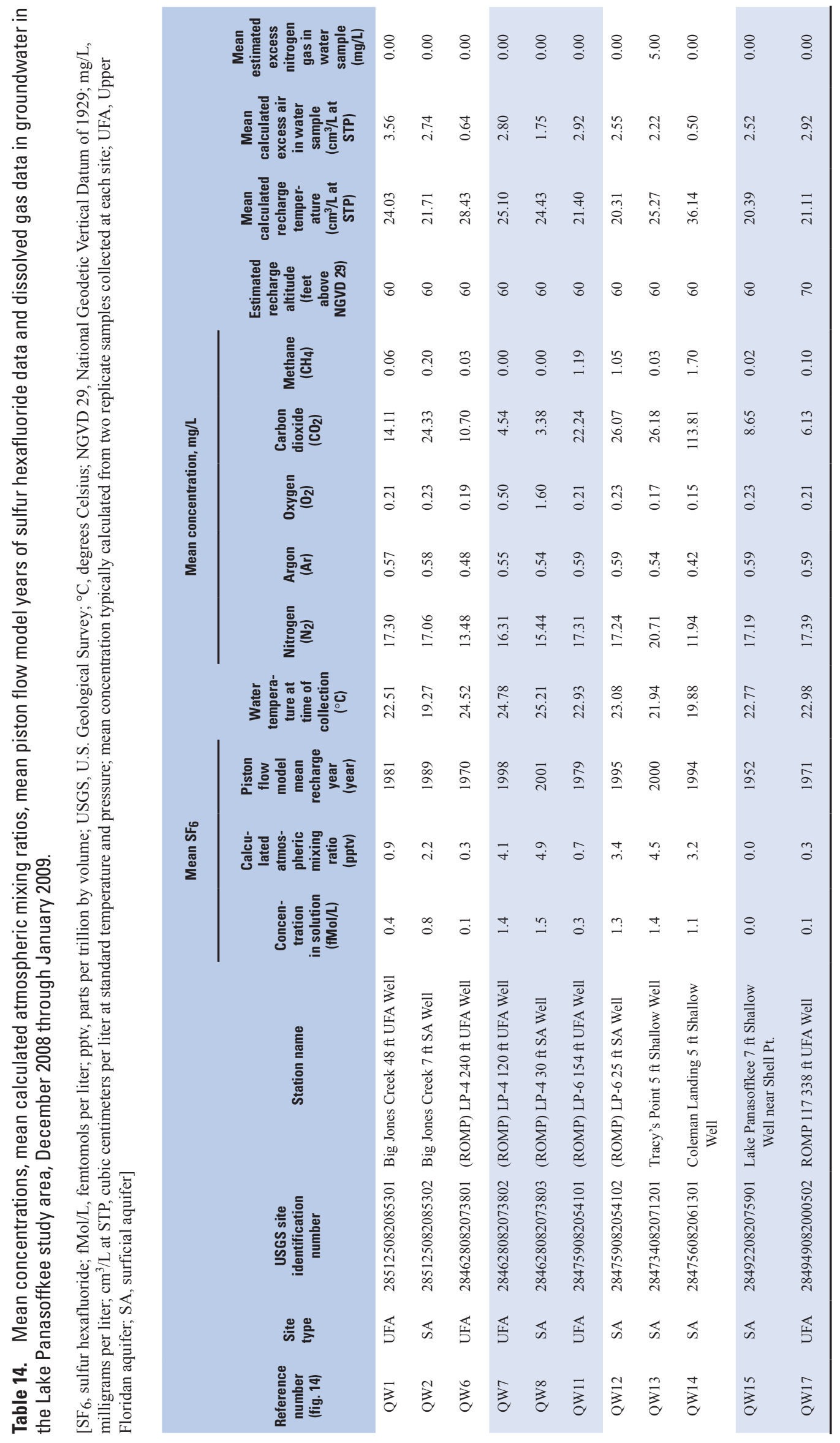


modeled recharge years ranging from 1979 to 1998 . None of the Upper Floridan aquifer wells that were sampled at greater than $240 \mathrm{ft}$ below land surface contained enough $\mathrm{SF}_{6}$ to model an accurate age of recharge and, using the aforementioned reasoning, can be considered free of modern water recharged to the Upper Floridan aquifer in the last 35 years.

Water from two of the three shallow drivepoint piezometers (QW13 and QW14) that were installed in the surficial aquifer beneath Lake Panasoffkee had apparent recharge years of 2000 and 1994, respectively, based on $\mathrm{SF}_{6}$ concentrations. Water from the third well (QW15) was recharged prior to 1973 (fig. 14 and tables 4 and 14). The older recharge date from QW14 is probably an indication of greater groundwater inflow at that site than the other sites. An increase in the volume of water upwelling from the Upper Floridan aquifer into the surficial aquifer would result in an older apparent date of recharge. The sample from well QW15 was the only groundwater sample analyzed for $\mathrm{SF}_{6}$ that had no measurable $\mathrm{SF}_{6}$ concentration. Although it is possible that the $\mathrm{SF}_{6}$ was degraded by the geochemical conditions beneath the lake, $\mathrm{SF}_{6}$ is typically resistant to change under highly reducing conditions and from biodegradation (Busenberg and Plummer, 2000). The water sample from well QW15 appears to be composed entirely of water greater than 35 years in age.

Three of the well nests sampled for $\mathrm{SF}_{6}$ included at least one surficial aquifer well and one Upper Floridan aquifer well. All of the nested well samples indicated an older apparent age in the Upper Floridan aquifer compared to water from the surficial aquifer. QW1 and QW2, the nested wells northeast of Lake Panasoffkee at Big Jones Creek, had apparent recharge years of 1981 and 1989, respectively (fig. 14 and tables 4 and 14). QW6, QW7, and QW8, which are all part of the ROMP LP-4 well nest west of Lake Panasoffkee, had apparent recharge years of 1970, 1998, and 2001 for the deep Upper Floridan aquifer, shallow Upper Floridan aquifer, and surficial aquifer wells, respectively (fig. 14 and tables 4 and 14). Samples from QW11 and QW12, located near the eastern shore of Lake Panasoffkee, had apparent recharge years of 1979 and 1995, respectively (fig. 14 and tables 4 and 14). Despite descriptions of a thin intermediate confining unit in drillers' logs for many of these wells, the presence of $\mathrm{SF}_{6}$ below the confining unit confirms that the intermediate confining unit is leaky or discontinuous throughout much of the study area.

Throughout the study area, the calculated years of recharge tended to be older than anticipated for shallow surficial aquifer wells. However, these surficial aquifer samples were collected during a time of drought when heads in the Upper Floridan aquifer were higher than those in the surficial aquifer over much of the study area. During a period of wetter weather when the Upper Floridan aquifer is being recharged by the surficial aquifer, water samples from the surficial aquifer would likely date younger than during dry periods.

None of the analyses of CFCs in water samples were valid because of environmental degradation that reduces CFC concentrations after recharge to the groundwater system.
Several environmental processes are known to degrade CFCs. Unfortunately, all but two of the 11 surficial aquifer and Upper Floridan aquifer well-water samples were degraded under reducing conditions (indicated by the presence of methane), rendering the data unreliable. This degradation typically occurs when methane-producing bacteria biodegrade CFCs at the groundwater/surface-water interface under anoxic conditions (Happell and others, 2003).

\section{Summary}

Lake Panasoffkee is a 5,700-acre water body located in west-central Florida on the western border of Sumter County. The study area includes Lake Panasoffkee and the surrounding watershed.

The uppermost part of the groundwater system in the Lake Panasoffkee watershed consists of a thin, unconfined surficial aquifer composed primarily of sand. Discontinuous clays and sands of the Hawthorn Group compose the intermediate confining unit, which separates the surficial aquifer from the Upper Floridan aquifer within the study area. The Upper Floridan aquifer in this area consists of the Ocala Limestone and the upper part of the Avon Park Formation. In west-central Florida, the Upper Floridan aquifer is separated from the Lower Floridan aquifer by either middle confining unit I, middle confining unit II, or both in areas where the units overlap. Middle confining unit I lies primarily east of Lake Panasoffkee, whereas middle confining unit II lies mostly west of Lake Panasoffkee. Middle confining unit I is typically more leaky than middle confining unit II.

Lake Panasoffkee exhibits a strong hydraulic connection with the underlying Floridan aquifer system. Examination of hydrologic data indicates there is potential for exchange of water between the surface-water and groundwater systems. Differences in water level from paired surficial and Upper Floridan aquifer wells indicate that recharge conditions were present during the study period northeast and southeast of Lake Panasoffkee in the nearby uplands, whereas discharge conditions were present around Lake Panasoffkee and in adjacent areas southeast and northwest of the lake.

The recharge areas coincide with lands of high surface elevation, such as the ridges of the Sumter and Lake Uplands. Precipitation rapidly infiltrates the sandy uplands and recharges the surficial aquifer. The lack of a continuous intermediate confining unit in much of the study area allows water from the surficial aquifer to freely recharge the limestone of the Upper Floridan aquifer, and even where the intermediate confining unit is present, recharge can still quickly reach (in days or hours) the Upper Floridan aquifer because of the karst features in the area. Sinkholes, fissures, and conduits are all parts of an internal drainage system that breaches the intermediate confining unit and allows surface water to recharge directly into the Upper Floridan aquifer. 
Piezometers driven into the bed of Lake Panasoffkee generally indicated an upward head difference between the surficial aquifer and the lake during synoptic measurements. Upward head differences between the Upper Floridan aquifer and the surficial aquifer indicate the potential for water to discharge from the Upper Floridan aquifer into the overlying surficial aquifer. Similarly, groundwater discharges into surface-water bodies through porous bed materials when hydraulic head in the Upper Floridan aquifer is higher than surface-water levels.

A drought that extended from 2005 through the end of data-collection activities in September 2008 resulted in below-normal groundwater levels for most of the study period. During the study period, wetter conditions resulted in more intense recharge in the recharge areas and more intense discharge in the discharge areas. The spatial relation between groundwater recharge and discharge areas remained relatively constant throughout the study period.

Monthly water-budget calculations were used to determine groundwater-inflow rates. Based on rainfall data collected at three stations within the Lake Panasoffkee watershed, rainfall totaled $91.71 \mathrm{in}$. between October 2006 and September 2008 (water years 2006-8). For the 1930-2008 water years, annual average precipitation for the area is 54.26 in. Five surface-water gaging stations were used to determine the monthly volume of surface-water inflow and outflow to Lake Panasoffkee, of which Little Jones Creek and Shady Brook were the main contributors. Discharge at Little Jones Creek ranged from $6.56 \mathrm{ft}^{3} / \mathrm{s}$ in June 2007 to $75.8 \mathrm{ft}^{3} / \mathrm{s}$ in August 2008, whereas flows at Shady Brook ranged from $8.28 \mathrm{ft}^{3} / \mathrm{s}$ in June 2007 to $59.6 \mathrm{ft}^{3} / \mathrm{s}$ in September 2008 .

Discharge from Lake Panasoffkee to Outlet River ranged from a low of $12.6 \mathrm{ft}^{3} / \mathrm{s}$ in June 2007 to a high of $225 \mathrm{ft}^{3} / \mathrm{s}$ in August 2008. During water years 2007 and 2008, a combined total of 90.50 in. of water evaporated from Lake Panasoffkee, or 45.96 and $44.54 \mathrm{in} / \mathrm{yr}$, respectively. Lake Panasoffkee evaporation rates were about 17 to 28 percent lower than those measured at other lakes in central Florida. Most of the difference in evaporation rates can be attributed to lower net radiation measured at Lake Panasoffkee. Lower net radiation is assumed to be the result of greater reflectance of solar radiation (albedo) caused by the naturally occurring and lightly colored carbonate sediments that compose the lakebed and that are easily suspended in the shallow water column during windy periods. This increased reflectance may have been exacerbated during the study period by the ongoing lake-restoration work.

Water-budget calculations indicate that Lake Panasoffkee gained substantial water from groundwater inflows during the study period. Monthly groundwater inflows as a percentage of total inflows during the 2-year data-collection period ranged from 11 percent in October 2007 to 50 percent in May 2007, with a total contribution of 29 percent of all inflow over the 2 -year data-collection period. Comparatively, the total volume of surface-water inflow for the 2-year data-collection period was 50 percent of total inflow, and rainfall accounted for 21 percent. The percentage of groundwater inflow received by
Lake Panasoffkee is not unusual compared to other central Florida lakes, but the source and the volume of groundwater inflow are atypical. A previous USGS study of groundwater inflow to 81 lakes in central Florida rated each lake as a "low," medium," or "high" groundwater inflow lake. Lake Panasoffkee falls in the medium category of lakes because it received an average of 29 percent of its total inflow from groundwater during the 2-year data-collection period. What is unusual is that the primary source of groundwater inflow to Lake Panasoffkee is the Upper Floridan aquifer. All of the lakes in the previous study received their groundwater inflow from the surficial aquifer. The total volume of groundwater inflow received by Lake Panasoffkee also differs from other lakes. Calculations indicate that Lake Panasoffkee received $1.38 \mathrm{billion}^{3} / \mathrm{yr}$ of groundwater inflow during water year 2008. The largest (5,074 acres) of the 81 lakes in the previous USGS study received only 294 million $\mathrm{ft}^{3} / \mathrm{yr}$. Lake Panasoffkee also receives much of its surface-water inflow from groundwater, because as much as 78 percent of the surface-water inflow originated as spring discharge during the study period.

Two sets of water samples were collected from Lake Panasoffkee, its tributaries, and selected groundwater and spring sites in July 2007 and December 2008 through January 2009. Trilinear diagrams indicate three distinct water types within the Lake Panasoffkee watershed: calcium-bicarbonate type waters, mixed calcium-bicarbonate/calcium-sulfate type waters, and two groundwater samples (from the same well) that were composed of calcium-sulfate type water. The presence of calcium-bicarbonate and calcium-sulfate type waters in the surficial aquifer, spring, and lake water samples indicates that the Upper Floridan aquifer contributes inflow to the overlying hydrogeologic units and surface-water bodies in the Lake Panasoffkee watershed.

Sulfate concentrations in west-central Florida are typically low (less than $30 \mathrm{mg} / \mathrm{L}$ ) in surface waters, the surficial aquifer, and the shallow parts of the Upper Floridan aquifer. Water samples collected from Lake Panasoffkee in July 2007 exceeded $30 \mathrm{mg} / \mathrm{L}$. A previous USGS study of the Lake Panasoffkee area concluded that the most likely source of the high sulfate waters in and around Lake Panasoffkee was water upwelling from near the base of the Upper Floridan aquifer. This upwelling suggests that there is a mechanism that allows water to move from the Avon Park Formation deep in the Upper Floridan aquifer to the shallow Upper Floridan and surficial aquifers. Vertical groundwater flow in the area is likely related to fractures and faults associated with the Ocala structural high. Physiographic expressions at land surface, including the shape of Lake Panasoffkee, indicate that one or more faults may be present in the Lake Panasoffkee area, although no physical evidence has been found to date.

Water samples collected in July 2007 and December 2008 through January 2009 were analyzed for the isotopic ratios of strontium, oxygen, and hydrogen. Strontium isotope ratios were higher in samples from both of the main surface-water tributaries to Lake Panasoffkee and in all of 
the springs, suggesting that the lake receives groundwater inflow that originates in hydrogeologic units that are geologically older than the surficial aquifer or shallow parts of the Upper Floridan aquifer (Ocala Limestone). The strontium isotope data indicate that Lake Panasoffkee receives water that originates deep in the Upper Floridan aquifer in the Avon Park Formation. Strontium isotope ratios found in samples from Lake Panasoffkee were similar to samples taken from Upper Floridan aquifer wells finished in the Avon Park Formation south and southwest of Lake Panasoffkee.

Hydrogen and oxygen isotopic ratios $\left(\delta^{2} \mathrm{H}\right.$ and $\left.\delta^{18} \mathrm{O}\right)$ indicate that rainfall rapidly recharges the groundwater system in the Lake Panasoffkee watershed. The isotope data collected in July 2007 and December 2008 through January 2009 mostly plot near the LMWL, indicating a lack of enrichment and, therefore, that rainfall infiltrates the groundwater system rapidly near Lake Panasoffkee. This result is consistent with the assumption that water is internally drained in the watershed. Samples collected from Lake Panasoffkee and its tributaries showed the most isotopic enrichment, as might be expected of surface water that has undergone evaporation. Two $\delta^{2} \mathrm{H}$ and $\delta^{18} \mathrm{O}$ samples collected in December 2008 from the surficial aquifer beneath Lake Panasoffkee, one near the northeast shoreline and one near the east-central shoreline, indicated that the lake was receiving groundwater inflow in those areas. This result is consistent with the Lake Panasoffkee water budget, which indicates that the lake was receiving water through groundwater inflow. The recharge/discharge potential map created for the study area indicates that both these samples were collected in discharge areas. A third surficial aquifer sample from beneath Lake Panasoffkee, collected near the west-central shoreline, indicated the presence of lake water in the surficial aquifer in the vicinity of that well. The recharge/discharge potential map for September 2008 indicates that this sample was collected from a well located near the boundary of a recharge/discharge area.

In December 2008, water samples were collected for analysis of ${ }^{14} \mathrm{C}$ and ${ }^{3} \mathrm{H}$ from the three deepest $(240,338$, and 1,000 ft deep) monitoring wells in the study area. These wells included an Upper and Lower Floridan aquifer well east of Lake Panasoffkee and an Upper Floridan aquifer well west of Lake Panasoffkee. The shallower well east of Lake Panasoffkee is finished above middle confining unit I deep in the Upper Floridan aquifer, whereas the Lower Floridan aquifer well is finished below middle confining unit I. The Upper Floridan aquifer well west of Lake Panasoffkee is finished above middle confining unit II.
After the analyses of the ${ }^{14} \mathrm{C}$ samples was completed, the apparent ${ }^{14} \mathrm{C}$ ages were adjusted using a geochemical mass-balance model to correct the apparent ages for error caused by geochemical changes that result in samples because of contact with aquifer materials. The water sample from the eastern Upper Floridan aquifer well recharged from about 7,022 to 7,579 years before present, whereas the sample from the eastern Lower Floridan aquifer well recharged from about 8,703 to 9,413 years before present. The adjusted age since recharge for the sample from the western Upper Floridan aquifer well ranged from about 23,485 to 26,455 years before present. None of the sample ages were corrected for recrystallization of carbonates, but only the western well showed any indication of recrystallization. The western well sample is probably dated several thousand years too old because of recrystallization of carbonates. The ${ }^{3} \mathrm{H}$ data indicate that none of the three well water samples include a substantial volume of "young" groundwater recharged since 1952.

The similarities in both the radiocarbon age of the water and the major ion chemistry of the samples indicate that water exchanges occur between the Upper and Lower Floridan aquifers in the vicinity of the wells east of Lake Panasoffkee. Despite the Lower Floridan aquifer well on the east side of Lake Panasoffkee being much deeper than the Upper Floridan aquifer well on that side of the lake $(1,000$ and $338 \mathrm{ft}$, respectively), the modeled radiocarbon age of the deep sample was only about 1,500 years older. This small age difference is an indication that middle confining unit I is leaky east of the study area.

In a small, poorly defined area west/southwest of Lake Panasoffkee, water upwells from deep parts of the Upper Floridan aquifer to shallower parts of the Upper Floridan aquifer. Despite both the Upper and Lower Floridan aquifer wells east of Lake Panasoffkee being deeper than the Upper Floridan aquifer well west of the lake, the radiocarbon sample from the well to the west was much older. The difference in the age of the groundwater east and west of Lake Panasoffkee indicates that the upwelling water west/southwest of Lake Panasoffkee does not gain its chemical signature from middle confining unit I or from the Lower Floridan aquifer below middle confining unit I. The upwelling water probably comes in contact with middle confining unit II somewhere along its flow path. Middle confining unit II is the only hydrogeologic unit in the study area that contains sufficient quantities of gypsum to explain the sulfate concentration $(1,700 \mathrm{mg} / \mathrm{L})$ found in the sample from west of Lake Panasoffkee. 


\section{Acknowledgments}

The authors thank the citizens of the Lake Panasoffkee community and surrounding area who granted access to their private properties. Without their cooperation this study would not have been possible. Special thanks are offered to Tracy's Point Fishing Lodge for use of their boat ramp and Mr. and Mrs. Bill Pfettscher for use of their property as a staging area for the installation of hydrologic equipment on Lake Panasoffkee.

Numerous individuals from the Southwest Florida Water Management District provided support for this study, including Ron Basso, Jerry Mallams, Jason LaRoche, Angel Martin, Tamera McBride, Jim Clayton, Dave DeWitt, and Roberta Starks.

Thanks also are offered to U.S. Geological Survey staff who provided technical assistance with this study, including Brian Katz, Niel Plummer, Arturo Torres, Terrie Lee, Patty Metz, Tyler Coplen, Dann Yobbi, Lari Knochenmus, Tom Lopes, John Trommer, Jim Flocks, Dana Wiese, Pete Swarzenski, Chris Reich, Robert Renken, Gary Mahon, and the Data Sections in Orlando and Tampa. Ryan Hollins deserves special recognition for working long days in the field assisting with data collection.

\section{References Cited}

Adams, Alison, 1985, Groundwater supplement to the Wysong-Panasoffkee study: Brooksville, Southwest Florida Water Management District report, $173 \mathrm{p}$.

Allander, K.K., Smith, J.L., and Johnson, M.J., 2009, Evapotranspiration from the lower Walker River Basin, westcentral Nevada, water years 2005-07: U.S. Geological Survey Scientific Investigations Report 2009-5079, 62 p.

Anderson, E.R., 1954, Energy-budget studies, in Water-loss investigations, Lake Hefner studies, technical report: U.S. Geological Survey Professional Paper 269, p. 71-119.

Arthur, J.A., Lee, R.A., and Li, L., 2001, Lithostratigraphic and hydrostratigraphic cross sections through Levy-Marion to Pasco Counties, Southwest Florida: Tallahasssee, Florida Geological Survey Open-File Report 81, 21 p., 10 pls.

Aucott, W.R., 1988, Areal variation in recharge to and discharge from the Floridan aquifer system in Florida: U.S. Geological Survey Water-Resources Investigations Report 92-4086, $92 \mathrm{p}$.
Bays, J.S., and Crisman, T.L., 1981, Results of the Lake Panasoffkee water quality evaluation project, 1980-1981. Final Report: Gainesville, University of Florida Department of Environmental Engineering Sciences, 32 p.

Belanger, T.V., Heck, H.H., Sohn, Mary, Sweets, P.R., Morris, M.A., Julien, Neal, 1993, Sediment mapping and analysis in Crystal River/King's Bay and Lake Panasoffkee: Consultants report for the Southwest Florida Water Management District, 228 p.

Belanger, T.V., Heck, H.H., Sohn, Mary, Sweets, P.R., Morris, M.A., Julien, Neal, 1995, The use of selected sediment analyses to answer lake management questions: A case study for Lake Panasoffkee, Florida: Chemistry and Ecology, v. 11, p. 229-254.

Brenner, Mark, Hodell, D.A., Curtis, J.H., Kenney, W.F., Gu, B., and Leyden, B.W., 2006, Mechanisms for organic matter and phosphorous burial in sediments of a shallow, subtropical, macrophyte-dominated lake: Journal of Paleolimnology, v. 35 , no. 1 , p. $129-148$.

Busenberg, Eurybiades, and Plummer, L.N., 2000, Dating young groundwater with sulfur hexafluoride: Natural and anthropogenic sources of sulfur hexafluoride: Water Resources Research, v. 36, no. 10, p. 3011-3030.

Bush, P.W., and Johnston, R.A., 1988, Ground-water hydraulics, regional flow, and ground-water development of the Floridan aquifer system in Florida and in parts of Georgia, South Carolina, and Alabama: U.S. Geological Survey Professional Paper 1403-C, 80 p.

Buto, S.G., and Jorgensen, B.E., 2007, Geospatial database of ground-water altitude and depth-to-ground-water data for Utah, 1971-2000: U.S. Geological Survey Data Series 302, $10 \mathrm{p}$.

Camp, S.C., and Barcelo, M.D., 1988, Wysong-Panasoffkee ground-water/surface-water project: Brooksville, Southwest Florida Water Management District report, 112 p.

Campbell, K.M., 1989, Geology of Sumter County, Florida: Florida Geological Survey Report of Investigation no. 98, $28 \mathrm{p}$.

CH2M Hill, Inc., 1995, Lake Panasoffkee water and nutrient budget study final report: Consultant's report for Southwest Florida Water Management District, 102 p.

Champion, K.M., and Starks, Roberta, 2001, The hydrology and water quality of springs in west-central Florida: Brooksville, Southwest Florida Water Management District, 148 p. 
Clark, I., and Fritz, P., 1997, Identifying and dating modern groundwaters, chap. 7 of Environmental isotopes in hydrogeology: Boca Raton, Florida, Lewis Publishers, p. 171-196.

Cook, P.G., and Böhlke, J.K., 2000, Determining timescales for groundwater flow and solute transport, chap. 1 of Cook, P.G. and Herczeg, A.L., eds., Environmental tracers in subsurface hydrology: Boston, Kluwer Academic Publishers, p. $1-30$.

Craig, Harmon, 1961, Isotopic variations in natural waters: Science, v. 133, p. 1702-1703.

DePaolo, D.J., and Ingram, B.L., 1985, High-resolution stratigraphy with strontium isotopes: Science, v. 227, no. 4689, p. 938-941.

Eichinger, L., 1983, A contribution to the interpretation of ${ }^{14} \mathrm{C}$ groundwater ages considering the example of a partially confined sandstone aquifer: Radiocarbon, v. 25, p. 347-356.

Elliot, Meghan, Jones, Gregg, and DeWitt, David, 1998, Reconnaissance of springs in the Lake Panasoffkee basin and occurrence of nutrients in the Upper Floridan aquifer: Brooksville, Southwest Florida Water Management District report, $62 \mathrm{p}$.

Environmental Systems Research Institute, Inc., 2006, ArcInfo ${ }^{\circledR}$ 9.2, GIS software user's manual: Redlands, Calif., Environmental Systems Research Institute, Inc.: Accessed online August 2009 at http://webhelp.esri.com/ arcgisdesktop/9.2\%.

Environmental Systems Research Institute, Inc., 2009, ArcGIS Desktop 9.3 Help, "How Spline Works": Accessed online June 15, 2009, at http://webhelp.esri.com/arcgisdesktop/9.3/ index.cfm?topicname $=h o w \_s p l i n e \_w o r k s$.

Faulkner, G.L., 1973, Geohydrology of the Cross-Florida Barge Canal with special reference to the Ocala vicinity: U.S. Geological Survey Water-Resources Investigations Report 1-73, 117 p.

Federal Geographic Data Committee, 1998, Geospatial positioning accuracy standards, Part 3: National standard for spatial data accuracy, Federal Geographic Data Committee, U.S. Geological Survey: Accessed online Jan. 7, 2009, at www.fgdc.gov/standards/docu-ments/standards/accuracy/ chapter3.pdf.

Florida Department of Environmental Protection, 2009, Outstanding Florida waters: Accessed online July 1, 2009, at http://www.dep.state.fl.us/water/wqssp/ofw.htm.
Fontes, J.C., and Garnier, J.M., 1979, Determination of the initial ${ }^{14} \mathrm{C}$ activity of the total dissolved carbon: A review of the existing models and a new approach: Water Resources Research, v. 15, no. 2, p. 399-413.

Gesch, D.B., 2007, The national elevation dataset, in Maune, D., ed., Digital elevation model technologies and applications: The DEM users manual ( $2 \mathrm{~d}$ ed.): Bethesda, Md., American Society for Photogrammetry and Remote Sensing, p. 99-118.

Gesch, D., Oimoen, M., Greenlee, S., Nelson, C., Steuck, M., and Tyler, D., 2002, The national elevation dataset: Photogrammetric engineering and remote sensing, v. 68 , no. 1 , p. $5-11$.

Greiner Engineering Sciences, 1978, Wysong-Lake Panasoffkee resource management study: Southwest Florida Water Management District, Withlacoochee River Basin Board, $26 \mathrm{p}$.

Griffith, G.E., Canfield, D.E., Jr., Horsburgh, C.A., Omernik, J.M., 1997, Lake regions of Florida: U.S. Environmental Protection Agency, Western Ecology Division, R-97/127, $89 \mathrm{p}$.

Happell, J.D., Price, R.M., Top, Z., Swart, P.K., 2003, Evidence for the removal of CFC-11, CFC-12, and CFC-113 at the groundwater-surface water interface in the Everglades: Journal of Hydrology, v. 279, issues 1-4, p. 94-105.

Harrison, A.S., Dadisman, S.V., McBride, W.S., and Wiese, D.S., 2009, Archive of digital boomer and CHIRP seismic reflection data collected during USGS field activity 08LCA03 in Lake Panasoffkee, Florida, May 2008: U.S. Geological Survey Data Series 420, CD-ROM (1 disc), also available online at $h t t p: / / p u b s . u s g s . g o v / d s / 420 /$.

Healy, R.W., Winter, T.C., LaBaugh, J.W., and Franke, O.L., 2007, Water budgets: Foundations for effective waterresources and environmental management: U.S. Geological Survey Circular 1308, 85 p.

Hem, J.D., 1992, Study and interpretation of the chemical characteristics of natural water: U.S. Geological Survey Water-Supply Paper 2254, $263 \mathrm{p}$.

Hortness, J.E., and Vidmar, Peter, 2005, Surface-water/ ground-water interaction along reaches of the Snake River and Henrys Fork, Idaho: U.S. Geological Survey Scientific Investigations Report 2004-5115, 18 p.

Ingerson, E., and Pearson, F.J., 1964, Estimation of age and rate of motion of groundwater by the ${ }^{14} \mathrm{C}$ method: Recent researches in the fields of atmosphere, hydrosphere, and nuclear geochemistry: Sugawara Festival Volume, Maruzen Co., Tokyo, Japan, p. 263-283. 
Inwood Consulting Engineers, 2006, Sumter County stormwater management services assessment program: Big Prairie, Jumper Creek Canal, and Gant Lake watersheds: Consultant's report for Sumter County and Southwest Florida Water Management District, 546 p.

Jones, G.W., Upchurch, S.B., and Champion, K.M., 1996, Origin of nitrate in ground water discharging from Rainbow Springs, Marion County, Florida: Southwest Florida Water Management District, $155 \mathrm{p}$.

Kalin, R.M., 2000, Radiocarbon dating of groundwater systems, chap. 4 of Cook, P.G., and Herczeg, A.L., eds., Environmental tracers in subsurface hydrology: Boston, Kluwer Academic Publishers, p. 111-144.

Katz, B.G., and Bullen, T.D., 1996, The combined use of ${ }^{87} \mathrm{Sr} /{ }^{86} \mathrm{Sr}$ and carbon and water isotopes to study the hydrochemical interaction between groundwater and lakewater in mantled karst: Geochimica et Cosmochimica Acta, v. 60, no. 24 , p. $5075-5087$.

Kelly, E.M., 1996, A plan for the use and management of the East Lake Panasoffkee property: Brooksville, Southwest Florida Water Management District report, $61 \mathrm{p}$.

Kindinger, Jack, 2002, Lake Belt study area: High-resolution seismic reflection survey, Miami-Dade County, Florida: U.S. Geological Survey Open-File-Report 02-325, 23 p.

Kinnaman, S.L., and Dixon, J.F., 2008, Potentiometric surface of the Upper Floridan aquifer in the St. Johns River Water Management District and vicinity, Florida: September 2007, U.S. Geological Survey Open-File-Report 2008-1085, 1 sheet.

Lake Panasoffkee Restoration Council, 2008, Report to the Legislature: Final report: Brooksville, Southwest Florida Water Management District, $9 \mathrm{p}$.

Landers, M.N., and Ankcorn, P.D., 2008, Methods to evaluate the influence of onsite septic wastewater-treatment systems on baseflow in selected watersheds in Gwinnett County, Georgia, October 2007: U.S. Geological Survey Scientific Investigations Report 2008-5220, 20 p.

Lee, T.M., and Swancar, Amy, 1997, Influence of evaporation, ground water, and uncertainty in the hydrologic budget of Lake Lucerne, a seepage lake in Polk County, Florida: U.S. Geological Survey Water-Supply Paper 2439, 61 p.

Maidment, D.R., ed., 2002, Arc Hydro: GIS for water resources: Redlands, California, ESRI Press, 203 p.
Miller, J.A., 1986, Hydrogeologic framework of the Floridan aquifer system in Florida and in parts of Georgia, Alabama, and South Carolina: U.S. Geological Survey Professional Paper 1403-B, 91 p.

National Climatic Data Center, 2009, Climatography of the United States no. 20: Accessed June 10, 2009, at http://cdo. ncdc.noaa.gov/climatenormals/clim20/fl/

Oberg, K.A., Morlock, S.E., and Caldwell, W.S., 2005, Quality-assurance plan for discharge measurements using acoustic Doppler current profilers: U.S. Geological Survey Scientific Investigations Report 2005-5183, 35 p.

O’Reilly, A.M., Spechler, R.M., and McGurk, B.E., 2002, Hydrogeology and water-quality characteristics of the Lower Floridan aquifer in east-central Florida: U.S. Geological Survey Water-Resources Investigations Report 02-4193, $67 \mathrm{p}$.

Ortiz, A.G., 2008a, Potentiometric surface of the Upper Floridan aquifer, west-central Florida, May 2007: U.S. Geological Survey Open-File Report 2007-1380, 1 sheet.

Ortiz, A.G., 2008b, Potentiometric surface of the Upper Floridan aquifer, west-central Florida, September 2007: U.S. Geological Survey Open-File Report 2008-1105, 1 sheet.

Ortiz, A.G., 2008c, Potentiometric surface of the Upper Floridan aquifer, west-central Florida, May 2008: U.S. Geological Survey Scientific Investigations Map 3057, 1 sheet.

Ortiz, A.G., 2009, Potentiometric surface of the Upper Floridan aquifer, west-central Florida, September 2008: U.S. Geological Survey Scientific Investigations Map 3071, 1 sheet.

Plummer, L.N., and Busenberg, Eurybiades, 2000, Chlorofluorocarbons, chap. 15 of Cook, P.G. and Herczeg, A.L., eds., Environmental Tracers in Subsurface Hydrology: Boston, Kluwer Academic Publishers, p. 441-478.

Plummer, L.N., Prestemon, E.C., and Parkhurst, D.L., 1991, An interactive code (NETPATH) for modeling NET geochemical reactions along a flow PATH - version 2.0: U.S. Geological Survey Water Resources Investigations Report 94-4169, $132 \mathrm{p}$.

Plummer, L.N., and Sprinkle, C.L., 2001, Radiocarbon dating of dissolved inorganic carbon in groundwater from confined parts of the Upper Floridan aquifer, Florida, USA: Hydrogeology Journal, v. 9, p. 127-150.

Rantz, S.E., and others, 1982, Measurement and computation of streamflow: U.S. Geological Survey Water-Supply Paper 2175, 2 v., $631 \mathrm{p}$. 
Reston Chlorofluorocarbon Laboratory, 2009, Dating with $\mathrm{SF}_{6}$ background: Accessed online April 14, 2009, at http://water. usgs.gov/lab/sf6/background/.

Ryder, P.D., 1985, Hydrology of the Floridan aquifer system in west-central Florida: U.S. Geological Survey Professional Paper 1403-F, 63 p.

Sacks, L.A., 1996, Geochemical and isotopic composition of ground water with emphasis on sources of sulfate in the Upper Floridan Aquifer in parts of Marion, Sumter, and Citrus Counties, Florida: U.S. Geological Survey WaterResources Investigations Report 95-4251, 47 p.

Sacks, L.A., 2002, Estimating ground-water inflow to lakes in central Florida using the isotope mass-balance approach: U.S. Geological Survey Water-Resources Investigations Report 02-4192, 47 p.

Sacks, L.A., Lee, T.M., and Radell, M.J., 1994, Comparison of energy budget evaporation losses from two morphometrically different Florida seepage lakes: Journal of Hydrology, v. 156 , p. $311-334$.

Sacks, L.A., Swancar, Amy, and Lee, T.M., 1998, Estimating ground-water interaction with lakes using water-budget and chemical mass-balance approaches for ten lakes in ridge areas of Polk and Highlands Counties, Florida: U.S. Geological Survey Water-Resources Investigations Report 98-4133, $51 \mathrm{p}$.

Saur, J.F.T., and Anderson, E.R., 1956, The heat budget of a body of water of varying volume: Limnology and Oceanography, v. 1, no. 4, p. 247-251.

Schiffer, D.M., 1998, Hydrology of central Florida lakesA primer: U.S. Geological Survey Circular 1137, 38 p.

Scott, T.M., 2001, Text to accompany the geologic map of Florida: Florida Geological Survey Open File Report 80, $30 \mathrm{p}$.

Sepulveda, Nicasio, 2002, Simulation of ground-water flow in the intermediate and Floridan aquifer systems in peninsular Florida: U.S. Geological Survey Water-Resources Investigations Report 02-4009, 138 p.

Simonds, E.P., and German, E.R., 1980, Hydrology of the Lake Deaton and Lake Okahumpka Area, Northeast Sumter County, Florida: U.S. Geological Survey Water-Resources Investigations Open-File Report 80-733, 1 sheet.

Solomon, D.K., and Cook, P.G., 2000, ${ }^{3} \mathrm{H}$ and ${ }^{3} \mathrm{He}$, chap. 13 of Cook, P.G. and Herczeg, A.L., eds., Environmental Tracers in Subsurface Hydrology: Boston, Kluwer Academic Publishers, p. 397-424.
Southwest Florida Water Management District, 1991, Groundwater quality of the Southwest Florida Water Management District, northern region, section 2: Brooksville, $275 \mathrm{p}$.

Southwest Florida Water Management District, 2000, Lake Panasoffkee surface water improvement and management (S.W.I.M.) plan: Brooksville, 54 p.

Southwest Florida Water Management District, 2006, Minimum and guidance levels for Lake Panasoffkee in Sumter County, Florida: Brooksville, 24 p.

Southwest Florida Water Management District, 2009, 2007 Estimated water use in the Southwest Florida Water Management District: Brooksville, 246 p.

Southwest Florida Water Management District, 2010, Digital orthophotos: Accessed online July 2, 2010, at http://www. swfwmd.state.fl.us/data/gis/doqq_search.php.

Spechler, R.M. and Schiffer, D.M., 1995, Springs of Florida: U.S. Geological Survey Fact Sheet FS-151-95, 2 p.

Swancar, A., Lee, T.M., and O'Hare, T.M., 2000, Hydrogeologic setting, water budget, and preliminary analysis of ground-water exchange with Lake Starr, a seepage lake in Polk County Florida: U.S. Geological Survey WaterResources Investigations Report 00-4030, 65 p.

Swarzenski, P.W., 2004, An autonomous, electromagnetic seepage meter to study coastal groundwater/surface-water exchange: U.S. Geological Survey Open-File Report 1369, $4 \mathrm{p}$.

Tamers, M.A., 1975, Validity of radiocarbon dates on groundwater: Surveys in Geophysics, v. 2, no. 2, p. 217-239.

Taylor, G.F., 1977, Hydrology of Lake Panasoffkee, Sumter County, Florida: U.S. Geological Survey Water Resources Investigation Open-File Report 77-88, 1 sheet.

Tihansky, A.B., Arthur, J.D., and DeWitt, D.W., 1996, Sublake geologic structure from high-resolution seismic-reflection data from four sinkhole lakes in the Lake Wales Ridge, central Florida: U.S. Geological Survey Open-File Report 96-224, $72 \mathrm{p}$.

Trommer, J.T., Yobbi, D.K., and McBride, W.S., 2009, Surface- and groundwater interactions along the Withlacoochee River, west-central Florida: U.S. Geological Survey Scientific Investigations Report 2009-5124, 65 p.

University of Miami Tritium Laboratory, 2009, The Tritium Laboratory: Accessed online October 29, 2009, at http:// www.rsmas.miami.edu/groups/tritium/. 
U.S. Department of Agriculture, 2007, Census of agriculture, Sumter County - Florida: Accessed online March 4, 2010, at http://www.agcensus.usda.gov/Publications/2007/Online_ Highlights/County_Profiles/Florida/cp12119.pdf.

U.S. Geological Survey, variously dated, National field manual for the collection of water-quality data: U.S. Geological Survey Techniques of Water-Resources Investigations, book 9, chap. A1-A9: Available online at http://pubs. water.usgs.gov/twri9a.

U.S. Geological Survey, 2009, Water-resources data for the United States-Water year 2008: Available online at http:// wdr.water.usgs.gov/wy2008/search.jsp.

Vernon, R.O., 1951, Geology of Citrus and Levy Counties, Florida: Tallahassee, Florida Geological Survey Geological Bulletin 33, $256 \mathrm{p}$.
Wharton, B.R., 1982, Historic analysis of the rock spillway at Outlet River and Lake Panasoffkee, Sumter County, Florida: Brooksville, Southwest Florida Water Management District report, $6 \mathrm{p}$.

White, William, 1958, Some geomorphic features of central peninsular Florida: Tallahassee, Florida Geological Survey Geological Bulletin 41, 92 p.

White, William, 1970, The geomorphology of the Florida Peninsula: Tallahassee, Florida Geological Survey Geological Bulletin 51, 164 p. 


\section{Appendix 1. Elevation of water levels in all wells used to create Upper Floridan aquifer potentiometric-surface maps}


Appendix 1. Elevation of water levels in all wells used to create Upper Floridan aquifer potentiometric-surface maps.

[USGS, U.S. Geological Survey; NGVD 29, National Geodetic Vertical Datum of 1929; FLRD, Upper Floridan aquifer (UFA) well; WMA, wildlife management area; SWFWMD, Southwest Florida Water Management District; ft, feet; nr, near; dp, deep; —, no data]

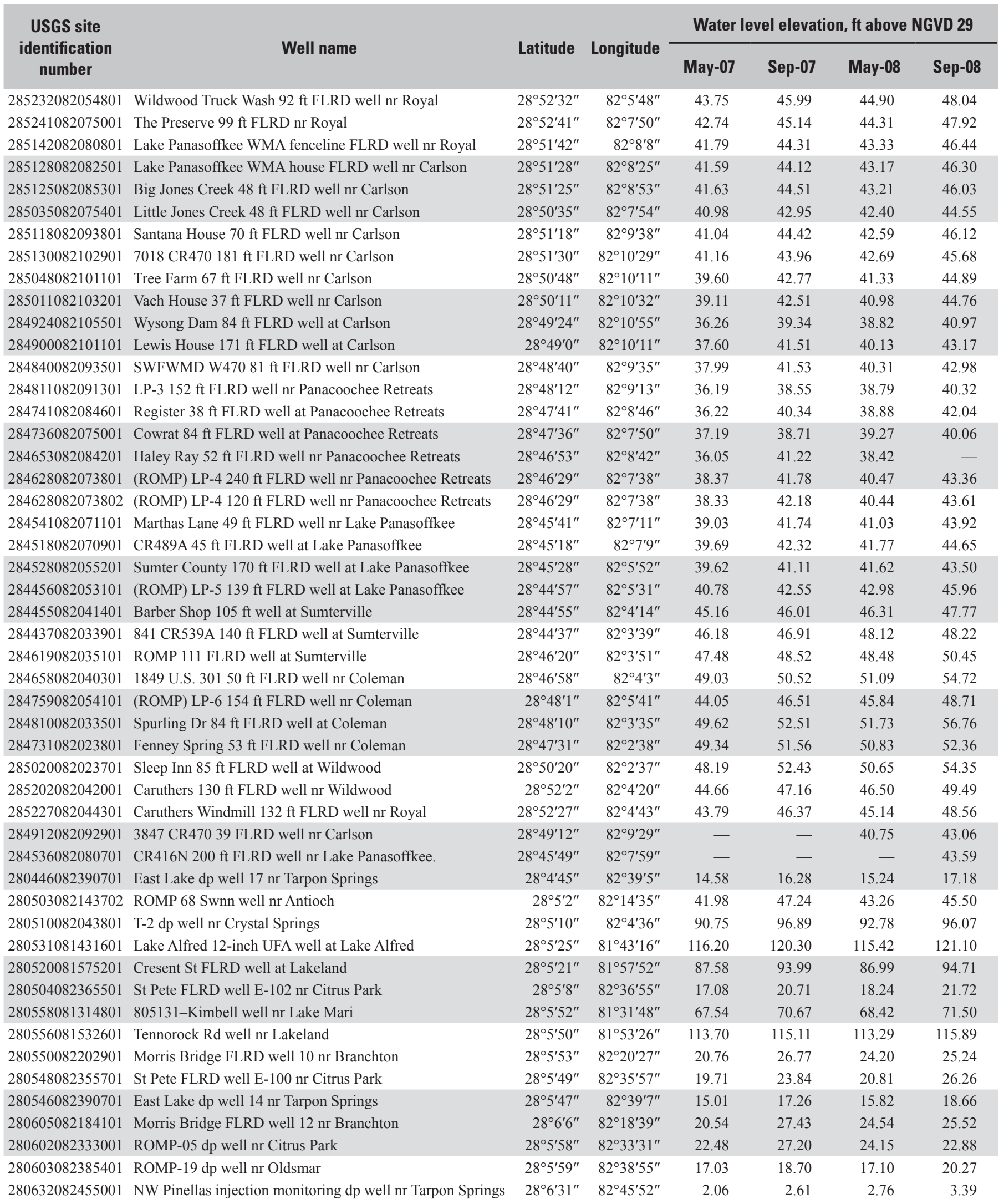


Appendix 1. Elevation of water levels in all wells used to create Upper Floridan aquifer potentiometric surface maps. — Continued

[USGS, U.S. Geological Survey; NGVD 29, National Geodetic Vertical Datum of 1929; FLRD, Upper Floridan aquifer (UFA) well; WMA, wildlife management area; SWFWMD, Southwest Florida Water Management District; ft, feet; nr, near; dp, deep; —, no data]

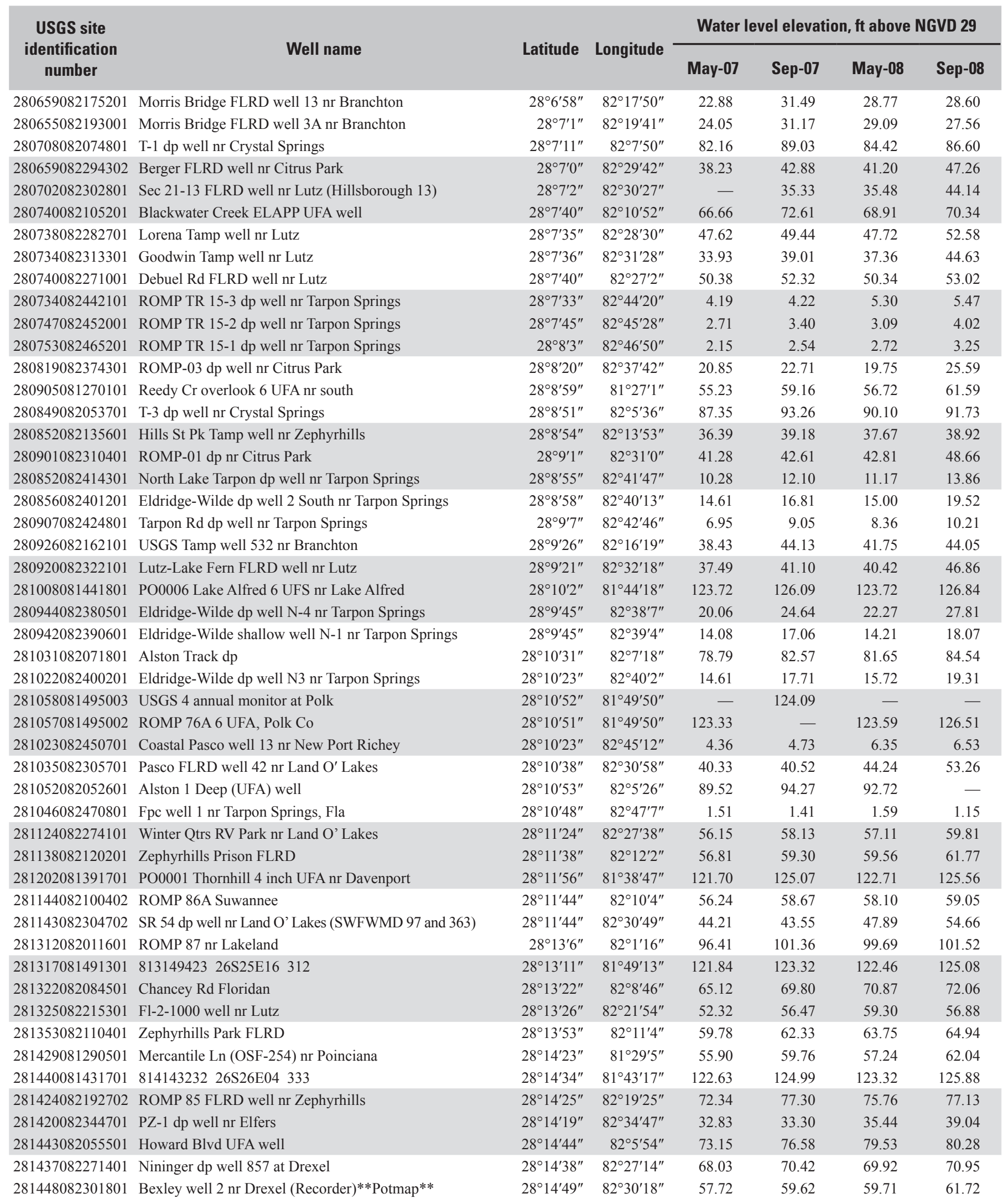


Appendix 1. Elevation of water levels in all wells used to create Upper Floridan aquifer potentiometric surface maps. — Continued

[USGS, U.S. Geological Survey; NGVD 29, National Geodetic Vertical Datum of 1929; FLRD, Upper Floridan aquifer (UFA) well; WMA, wildlife management area; SWFWMD, Southwest Florida Water Management District; ft, feet; nr, near; dp, deep; —, no data]

\begin{tabular}{|c|c|c|c|c|c|c|c|}
\hline $\begin{array}{c}\text { USGS site } \\
\text { identification } \\
\text { number }\end{array}$ & Well name & Latitude & Longitude & \multicolumn{4}{|c|}{ Water level elevation, ft above NGVD 29} \\
\hline 281446082354101 & MW-1 dp well nr Elfers & $28^{\circ} 14^{\prime} 48^{\prime \prime}$ & $82^{\circ} 35^{\prime} 40^{\prime \prime}$ & 24.92 & 24.94 & 30.89 & 33.89 \\
\hline 281457082334301 & PZ-3 dp well nr Elfers & $28^{\circ} 14^{\prime} 52^{\prime \prime}$ & $82^{\circ} 33^{\prime} 43^{\prime \prime}$ & 37.87 & 40.27 & 41.22 & 43.34 \\
\hline 281451082380701 & Starky $10 \mathrm{dp}$ well $\mathrm{nr}$ Elfers & $28^{\circ} 14^{\prime} 51^{\prime \prime}$ & $82^{\circ} 38^{\prime} 7^{\prime \prime}$ & 22.89 & 22.79 & 24.69 & 27.40 \\
\hline 281532081493001 & USGS shallow well W5470 nr Polk Co & $28^{\circ} 15^{\prime} 26^{\prime \prime}$ & $81^{\circ} 49^{\prime} 30^{\prime \prime}$ & 120.09 & 121.57 & 121.06 & 122.85 \\
\hline 281532081345001 & Loughman dp (Orlando also) & $28^{\circ} 15^{\prime} 34^{\prime \prime}$ & $81^{\circ} 34^{\prime} 50^{\prime \prime}$ & 86.79 & 89.80 & 88.67 & 90.23 \\
\hline 281533082130601 & Austin Smith Rd FLRD & $28^{\circ} 15^{\prime} 33^{\prime \prime}$ & $82^{\circ} 13^{\prime} 6^{\prime \prime}$ & 61.69 & 63.82 & 65.71 & 66.65 \\
\hline 281559081260701 & Shingle Creek 4 inch UFA, SR 531A & $28^{\circ} 15^{\prime} 53^{\prime \prime}$ & $81^{\circ} 26^{\prime} 7^{\prime \prime}$ & 49.47 & 53.38 & 50.65 & 57.18 \\
\hline 281518082424301 & ROMP TR 16-2 Van Buren - SWNN & $28^{\circ} 15^{\prime} 18^{\prime \prime}$ & $82^{\circ} 42^{\prime} 40^{\prime \prime}$ & 4.64 & 6.05 & 5.32 & 6.30 \\
\hline 281558082264601 & Pasco well 13 nr Drexel & $28^{\circ} 15^{\prime} 60^{\prime \prime}$ & $82^{\circ} 26^{\prime} 46^{\prime \prime}$ & 68.92 & 70.44 & 70.38 & 71.68 \\
\hline 281622082241301 & Cypress Creek dp well $3 \mathrm{nr}$ San Antonio & $28^{\circ} 16^{\prime} 23^{\prime \prime}$ & $82^{\circ} 24^{\prime} 12^{\prime \prime}$ & 49.26 & 49.14 & 52.00 & 52.58 \\
\hline 281631082261601 & Catchings well nr Drexel & $28^{\circ} 16^{\prime} 29^{\prime \prime}$ & $82^{\circ} 26^{\prime} 14^{\prime \prime}$ & 62.87 & 64.68 & 64.03 & 67.61 \\
\hline 281654082065901 & US 98 well nr Dade Co & $28^{\circ} 16^{\prime} 48^{\prime \prime}$ & $82^{\circ} 6^{\prime} 59^{\prime \prime}$ & 72.45 & 73.85 & 75.92 & 75.36 \\
\hline 281654082201601 & Carr dp well nr San Antonio & $28^{\circ} 16^{\prime} 49^{\prime \prime}$ & $82^{\circ} 20^{\prime} 17^{\prime \prime}$ & 71.39 & 73.65 & - & - \\
\hline 281636082372001 & Moon Lake dp well nr New Port Richey & $28^{\circ} 16^{\prime} 42^{\prime \prime}$ & $82^{\circ} 37^{\prime} 15^{\prime \prime}$ & 27.67 & 27.56 & 27.94 & 29.80 \\
\hline 281650082244501 & Cypress Creek dp well TMR-4 nr San Antonio & $28^{\circ} 16^{\prime} 51^{\prime \prime}$ & $82^{\circ} 24^{\prime} 45^{\prime \prime}$ & 50.75 & 51.29 & 53.51 & 54.13 \\
\hline 281642082440201 & Coastal Pasco dp well 04 atPort Richey & $28^{\circ} 16^{\prime} 42^{\prime \prime}$ & $82^{\circ} 44^{\prime} 2^{\prime \prime}$ & 0.42 & 0.00 & 0.93 & -0.51 \\
\hline 281715082164401 & SR $577 \mathrm{dp}$ well $\mathrm{nr}$ San Antonio & $28^{\circ} 17^{\prime} 16^{\prime \prime}$ & $82^{\circ} 16^{\prime} 44^{\prime \prime}$ & 78.99 & 80.91 & 82.89 & 83.78 \\
\hline 281837081544101 & ROMP 88 nr Rockridge & $28^{\circ} 18^{\prime} 31^{\prime \prime}$ & $81^{\circ} 54^{\prime} 41^{\prime \prime}$ & & 105.01 & 101.60 & 104.07 \\
\hline 281918082264601 & SR 52 dp well nr Gowers Corner & $28^{\circ} 19^{\prime} 19^{\prime \prime}$ & $82^{\circ} 26^{\prime} 46^{\prime \prime}$ & 66.66 & 68.97 & 67.31 & 69.76 \\
\hline 281948082415301 & Withlacoochee elec well \#1 at Bayonet Pt & $28^{\circ} 19^{\prime} 51^{\prime \prime}$ & $82^{\circ} 41^{\prime} 50^{\prime \prime}$ & 1.17 & 2.31 & 1.61 & 2.09 \\
\hline 281954082413401 & Ponderosa Dev well at Bayonet Pt & $28^{\circ} 19^{\prime} 57^{\prime \prime}$ & $82^{\circ} 41^{\prime} 36^{\prime \prime}$ & 1.98 & 2.85 & - & 1.70 \\
\hline 282009082373801 & SR $52 \mathrm{dp}$ well nr Hudson & $28^{\circ} 20^{\prime} 14^{\prime \prime}$ & $82^{\circ} 37^{\prime} 28^{\prime \prime}$ & 21.55 & 22.25 & 22.73 & 23.96 \\
\hline 282035082283701 & Serw-D dp well nr Masaryktown & $28^{\circ} 20^{\prime} 35^{\prime \prime}$ & $82^{\circ} 28^{\prime} 35^{\prime \prime}$ & 63.07 & 65.38 & 63.53 & 67.19 \\
\hline 282044082312401 & H Kent dp well nr Gowers Corner & $28^{\circ} 20^{\prime} 45^{\prime \prime}$ & $82^{\circ} 31^{\prime} 23^{\prime \prime}$ & 55.24 & 56.39 & 55.63 & 58.89 \\
\hline 282121082071101 & Cummer office well & $28^{\circ} 21^{\prime} 15^{\prime \prime}$ & $82^{\circ} 7^{\prime} 11^{\prime \prime}$ & 68.09 & 70.30 & 71.10 & 70.54 \\
\hline 282202081384601 & OR0064 Lake Oliver 6 UFA nr Lake Oliver & $28^{\circ} 21^{\prime} 56^{\prime \prime}$ & $81^{\circ} 38^{\prime} 46^{\prime \prime}$ & 105.06 & 106.24 & 105.65 & 107.22 \\
\hline 282154082142401 & Haycraft well nr Dade Co & $28^{\circ} 21^{\prime} 48^{\prime \prime}$ & $82^{\circ} 14^{\prime} 24^{\prime \prime}$ & 60.32 & 61.86 & 63.57 & 64.10 \\
\hline 282148082281801 & Crossbar WFA-1 dp & $28^{\circ} 21^{\prime} 49^{\prime \prime}$ & $82^{\circ} 28^{\prime} 17^{\prime \prime}$ & 53.19 & 56.02 & 52.92 & 56.36 \\
\hline 282221082103001 & Collura well \#1 & $28^{\circ} 22^{\prime} 15^{\prime \prime}$ & $82^{\circ} 10^{\prime} 30^{\prime \prime}$ & 60.58 & 62.07 & - & - \\
\hline 282202082270801 & Serw-D well nr Masaryktown & $28^{\circ} 22^{\prime} 10^{\prime \prime}$ & $82^{\circ} 27^{\prime} 10^{\prime \prime}$ & 54.47 & 56.77 & 54.97 & 59.78 \\
\hline 282241081443901 & L-0051 sand mine UFA & $28^{\circ} 22^{\prime} 35^{\prime \prime}$ & $81^{\circ} 44^{\prime} 39^{\prime \prime}$ & 112.64 & 113.32 & 112.70 & 115.65 \\
\hline 282245081492601 & L-0057 Eva 6 inch UFA at Eva (dp) & $28^{\circ} 22^{\prime} 39^{\prime \prime}$ & $81^{\circ} 49^{\prime} 26^{\prime \prime}$ & 106.39 & 108.31 & 107.45 & 110.12 \\
\hline 282229082405801 & Coastal Pasco dp well 02 at Hudson & $28^{\circ} 22^{\prime} 30^{\prime \prime}$ & $82^{\circ} 40^{\prime} 56^{\prime \prime}$ & 1.87 & 1.78 & 2.23 & 1.94 \\
\hline 282238082362101 & Justice dp nr Hudson & $28^{\circ} 22^{\prime} 42^{\prime \prime}$ & $82^{\circ} 36^{\prime} 17^{\prime \prime}$ & 19.70 & 21.52 & - & 23.80 \\
\hline 282318081544003 & L-0555 Green Swamp test & $28^{\circ} 23^{\prime} 12^{\prime \prime}$ & $81^{\circ} 54^{\prime} 40^{\prime \prime}$ & 98.42 & 100.96 & 100.64 & 102.58 \\
\hline 282331081370801 & USGS well Hartzog Rd & $28^{\circ} 23^{\prime} 25^{\prime \prime}$ & $81^{\circ} 37^{\prime} 8^{\prime \prime}$ & - & 101.19 & 99.04 & 101.85 \\
\hline 282354081313001 & Disney World Buena Vista Blvd & $28^{\circ} 23^{\prime} 48^{\prime \prime}$ & $81^{\circ} 31^{\prime} 30^{\prime \prime}$ & 72.65 & - & - & - \\
\hline 282324082285101 & Wrw-D well nr Masaryktown & $28^{\circ} 23^{\prime} 25^{\prime \prime}$ & $82^{\circ} 28^{\prime} 52^{\prime \prime}$ & 39.27 & 40.08 & 39.28 & 43.93 \\
\hline
\end{tabular}


Appendix 1. Elevation of water levels in all wells used to create Upper Floridan aquifer potentiometric surface maps. — Continued

[USGS, U.S. Geological Survey; NGVD 29, National Geodetic Vertical Datum of 1929; FLRD, Upper Floridan aquifer (UFA) well; WMA, wildlife management area; SWFWMD, Southwest Florida Water Management District; ft, feet; nr, near; dp, deep; —, no data]

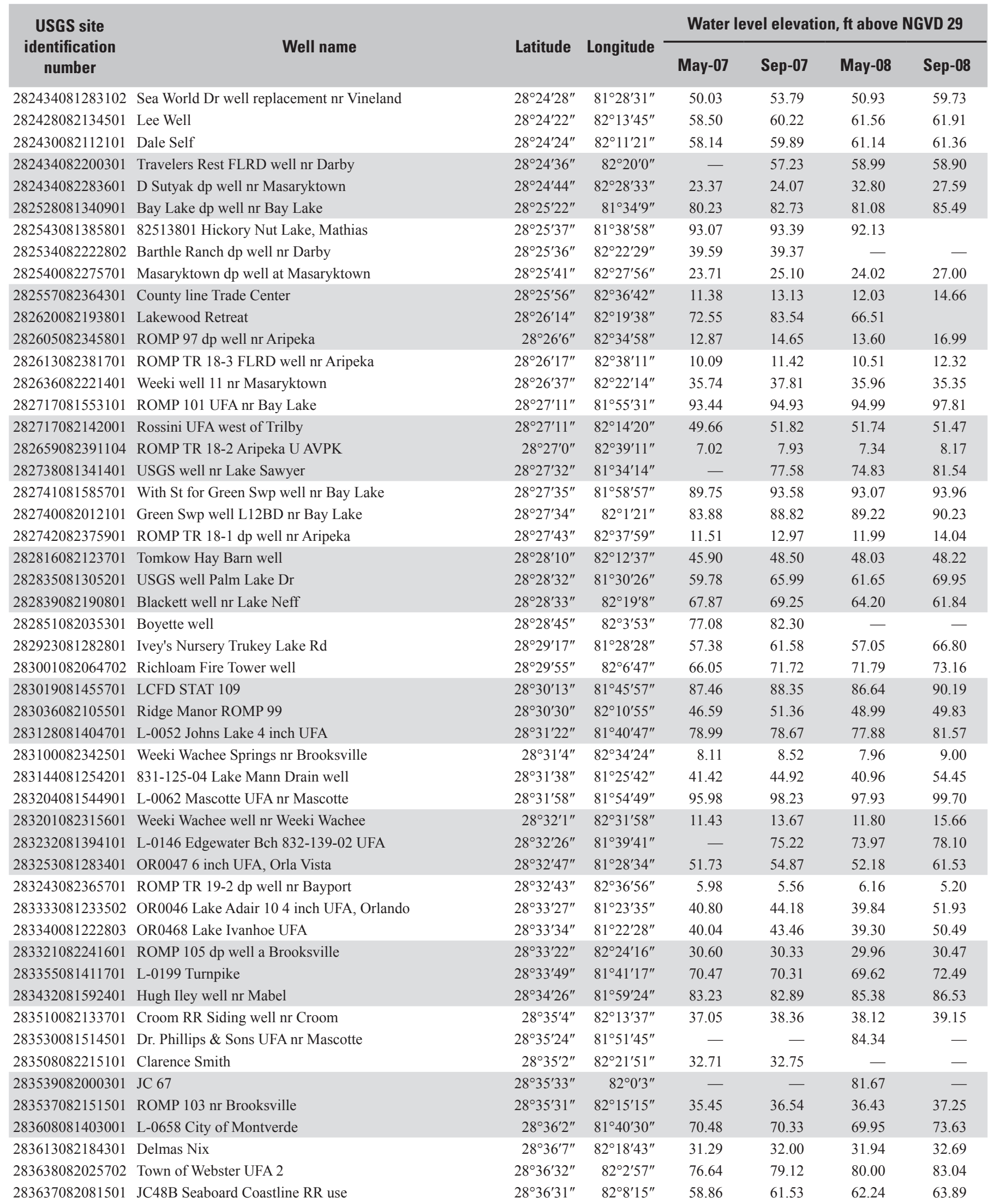


Appendix 1. Elevation of water levels in all wells used to create Upper Floridan aquifer potentiometric surface maps. — Continued

[USGS, U.S. Geological Survey; NGVD 29, National Geodetic Vertical Datum of 1929; FLRD, Upper Floridan aquifer (UFA) well; WMA, wildlife management area; SWFWMD, Southwest Florida Water Management District; ft, feet; nr, near; dp, deep; -, no data]

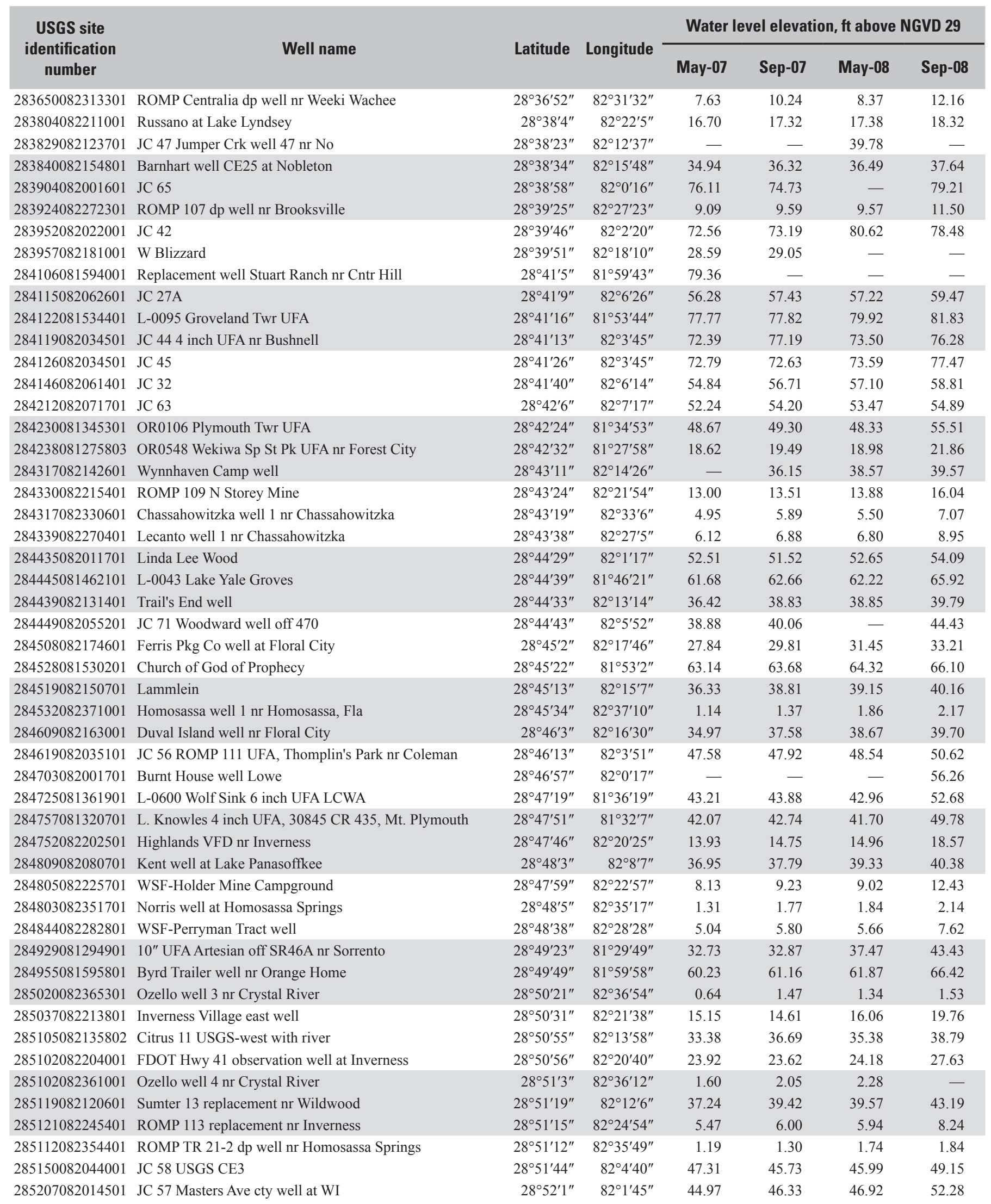


Appendix 1. Elevation of water levels in all wells used to create Upper Floridan aquifer potentiometric surface maps. — Continued

[USGS, U.S. Geological Survey; NGVD 29, National Geodetic Vertical Datum of 1929; FLRD, Upper Floridan aquifer (UFA) well; WMA, wildlife management area; SWFWMD, Southwest Florida Water Management District; ft, feet; nr, near; dp, deep; —, no data]

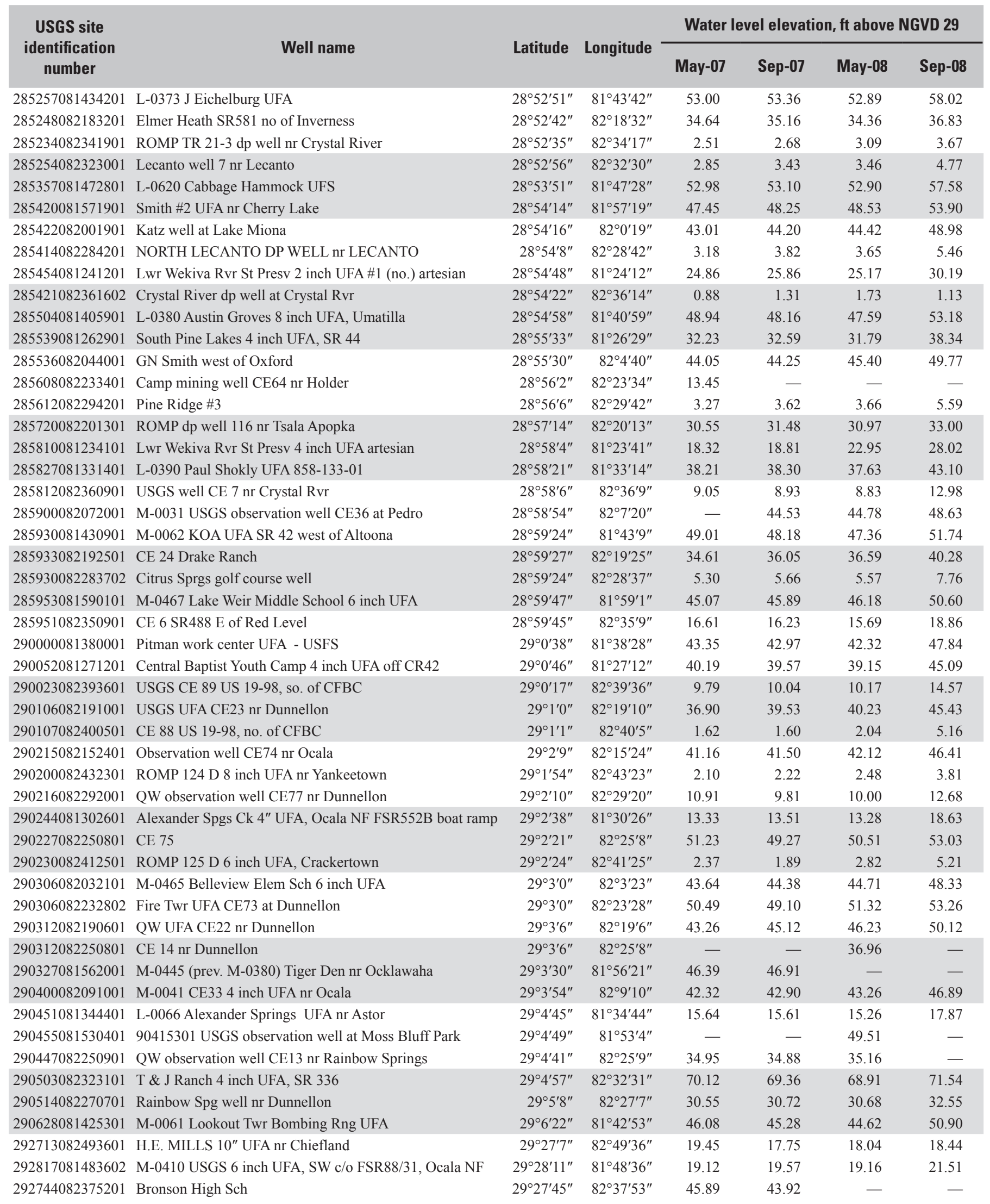


Appendix 1. Elevation of water levels in all wells used to create Upper Floridan aquifer potentiometric surface maps. — Continued

[USGS, U.S. Geological Survey; NGVD 29, National Geodetic Vertical Datum of 1929; FLRD, Upper Floridan aquifer (UFA) well; WMA, wildlife management area; SWFWMD, Southwest Florida Water Management District; ft, feet; nr, near; dp, deep; —, no data]

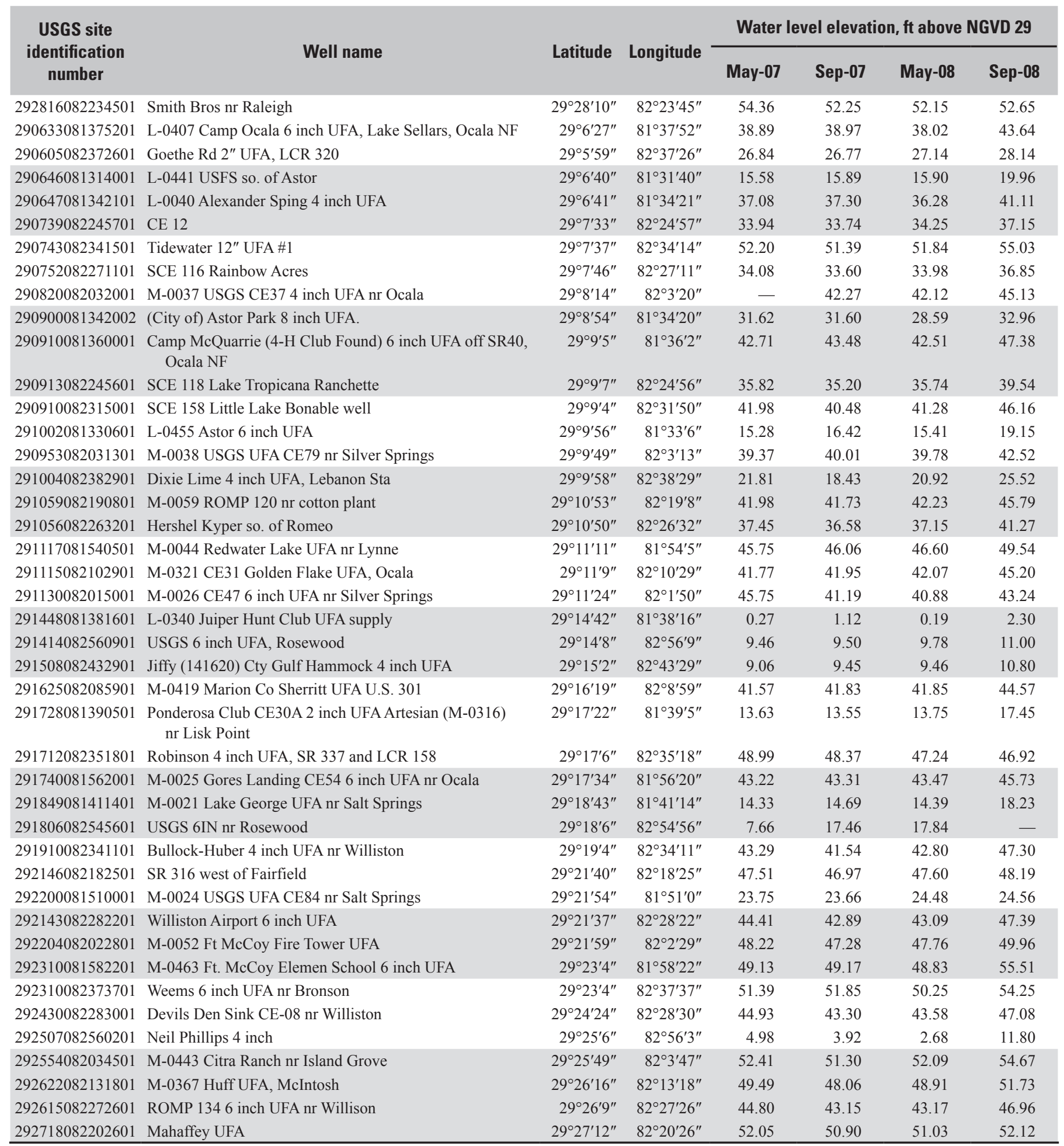




\section{Appendix 2. Major ion, nutrient, and field parameter water-quality data from the Lake Panasoffkee study area, July 2007, and December 2008 through January 2009}


Appendix 2. Major ion, nutrient, and field parameter water-quality data in the Lake Panasoffkee watershed, July 2007 and December 2008 through January 2009. The columns of this table showing constituent values continue on the following two pages.

[USGS, U.S. Geological Survey; <, less than; E, estimated; ft, feet; nr, near; $\mathrm{CaCO}_{3}$, calcium carbonate; ${ }^{\circ} \mathrm{C}$, degrees Celcius; NA, not applicable; LFA, Lower Floridan aquifer; mg/L, milligrams per liter; SA, surficial aquifer; SPG, spring; SW, surface water; UFA, Upper Floridan aquifer; $\mu \mathrm{S} / \mathrm{cm}$, microsiemens per centimeter; $\mu \mathrm{g} / \mathrm{L}$, micrograms per liter]

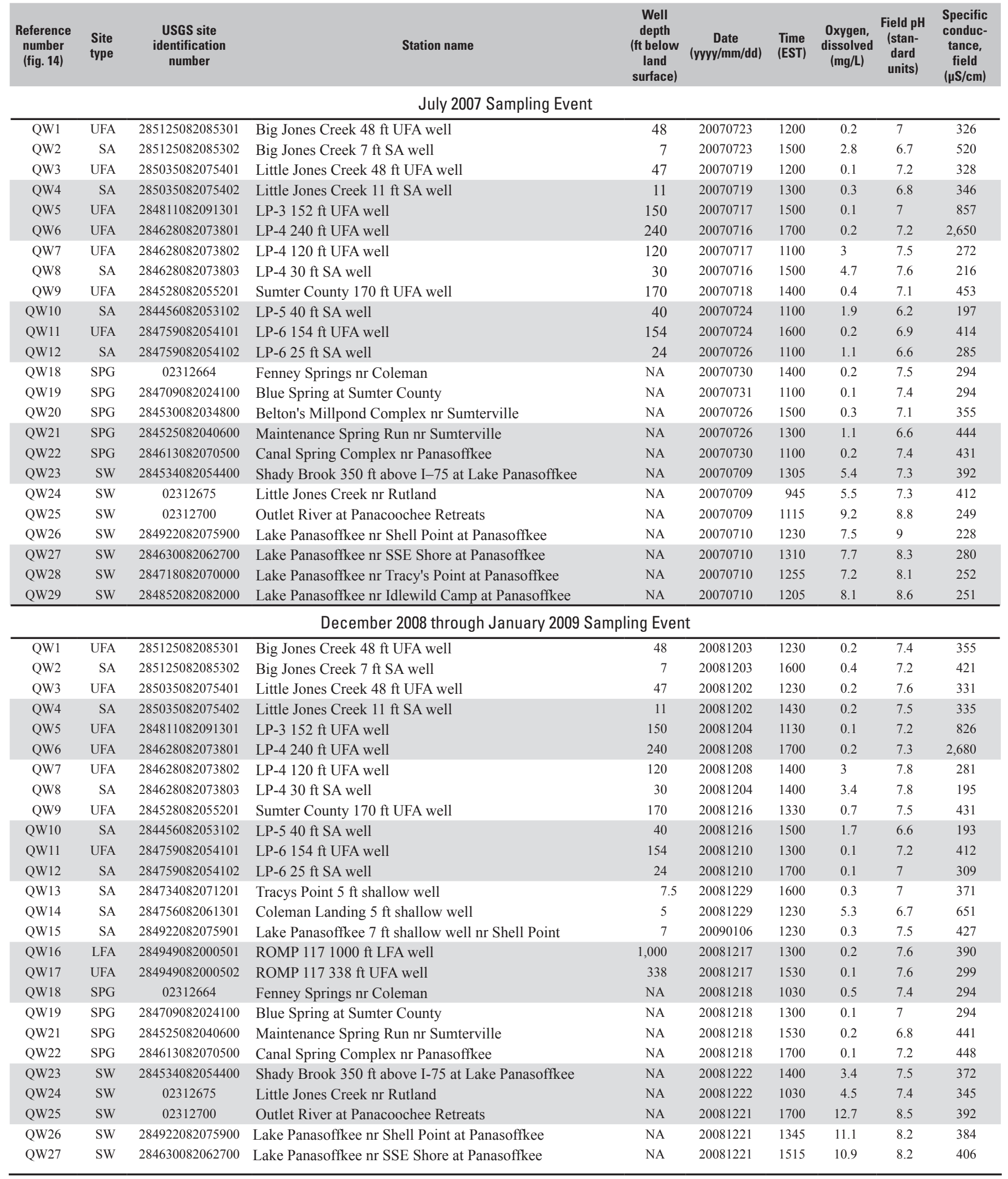


Appendix 2. Major ion, nutrient, and field parameter water-quality data in the Lake Panasoffkee watershed, July 2007 and December 2008 through January 2009. — Continued

[USGS, U.S. Geological Survey; <, less than; E, estimated; ft, feet; nr, near; $\mathrm{CaCO}_{3}$, calcium carbonate; ${ }^{\circ} \mathrm{C}$, degrees Celcius; NA, not applicable; LFA, Lower Floridan aquifer; mg/L, milligrams per liter; SA, surficial aquifer; SPG, spring; SW, surface water; UFA, Upper Floridan aquifer; $\mu \mathrm{S} / \mathrm{cm}$, microsiemens per centimeter; $\mu \mathrm{g} / \mathrm{L}$, micrograms per liter]

\begin{tabular}{|c|c|c|c|c|c|c|c|c|c|c|c|}
\hline $\begin{array}{l}\text { Reference } \\
\text { number } \\
\text { (fig. 14) }\end{array}$ & $\begin{array}{l}\text { Site } \\
\text { type }\end{array}$ & $\begin{array}{l}\text { USGS site } \\
\text { identification } \\
\text { number }\end{array}$ & $\begin{array}{c}\text { Temp- } \\
\text { erature, } \\
\text { water } \\
\left({ }^{\circ} \mathrm{C}\right)\end{array}$ & $\begin{array}{c}\text { Cal- } \\
\text { cium, } \\
\text { dissolved } \\
\text { (mg/L) }\end{array}$ & $\begin{array}{l}\text { Magne- } \\
\text { sium, } \\
\text { dissolved } \\
\text { (mg/L) }\end{array}$ & $\begin{array}{l}\text { Potas- } \\
\text { sium, } \\
\text { dissolved } \\
\text { (mg/L) }\end{array}$ & $\begin{array}{l}\text { Sodium, } \\
\text { dissolved } \\
\text { (mg/L) }\end{array}$ & $\begin{array}{c}\text { Alka- } \\
\text { linity, } \\
\text { field } \\
\text { (mg/L as } \\
\text { CaCO3) }\end{array}$ & $\begin{array}{c}\text { Bromide, } \\
\text { dis- } \\
\text { solved } \\
\text { (mg/L) }\end{array}$ & $\begin{array}{c}\text { Chloride, } \\
\text { dissolved } \\
\text { (mg/L) }\end{array}$ & $\begin{array}{c}\text { Silica, } \\
\text { dissolved } \\
\text { (mg/L) }\end{array}$ \\
\hline \multicolumn{12}{|c|}{ July 2007 Sampling Event } \\
\hline QW1 & $\overline{\text { UFA }}$ & 285125082085301 & 23.3 & 53.8 & 5.2 & 0.26 & 4.21 & 144 & 0.03 & 6.49 & 8.03 \\
\hline QW2 & SA & 285125082085302 & 25 & 87.5 & 6.88 & 0.3 & 6.5 & 254 & 0.06 & 9.22 & 9.7 \\
\hline QW3 & UFA & 285035082075401 & 23.2 & 48.9 & 5.77 & 1.37 & 11 & 125 & E 0.01 & 6.18 & 11.9 \\
\hline QW4 & SA & 285035082075402 & 25.3 & 57.8 & 5.98 & 0.24 & 4.09 & 138 & 0.03 & 6.11 & 10.5 \\
\hline QW5 & UFA & 284811082091301 & 24.5 & 139 & 27.6 & 1.16 & 6.38 & 253 & 0.04 & 8.98 & 13.8 \\
\hline QW6 & UFA & 284628082073801 & 26 & 528 & 123 & 2.8 & 11.4 & 117 & 0.07 & 14.9 & 14.3 \\
\hline QW7 & UFA & 284628082073802 & 25.8 & 42.1 & 2.46 & 0.97 & 5.24 & 87 & E 0.02 & 7.08 & 4.76 \\
\hline QW8 & SA & 284628082073803 & 26.5 & 38.7 & 3.42 & 1.19 & 1.85 & 89 & $<0.02$ & 3.16 & 3.86 \\
\hline QW9 & UFA & 284528082055201 & 25.4 & 78.2 & 8.47 & 0.72 & 5.25 & 152 & 0.03 & 7.62 & 10.2 \\
\hline QW10 & SA & 284456082053102 & 25.1 & 28.9 & 1.74 & 1.09 & 7.19 & 81 & 0.04 & 7.19 & 6.72 \\
\hline QW11 & UFA & 284759082054101 & 23.4 & 78.8 & 2.64 & 0.27 & 4.1 & 210 & 0.03 & 6.62 & 9.45 \\
\hline QW12 & SA & 284759082054102 & 23.9 & 52.5 & 1.94 & 0.3 & 4.11 & 135 & 0.04 & 8.27 & 8.4 \\
\hline QW18 & SPG & 02312664 & 23.3 & 50.7 & 2.49 & 0.63 & 4.33 & 134 & 0.02 & 7.72 & 8.85 \\
\hline QW19 & SPG & 284709082024100 & 23.4 & 51.8 & 2.08 & 0.59 & 4.48 & 131 & 0.03 & 7.83 & 8.27 \\
\hline QW20 & SPG & 284530082034800 & 21.8 & 62.4 & 2.73 & 0.66 & 4.92 & 162 & 0.04 & 8.25 & 5.73 \\
\hline QW21 & SPG & 284525082040600 & 23.7 & 82.9 & 3.04 & 0.58 & 4.92 & 216 & 0.03 & 8.17 & 6.79 \\
\hline QW22 & SPG & 284613082070500 & 23.7 & 73.9 & 5.21 & 0.76 & 4.75 & 144 & 0.05 & 8.08 & 6.86 \\
\hline QW23 & SW & 284534082054400 & 27.5 & 74.2 & 3.03 & 0.63 & 5.26 & 161 & 0.04 & 9.04 & 8.66 \\
\hline QW24 & SW & 02312675 & 26.1 & 72.4 & 6.05 & 0.76 & 5.97 & 137 & 0.04 & 9.41 & 11.2 \\
\hline QW25 & SW & 02312700 & 31.8 & 32.9 & 6.01 & 1.03 & 7.49 & 59 & 0.07 & 12.5 & 8.4 \\
\hline QW26 & SW & 284922082075900 & 32.4 & 28.4 & 6.36 & 0.41 & 7.41 & 45 & 0.05 & 12 & 9.76 \\
\hline QW27 & SW & 284630082062700 & 33.1 & 46.3 & 4.24 & 0.29 & 5.37 & 93 & 0.05 & 9.14 & 6.23 \\
\hline QW28 & SW & 284718082070000 & 32.7 & 37.1 & 5.11 & 0.17 & 6.11 & 61 & 0.06 & 10.5 & 3.37 \\
\hline QW29 & SW & 284852082082000 & 31.6 & 34 & 6.04 & 0.79 & 7.03 & 64 & 0.07 & 11.5 & 11.2 \\
\hline \multicolumn{12}{|c|}{ December 2008 through January 2009 Sampling Event } \\
\hline QW1 & $\overline{\text { UFA }}$ & 285125082085301 & 22.5 & 61.3 & 5.4 & 0.26 & 4.67 & 164 & 0.03 & 7.46 & 8.17 \\
\hline QW2 & SA & 285125082085302 & 19.3 & 76.2 & 5.98 & 0.23 & 5.72 & 210 & 0.03 & 8.91 & 8.7 \\
\hline QW3 & UFA & 285035082075401 & 21.8 & 53.2 & 6.05 & 0.52 & 5.09 & 132 & 0.03 & 6.04 & 11 \\
\hline QW4 & $\mathrm{SA}$ & 285035082075402 & 21.6 & 56.3 & 5.98 & 0.3 & 4.18 & 136 & 0.05 & 6.13 & 10 \\
\hline QW5 & UFA & 284811082091301 & 22.7 & 144 & 25.9 & 1.15 & 6.93 & 280 & 0.04 & 9.72 & 12 \\
\hline QW6 & UFA & 284628082073801 & 24.5 & 554 & 130 & 2.91 & 11.9 & 120 & 0.06 & 14.5 & 13.2 \\
\hline QW7 & UFA & 284628082073802 & 24.8 & 45 & 2.66 & 1.04 & 5.24 & 86 & E 0.02 & 7.09 & 4.96 \\
\hline QW8 & SA & 284628082073803 & 25.6 & 33.4 & 2.64 & 0.88 & 2.01 & 76 & E 0.02 & 3.3 & 3.5 \\
\hline QW9 & UFA & 284528082055201 & 24.2 & 75.2 & 8.31 & 0.86 & 5.31 & 138 & 0.03 & 8.31 & 9.47 \\
\hline QW10 & SA & 284456082053102 & 26.6 & 31.3 & 1.94 & 1.23 & 6.74 & 78 & 0.04 & 7.19 & 6.07 \\
\hline QW11 & UFA & 284759082054101 & 22.9 & 79.5 & 2.74 & 0.27 & 4.18 & 205 & 0.02 & 6.65 & 8.47 \\
\hline QW12 & SA & 284759082054102 & 23.1 & 55.1 & 2.14 & 0.34 & 4.24 & 145 & 0.03 & 7.64 & 9.24 \\
\hline QW13 & SA & 284734082071201 & 21.9 & 60.1 & 9.75 & 2.9 & 12.1 & 127 & 0.03 & 21.3 & 5.66 \\
\hline QW14 & SA & 284756082061301 & 19.9 & 130 & 2.68 & 2.06 & 4.86 & 346 & 0.09 & 5 & 3.94 \\
\hline QW15 & SA & 284922082075901 & 22.8 & 66.1 & 11.7 & 0.81 & 5.07 & 142 & 0.04 & 7.71 & 10.5 \\
\hline QW16 & LFA & 284949082000501 & 24 & 66.3 & 10.2 & 1.12 & 5.36 & 165 & 0.04 & 8.21 & 13.8 \\
\hline QW17 & UFA & 284949082000502 & 23 & 53.9 & 4.3 & 0.71 & 4.8 & 142 & 0.04 & 7.5 & 12.3 \\
\hline QW18 & SPG & 02312664 & 23.4 & 52.8 & 2.55 & 0.67 & 4.32 & 131 & 0.03 & 8.4 & 8.62 \\
\hline QW19 & SPG & 284709082024100 & 23.5 & 54.1 & 2.02 & 0.61 & 4.25 & 128 & 0.03 & 8.24 & 8.06 \\
\hline QW21 & SPG & 284525082040600 & 23.6 & 86.7 & 3.05 & 0.64 & 5.06 & 213 & 0.03 & 9.08 & 6.98 \\
\hline QW22 & SPG & 284613082070500 & 23.8 & 83.8 & 5.65 & 0.86 & 4.69 & 158 & 0.07 & 8.6 & 7.03 \\
\hline QW23 & SW & 284534082054400 & 17.4 & 76 & 3.06 & 0.55 & 5.57 & 177 & 0.03 & 9.78 & 8.18 \\
\hline QW24 & SW & 02312675 & 16.9 & 63.4 & 5.47 & 0.47 & 6.1 & 157 & 0.03 & 10.4 & 10.6 \\
\hline QW25 & SW & 02312700 & 20.1 & 75.7 & 5.43 & 1.5 & 6.79 & 179 & $<0.02$ & 11.8 & 14.9 \\
\hline QW26 & SW & 284922082075900 & 20.4 & 71.5 & 5.45 & 1.14 & 6.48 & 169 & E 0.01 & 11.4 & 13.3 \\
\hline QW27 & SW & 284630082062700 & 20.3 & 77.4 & 4.41 & 1.35 & 6.3 & 177 & $<0.02$ & 11.6 & 12.9 \\
\hline
\end{tabular}


Appendix 2. Major ion, nutrient, and field parameter water-quality data in the Lake Panasoffkee watershed, July 2007 and December 2008 through January 2009. — Continued

[USGS, U.S. Geological Survey; <, less than; E, estimated; ft, feet; $\mathrm{nr}$, near; $\mathrm{CaCO}_{3}$, calcium carbonate; ${ }^{\circ} \mathrm{C}$, degrees Celcius; NA, not applicable; LFA, Lower Floridan aquifer; mg/L, milligrams per liter; SA, surficial aquifer; SPG, spring; SW, surface water; UFA, Upper Floridan aquifer; $\mu \mathrm{S} / \mathrm{cm}$, microsiemens per centimeter; $\mu \mathrm{g} / \mathrm{L}$, micrograms per liter]

\begin{tabular}{|c|c|c|c|c|c|c|c|c|c|c|c|}
\hline $\begin{array}{l}\text { Reference } \\
\text { number } \\
\text { (fig. 14) }\end{array}$ & $\begin{array}{l}\text { Site } \\
\text { type }\end{array}$ & $\begin{array}{l}\text { USGS site } \\
\text { identification } \\
\text { number }\end{array}$ & $\begin{array}{l}\text { Sulfate, } \\
\text { dissolved } \\
\text { (mg/L) }\end{array}$ & $\begin{array}{c}\text { Ammonia } \\
\text { + organic } \\
\text { nitrogen } \\
\text { (mg/L) }\end{array}$ & $\begin{array}{c}\text { Ammonia } \\
\text { (mg/L) }\end{array}$ & $\begin{array}{c}\text { Nitrate } \\
+ \text { nitrite } \\
\text { (mg/L) }\end{array}$ & $\begin{array}{l}\text { Nitrite } \\
\text { (mg/L) }\end{array}$ & $\begin{array}{l}\text { Ortho- } \\
\text { phos- } \\
\text { phate } \\
\text { (mg/L) }\end{array}$ & $\begin{array}{l}\text { Phos- } \\
\text { phorus } \\
\text { (mg/L) }\end{array}$ & $\begin{array}{c}\text { Organic } \\
\text { carbon, } \\
\text { dissolved } \\
\text { (mg/L) }\end{array}$ & $\begin{array}{c}\text { Stron- } \\
\text { tium, } \\
\text { dissolved } \\
(\mu \mathrm{g} / \mathrm{L})\end{array}$ \\
\hline \multicolumn{12}{|c|}{ July 2007 Sampling Event } \\
\hline QW1 & $\begin{array}{l}\text { UFA } \\
\end{array}$ & 285125082085301 & 15.1 & E 0.08 & 0.044 & $<0.06$ & 0.001 & 0.044 & 0.09 & 2.2 & 251 \\
\hline QW2 & SA & 285125082085302 & 2.68 & 0.51 & 0.326 & $<0.06$ & 0.002 & 0.015 & $<0.04$ & 8.5 & 274 \\
\hline QW3 & UFA & 285035082075401 & 31.5 & $<0.1$ & 0.029 & $<0.06$ & E 0.001 & 0.095 & 0.09 & 1.4 & 312 \\
\hline QW4 & SA & 285035082075402 & 26.3 & 0.12 & 0.117 & $<0.06$ & E 0.001 & 0.047 & 0.06 & 0.8 & 314 \\
\hline QW5 & UFA & 284811082091301 & 206 & 0.38 & 0.244 & $<0.06$ & $<0.002$ & 0.059 & 0.07 & 5.1 & 6950 \\
\hline QW6 & UFA & 284628082073801 & 1,670 & 0.25 & 0.177 & $<0.06$ & $<0.002$ & 0.039 & $<0.08$ & 1.8 & 10,600 \\
\hline QW7 & UFA & 284628082073802 & 18.9 & $<0.1$ & $<0.02$ & 4.98 & $<0.002$ & 0.042 & 0.05 & 0.5 & 53.4 \\
\hline QW8 & SA & 284628082073803 & 12.7 & E 0.08 & $<0.02$ & 1.18 & $<0.002$ & 0.145 & 0.11 & 1.3 & 87.5 \\
\hline QW9 & UFA & 284528082055201 & 67.3 & $<0.1$ & 0.03 & 0.36 & 0.007 & 0.062 & 0.05 & 1 & 5,900 \\
\hline QW10 & SA & 284456082053102 & 4.8 & $<0.1$ & $<0.02$ & 0.16 & $<0.002$ & 0.072 & 0.06 & 1.2 & 53 \\
\hline QW11 & UFA & 284759082054101 & 0.56 & 0.19 & 0.134 & $<0.06$ & $<0.002$ & 0.142 & 0.12 & 2.9 & 142 \\
\hline QW12 & SA & 284759082054102 & 3.3 & 0.18 & 0.039 & $<0.06$ & $<0.002$ & 0.062 & 0.08 & 2.6 & 59.5 \\
\hline QW18 & SPG & 02312664 & 5.6 & E 0.06 & 0.053 & 0.14 & $<0.002$ & 0.087 & 0.08 & 0.9 & 76.8 \\
\hline QW19 & SPG & 284709082024100 & 6.18 & $<0.1$ & $<0.02$ & 0.34 & $<0.002$ & 0.074 & 0.06 & 0.8 & 86 \\
\hline QW20 & SPG & 284530082034800 & 12.5 & 0.34 & 0.159 & $<0.06$ & $<0.002$ & 0.056 & 0.06 & 2.6 & 142 \\
\hline QW21 & SPG & 284525082040600 & 8.61 & 0.1 & $<0.02$ & E 0.05 & $<0.002$ & 0.045 & 0.05 & 1.1 & 99.6 \\
\hline QW22 & SPG & 284613082070500 & 56.7 & E 0.05 & Е 0.016 & 0.9 & $<0.002$ & 0.052 & 0.05 & 0.6 & 641 \\
\hline QW23 & SW & 284534082054400 & 24.3 & 0.26 & E 0.011 & 0.11 & E 0.001 & 0.052 & 0.06 & 4.9 & 231 \\
\hline QW24 & SW & 02312675 & 56.4 & 0.23 & $<0.02$ & 0.47 & E 0.001 & 0.027 & 0.04 & 2.6 & 330 \\
\hline QW25 & SW & 02312700 & 40.5 & 1 & E 0.013 & $<0.06$ & $<0.002$ & E 0.005 & $<0.04$ & 11.6 & 312 \\
\hline QW26 & SW & 284922082075900 & 38.8 & 0.9 & E 0.011 & $<0.06$ & $<0.002$ & $<0.006$ & $<0.04$ & 10.4 & 295 \\
\hline QW27 & SW & 284630082062700 & 32.4 & 0.47 & 0.02 & $<0.06$ & $<0.002$ & E 0.004 & E 0.02 & 6.3 & 376 \\
\hline QW28 & SW & 284718082070000 & 39.8 & 0.62 & 0.02 & $<0.06$ & $<0.002$ & E 0.003 & E 0.03 & 7.9 & 342 \\
\hline QW29 & SW & 284852082082000 & 37.9 & 0.81 & 0.02 & $<0.06$ & $<0.002$ & E 0.005 & E 0.02 & 11 & 286 \\
\hline \multicolumn{12}{|c|}{ December 2008 through January 2009 Sampling Event } \\
\hline QW1 & UFA & 285125082085301 & 12.4 & 0.12 & 0.044 & $<0.04$ & $<0.002$ & 0.049 & 0.09 & 2.2 & 257 \\
\hline QW2 & SA & 285125082085302 & 6.27 & 0.23 & 0.057 & $<0.04$ & $<0.002$ & 0.112 & 0.12 & 5.9 & 248 \\
\hline QW3 & UFA & 285035082075401 & 27.3 & 0.1 & E 0.014 & $<0.04$ & $<0.002$ & 0.068 & 0.07 & E 0.4 & 310 \\
\hline QW4 & SA & 285035082075402 & 27 & E 0.07 & 0.039 & $<0.04$ & $<0.002$ & 0.046 & 0.06 & 0.5 & 312 \\
\hline QW5 & UFA & 284811082091301 & 183 & 0.45 & 0.249 & $<0.04$ & $<0.002$ & 0.058 & 0.06 & 5.7 & 5970 \\
\hline QW6 & UFA & 284628082073801 & 1,700 & 0.42 & 0.171 & $<0.04$ & $<0.002$ & 0.033 & 0.04 & 5.9 & 11,100 \\
\hline QW7 & UFA & 284628082073802 & 19.7 & $<0.1$ & 0.02 & 4.31 & E 0.001 & 0.042 & 0.05 & E 0.4 & 65.8 \\
\hline QW8 & SA & 284628082073803 & 14.3 & E 0.06 & 0.02 & 1.03 & 0.002 & 0.086 & 0.09 & 0.8 & 75.7 \\
\hline QW9 & UFA & 284528082055201 & 65.1 & E 0.06 & 0.022 & 0.73 & 0.002 & 0.059 & 0.06 & 0.8 & 6150 \\
\hline QW10 & SA & 284456082053102 & 5.44 & $<0.1$ & 0.02 & 0.13 & 0.002 & 0.08 & 0.09 & 0.6 & 58.4 \\
\hline QW11 & UFA & 284759082054101 & $<0.18$ & 0.22 & 0.119 & $<0.04$ & 0.002 & 0.136 & 0.12 & 2.4 & 140 \\
\hline QW12 & SA & 284759082054102 & 1.64 & 0.19 & 0.09 & 0.06 & E 0.001 & 0.174 & 0.21 & 2.4 & 59.3 \\
\hline QW13 & SA & 284734082071201 & 51.8 & 0.2 & 0.021 & 0.17 & 0.036 & 0.462 & 0.44 & 2.5 & 926 \\
\hline QW14 & SA & 284756082061301 & E 0.18 & 4.5 & 3.92 & $<0.04$ & $<0.002$ & 0.058 & 0.18 & 24.6 & 99.1 \\
\hline QW15 & SA & 284922082075901 & 62.1 & 0.13 & 0.075 & $<0.04$ & $<0.002$ & 0.049 & 0.05 & 1.8 & 950 \\
\hline QW16 & LFA & 284949082000501 & 29.5 & 0.11 & 0.059 & $<0.04$ & $<0.002$ & 0.03 & E 0.04 & 0.9 & 758 \\
\hline QW17 & UFA & 284949082000502 & 2.15 & 0.14 & 0.081 & $<0.04$ & $<0.002$ & 0.081 & 0.09 & 1.1 & 122 \\
\hline QW18 & SPG & 02312664 & 6.33 & 0.11 & 0.02 & 0.59 & 0.067 & 0.078 & 0.08 & 1.6 & 72.6 \\
\hline QW19 & SPG & 284709082024100 & 6.71 & $<0.1$ & 0.02 & 0.68 & $<0.004$ & 0.078 & 0.08 & 0.8 & 82.2 \\
\hline QW21 & SPG & 284525082040600 & 9.63 & E 0.09 & 0.02 & 0.22 & 0.014 & 0.044 & 0.05 & 0.7 & 102 \\
\hline QW22 & SPG & 284613082070500 & 56 & E 0.06 & 0.02 & 1.04 & E 0.002 & 0.053 & 0.06 & 0.7 & 697 \\
\hline QW23 & SW & 284534082054400 & 7.57 & 0.35 & E 0.014 & 0.08 & E 0.001 & 0.045 & 0.05 & 7.1 & 184 \\
\hline QW24 & SW & 02312675 & 11.9 & 0.38 & E 0.012 & 0.64 & 0.002 & 0.028 & E 0.04 & 7.5 & 294 \\
\hline QW25 & SW & 02312700 & 20.8 & 0.82 & 0.02 & $<0.04$ & $<0.002$ & E 0.005 & $<0.04$ & 14.1 & 381 \\
\hline QW26 & SW & 284922082075900 & 18.9 & 0.59 & 0.02 & $<0.04$ & $<0.002$ & E 0.006 & $<0.04$ & 12.1 & 345 \\
\hline QW27 & SW & 284630082062700 & 20.9 & 0.64 & 0.02 & $<0.04$ & $<0.002$ & E 0.005 & $<0.04$ & 13.5 & 345 \\
\hline
\end{tabular}


Publishing support provided by:

Ft. Lauderdale Publishing Service Center

Technical editing by Jane R. Eggleston and Michael Deacon

Illustrations by Kimberly A. Swidarski

Layout and design by Twila Darden Wilson 
